\title{
INFORMATION ON HYDROLOGIC AND PHYSICAL PROPERTIES OF WATER TO ASSESS TRANSIENT HYDROLOGY OF THE MILFORD-SOUHEGAN GLACIAL-DRIFT AQUIFER, MILFORD, NEW HAMPSHIRE
}

By Philip T. Harte, Robert J. Flynn, Richard G. Kiah, Timothy Severance, and Michael F. Coakley

U.S. GEOLOGICAL SURVEY

Open-File Report 97-414

Prepared in cooperation with the U.S. ENVIRONMENTAL PROTECTION AGENCY REGION I, WASTE MANAGEMENT DIVISION

Pembroke, New Hampshire 1997

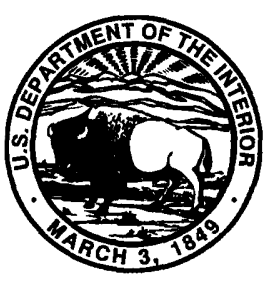




\title{
U.S. DEPARTMENT OF THE INTERIOR
}

\author{
BRUCE BABBITT, Secretary
}

\author{
U.S. GEOLOGICAL SURVEY \\ Gordon P. Eaton, Director
}

For additional information write to:

Chief, NH-VT District

U.S. Geological Survey

361 Commerce Way

Pembroke, NH 03275
Copies of this report can be purchased from:

U.S. Geological Survey

Branch of Information Services

Box 25425

Denver, Co 80225-0286 


\section{CONTENTS}

Page

Abstract .................... 1

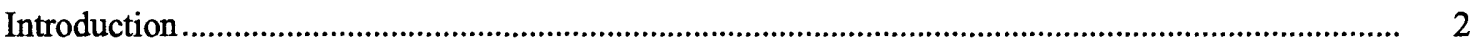

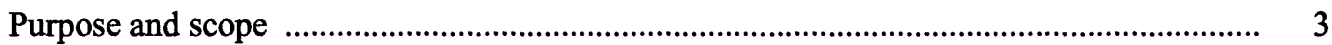

Description of study area ............................................................................................. 5

Previous investigations ....................................................................................... 5

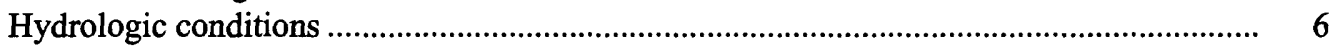

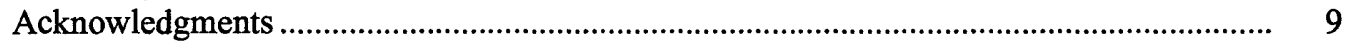

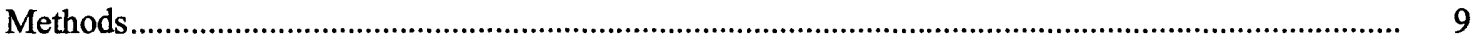

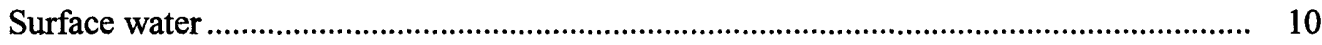

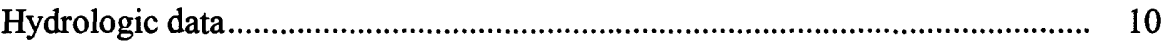

Physical data ............................................................................................ 13

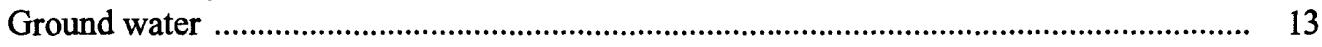

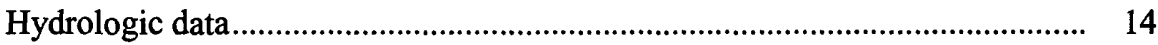

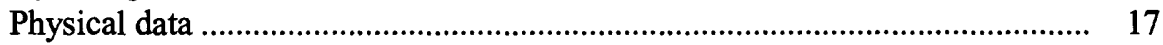

Surface-water and ground-water interactions............................................................ $\quad 17$

Results of hydrologic data collection ............................................................................................... 17

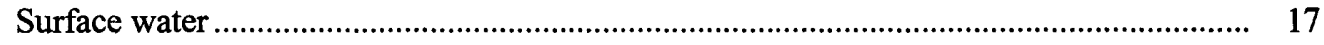

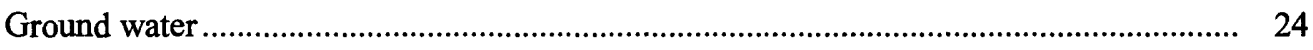

Surface-water and ground-water interactions.......................................................... 31

Results of physical water-property data collection .................................................................. 36

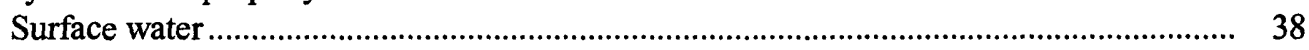

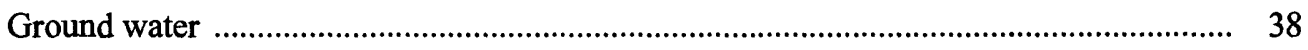

Surface-water and ground-water interactions........................................................ 41

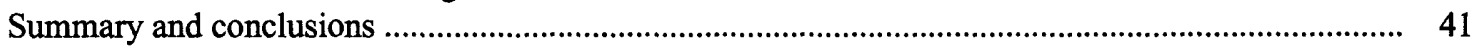

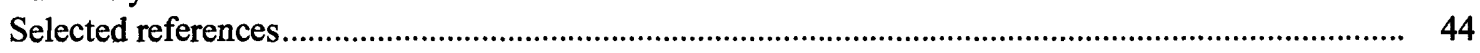

Appendix 1. Information on well construction for selected wells in Milford,

New Hampshire

Appendix 2. River stage from staff gages on the Souhegan River and tributaries

in Milford, New Hampshire ................................................................................................ 56

Appendix 3. Ground-water levels from biweekly measurements of wells,

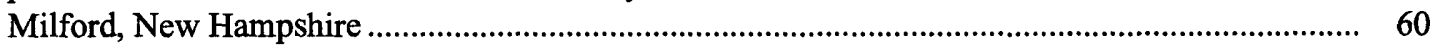

Appendix 4. Graphs of ground-water levels from biweekly measurements of wells,

Milford, New Hampshire. ................................................................................................................. 78

Appendix 5. Ground-water levels from synoptic measurements of wells, Milford,

New Hampshire

Appendix 6. Surface-water and ground-water hydraulic gradients determined from

wells in the glacial-drift aquifer and staff gages in the Souhegan River, Milford,

New Hampshire

\section{FIGURES}

\section{(Plate is in envelope in back of report)}

Plate 1. Map showing the locations of ground-water wells in the Milford-Souhegan glacial-drift aquifer, Milford, New Hampshire. 
1. Map showing location of the Milford-Souhegan glacial-drift aquifer, Milford, New Hampshire

2. Map showing extent of contaminant plume of total volatile organic compounds in the Milford-Souhegan glacial-drift aquifer, Milford, New Hampshire.

3. Ground-water levels from a long-term observation well (MI-18; well number 29), Milford, New Hampshire.

4. Map showing location of streamflow-gaging stations, Milford, New Hampshire

5. Diagram showing construction and instrumentation of continuous streamflow gaging station, Milford, New Hampshire

6. Map showing location of continuous physical water-property and ground-water observation wells, Milford, New Hampshire

7. Map showing location of biweekly measured ground-water level wells, Milford, New Hampshire

8. Diagram showing construction and instrumentation of continuous ground-water observation well

9. Graphs showing river stage and riverbed water levels at streamflow-gaging stations WLR-1, WLR-5, and WLR-4, Milford, New Hampshire.

10. Graph showing daily mean discharge for streamflow-gaging stations WLR and WLR-5 Milford, New Hampshire

11. Graph showing change in streamflow discharge in the Souhegan River in Milford, New Hampshire between: (a) WLR-1 and P-2, (b) WLR-5 and station 39, and (c) streamflow discharge at WLR-5

12. Graph showing change in streamflow discharge in the discharge ditch in Milford, New Hampshire between (a) WLR-2 and WLR-3, (b) WLR-3 and WLR-4, and (c) streamflow discharge at WLR-3.

13. Map showing patterns of change in streamflow discharge in Milford, New Hampshire from:

(a) low-flow conditions, October 1988

(b) medium-flow conditions, October 1990

(c) high-flow conditions, April 1994.

14. Graphs showing continuous daily mean ground-water levels for wells P-1, P-2, MI-18, MW-2A, and MW-5B, Milford, New Hampshire

15. Graphs showing apparent ground-water hydraulic gradients along transects in the Milford-Souhegan glacial drift aquifer, Milford, New Hampshire.

16. Map showing triangular grouping of biweekly measured wells for determination of true ground-water-hydraulic gradients, Milford, New Hampshire.

17. Maps showing contours of the water-table surface in the Milford-Souhegan glacial-drift aquifer, Milford, New Hampshire for:
(a) October 1988
(b) October 1990
(c) April 1994
18. Graph showing continuous daily mean river stage and riverbed water levels
for streamflow-gaging stations WLR-1, and ground-water level for well P-1, Milford, New Hampshire

19. Graph showing magnitude and direction of hydraulic gradients between surface and ground waters at river gages on the Souhegan River and adjacent ground-water level measurement wells, Milford, New Hampshire

20. Graph showing daily mean specific conductance and temperature of waters for streamflow-gaging stations WLR-1, WLR-4, and WLR-5, Milford, New Hampshire.

21. Graph showing daily mean specific conductance and temperature of waters for streamflow-gaging station WLR-1 and observation wells P-1, P-2, and MW-2A, Milford, New Hampshire 
1. Ground-water withdrawals from currently used (1997) commercial and industrial water-supply wells, Milford, New Hampshire.

2. Monthly precipitation for $1994-95$ and comparison to long-term monthly averages, Milford, New Hampshire

3. Comparison of ground-water levels from a long-term observation well in Milford (MI-18; well number 29) with precipitation and ground-water withdrawals from nearby wells, Milford, New Hampshire.

4. Streamflow-duration data for daily discharges at three reference streamflowgaging stations for days when measurements were taken in Milford, New Hampshire.

5. Streamflow discharge from monthly measurements at selected streamflowgaging stations, Milford, New Hampshire

6. Streamflow measurements from high-flow synoptic gaging stations, April 1994, Milford, New Hampshire.

7. Ground-water-level fluctuations for wells measured biweekly (June 1994-June 1995), Milford, New Hampshire.

8. Summary statistics on direction of maximum ground-water-hydraulic gradients, and magnitude of slope of gradient from triangular grouping of wells (June 1994-1995), Milford, New Hampshire.

9. Summary of differences in ground-water levels between synoptic events in October 1988, October 1990, and April 1994, Milford, New Hampshire

10. Difference between October 1990 synoptic ground-water levels and the arithmetic mean of ground-water levels from biweekly measurements (June 1994-June 1995), Milford, New Hampshire. 


\section{CONVERSION FACTORS}

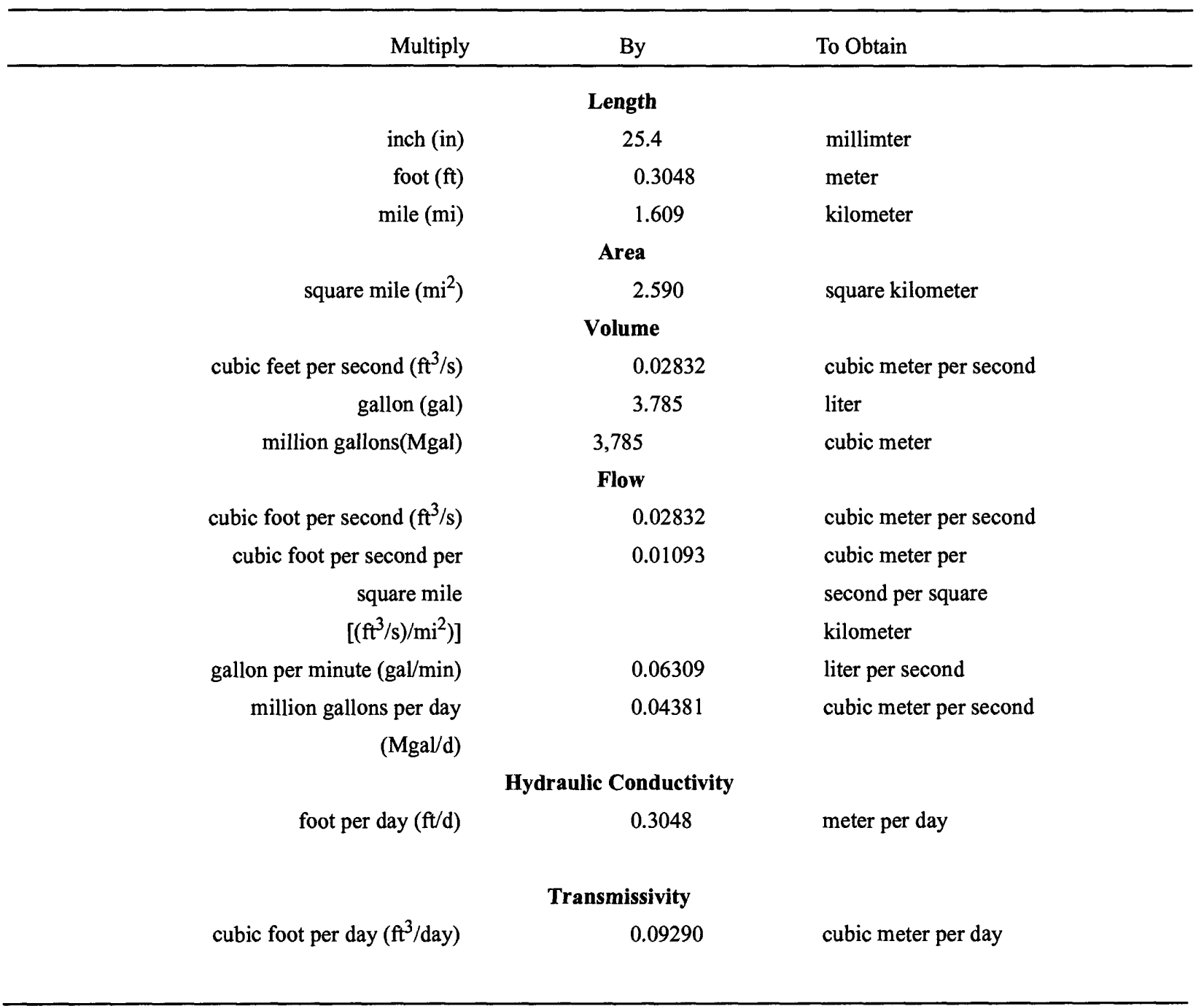

Sea Level: In this report, "sea level" refers to the National Geodetic Vertical Datum of 1929--a geodetic datum derived from a general adjustment of the first-order level nets of both the United States and Canada, formerly called Sea Level Datum of 1929. Abbreviated water-quality units used in this report: Specific conductance is measured in microsiemens per centimeter $(\mu \mathrm{S} / \mathrm{cm})$ at 25 degrees Celsius $\left({ }^{\circ} \mathrm{C}\right)$. Specific conductance is related to the type and concentration of ions in solution and can be used for approximating the dissolved-solids content of water. Commonly, the concentration of dissolved solids (in milligrams per liter) is about 65 percent of the specific conductance (in microsiemens). Water temperature in degrees Celsius (C) can be converted to degrees Fahrenheit $(\mathrm{F})$ by use of the following equation:

${ }^{\circ} \mathrm{F}=1.8\left({ }^{\circ} \mathrm{C}\right)+32$ 


\title{
INFORMATION ON HYDROLOGIC AND PHYSICAL PROPERTIES OF WATER TO ASSESS TRANSIENT HYDROLOGY OF THE MILFORD-SOUHEGAN GLACIAL- DRIFT AQUIFER, MILFORD, NEW HAMPSHIRE
}

\author{
By Philip T. Harte, Robert J. Flynn, Richard Kiah, \\ Timothy Severance, and Michael F. Coakley
}

\begin{abstract}
The Milford-Souhegan glacial-drift (MSGD) aquifer, in southcentral New Hampshire, is an important source of industrial, commercial, and domestic water use providing more than 2.7 million gallons of water per day in 1994. A large volatile organic contaminant plume (approximately 0.5 square miles in area) covers the southwestern half of the MSGD aquifer and threatens present ground-water usage. As a result, the southwestern half of the MSGD aquifer has been designated a Superfund site and named after a former municipal water-supply well (Savage Well) that was discontinued because of contamination.
\end{abstract}

A 3-year study by the U.S. Geological Survey and the U.S. Environmental Protection Agency began in January 1994 to examine the temporal variability of ground-water flow in the contaminant plume and adjacent areas of the southwestern part of the MSGD aquifer. This report summarizes data from April 1994 to September 1995 in support of this effort.

Data presented in this report include continuous measurements of river stage at 3 gaging stations and periodic measurements of river stage at 5 additional stations; one set of streamflow discharge measurements at up to 20 sites during high-flow conditions, called the high-flow synoptic, monthly streamflow measurements at up to 8 sites; computation of continuous streamflow at 3 stations; biweekly measurements of ground-water levels at 87 wells; continuous measurements of groundwater levels at 5 wells; and ground-water levels from the high-flow synoptic at 115 wells. Physical data (specific conductance and temperature) were collected continuously at five sites to reveal surface- and ground-water interactions. Collectively, these data were assessed for temporal and spatial variations and also compared to two data sets from previous U.S. Geological Survey studies of the aquifer.

The aquifer is typical of other permeable glacial-drift aquifers in that a good hydraulic connection is present between surface and ground waters, which allows rapid exchange of surface and ground waters. Data from this study on river stages, riverbed water levels, and ground-water levels adjacent to rivers showed fluctuations similar in magnitude and timing. River stages and ground-water levels fluctuated by about 5 feet in most areas not affected by ground-water withdrawals. Physical data 
showed trends in specific conductance that were similar at river-gaging stations and at adjacent wells that were unaffected by chemicals from road salt. Physical data also showed that water temperatures were largely affected by thermal conduction and ground-water temperatures lagged behind surface-water temperatures by 3 to 6 months. This lag in water temperatures allows for identification of ground-water discharge areas to rivers.

Large seasonal changes in ground-water flow occurred near rivers and areas of large groundwater withdrawals. Near the upstream reaches of the Souhegan River, which is the source of the large tetrachloroethylene (PCE) volatile organic plume, the river recharges the aquifer and seasonal river leakage roughly varied by one order of magnitude with a maximum leakage of 30 cubic feet per second. In the same area, surface and groundwater gradients between the river and aquifer varied by a factor of four, the direction of maximum ground-water gradients varied by 51 degrees, and the magnitudes of maximum ground-water gradients varied by 45 percent. Near the confluence of two rivers (Souhegan River and Purgatory Brook), maximum ground-water gradients varied in direction by 144 degrees, indicating that groundwater discharge oscillated between the Souhegan River and Purgatory Brook. Near the State Fish Hatchery wells, withdrawing about $2.3 \mathrm{Mgal} / \mathrm{d}$, ground-water gradients changed by a factor of four as the result of seasonal trends in ground-water recharge and withdrawals.

Transient seasonal conditions, which cause changes in ground-water hydraulic gradients through the aquifer, partly explain the lateral distribution of contaminants found in the aquifer. Ground-water hydraulic gradients along the longitudinal axis of the plume showed a fairly constant gradient that averaged 0.0747 foot per foot with a standard deviation of 0.0014 . Magnitudes of ground-water hydraulic gradients transverse to the plume averaged 0.0176 foot per foot with a standard deviation of 0.0027 , almost twice the standard deviation of the longitudinal gradient.
Physical data collected at three river-gaging stations and three wells open to the aquifer showed that specific conductance was highest at the discharge ditch ranging from 300 to 600 microsiemens per centimeter $(\mu \mathrm{S} / \mathrm{cm})$ at 25 degrees Celsius $\left({ }^{\circ} \mathrm{C}\right)$ and the least in samples from wells ranging from 75 to $200 \mu \mathrm{S} / \mathrm{cm}$. Specific conductances were highest in winter and spring and lowest in the fall. Water temperatures varied from 0 to $24^{\circ} \mathrm{C}$ at the three river-gaging stations and from 8 to $16^{\circ} \mathrm{C}$ at the three wells.

\section{INTRODUCTION}

The Milford-Souhegan glacial-drift (MSGD) aquifer, in southcentral New Hampshire (fig. 1), is an important source of industrial, commercial, and domestic water use accounting for more than $2.7 \mathrm{Mgal} / \mathrm{d}$ in 1994 . Until it was found to contain high concentrations of volatile organic compounds (VOC's) in the early 1980's, the MSGD aquifer was also an important source of drinking water from two former municipal supply wells (the Savage and Keyes wells). Subsequent to contamination, local, State and Federal agencies initiated geohydrologic studies to characterize this glacial-drift river-valley aquifer and delineate the extent of contamination. In 1989, a large VOC plume was found to cover the southwestern half of the MSGD aquifer (HMM Associates, 1989). In 1997, the large VOC plume still threatens present ground-water usage at State and commercial fish hatcheries (fig. 2). The primary source of contamination appears to be a discontinued tool company (fig. 2) that discharged wastes into the subsurface for many years until the early 1980's (HMM Associates, 1989). Although discharges have ceased, the underlying sediments, and the immersible pockets of VOC's beneath the site continue to contaminate the ground water flowing across the area.

Although some information is available on contaminant distribution, general patterns of groundwater flow and preliminary estimates of bulk-fluid-flow data are insufficient to be used to design effective remedial schemes to reduce or eliminate the contaminant plume. Previous data-collection efforts in the MSGD aquifer have not adequately addressed the variability of hydrologic conditions on the basis of seasonal and annual differences in ground-water 


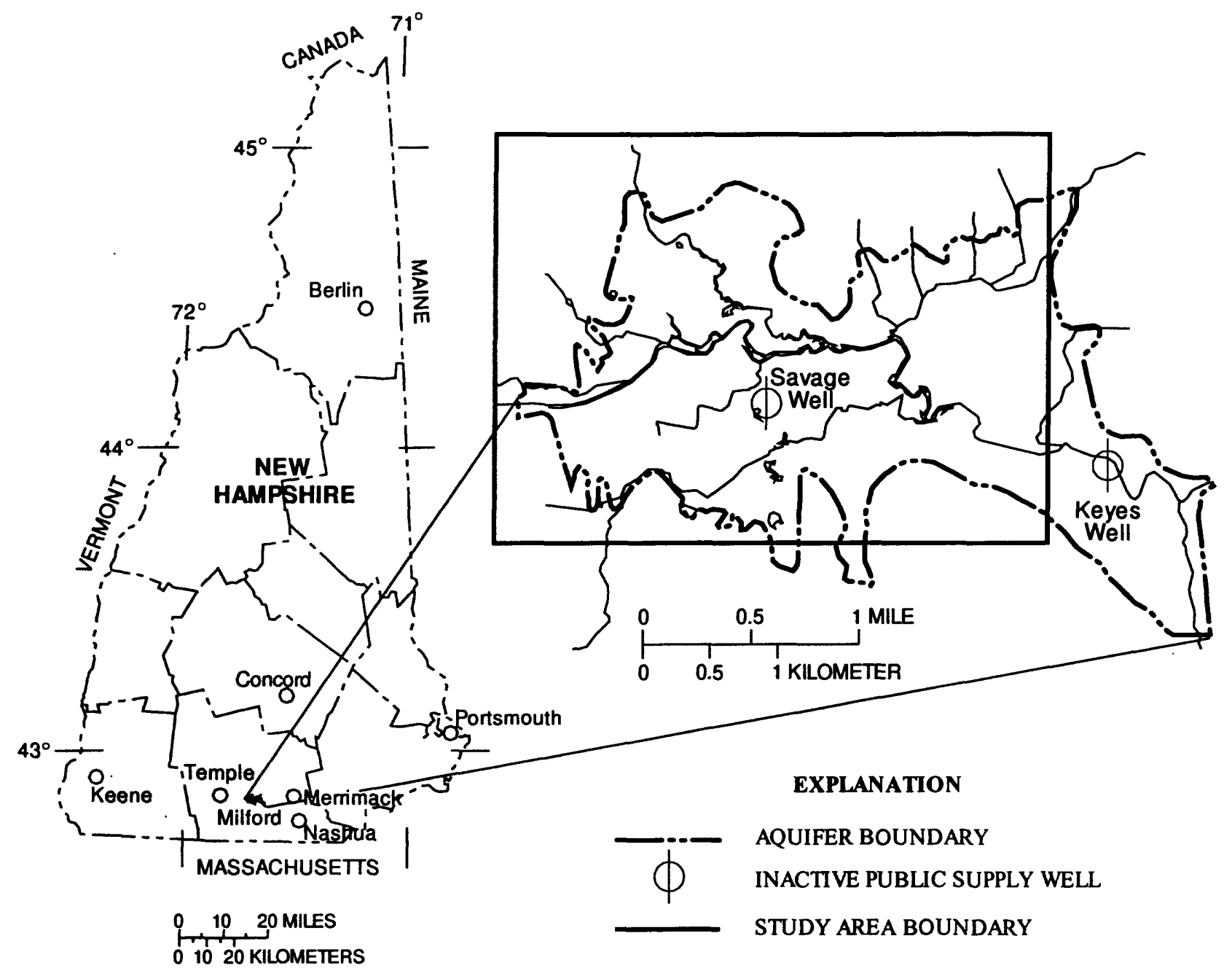

Flgure 1. Location of the Milford-Souhegan glacial-drift aquifer, Milford, New Hampshire.

recharge and discharge. Previous data on ground-water levels, river stage, and streamflow were collected primarily during low recharge periods and over short intervals of time without consideration to seasonal, annual, and long-term conditions. A cost-effective remedial design requires information on the transient nature of the ground-water system to improve rate estimates of contaminant transport, and to assess the feasibility of pump-and-treat technology.

A 3-year study by the U.S. Geological Survey (USGS) and the U.S. Environmental Protection Agency (USEPA) began in January 1994 to increase the understanding of transient hydrologic conditions in the aquifer. The primary objective of this study is to evaluate the effect of temporal changes in recharge, discharge, and ground-water withdrawals on contaminant transport. Specific objectives include:
(1) Determine the temporal variability of ground-water-flow directions.

(2) Determine the temporal variability of surface and ground-water interactions between the Souhegan River and the glacial-drift aquifer.

(3) Construct detailed numerical ground-water-flow models to use in remedial design.

(4) Identify flow paths to pumped wells by use of ground-water-flow models and chemical data collected in the field.

\section{Purpose and Scope}

This report summarizes the results of surface- and ground-water data collected from April 1994 to September 1995 and describes the temporal variability of hydrologic conditions in the MSGD aquifer. 


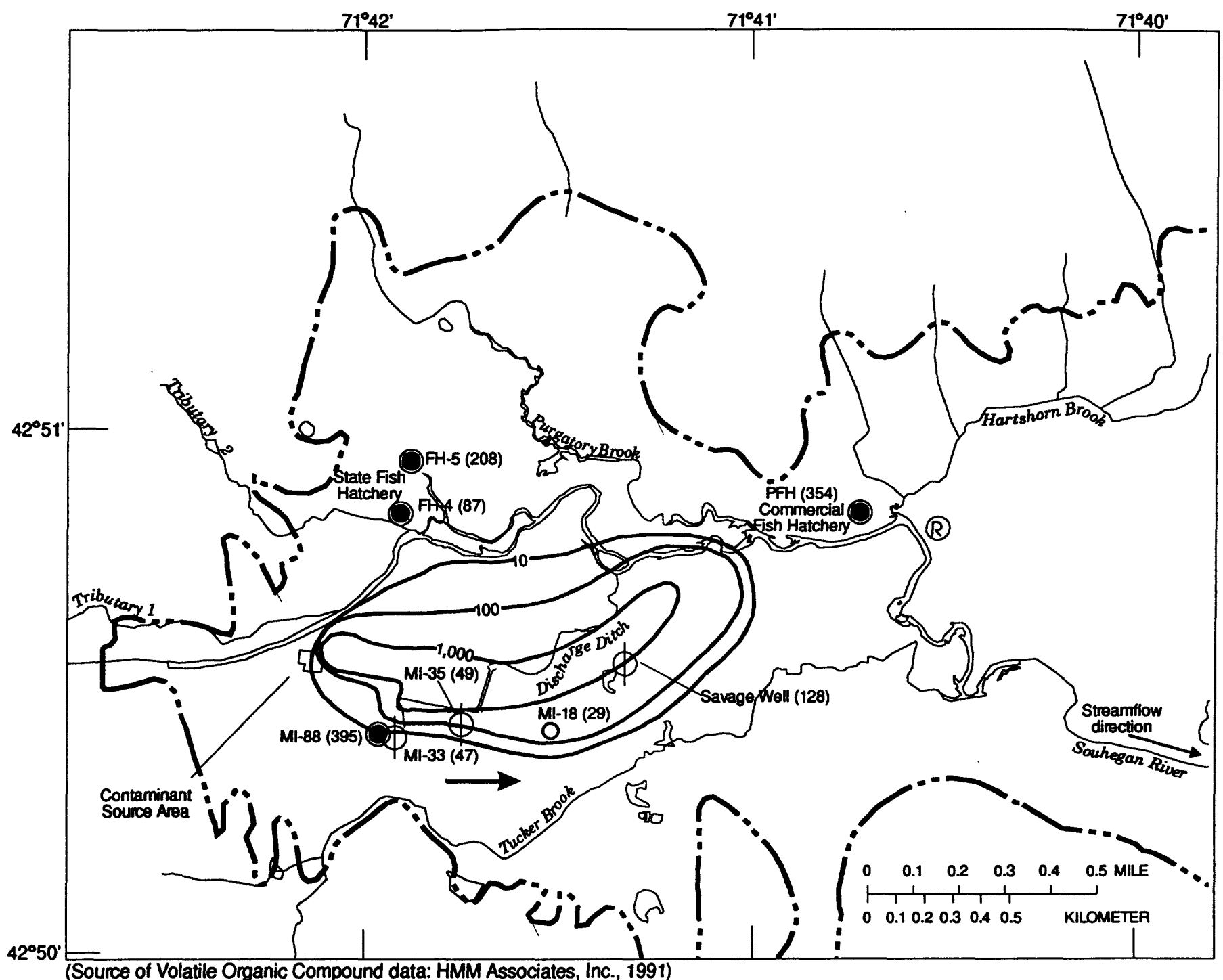

(Source of Volatile Organic Compound data: HMM Associates, Inc., 1991) (Data collected between January 1989 and January 1990)

\section{EXPLANATION}
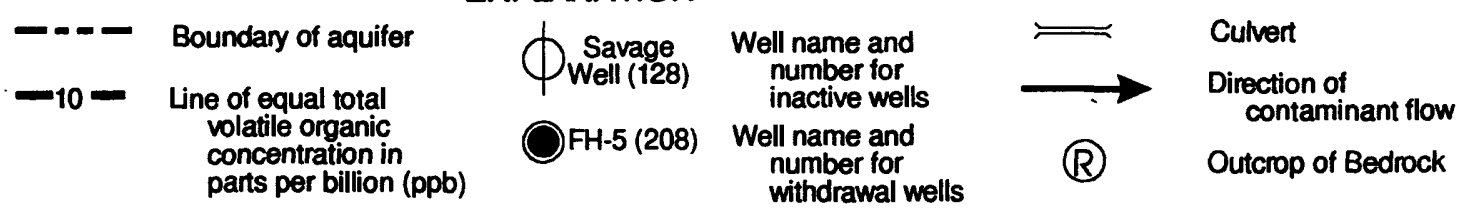

Flgure 2. Extent of contaminant plume of total volatile organic compounds in the the Mllford-Souhegan glacial-drift aquifer, Milford, New Hampshire.

However, most data were collected from April 1994 to July 1995. Data presented in this report include continuous measurements of river stage and discharge at 3 gaging stations and periodic measurements of river stage at 5 stations, streamflow discharge measurements at 20 sites during high-flow conditions (called a highflow synoptic), monthly streamflow measurements at 8 sites, biweekly measurements of ground-water levels at
87 wells, continuous measurements of ground-water levels at 5 wells, and a single measurement of groundwater levels at 115 wells during the high-flow synoptic. Physical data (specific conductance and temperature) were collected continuously at five sites to identify patterns of surface- and ground-water interaction.

Data from this study are compared to data previously collected to reference hydrologic conditions 
during 1994 and 1995 to long-term conditions. Data referenced from previous works include streamflow and ground-water levels collected from 1988 to 1990 by the USGS.

\section{Description of Study Area}

The focus of data collection and study is the delineated western part of the MSGD aquifer (fig. 1), which contains the contaminant plume (fig. 2). Because the MSGD extends beyond the western part of the Milford-Souhegan River Valley, however, selected data were also collected in the eastern part of the valley. This section describes the characteristics of the entire valley with an emphasis on the western part.

The MSGD aquifer is defined as the entire sequence of unsaturated and saturated alluvium, glacial drift, and other unconsolidated deposits above the bedrock surface in the Souhegan River valley in Milford, New Hampshire (fig. 1). The aquifer consists primarily of stratified sand and gravel with some basal till and is overlain in places by recent alluvium. The maximum saturated thickness of the aquifer exceeds $100 \mathrm{ft}$ on the eastern side, but generally ranges from 0 to $60 \mathrm{ft}$. Laterally, the aquifer is bounded by till-covered bedrock uplands.

The Souhegan River valley in the Milford area slopes gently by $12 \mathrm{ft} / \mathrm{mi}$ along the river. Land-surface elevations range from 230 to $280 \mathrm{ft}$ in the area. The land is drained by the Souhegan River and its tributaries, including Tucker, Purgatory, Great , and Hartshorn Brooks, and a number of small, unnamed streams. A discharge ditch drains processed waters from several manufacturing companies in the southwestern part of the study area.

Land use is predominantly industrial in the southwestern part of the study area, agricultural in the central and northwestern areas, and residential to commercial elsewhere. The contaminant plume underlies a large agricultural and industrial section in in the center of the study area (fig. 2).

Ground-water withdrawals are primarily used for commercial and industrial purposes (table 1). Withdrawal wells include two wells for the State Fish Hatchery in the northwestern part of the study area (well numbers 87 and 208; fig. 2), a well at a commercial fish hatchery in the central to eastern part of the study area (well number 354; fig. 2), and a well for an industrial and manufacturing complex in the southwestern part of the study area (well number 395; fig. 2).

\section{Previous Investigations}

Previous studies of the MSGD aquifer include a surficial map of geologic deposits (Koteff, 1970), and work done to characterize the subsurface geology and contaminant distribution through test drilling, waterquality sampling, and surface geophysical surveys by the New Hampshire Water Supply and Pollution Control Division of the New Hampshire Department of Environmental Services (NHDES), (1985), and HMM Associates (1989, 1991).

Previous information on hydrologic conditions has been limited to discrete sampling events that do not show the temporal variability of hydrologic conditions, (HMM Associates, 1989, 1991; Harte and Mack, 1992; Olimpio and Harte, 1994). Harte and Mack (1992)

Table 1. Ground-water withdrawals from currently used (1997) commercial and industrial water-supply wells, Milford, New Hampshire

\begin{tabular}{lcccc}
\hline \multicolumn{1}{c}{ Weli name } & $\begin{array}{c}\text { Well number } \\
\text { used in this } \\
\text { report } \\
\text { (plate 1) }\end{array}$ & $\begin{array}{c}\text { Depth of well, in } \\
\text { feet beiow land } \\
\text { surface }\end{array}$ & $\begin{array}{c}\text { Average dally } \\
\text { withdrawals in } \\
\text { 1994, in milions of } \\
\text { galions per day }\end{array}$ & $\begin{array}{c}\text { Average dally } \\
\text { withdrawals In } \\
\text { 1995, in milions of } \\
\text { galions per day }\end{array}$ \\
\hline $\begin{array}{l}\text { State of New Hampshire Fish Hatchery (well } \\
\text { FH-5) }\end{array}$ & 208 & 65 & 1.05 & 1.10 \\
$\begin{array}{l}\text { State of New Hampshire Fish Hatchery well } \\
\text { (FH-4) }\end{array}$ & 87 & 42 & 1.26 & 1.19 \\
$\begin{array}{l}\text { Industriai production well (MI-88) } \\
\text { Industrial production well (MI-33) }\end{array}$ & 395 & 42 & .25 & .25 \\
Commercial Fish Hatchery well (PFH) & 47 & 60 & 0 & 0 \\
\hline
\end{tabular}


showed that selected reaches of the Souhegan River and its tributaries interact with the ground-water system by recharging the MSGD aquifer. Other stream reaches receive discharge from the ground-water system. Understanding the distribution of recharging and discharging stream reaches is important in determining the flow and fate of contaminants moving with ground water. Although some information on the patterns of recharge and discharge were available prior to this study, it was not known if these patterns varied with time.

Investigations of ground-water quality focused on describing the extent of contaminants in the subsurface during synoptic events (HMM Associates, 1989, 1991). The distribution of contaminants from one such synoptic event in 1989 is shown in fig. 2. Temporal changes in water chemistry and physical water properties over an annual hydrologic cycle have not been described.

\section{Hydrologic Conditions}

Monthly precipitation totals for 1994 and 1995 , collected by the National Oceanic and Atmospheric Administration climatological station in Milford, indicate annual precipitation in 1994 was 2.48 in. above long-term averages and annual precipitation in 1995 was 2.99 in. below long-term averages (table 2). Streamflow and ground-water levels for the region of southern New Hampshire were also above average in 1994 but below average in 1995 (table 2) (Toppin and others, 1994; Hammond and others, 1995).

Above-average air temperatures in December 1994 and the winter of 1995 caused atypically high streamflow and ground-water levels, which are discussed in the "Results of Hydrologic Data Collection" section of this report. For example, aboveaverage streamflow and ground-water levels in December 1994 were caused by unseasonably warm temperatures and runoff from snowmelt and rain. Later during the spring of 1995, the lack of an appreciable snowpack resulted in below-average streamflow and ground-water levels.

A comparison of noncontinuous monthly groundwater levels in the USGS long-term observation well MI-18 in Milford (well number 29 in this report; identified as MOW-36 in a previous report by Harte and Mack, 1992) revealed that the arithmetic-mean water level ( $7.16 \mathrm{ft}$ below the land surface) for 1994-95 was $1.19 \mathrm{ft}$ above the long-term arithmetic-mean water level

Table 2. Monthly precipitation for 1994 and 1995, and comparison to long-term monthly averages, Milford, New Hampshire

[Values in inches from climatological station at Milford. Source of data is from the National Oceanic and Atmospheric Administration (NOAA). Average precipitation based on records from 1951-80]

\begin{tabular}{lcclcc}
\hline $\begin{array}{c}\text { Month In } \\
1994\end{array}$ & Preclpltation & $\begin{array}{c}\text { Deviation } \\
\text { from average } \\
\text { precipitation }\end{array}$ & $\begin{array}{c}\text { Month in } \\
\text { 1995 }\end{array}$ & Preclpitation & $\begin{array}{c}\text { Devlation from } \\
\text { average } \\
\text { precipltation }\end{array}$ \\
\hline January & 4.95 & 1.16 & January & 3.82 & 0.03 \\
February & 1.54 & -1.73 & February & 2.99 & -.28 \\
March & 5.99 & 2.04 & March & 1.97 & -1.98 \\
April & 2.54 & -1.18 & April & 2.03 & -1.69 \\
May & 5.07 & 1.43 & May & 3.23 & -.41 \\
June & 1.77 & -1.77 & June & 1.78 & -1.76 \\
July & 4.33 & 1.20 & July & 3.53 & .40 \\
August & 4.89 & 1.21 & August & 2.35 & -1.33 \\
September & 5.82 & 2.29 & September & 2.53 & -1.00 \\
October & .61 & -3.21 & October & 8.23 & 4.41 \\
November & 3.87 & -.62 & November & 6.74 & 2.25 \\
December & 6.10 & 1.66 & December & 2.81 & -1.63 \\
Total & 47.48 & 2.48 & Total & 42.01 & -2.99 \\
\hline
\end{tabular}


Table 3. Comparison of ground-water levels from long-term monitoring well MI-18 (well number 29) with precipitation and ground-water withdrawals from nearby wells, Milford, New Hampshire

[Location of well MI-18 (well number 29) is found on plate I; Mgal/d, million gallons per day]

\begin{tabular}{ccccc}
\hline $\begin{array}{c}\text { Period of } \\
\text { comparison }\end{array}$ & $\begin{array}{c}\text { Average depth of water levels } \\
\text { for period of record, in feet } \\
\text { below land surface }\end{array}$ & $\begin{array}{c}\text { Standard deviation } \\
\text { of water levels, } \\
\text { in feet }\end{array}$ & $\begin{array}{c}\text { Average annual } \\
\text { precipltation for } \\
\text { period of record, in } \\
\text { inches }\end{array}$ & $\begin{array}{c}\text { Average dally } \\
\text { ground-water } \\
\text { withdrawals for } \\
\text { period of record, in } \\
\text { Mgal/d }\end{array}$ \\
\hline $1962-65$ & 9.10 & 1.55 & 31.79 & 0.209 \\
$1966-73$ & 8.84 & 1.31 & 45.50 & .570 \\
$1974-83$ & 8.37 & 1.20 & 47.63 & .720 \\
$1984-89$ & 7.66 & .75 & 47.83 & .512 \\
$1990-95$ & 6.98 & .68 & 48.25 & .246 \\
\hline
\end{tabular}

for the period of record (1962-95). However, water levels in this well were probably affected by historical variations of ground-water withdrawals in the aquifer, which have decreased since 1984.

Withdrawal effects on water-level changes are noticeable when comparing pre- and post-1984 water levels (fig. 3 and table 3). Long-term water levels for MI-18 are shown in figure 3. A comparison of historical mean water levels, ground-water withdrawals, and precipitation is given in table 3 for periods corresponding to historical changes in groundwater withdrawals in the aquifer. The grouping of water levels by withdrawals allows for a simple comparison of the effects of precipitation and withdrawals on water levels. During 1962-65 and 1990-95, the amount of withdrawals were similar but average annual precipitation was different. Average annual precipitaion was approximately 50 percent greater in 1990-95 than in 1962-65 and, as a result, average water levels were $2.12 \mathrm{ft}$ higher in 1990-95 than water levels in 1962-65. In contrast, 1974-83 and 198489 had similar average annual precipitation but different withdrawals. Average daily ground-water withdrawals were approximately 34 percent greater in 1974-83 than in 19-1989 and, as a result, average water levels were $0.71 \mathrm{ft}$ lower in 1974-83 than in 1984-89.

A two-sample Wilcoxon rank sum test (Wilcoxon, 1945), also called the Mann-Whitney test, was used to

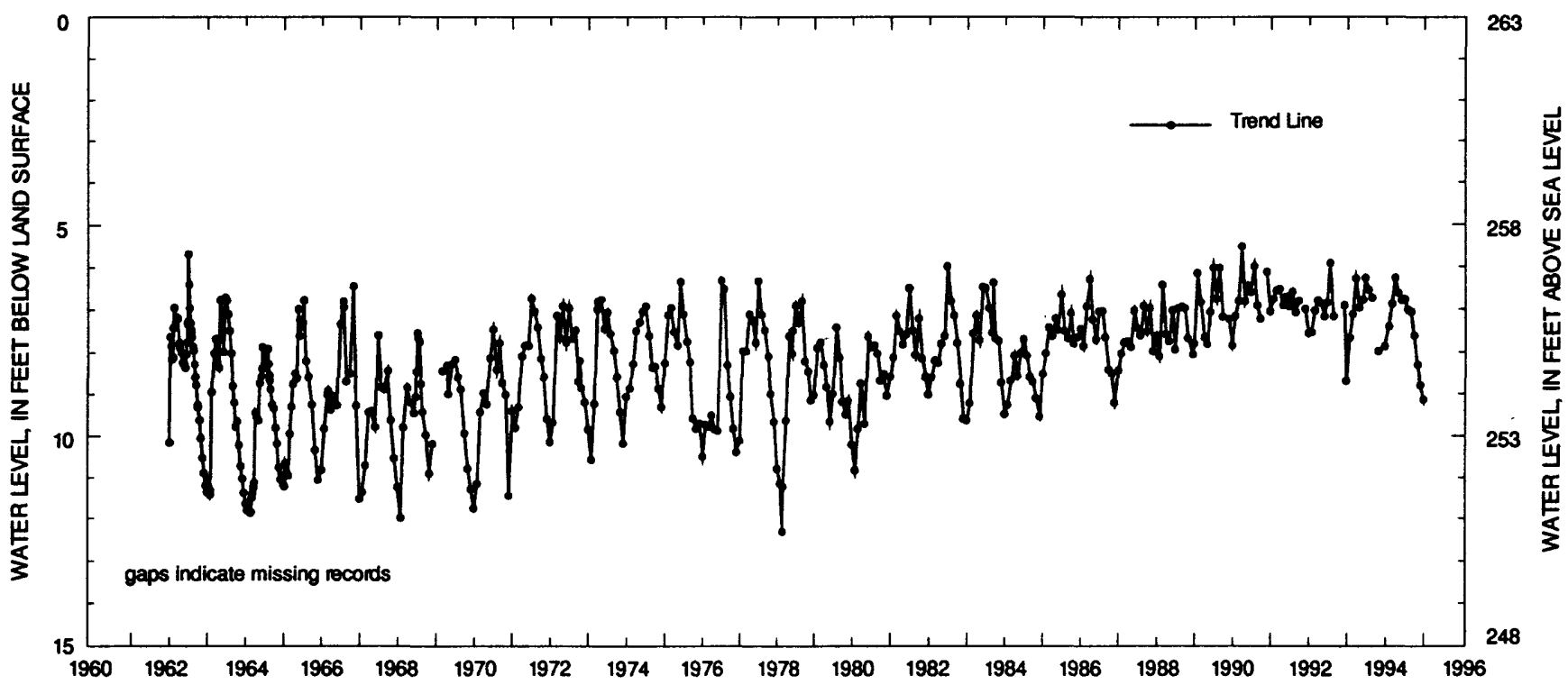

Figure 3. Ground-water levels from a long-term observation well (MI-18; well number 29), Milford, New Hampshire. 
determine the significance of differences in the 1974-83 and 1984-89 ground-water levels. Test results indicate water levels are significantly different between the 1974-83 and $1984-89$ periods at a 99.98 percent confidence level, which indicates that withdrawals affect ground-water levels in the well.

In order to describe hydrologic conditions present during the 1994-95 study, and during periods when data were collected in Milford for previous USGS studies (Harte and Mack, 1992; Olimpio and Harte, 1994), measurements taken at Milford were referenced to streamflow-duration data from three long-term (greater than 20 years) streamflow gaging stations located outside of the study area (table 4). This technique was used because (1) ground-water levels from the longterm observation well MI- 18 appear to be affected by withdrawals, and (2) streamflow gaging on the Souhegan River in Milford has not been done long enough to generate reliable streamflow durations. Referenced gaging stations are on the Souhegan River at Merrimack, N.H. (171 $\mathrm{mi}^{2}$ drainage area), Stony Brook near Temple, N.H. (3.6 $\mathrm{mi}^{2}$ drainage area), and the Soucook River near Concord, N.H. $\left(81.9 \mathrm{mi}^{2}\right.$ drainage area). Hydrogeologic conditions at these stations are diverse enough to include similar conditions found at Milford. For example, Stony Brook, which has a small drainage area, is responsive to small amounts of precipitation, whereas the other two stations on the Soucook River near Concord and Stony Brook at Merrimack, are less sensitive to small amounts of precipitation (less than 1 in.).

The streamflow-duration data provided in table 4 indicate a relation between the daily discharge of the three reference gaging stations for the days when measurements were collected in Milford with the historical distribution of daily means from the same

Table 4. Streamflow-duration data for daily discharges at three reference streamflow gaging stations for days when measurements were taken in Milford, New Hampshire

[ - no data; figure I shows the location of towns for the following gaging stations: Stony Brook near Temple, N.H. (01093800) drainage area is 3.6 $\mathrm{mi}^{2}$, Souhegan River near Merrimack, N.H. (01094000) drainage area is $171 \mathrm{mi}^{2}$, and Soucook River near Concord, N.H. (01089100) drainage area is $81.9 \mathrm{mi}^{2}$ ]

\begin{tabular}{|c|c|c|c|c|c|c|c|c|c|}
\hline \multirow[b]{2}{*}{ Date } & \multicolumn{3}{|c|}{ Percent of recurrence interval } & \multirow[b]{2}{*}{ Average } & \multirow[b]{2}{*}{ Date } & \multicolumn{3}{|c|}{ Percent of recurrence interval } & \multirow[b]{2}{*}{ Average } \\
\hline & $\begin{array}{l}\text { Stony } \\
\text { Brook }\end{array}$ & $\begin{array}{l}\text { Souhegan } \\
\text { Rlver }\end{array}$ & $\begin{array}{l}\text { Soucook } \\
\text { River }\end{array}$ & & & $\begin{array}{l}\text { Stony } \\
\text { Brook }\end{array}$ & $\begin{array}{l}\text { Souhegan } \\
\text { Aiver }\end{array}$ & $\begin{array}{l}\text { Soucook } \\
\text { Rlver }\end{array}$ & \\
\hline $6 / 14 / 88$ & 80 & $\ldots$ & 86 & 83 & $9 / 12 / 94$ & 87 & 84 & 99 & 90 \\
\hline $9 / 17 / 88$ & 81 & $\ldots$ & 88 & 85 & $9 / 26 / 94$ & 42 & 23 & 84 & 50 \\
\hline $10 / 3 / 88$ & 79 & - & 93 & 86 & $9 / 29 / 94$ & 30 & 22 & 73 & 42 \\
\hline $10 / 13 / 88$ & 71 & - & 82 & 77 & $10 / 11 / 94$ & 59 & 67 & - & 63 \\
\hline $11 / 1 / 88$ & 27 & - & 81 & 54 & $10 / 24 / 94$ & 59 & 61 & -- & 60 \\
\hline $10 / 18 / 90$ & 54 & - & 16 & 35 & $11 / 7 / 94$ & 53 & 74 & -- & 64 \\
\hline $10 / 21 / 90$ & 43 & - & 2 & 23 & $11 / 21 / 94$ & 60 & 77 & -- & 69 \\
\hline $10 / 22 / 90$ & 46 & - & 3 & 25 & $11 / 22 / 94$ & 37 & 65 & - & 51 \\
\hline $4 / 12 / 94$ & 10 & - & 6 & 8 & $12 / 5 / 94$ & 7 & 33 & - & 20 \\
\hline $4 / 13 / 94$ & 4 & -- & 7 & 6 & $12 / 19 / 94$ & - & 31 & - & 31 \\
\hline $4 / 14 / 94$ & 4 & - & 3 & 4 & $1 / 3 / 95$ & - & -- & 25 & 25 \\
\hline $6 / 16 / 94$ & 73 & -- & 72 & 73 & $3 / 13 / 95$ & 25 & 14 & -- & 20 \\
\hline $6 / 21 / 94$ & 81 & -- & 88 & 85 & $3 / 27 / 95$ & 40 & 23 & - & 32 \\
\hline $7 / 5 / 94$ & 92 & -- & 92 & 92 & $4 / 10 / 95$ & 48 & 36 & 40 & 41 \\
\hline $7 / 15 / 94$ & 88 & -- & 96 & 92 & $4 / 24 / 95$ & 47 & 33 & 33 & 38 \\
\hline $7 / 20 / 94$ & 90 & 37 & 97 & 75 & $5 / 8 / 95$ & 69 & 57 & 67 & 64 \\
\hline $8 / 1 / 94$ & 86 & 25 & 88 & 55 & $5 / 22 / 95$ & 50 & 39 & 47 & 45 \\
\hline $8 / 15 / 94$ & 89 & 32 & 97 & 73 & $6 / 5 / 95$ & 39 & 25 & 62 & 42 \\
\hline $8 / 24 / 94$ & 64 & 14 & 88 & 55 & $6 / 28 / 95$ & -- & 85 & 97 & 91 \\
\hline $8 / 29 / 94$ & 81 & 27 & 98 & 69 & $8 / 3 / 95$ & 90 & 89 & - & 90 \\
\hline
\end{tabular}


stations and is listed as the percent of time that the historical daily means have been greater than the daily discharge. Above-average hydrologic conditions were present in Milford on days when the average streamflow durations from referenced stations were low (less than 35). Average hydrologic conditions were present when medium streamflow duration values ( 35 to 65) were present at reference stations, and belowaverage conditions were present when high duration values (greater than 65) occured.

The collection of streamflow data in the study area was done under a wide range of hydrologic conditions, as indicated in table 4. Above average hydrologic conditions are represented by measurements taken April 12-14, 1994, at Milford; the streamflow of daily discharges at two of the three reference stations range from 3 to 10 percent with an average of 6 percent. Average hydrologic conditions are represented by measurements taken during the period of April 10 to June 5, 1995, at Milford; streamflow at the three reference stations ranges from 12 to 68 percent with an average of 44 percent. Below average hydrologic conditions are represented by measurements taken in 1988 excluding November 1, 1988, and measurements taken from June 28 to September 14, 1995; streamflow at the three stations ranges from 71 to 93 percent with an average of 83 percent for 1988 , and streamflow ranges from 85 to 97 percent with an average of 93 percent for 1995 .

In conclusion, precipitation, ground-water levels, and streamflow-duration data can be used to describe the hydrologic conditions in Milford during 1994-95. Annual precipitation in 1994 was 9 percent above the average annual precipitation from 1962-95 and annual precipitation in 1995 was 20 percent below for the same period of record. Ground-water levels from the longterm observation well (MI-18, well number 29) were above average for 1994 and 1995 but the effects of historical withdrawals in the aquifer must be considered. Streamflow durations at the three reference stations averaged 56 percent during 1994-95, which suggests that flows were normal. Therefore, hydrologic conditions in 1994-95 were probably normal and, based on long-term precipitation data, precipitation was slightly above normal in 1994 and slightly below normal in 1995.

\section{Acknowledgments}

The study of the Milford-Souhegan glacial-drift aquifer is a collaborative effort between Federal, State, and local governments, and private companies and individuals. Biweekly ground-water levels and equipement for monitoring surface-water data were provided by New Hampshire Department of Environmental Services and Environmental Sciences and Engineering, Inc. of Amherst, New Hampshire. The authors wish to thank Wayne Ives and Sharon Perkins of the New Hampshire Department of Environmental Services for collecting ground-water level data as part of the biweekly network monitoring described in this report. The authors also appreciate access to private lands that was given by the owners.

\section{METHODS}

Data-collection methods were designed to provide information on the temporal and spatial variability of hydrologic conditions in the MSGD aquifer, in particular, the variability of ground-water levels and the interaction of surface and ground waters. Both hydrologic and physical data were collected. Hydrologic data include measurements of river stage, riverbed water levels, streamflow, and ground-water levels. Physical data include measurements of specific conductance and temperature. Continuous measurements of river stage, riverbed water levels, ground-water levels, specific conductance, and water temperature were made every 15 minutes by electronic sensors and data loggers. Instantaneous measurements of these hydrologic data were also made manually by separate instruments once every 2 weeks (biweekly) or once a month to validate the continuous readings. Manual or noncontinuous measurements were also used to augment spatial coverage of continuousmeasurement sites. Comprehensive synoptic measurements of streamflow and ground-water levels were done during high-flow conditions in April 1994.

River stages, riverbed water levels, and groundwater levels are referenced to sea level. Measurement points were surveyed to nearby USGS geodetic benchmarks by the USGS NH/VT District, and private contractors. 


\section{Surface Water}

Surface water was monitored at over 40 gaging stations throughout the study area. Locations of gaging stations are shown in figure 4. Gaging stations are classified according to frequency of sampling, whether continuous or noncontinuous (manual), and whether the type of measurement is hydrologic (stage, discharge) or physical. Continuous gaging stations provided hydrologic and physical data. Noncontinuous gages were used primarily for hydrologic data collection.

A diagram of a continuous surface-water gaging station is shown in figure 5 . The gaging station consists of an inside, large-diameter, riverbed-stilling well, opened $1 \mathrm{ft}$ below the river bottom, and an outside river pipe that is directly connected to the river. To prevent ice formation during winter months, outside river pipes were installed with a gas bubbler system (not shown).

Measurements of river stage were made with a pressure transducer housed in the river pipe, and measurements of riverbed water levels were made with a potentiometer and attached float and weight in the well open to the riverbed. Concurrent measurements of river stage and riverbed water levels allow for an evaluation of hydraulic connection through the riverbed. Pressure transducers recorded the height of water column in pounds per square inch (psi) above a pressure intake opening in the transducer.

Potentiometers recorded the depth of water level in feet below a known measurement point.

\section{Hydrologic Data}

River stages were monitored continuously at three gaging stations, WLR-1 and WLR-5 on the Souhegan River, and WLR-4 on the discharge ditch. Pressure transducers and potentiometers were used to take measurements every 15 minutes and electronic data loggers stored the readings.

Continuous measurements of river stage from pressure transducers were calibrated against periodic river stage readings from river staff gages and against

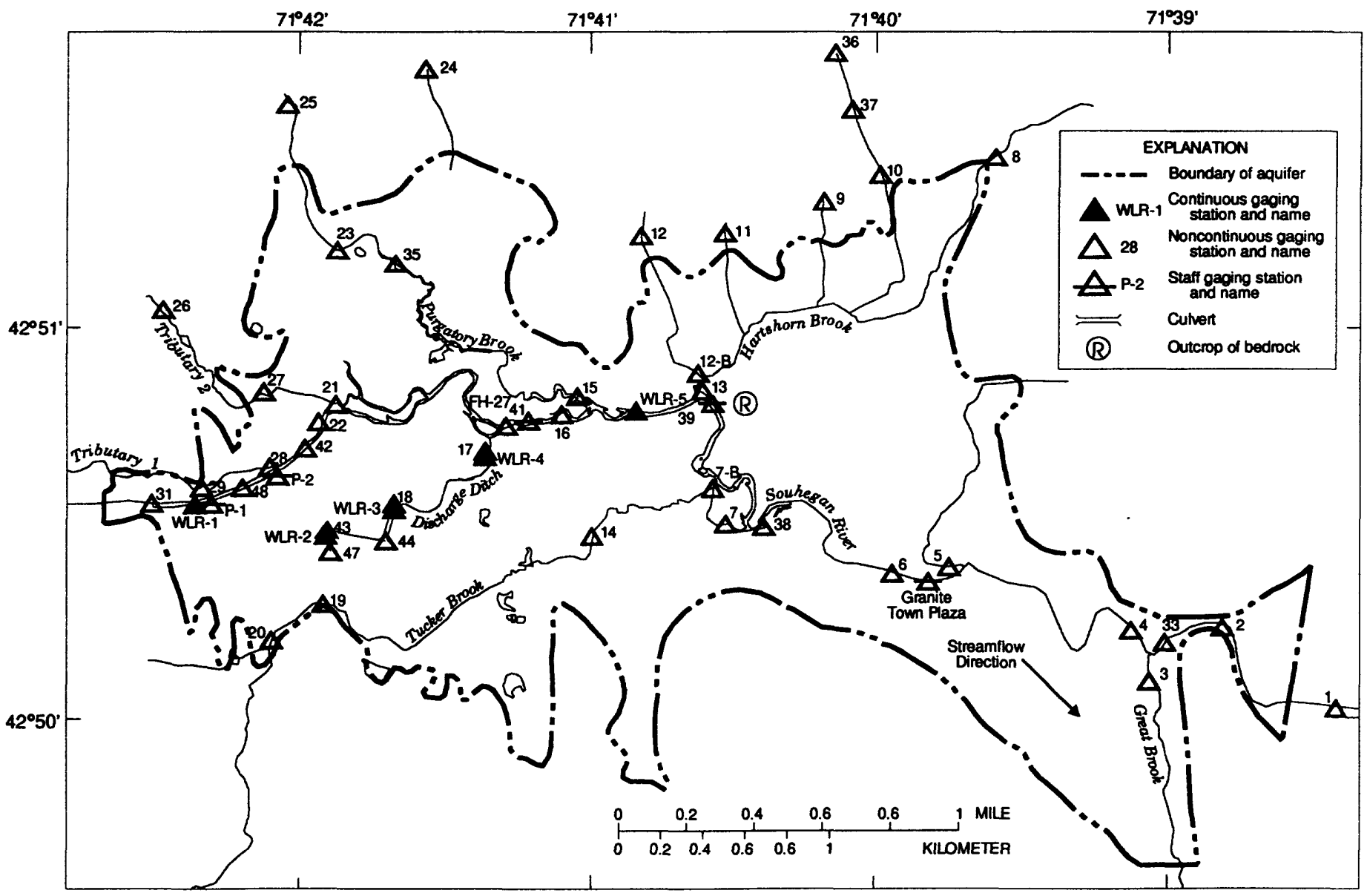

Figure 4. Location of streamflow-gaging stations, Milford, New Hampshire. 


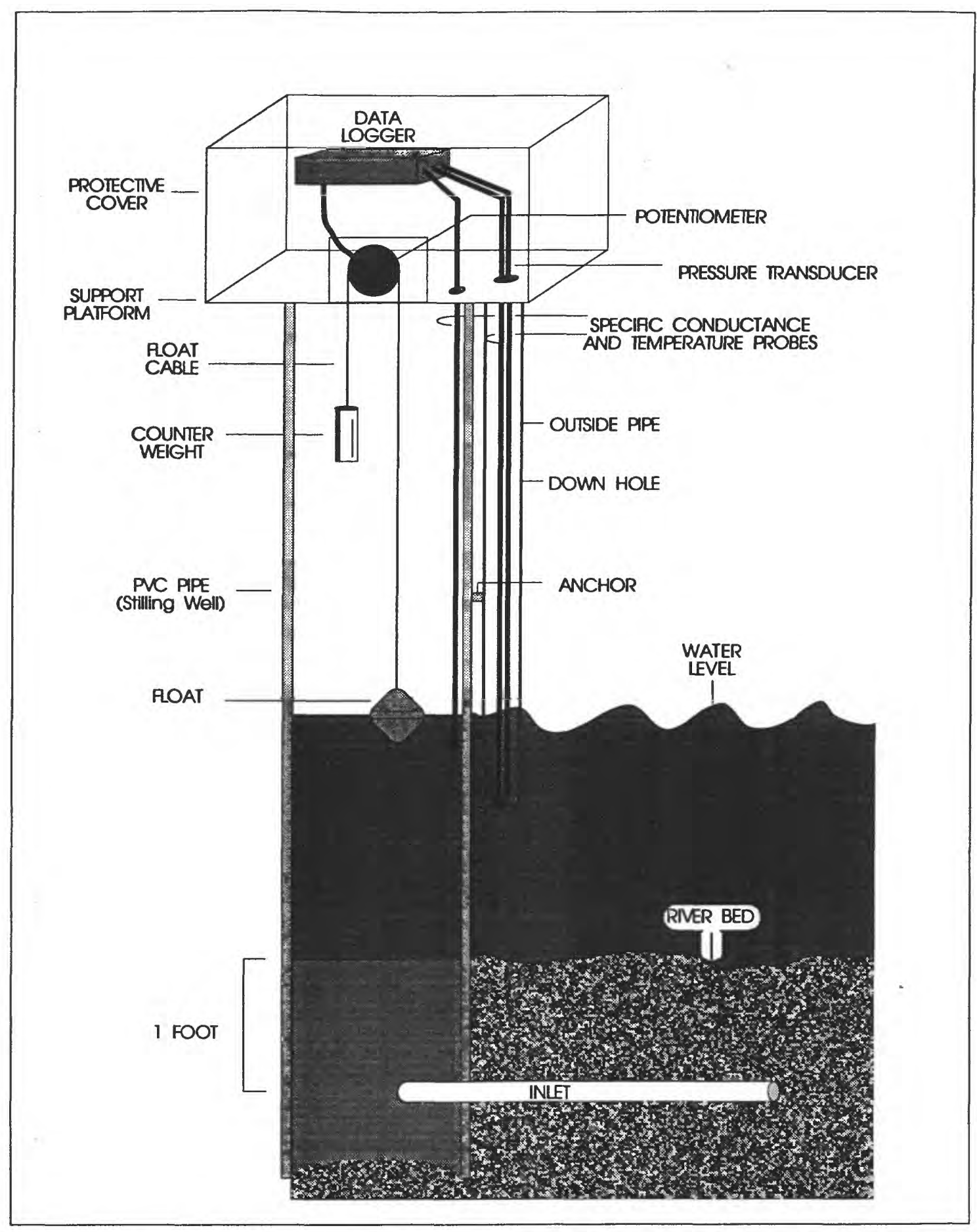

Figure 5. Construction and Instrumentation of a continuous streamflow-gaging station, Milford, New Hampshire.

the depth to water from a known datum point on top of the river pipe. Pressure-transducer readings were not adjusted in the field but corrected using a linear relation between instantaneous readings of psi from the transducer and periodic manual measurements of river stage. The linear equation generated a root mean square (rms) between continuous psi readings and periodic measurements of 0.958 for gage WLR-1, 0.994 for gage WLR-5, and 0.966 for gage WLR-4.

Continuous-riverbed water levels from potentiometers were checked biweekly to monthly for accuracy against periodic measurements made with 
electric water-level probes from known datum points. If a discrepancy exceeded $0.05 \mathrm{ft}$ between the instantaneous reading of the continuous sensor (potentiometer) (fig. 5) and the periodic measurement, continuous readings were adjusted to match the periodic measurement. When corrections were made, continuous readings were later corrected for the time period over which the error occurred. A linear, timeweighted equation was used to adjust continuous readings.

Noncontinuous measurements of river stage were obtained from seven staff gages installed on river banks and used to measure stage to the nearest $0.01 \mathrm{ft}$. Staff gages were leveled to nearby USGS geodetic benchmarks to compute the altitude of the river stage above mean sea level. River staff gages were positioned adjacent to nearby ground-water wells.

Discharge measurements of streamflow were made at 20 sites during high-flow conditions in April 1994 (high-flow synoptic event) and up to 8 sites on a monthly frequency from June 1994 through the summer of 1995. Measurements of discharge were made with current meters by methods adopted by the USGS as described in standard textbooks, (Kantz, 1982a), and the USGS Techniques of Water-Resources Investigations (Coakley and others, 1997, p. 30-31). Methods used are consistent with the American Society for Testing and Materials standards.

At continuous river gages, WLR- 1 and WLR-5 on the Souhegan River, and WLR 4 on the discharge ditch, stage-discharge relations were established to generate a continuous record of streemflow. Discharge relations werc computed using the following methods, as described by Toppin and others (1995). In computing discharge records, results of individual measurements were plotted against the corresponding stages, and stage-discharge relation curves were then constructed. From these curves, rating tables indicating the approximate discharge for any stage within the range of the measurements were prepared. Stage-discharge and riverbed water-level-discharge relation curves were also prepared. To define extremes of discharge outside the range of the current-meter measurements, the curves were extended by transforming the curve to a straight line on a logarithmic-scale plot and extending the straight line to discharges above and below the measured values.
Daily mean discharge was computed by applying each recorded stage in the day to the rating table and computing the mean from the sum of the specific discharges. During the winter, backwater from ice partially obscured the stage-discharge relation at gaging stations; therefore, daily mean discharges were estimated from other information such as temperature and precipitation records, observations of the river channel, and records from other stations in the same or nearby basins for comparable periods.

Daily mean discharges were estimated during periods when no gage heights were obtained, or the recorded gage heights were inaccurate; examples include periods when the recorder stopped or otherwise failed to operate properly, the water level dropped below the measuring level of the sensor, or the float was frozen in the riverbed well. For such periods, the daily discharges were estimated from the previous or subsequent recorded range in stage, discharge measurements, weather records, and comparison with other station records from the same (Souhegan River at Merrimack) or nearby basins. For both WLR-1 and WLR-5, a strong statistical relation is present between the discharges at WLR-1 and WLR-5 and the index stations. The coefficients of determination $\left(\mathrm{r}^{2}\right)$ between the index stations and either WLR-1 or WLR-5 were greater than 0.995 , with a low standard error of less than 0.04 , from the multiple regression analysis. At sites with riverbed water levels, the daily mean discharges were obtained from the relation of water levels to discharge.

Accurate computations of continuous streamflow depend primarily on (1) the accuracy of measurements of stage, measurements of discharge, and interpretation of records (Toppin and others, 1994); and (2) the stability of the stage-discharge relation or, if the control is unstable, the frequency of discharge measurements. Different accuracies may be attributed to different parts of a given record.

An important component of computing continuous streamflows is the accuracy of the discharge measurement; discharge measurements are rated during the measurement as excellent, good, fair, and poor. An excellent rating means that about 95 percent of the daily discharges are within 5 percent of their true values; "good," within 10 percent; "fair," within 15 percent; and greater than 15 percent are rated "poor". Dishcarge measurements on the Souhegan River for stations 
WLR-1 and WLR-5 were rated excellent to good. Discharge measurements on the drainage ditch were rated good to fair.

A good stage-discharge relation is available for stations WLR-1 and WLR-5 on the Souhegan, but a poor relation is available for station WLR-4 on the discharge ditch. Continuous streamflows computed for the Souhegan River are believed to be accurate to within 5 percent of their true value. Computation of continuous streamflow computed for the discharge ditch was not possible because of the poor relation between recorded stage and measured discharge because of heavy vegetation growth in the ditch.

Daily mean discharges in this report are given to the nearest hundredth of a cubic foot per second for values less than $1 \mathrm{ft}^{3} / \mathrm{s}$; to the nearest tenth for values between 1.0 and $10 \mathrm{ft}^{3} / \mathrm{s}$; to whole numbers for values between 10 and $1,000 \mathrm{ft}^{3} / \mathrm{s}$; and to 3 significant figures for values more than $1,000 \mathrm{ft}^{3} / \mathrm{s}$. The number of significant figures used is based solely on the magnitude of the discharge value.

\section{Physical Data}

Specific conductance and temperature of river waters and riverbed waters were collected continuously, every 15 minutes, at the same stations (WLR-1, WLR-5, and WLR-4) where continuous river stages and riverbed water levels were collected. These parameters were measured by use of water-quality sensors designed by the USGS and recorded concurrently on the same data loggers used to measure river stage and riverbed water levels. Air temperatures were also measured by use of thermistors connected to the data loggers for comparison and possible correlation with water temperatures.

Continuous specific-conductance and temperature measurements were checked biweekly or monthly by comparison with readings from manually operated water-quality instruments. Water-quality sensors were also periodically checked against known standards to ensure correct readings.

Standards of specific conductance were selected to bracket representative ranges of observed field concentrations and included buffer concentrations of 50,250 , and $500 \mu \mathrm{S} / \mathrm{cm}$ at $25^{\circ} \mathrm{C}$. For river waters, the manually operated sensors were placed on the outside of the river pipe and readings were compared to continuous readings. For riverbed waters, the manually operated sensors were lowered down the stilling well to obtain readings.

Unlike measurements of river stage and riverbed water levels, continuous values of specific conductance were not adjusted to manual readings if differences were present. This is because specific conductance measurements are subjected to greater error than measurements of hydraulic head. However, a long-term comparison of continuous specific conductance values with manual values was done to evaluate the relative reliability of continuous specific-conductance sensors. If three or more manual readings differed from the continuous reading by more than 10 percent, the probe for the continuous specific-conductance sensor was cleaned with soap; this typically corrected the problem. For this report, reported values of specific conductance are accurate to at least $50 \mu \mathrm{S} / \mathrm{cm}$.

Continuous measurements of water temperature were also not adjusted to discrete readings if discrepancies were present. Water temperature values are more accurate than specific conductance.

Differences between continuous and manual values were estimated to be less than approximately 5 percent of continuous readings. For this report, water temperatures have an accuracy of at least $5^{\circ} \mathrm{C}$.

Continuous measurements of air temperature were checked against thermometers. Like comparison of water temperatures, differences between continuous values and periodic measurements were small.

\section{Ground Water}

Information on ground-water flow was collected from wells distributed throughout the aquifer (figs. 6 and 7 and plate 1), including the location of observation wells, pumping wells and unused withdrawal wells. Observation wells are classified according to frequency of measurement, and include continuous and noncontinuous wells. At three of the five continuously measured wells [P-1 (well number 335), P-2 (336), and MW-2A (310)], hydrologic (water levels) and physical data were collected. At the other two continuously measured wells [MW-5B (213) and MI-18 (29)], only hydrologic data were collected (fig. 6). Noncontinuous recording observation wells are further classified between wells measured biweekly or as part of the highflow synoptic. Biweekly measured wells are shown in 


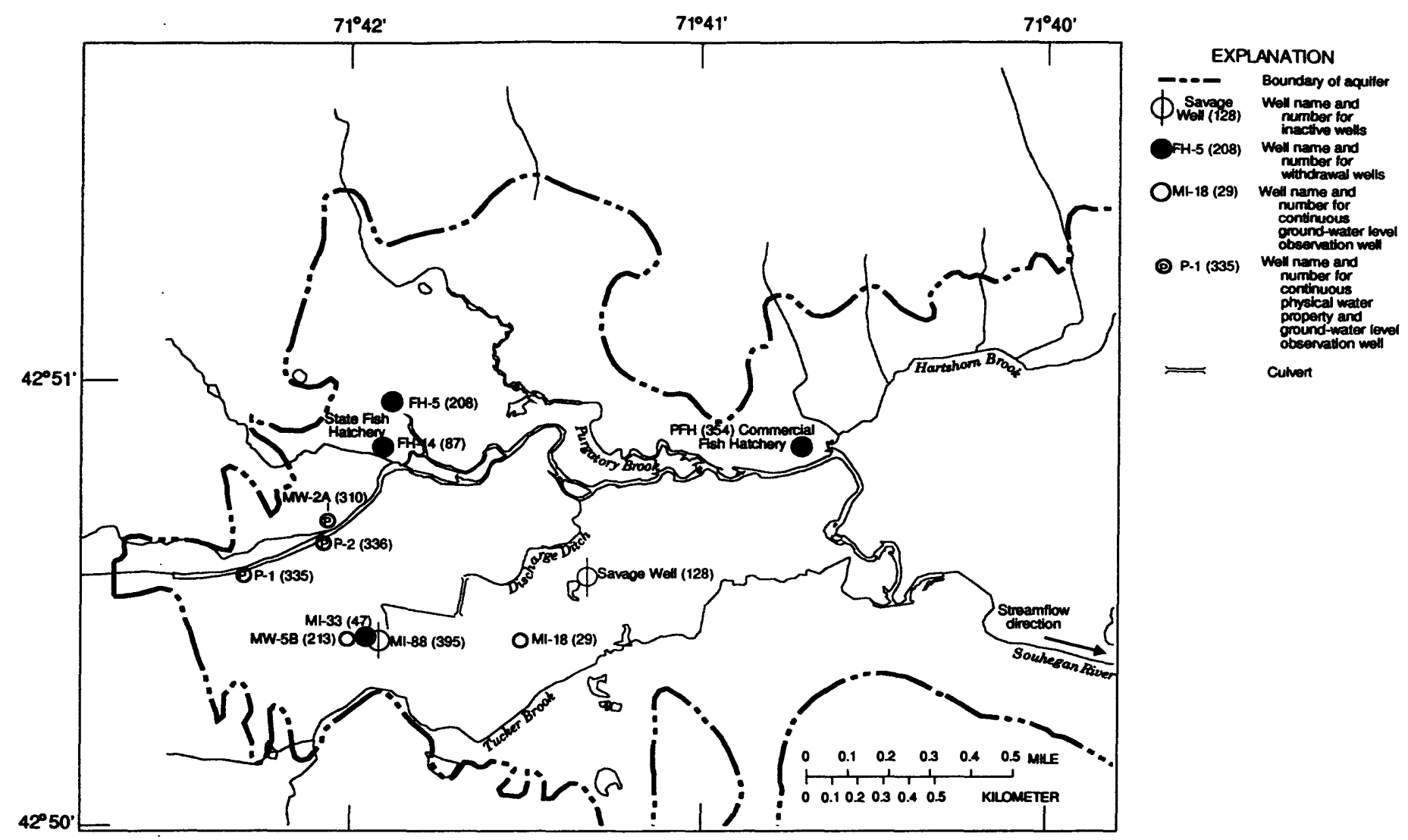

Figure 6. Location of continuous physical water-property and ground-water observation wells, Milford, New Hampshire.

figure 7. Wells measured during the synoptic are in plate 1. Well construction data are given in Appendix 1.

The design of multi-property (water levels, specific conductance, and temperature), continuously monitored ground-water wells is shown in figure 8 . The use of multiple probes withm small, 2-in diameter wells was made possible by inserting several smaller diameter pipes inside the two-inch well and hanging the probes inside the smaller diameter pipes. These smaller pipes prevented entanglement and interference of the multiple probes inside the well. Access tubes were inserted to allow for manual measurements of water levels and withdrawals of water (see section on physical data). Probes that measured physical water properties were placed near the screen to ensure that readings represented aquifer water and not stagnant borehole water.

\section{Hydrologic Data}

Continuous measurements of ground-water levels were made with potentiometers and attached floats and counterweights at wells P-1, P-2 and MI-18, and pressure transducers at wells MW-2A, and MW-5B. Procedures for calibration were the same as for river stage and riverbed water levels.

Measurements made with potentiometers in 2-in diameter wells (P-1 and P-2) were difficult to obtain because of friction between the attached float and weight and the inside of the inner, small-diameter pipe housing the float and weight (fig. 8). Differences between continuous and manual measurements were up to $0.3 \mathrm{ft}$. Corrections were made in the field if differences exceeded $0.05 \mathrm{ft}$, as were found with continuous riverbed water levels. In cases where corrections were made, a linear time-weighted equation was applied to adjust the continuous readings to match the manual measurements over the period between the previous visit and the current visit.

Continuous ground-water-level measurements at well MW-5B were made with a pressure transducer and data logger. These data were collected by a private consulting company (Allise deSmet, Environmental Science and Engineering, Inc., written commun., 1995). 


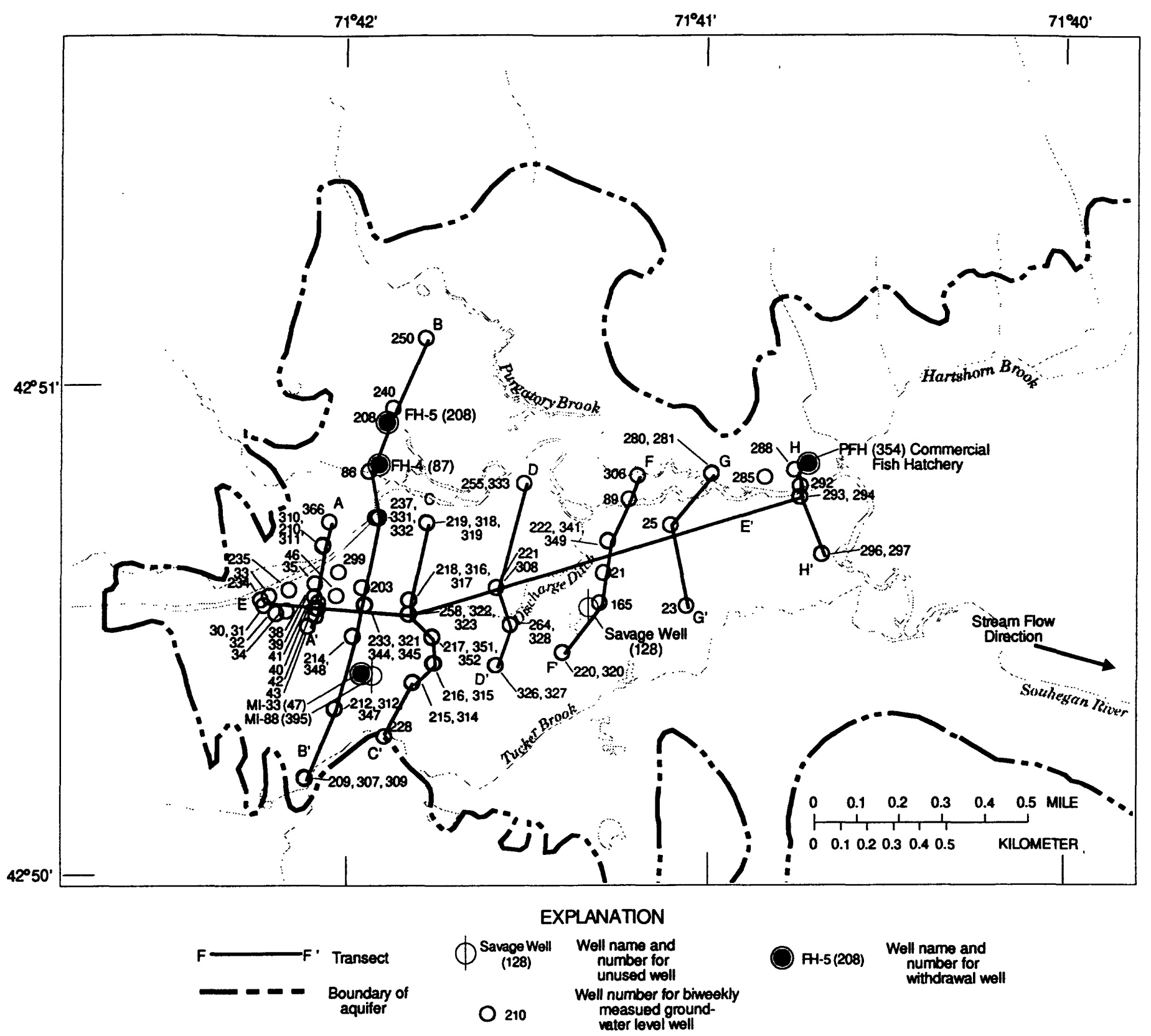

Figure 7. Location of biweekly measured ground-water level wells, Milford, New Hampshire.

Manual measurements of ground-water levels were collected biweekly for 1 year at 87 wells by personel at NHDES and ESE, Inc. Well locations were chosen along transects of the aquifer (fig. 7). These data were used to compute transient hydraulic gradients across transects of the MSGD. Biweekly hydraulic gradients were computed from wells located at the end of the transect unless the direction of the gradient changed along the transect at any given time. If the gradient changed direction along the transect, the transect was divided into segments that had uniform directional gradients, and water levels from wells at the boundaries of the segments were used to compute gradients. Transects were located throughout the contaminant plume and other critical areas of the ground-water-flow field and are labeled alphabetically from west to east for quick reference.

Hydraulic gradients along transects primarily represent apparent gradients and not maximum gradients because the transect may not be aligned with the maximum potential slope of the water table. To 




Figure 8. Construction and instrumentation fo continuous ground-water observation wells, Milford, New Hampshire.

approximate maximum gradients more closely, gradients were computed by a three-point planar solution (Marschak and Mitra, 1988) through triangular grouping of wells. Although this technique is an improvement in measuring gradients in the aquifer, and determining the direction of maximum gradient, the direction of maximum hydraulic gradient may not coincide with the primary direction of ground-water flow if the aquifer is anisotropic. Horizontal anisotropy has not been clearly demonstrated in the western part of the aquifer; therefore, it is reasonable to assume that primary flow direction is aligned with the direction of maximum slope. 
Manual measurements of ground-water levels also were made at 115 wells during high-flow conditions (high-flow synoptic) in April 1994 (pl. 1).

Measurements made during the high-flow synoptic were compared to previous synoptic events in October 1988 and 1990.

\section{Physical Data}

Data for physical properties — specific conductance and temperature of ground waters- were collected continuously, every 15 minutes, at three wells (P-1, P-2, and MW-2A). Physical properties were measured by the same type of sensors used at surfacewater sites.

The procedure for checking continuous physical properties at wells was difficult because of the small diameter of these wells ( 2 inches). Water samples were withdrawn by use of a peristaltic pump so that manual measurements of specific conductance and water temperature could be made. Wells were pumped during the interval between automated 15-minute recordings of water levels so as not to affect the operations of the sensors. Methods of checking continuous values of specific conductance and temperature followed the same protocols used at surface-water sites.

\section{Surface-Water and Ground-Water Interactions}

The surface- and ground-water data network was also designed to collect information on the interactions between surface and ground water. These interactions include (1) continuous and manual measurements of river stage, riverbed water levels, and adjacent groundwater levels to compute hydraulic gradients between surface and ground waters; (2) continuous measurements of specific conductance and temperature to identify chemical signatures and transport directions between surface and ground waters; and (3) streamflow measurements along stream reaches to identify river seepage and ground-water recharge and discharge patterns.

Streamflow data were used to estimate mean ground-water discharge and relative contributions of ground water to streamflow, called base flow. The percentage of base flow at WLR- 5 was computed by methods described by Rutledge (1993, p. 33-39).

\section{RESULTS OF HYDROLOGIC DATA COLLECTION}

Hydrologic data presented in the report include graphs of daily averages of continuously measured river stages and riverbed water levels, streamflow discharges, and continuously and biweekly measured ground-water levels. Tables of manual measurements of river stages, streamflow, and ground-water levels are also provided. Instantaneous readings from continuous data are not reported but are available from the USGS upon request.

\section{Surface Water}

River stages ranged from $5 \mathrm{ft}$ at WLR- 1 to $7 \mathrm{ft}$ at WLR-5 on the Souhegan River but fluctuated less than $2 \mathrm{ft}$ at WLR-4 on the discharge ditch (fig. 9). Riverchannel geometry probably plays a role in the variability of river-stage fluctuations between WLR-1 and WLR-5. At WLR-1, the broad river channel probably minimizes stage fluctuations. At WLR-5, the river channel is confined within deeply incised banks, which probably accounts for the fact that stage fluctuations are greater at WLR-5 than at WLR-1. At WLR-4 on the discharge ditch, streamflow is fed primarily by processed waters from an industrial facility. The constant flow of these waters minimizes river-stage fluctuations. At all three continuous gaging stations (WLR-1, -4, -5), riverbed water levels mimic river stages. In December 1994, maximum river stages and riverbed water levels might have been the result of snowmelt caused by above-average precipitation and unseasonably warm temperatures. River-stage data from manual measurements are given in appendix 2 .

Daily mean discharge ranged from approximately $15 \mathrm{ft}^{3} / \mathrm{s}$ in July 1994 to more than $1,500 \mathrm{ft}^{3} / \mathrm{s}$ in December 1994 on the Souhegan River at gaging stations WLR-1 and WLR-5 (fig. 10). Streamflow at the upstream gage WLR-1 and the downstream gage WLR5 are similar, with WLR 5 having slightly greater discharge rates than WLR-1. A continuous streamflow discharge record could not be generated for gaging station WLR-4 because of a poor relation between stage and discharge. This relation is attributed to the effect of vegetative growth and the creation of variable backwater conditions in the discharge ditch.

Manual discharge measurements of streamflow indicate that the Souhegan River gains from about $I$ and 


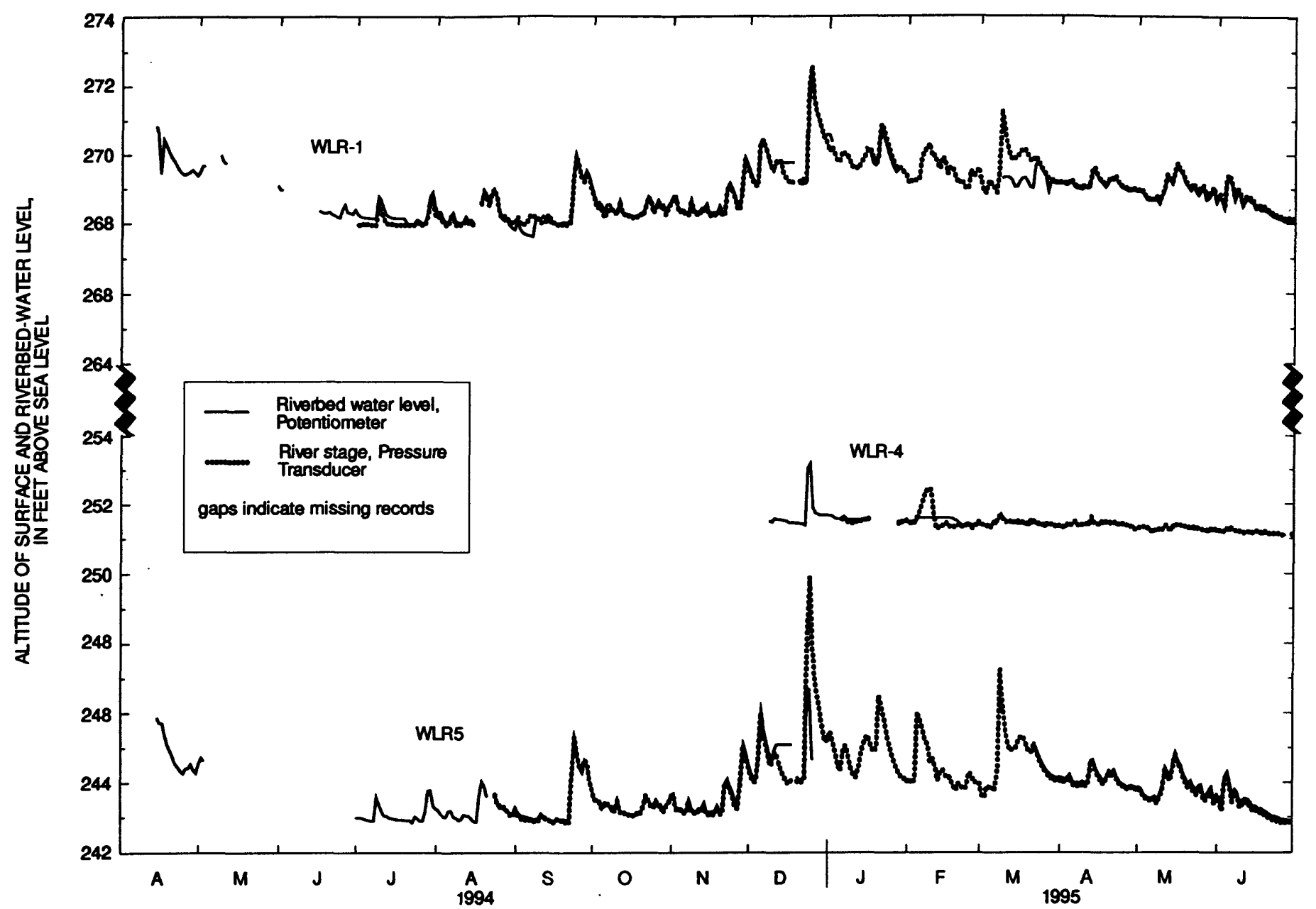

Figure 9. River stage and riverbed water levels at streamflow-gaging stations WLR-1, WLR-5, and WLR-4, Milford, New Hampshire.

$1 / 2$ to $30 \mathrm{ft}^{3} / \mathrm{s}$ between gaging stations WLR-1 and WLR-5 (table 5) during streamflow discharges of several tens to several hundred cubic feet per second. On October 11, 1994, the Souhegan River lost $11.2 \mathrm{ft}^{3} / \mathrm{s}$ during a moderate streamflow regime; index stations had an average streamflow duration of 74 percent on October 11, 1994 (table 4). Streamflow in the discharge ditch was generally less than $1 \mathrm{ft}^{3} / \mathrm{s}$.

Transient variations in streamflow gains/losses along four river reaches were investigated by computing the change in discharge between an upstream and corresponding downstream measurement station (two reaches each on the Souhegan River and discharge ditch (figs. 11 and 12). Net streamflow gains and losses of a river reach were computed by subtracting discharge measured at a downstream station from a discharge measured at its corresponding upstream station. The length of each river reach is approximately $1,000 \mathrm{ft}$, as defined by the location of the coupled measurement stations. Successive discharge measurements of coupled upstream and downstream stations took about 3 hours and were done on days reported in table 5 . Investigative reaches and coupled measurement stations on the Souhegan River include WLR-1 and P-2, WLR-5 and station 39 (by an outcropping of bedrock) (fig. 4). Coupled measurement stations on the discharge ditch are between WLR-2 and WLR-3, and between WLR-3 and WLR-4. A streamflow loss is indicated on the graph (figs. 11 and 12) by a positive change in discharge and streamflow gain by a negative change in discharge. The magnitude of discharge at station WLR-5 is shown in figure $11 \mathrm{c}$ for comparison to coupled measurements on the Souhegan River. The magnitude of discharge at station WLR-3 is shown in figure $12 \mathrm{c}$ for comparison to coupled measurements on the discharge ditch. An evaluation of the relative amount of streamflow gain/loss per total 
Table 5. Streamflow discharge from monthly measurements for selected streamflow-gaging stations, Milford, New Hampshire

[Locations for selected gaging-station sites are shown in figure 4. (WLR-1), continuous gaging station; (P-2), staff gaging station; (6), noncontinuous gaging station. Stage in feet above sea level; discharge in cubic feet per second; -, no data]

\begin{tabular}{|c|c|c|c|c|c|c|c|c|c|c|c|c|}
\hline \multirow[b]{2}{*}{ Date } & \multicolumn{3}{|c|}{ (WLR-1) Souhegan River } & \multicolumn{3}{|c|}{ (P-2) Souhegan River } & \multicolumn{3}{|c|}{ (WR-5) Souhegan River } & \multicolumn{3}{|c|}{ (39) Souhegan River } \\
\hline & Time & Stage & $\begin{array}{c}\text { Dis- } \\
\text { charge }\end{array}$ & Time & Stage & $\begin{array}{c}\text { Dis- } \\
\text { charge }\end{array}$ & Time & Stage & $\begin{array}{c}\text { Dis- } \\
\text { charge }\end{array}$ & Time & Stage & $\begin{array}{c}\text { Dis- } \\
\text { charge }\end{array}$ \\
\hline June 16,1994 & 1215 & 268.37 & 42.2 & 1300 & - & 40.8 & 1350 & - & 46.7 & - & - & - \\
\hline July 20, 1994 & 0750 & 267.97 & 15.4 & 0900 & 261.38 & 15.9 & 1020 & 242.94 & 18.5 & - & - & - \\
\hline August 24, 1994 & 0740 & 269.06 & 139 & 0900 & 262.43 & 143 & 1000 & 244.08 & 150 & - & - & - \\
\hline Sept 29, 1994 & $\begin{array}{l}0840 \\
0940\end{array}$ & $\begin{array}{l}269.52 \\
269.46\end{array}$ & $\begin{array}{l}236 \\
236\end{array}$ & $\begin{array}{c}1040 \\
-\end{array}$ & $\begin{array}{c}262.84 \\
-\end{array}$ & $\begin{array}{r}224 \\
-\end{array}$ & $\begin{array}{c}1210 \\
-\end{array}$ & $\begin{array}{c}244.62 \\
-\end{array}$ & $\begin{array}{r}234 \\
-\end{array}$ & - & - & - \\
\hline Oct 11,1994 & 1110 & 268.84 & 88.3 & 1200 & 262.00 & 65.0 & 1250 & 243.71 & 77.1 & 1335 & 234.51 & 71.2 \\
\hline Nov 22,1994 & 1030 & 269.02 & 131 & 1110 & 262.33 & 117 & 1200 & 244.08 & 135 & 1245 & 235.00 & 151 \\
\hline Dec 12, 1994 & 0910 & 269.39 & 164 & 1005 & 262.52 & 156 & 1050 & 244.26 & 189 & 1145 & 235.21 & 196 \\
\hline Jan 181995 & 0945 & 270.08 & 393 & - & - & - & - & - & - & - & - & - \\
\hline $\operatorname{Jan} 26,1995$ & 0725 & 269.79 & 297 & 0825 & 263.11 & 285 & 0935 & 244.93 & 336 & - & - & - \\
\hline Feb 27, 1995 & 1000 & 269.45 & 133 & 1100 & 265.93 & 134 & 1320 & 244.30 & 161 & 1400 & 235.52 & 169 \\
\hline March 27, 1995 & 0915 & 269.38 & 196 & 1000 & 262.70 & 189 & 1100 & 244.46 & 226 & 1150 & 235.41 & 234 \\
\hline April 24, 1995 & 0815 & 269.09 & 141 & 0850 & 262.47 & 147 & 0930 & 244.15 & 167 & 1115 & 235.14 & 178 \\
\hline May 221995 & 0800 & 269.01 & 129 & 0845 & 262.33 & 121 & 0930 & 244.00 & 139 & 1115 & 235.03 & 160 \\
\hline June 28,1995 & 0800 & 268.07 & 17.8 & 0850 & 261.53 & 19.5 & 1030 & 243.02 & 21.5 & 1115 & 233.87 & 23.0 \\
\hline Aug 03, 1995 & 0900 & 268.15 & 23.4 & 945 & 261.63 & 22.5 & 1030 & 243.07 & 25.5 & 1115 & 233.92 & 26.1 \\
\hline Sept 14, 1995 & 0915 & - & 5.10 & 1000 & - & 4.58 & 1055 & - & 6.71 & 1140 & - & 6.85 \\
\hline \multirow[b]{2}{*}{ Date } & \multicolumn{3}{|c|}{ (6) Souhegan River } & \multicolumn{3}{|c|}{ (WLR-2) Discharge Ditch } & \multicolumn{3}{|c|}{ (WLR-3) Discharge Ditch } & \multicolumn{3}{|c|}{ (WR-4) Discharge Ditch } \\
\hline & Time & Stage & $\begin{array}{c}\text { Dis- } \\
\text { charge }\end{array}$ & Time & Stage & $\begin{array}{c}\text { Dis- } \\
\text { charge }\end{array}$ & Time & Stage & $\begin{array}{c}\text { Dis- } \\
\text { charge }\end{array}$ & Time & Stage & $\begin{array}{c}\text { Dis- } \\
\text { charge }\end{array}$ \\
\hline June 16, 1994 & - & - & - & 1100 & 262.43 & 0.354 & 1005 & 255.94 & 0.505 & 0920 & 251.08 & 0.283 \\
\hline July 20, 1994 & - & - & - & 1210 & 262.45 & .540 & 1315 & 255.92 & .450 & 1415 & 251.54 & .140 \\
\hline Aug 24, 1994 & - & - & - & 1200 & 262.46 & .674 & 1240 & 255.88 & .540 & 1315 & 251.31 & .484 \\
\hline Sept 29, 1994 & - & - & - & 1315 & 262.46 & .540 & 1355 & 255.94 & .500 & 1420 & 251.44 & .390 \\
\hline Oct 11,1994 & - & - & - & 0750 & 262.45 & .418 & 0910 & 256.10 & .441 & 1025 & 251.36 & .218 \\
\hline Nov 22, 1994 & - & - & - & 0750 & 262.44 & .397 & 0945 & 256.10 & .413 & 0855 & 251.36 & .249 \\
\hline Dec 19, 1994 & - & - & - & 0745 & 262.42 & .363 & 850 & 256.05 & .493 & 0820 & 251.54 & .302 \\
\hline Jan 18, 1995 & - & - & - & 0740 & 262.44 & .438 & 0850 & 256.09 & .486 & 0820 & 251.62 & .661 \\
\hline Jan 26,1995 & - & - & - & - & - & - & - & - & - & - & - & - \\
\hline June 16, 1994 & - & - & - & 1100 & 262.43 & .354 & 1005 & 255.94 & .505 & 0920 & 251.08 & .283 \\
\hline July 20, 1994 & - & - & - & 1210 & 262.45 & .540 & 1315 & 255.92 & .450 & 1415 & 251.54 & .140 \\
\hline Aug 24, 1994 & - & - & - & 1200 & 262.46 & .674 & 1240 & 255.88 & .540 & 1315 & 251.31 & .484 \\
\hline Sept 29, 1994 & - & - & - & 1315 & 262.46 & .540 & 1355 & 255.94 & .500 & 1420 & 251.44 & .390 \\
\hline Oct 11,1994 & - & - & - & 0750 & 262.45 & .418 & 0910 & 256.10 & .441 & 1025 & 251.36 & .218 \\
\hline Nov 22, 1994 & - & - & - & 0750 & 262.44 & .397 & 0945 & 256.10 & .413 & 0855 & 251.36 & .249 \\
\hline Dec 19, 1994 & - & - & - & 0745 & 262.42 & .363 & 850 & 256.05 & .493 & 0820 & 251.54 & .302 \\
\hline Feb 27, 1995 & - & - & - & 0720 & 262.54 & .338 & 0855 & 256.04 & .407 & 0820 & 251.39 & .176 \\
\hline March 27, 1995 & - & - & - & 0745 & 262.54 & .305 & 0845 & 256.02 & .443 & 0825 & 251.44 & .428 \\
\hline April 24, 1995 & - & - & - & 0745 & 262.56 & .339 & 0835 & 256.01 & .438 & 0710 & 251.48 & .309 \\
\hline May 22, 1995 & - & - & - & 0650 & 262.55 & .323 & 0740 & 256.00 & .357 & 0720 & 251.34 & .398 \\
\hline June 28,1995 & 0935 & - & 21.9 & 0625 & 262.59 & .376 & 0730 & 256.04 & .402 & 0710 & 251.07 & .211 \\
\hline Aug 3, 1995 & 0815 & - & 27.8 & 0655 & 262.57 & .405 & 0845 & 256.28 & .385 & 0725 & 251.16 & .157 \\
\hline Sept 14,1995 & 0740 & - & 7.52 & 0705 & -- & .431 & 0840 & - & .358 & - & - & - \\
\hline
\end{tabular}




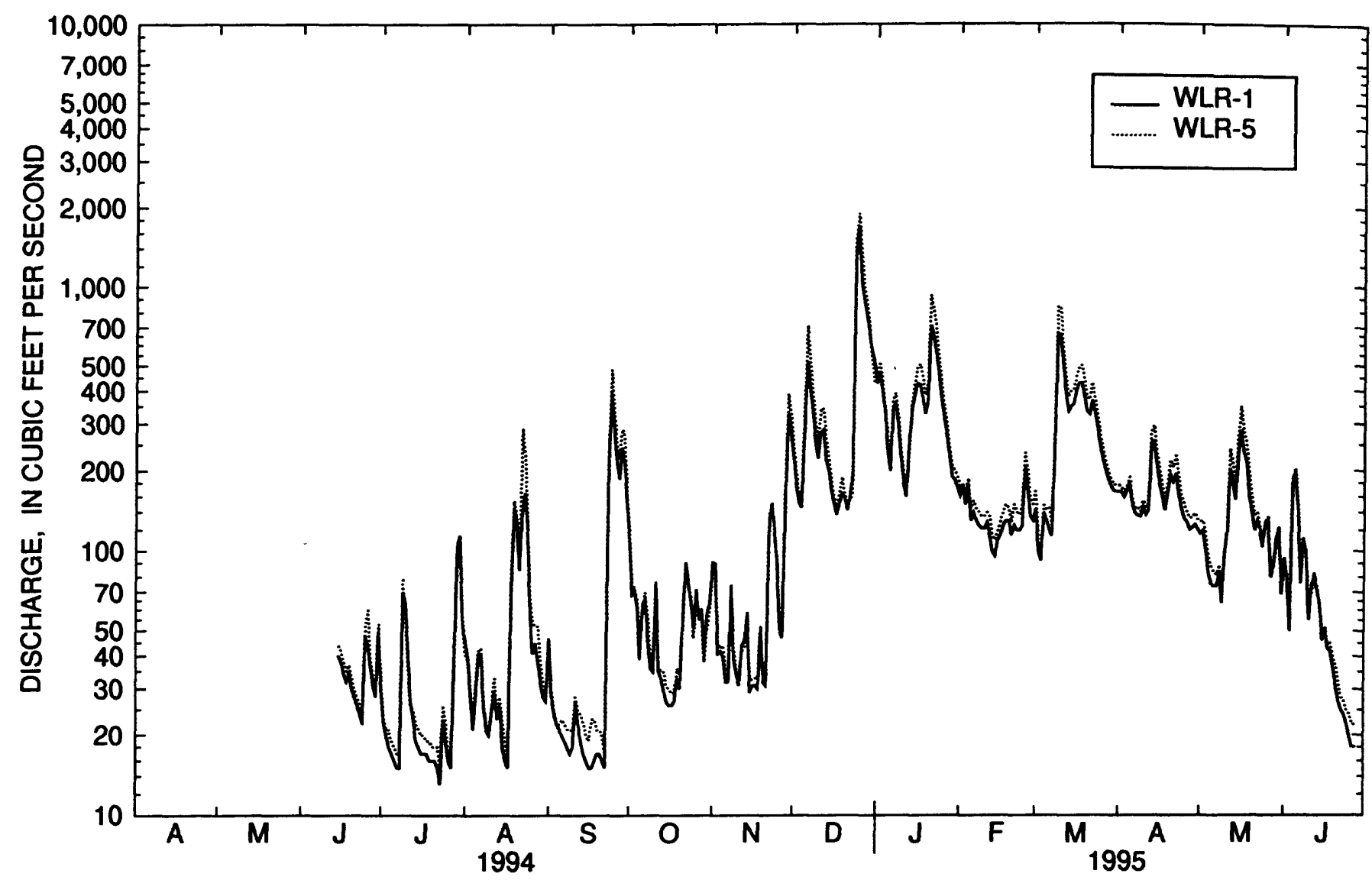

Figure 10. Daily mean dlscharge fort streamflow-gaging stations WLR and WLR-5, Milford, New Hampshire.

streamflow can be done if the change in discharge is compared to magnitude of discharge.

All reaches show fluctuations or transient shifting between streamflow gain and loss (figs. 11 and 12) but results also show that each reach is predominantly a gaining reach or a losing reach. Predominantly losing reaches include the upstream reach ${ }^{1}$ between WLR-1 and P-2 on the Souhegan River and along the downstream reach between WLR-3 and WLR-4 on the discharge ditch; a majority of measurements show a net decrease in discharge from the upstream to the downstream station. Conversely, predominantly gaining reaches include the downstream reach between WLR-5 and station 39 on the Souhegan River and along the upstream reach between WLR-2 and WLR-3 on the discharge ditch; a majority of measurements show a net increase in discharge from the upstream to the

\footnotetext{
'The upstream reach of the Souhegan River in Milford is a transition zone between a narrow confined valley in the town of Wilton to a wide open valley in Milford. The transition is marked by an increase in the transmissivity of valley sediments from the narrow to wide valley, which facilitates streamflow loss.
}

downstream station. The magnitude of total discharge seems to have had no effect on whether a reach shifts between a losing or gaining reach.

In general, net discharge along the upstream reach of the Souhegan River, between WLR-1 and P-2, averages a streamflow loss of $4.9 \mathrm{ft}^{3} / \mathrm{s}$, whereas net discharge along the downstream reach of the Souhegan River, between WLR-5 and station 39, averages a streamflow gain of $6.8 \mathrm{ft}^{3} / \mathrm{s}$ (fig. 11). Streamflow losses were at a maximum during the fall of 1994 and winter of 1994-95 along the upper reach between WLR-1 and P-2 (fig. 11). On the discharge ditch, net discharge along the upstream reach, between WLR-2 and WLR-3, averages a $0.03 \mathrm{ft}^{3} / \mathrm{s}$ streamflow gain, whereas net discharge along the downstream reach between WLR-3 and WLR-4 averages a streamflow loss of $0.15 \mathrm{ft}^{3} / \mathrm{s}$.

Although the tendency of a reach to lose or gain is apparently unaffected by the magnitude of streamflow, the magnitude that a reach loses or gains is nevertheless partly affected by the limits of total streamflow through a reach. This is important because the potential amount of available gain or loss will increase with increasing 
a)

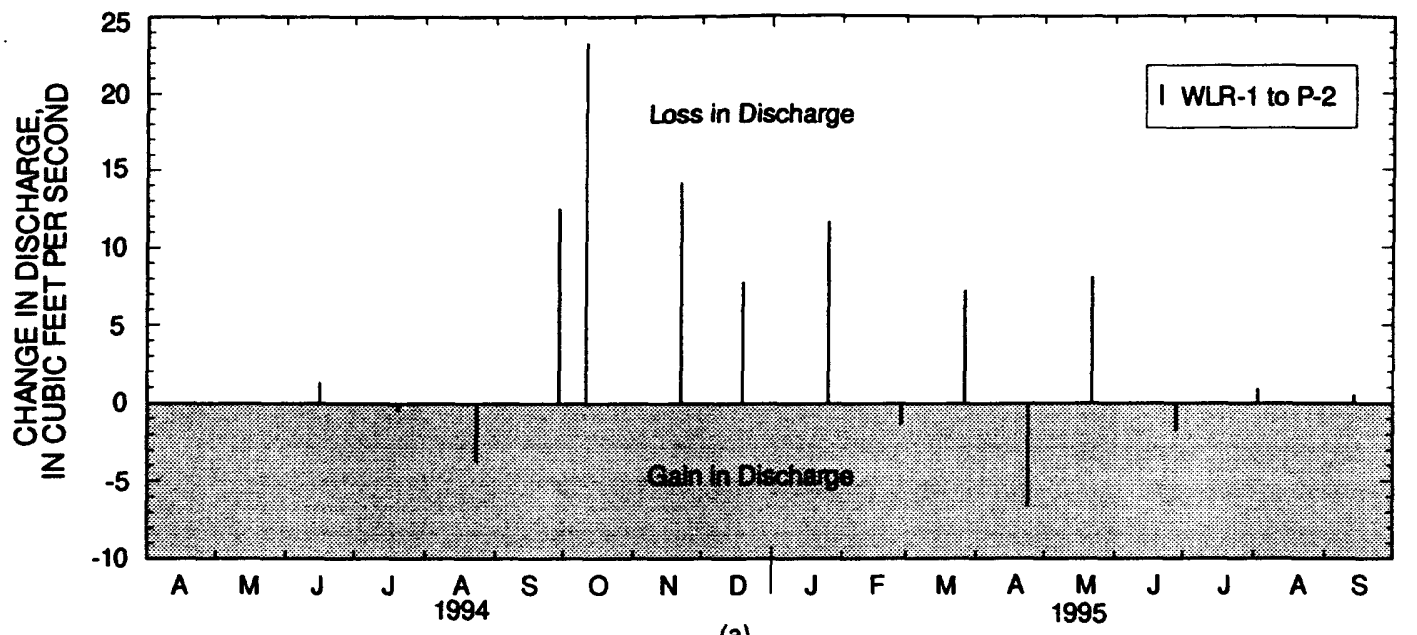

b)

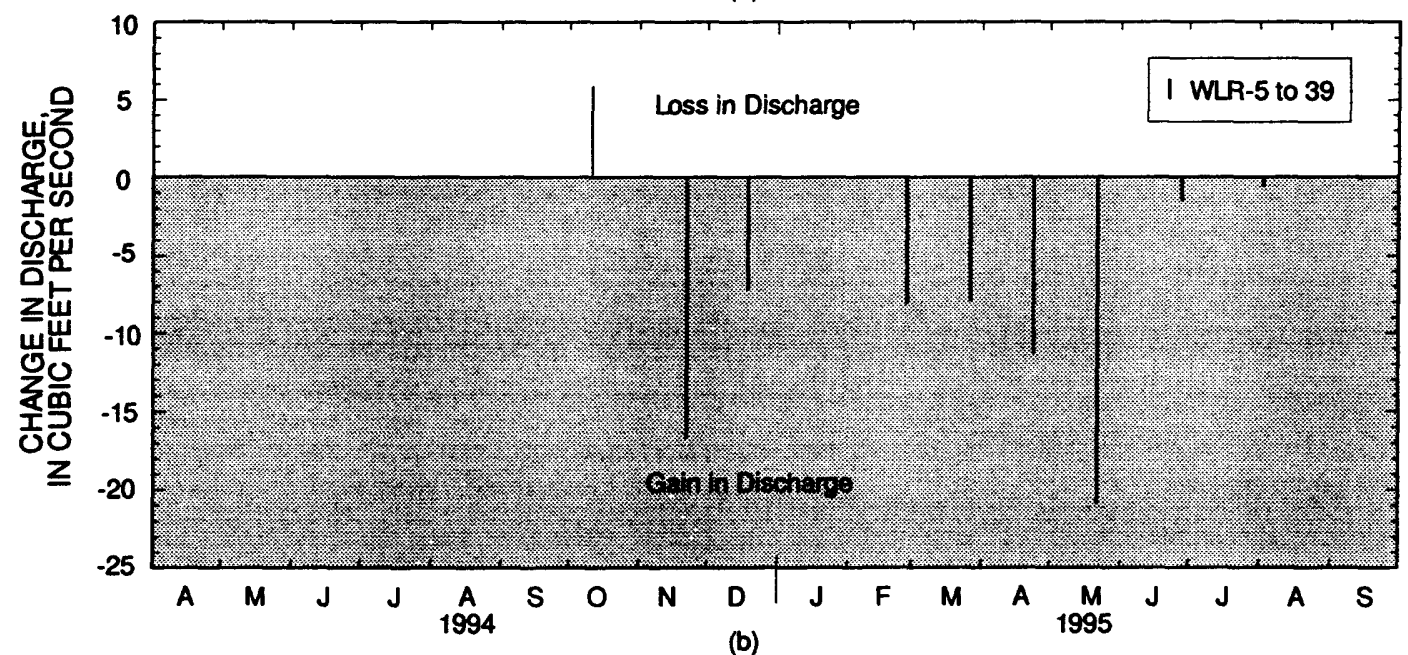

c)

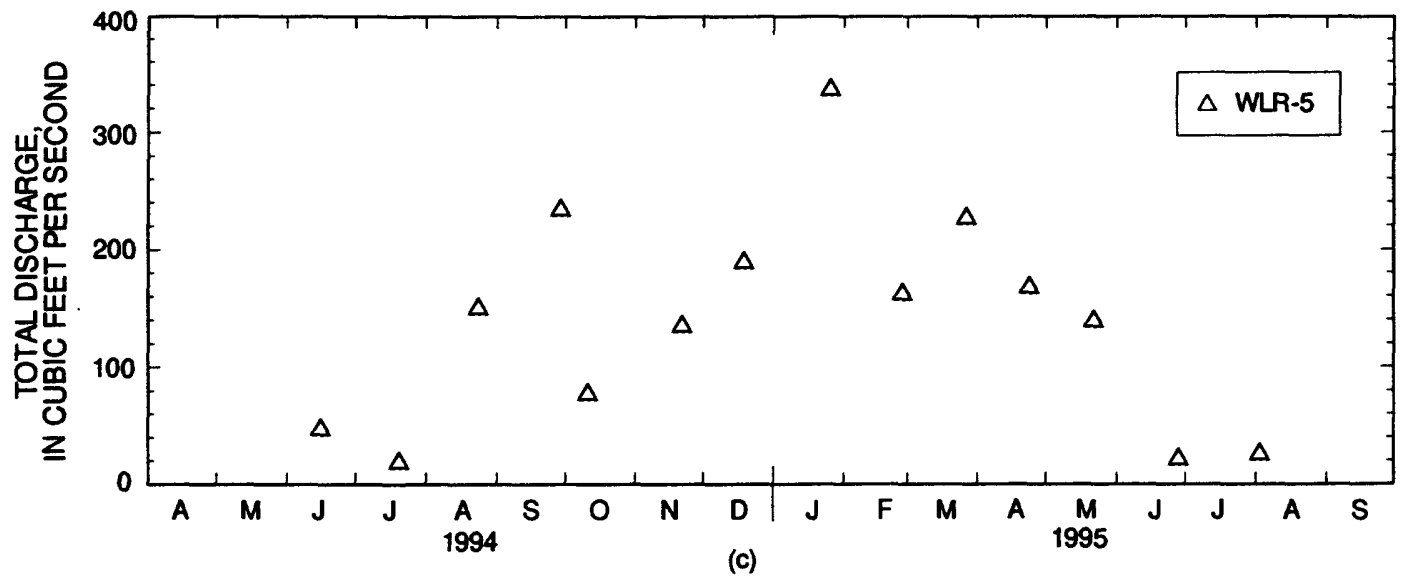

Figure 11. Change in streamflow-discharge in the Souhegan River in Milford, New Hampshire between: (a) WLR-1 and P-2, (b) WLR-5 and station 39, and (c) streamflow discharge at WLR-5. 
a)

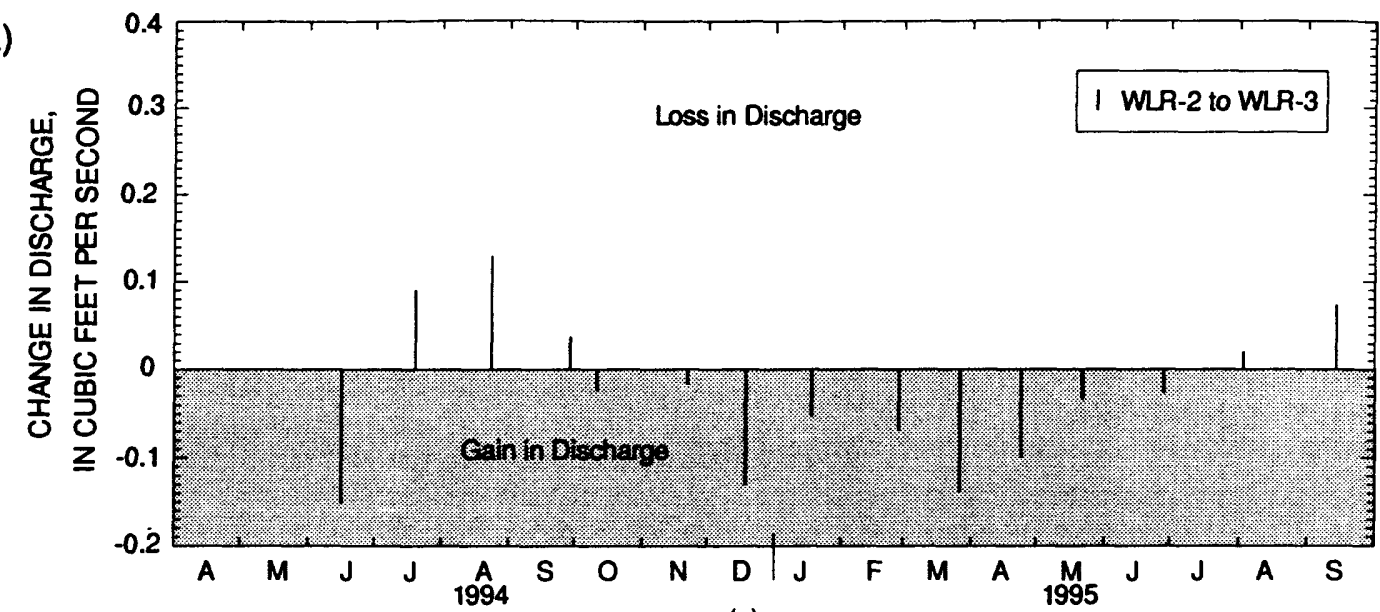

(a)

b)

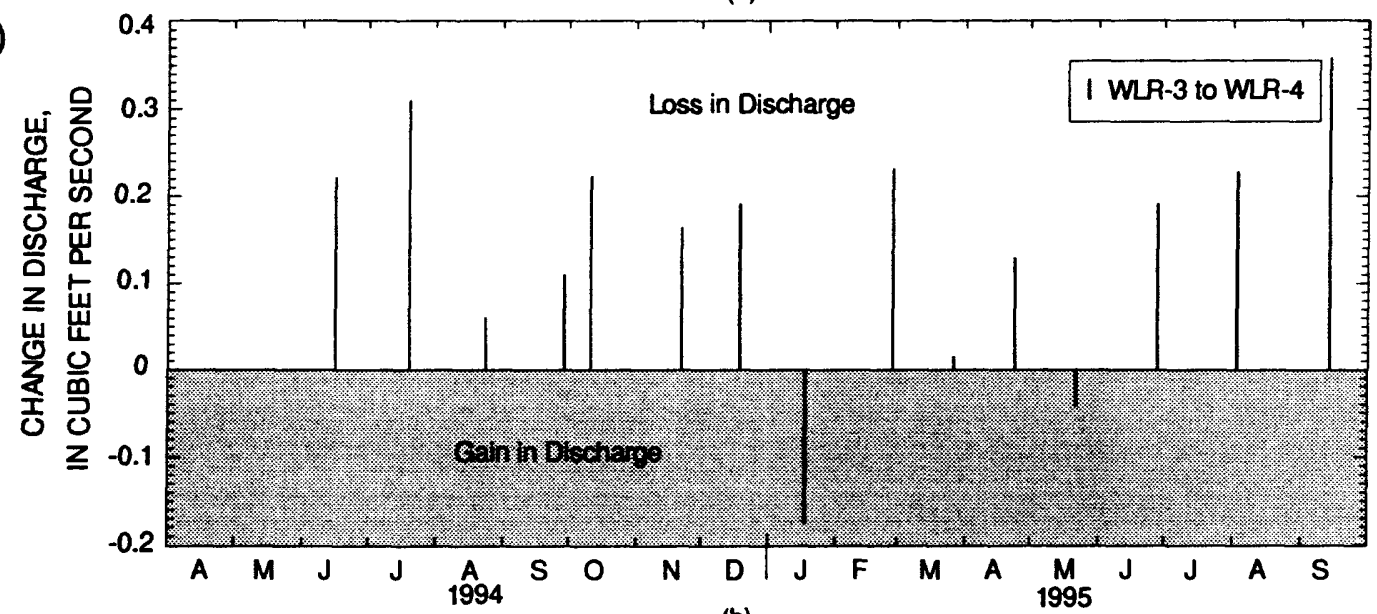

c)

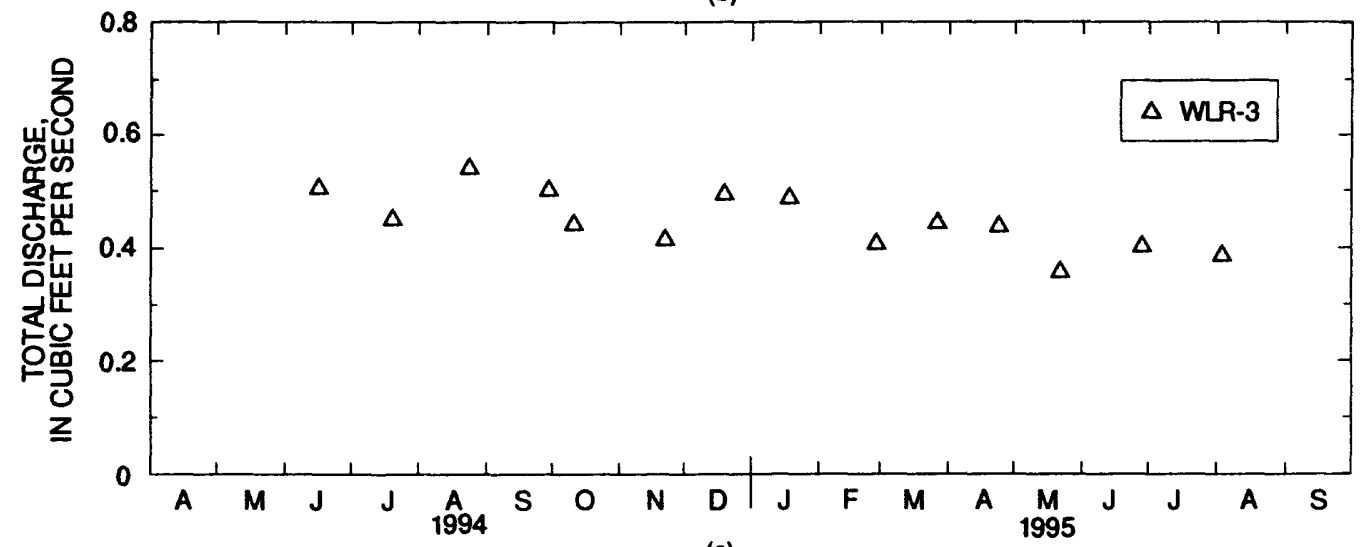

(c)

Figure 12. Change in streamflow-discharge in the discharge ditch in Milford, New Hampshire between: (a) WLR-2 and WLR-3, (b) WLR-3 and WLR-4, and (c) streamflow discharge at WLR-3. 
streamflow. For example, along the upstream reach of the Souhegan River between WLR-1 and P-2, the highest observed streamflow loss accompanied the highest streamflow during the fall and winter of 199495. Although the maximum potential loss or gain occurs during the highest discharge, a nonlinear relation is present between the actual amount of loss or gain and available streamflow. A good example is provided by the measurements from October 11,1994, when streamflow loss $\left(23.3 \mathrm{ft}^{3} / \mathrm{s}\right)$ and the percent of total streamflow loss ( 26 percent) were highest; the latter occurred on January 26,1995 , with a measured discharge of $297 \mathrm{ft}^{3} / \mathrm{s}$ at WLR-1 and a loss of $12 \mathrm{ft}^{3} / \mathrm{s}$ along the upper reach between WLR-1 and P-2 (a loss per streamflow ratio of 0.04 percent).

Although some clear tendencies are present for the investigated reaches, several factors must be recognized that can complicate the analysis of streamflow gains and losses. The first factor is inaccuracy in computed discharges, gains, and losses. The computed net gain or loss between two coupled stations is subject to a potential error of 10 percent for two excellent-rated measurements ( 5 percent each). Therefore, confidence that computed gains/losses are actual and not a function of measurement inaccuracies must be partly dependent on whether computed gains/losses exceed the 10 percent criteria for excellent-rated measurements, which applies to reaches on the Souhegan River, and 20 percent for good- to fair- rated measurements, which applies to reaches on the discharge ditch. Twenty percent of the computed gains/losses exceed the 10 percent criteria for the measurements on the Souhegan River (between WLR-1 and P-2, and between WLR-5 and station 39), and 33 and 66 percent of the computed gains/losses exceed the 20 percent criteria on the discharge ditch (between WLR-2 and WLR-3, and between WLR-3 and WLR-4). Of the 20 percent for measurements taken on the Souhegan River, losses only were computed for the upper reach (between WLR-1 and P-2) and gains only were computed for the downstream reach (between WLR-5 and station 39).

The second factors are time-dependent riveraquifer processes. Different river-aquifer processes occur at different times of the year because of climatic conditions and result in a non-linear system response. For example, some measurements were made during dry, low-flow conditions when ground-water recharge or discharge is the primary factor in gains or losses. During high-flow periods, processes such as overland runoff, interflow, and bank storage may affect streamflow gains or losses.

The last factor is variablity of streamflow during the time measurements were taken. Typically, it took 3 hours to measure discharge at two coupled stations. If variations in streamflow during the measurement exceeded the actual gain/loss along the river reach, then the computed gain/loss values reflect a time-series analysis of streamflow changes instead of streamflow gains/losses along a reach at a specified time. These three factors may account for the apparent oscillations between losing and gaining for the investigated reaches. Therefore, it is conceivable that reaches are consistently losing or gaining.

Data from this study showed that the upper reaches of the Souhegan River had streamflow losses during a range of streamflow conditions and not just during lowflow conditions, as was the focus of previous investigations (Harte and Mack, 1992). The magnitudes of streamflow losses/gains on the Souhegan River were generally greater when the average streamflow from the index stations (Stony Brook at Temple, Souhegan River at Merrimack, and Soucook River at Concord) was less than 70 percent exceedance (tables 4 and 5). Again, previous studies focused on measurements of streamflow losses/gains during low-flow conditions when streamflow durations were greater than 70 percent; therefore, streamflow losses/gains were underestimated.

Streamflow losses on the discharge ditch between stations WLR-3 and WLR-4 were generally less than those reported previously. Losses reached their minimum during fall and winter.

The areal pattern of losing and gaining streamflow reaches for the high-flow synoptic (table 6) is shown in figure $13 \mathrm{c}$, along with patterns for low-flow conditions (figs. 13a and 13b) from previous studies (Olimpio and Harte, 1994). During high-flow conditions, it was not possible to determine gains and losses on the main stem of the Souhegan River because of inaccuracies associated with taking discharge measurements during high-flow conditions. However, patterns of gain and loss were delineated on tributaries with relatively low discharges. A losing reach was measured on the unnamed tributary next to the State Fish Hatchery withdrawal wells during the high-flow synoptic. Reaches on Tucker Brook and the discharge ditch showed gains. One reach on Purgatory Brook showed a 
Table 6. Streamflow measurements from high-flow synoptic gaging stations, April 1994, Milford, New Hampshire

[Stage in feet above sea level; discharge in cubic feet per second; -, no data]

\begin{tabular}{|c|c|c|c|c|c|c|c|c|}
\hline \multirow{2}{*}{$\begin{array}{c}\text { Site } \\
\text { (figure 4) }\end{array}$} & \multirow{2}{*}{$\begin{array}{l}\text { Stream } \\
\text { or } \\
\text { river }\end{array}$} & \multicolumn{2}{|c|}{ April 12, 1994} & \multicolumn{2}{|c|}{ Aprll 13, 1994} & \multicolumn{3}{|c|}{ April 14, 1994} \\
\hline & & Discharge & Time & Dlscharge & Time & Discharge & Time & Stage \\
\hline 3 & Great Brook & - & -- & - & - & 56.0 & 1505 & - \\
\hline $7 \mathrm{~B}$ & Tucker Brook & -- & -- & 13.9 & 1015 & - & - & - \\
\hline 14 & Tucker Brook & -- & -- & 12.2 & 1050 & - & - & -- \\
\hline 15 & Purgatory Brook & - & - & 66.2 & 1320 & -- & - & - \\
\hline 17 & Discharge Ditch & 0.800 & 1445 & - & -- & - & - & - \\
\hline 18 & Discharge Ditch & .664 & 1400 & - & - & - & - & - \\
\hline 20 & Tucker Brook & -- & - & 13.8 & 0945 & - & - & - \\
\hline 21 & Souhegan River & -- & - & 5.68 & 1500 & - & - & - \\
\hline 23 & Purgatory Brook & - & - & 59.6 & 1205 & - & - & -- \\
\hline 24 & (no name) & .33 & 1632 & - & - & .33 & 1632 & - \\
\hline 25 & Purgatory Brook & - & - & 53.4 & 1255 & -- & - & - \\
\hline 26 & Tributary 2 & - & -- & 7.00 & 1500 & - & - & -- \\
\hline 27 & Tributary 2 & - & - & 7.27 & 1430 & - & - & - \\
\hline 29 & Tributary 1 & - & -- & 3.53 & 1645 & - & - & - \\
\hline $1_{30}$ & Tributary 1 & - & -- & 2.84 & 1625 & - & - & - \\
\hline 33 & Souhegan River & 688 & 1330 & - & -- & - & - & - \\
\hline 43 & Discharge Ditch & .436 & 1205 & - & - & - & - & - \\
\hline 44 & Discharge Ditch & .491 & 1235 & - & - & - & - & - \\
\hline 47 & Discharge Ditch & .200 & - & - & - & - & - & - \\
\hline 48 & Souhegan River & 569 & 0950 & - & -- & 704 & 1015 & - \\
\hline WLR-5 & Souhegan Ri ver & - & -- & -- & - & 812 & 1220 & 246.42 \\
\hline & & - & -- & -- & - & 847 & 1420 & 246.39 \\
\hline
\end{tabular}

' Station 30 is not shown on figure 4 but is located 2,000 feet upstream of gaging station 29.

gain of about $7 \mathrm{ft}^{3} / \mathrm{s}$. (approximately 12 percent of streamflow). A large reach of losing streamflow from the upstream reaches of the Souhegan River past the State Fish Hatchery wells was mapped during moderate and low streamflow (figs. 13a and 13b). The State Fish Hatchery well FH-4 (well number 87) induces large amounts of losing discharge and river infiltration to the aquifer (figs. 2, 13a, and 13b).

\section{Ground Water}

Ground-water levels from five continuously measured wells (July 1994 to July 1995) fluctuated up to 5 feet and responded similarly to hydrologic conditions (fig. 14). Water levels in all five wells rose to a maximum in December 1994 and were at a minimum during summer 1994. Ground-water data collected after July 1995 (not included in this report) show that water levels were lower than levels in the summer of 1994.
Ground-water levels from biweekly measurements (June 1994 to June 1995) were also at a maximum in December 1994 (appendixes 3 and 4) except at FH-5OBS1 (well number 240), which showed maximum water levels in June 1994. Well FH-5-OBS1 is $10 \mathrm{ft}$ away from the State Fish Hatchery withdrawal well FH5 (well number 208), and water levels at FH5-OBS1 are affected by variations in withdrawals at FH-5. In June 1994, withdrawals were temporarily stopped, which caused water levels to rise in well FH-5-OBS1 (Tom Givetz, New Hampshire Fish and Game, oral commun., 1997). Minimum water levels also were recorded in summer 1994. Because of the below average precipitation in the summer of 1995 (National Oceanic and Atmospheric Administration, written commun., 1995), water levels in late summer of 1995 were below those from the previous summer (P.T. Harte, U.S. Geological Survey, written commun., 1995).

Ground-water levels from biweekly measurements showed greatest fluctuations near areas 


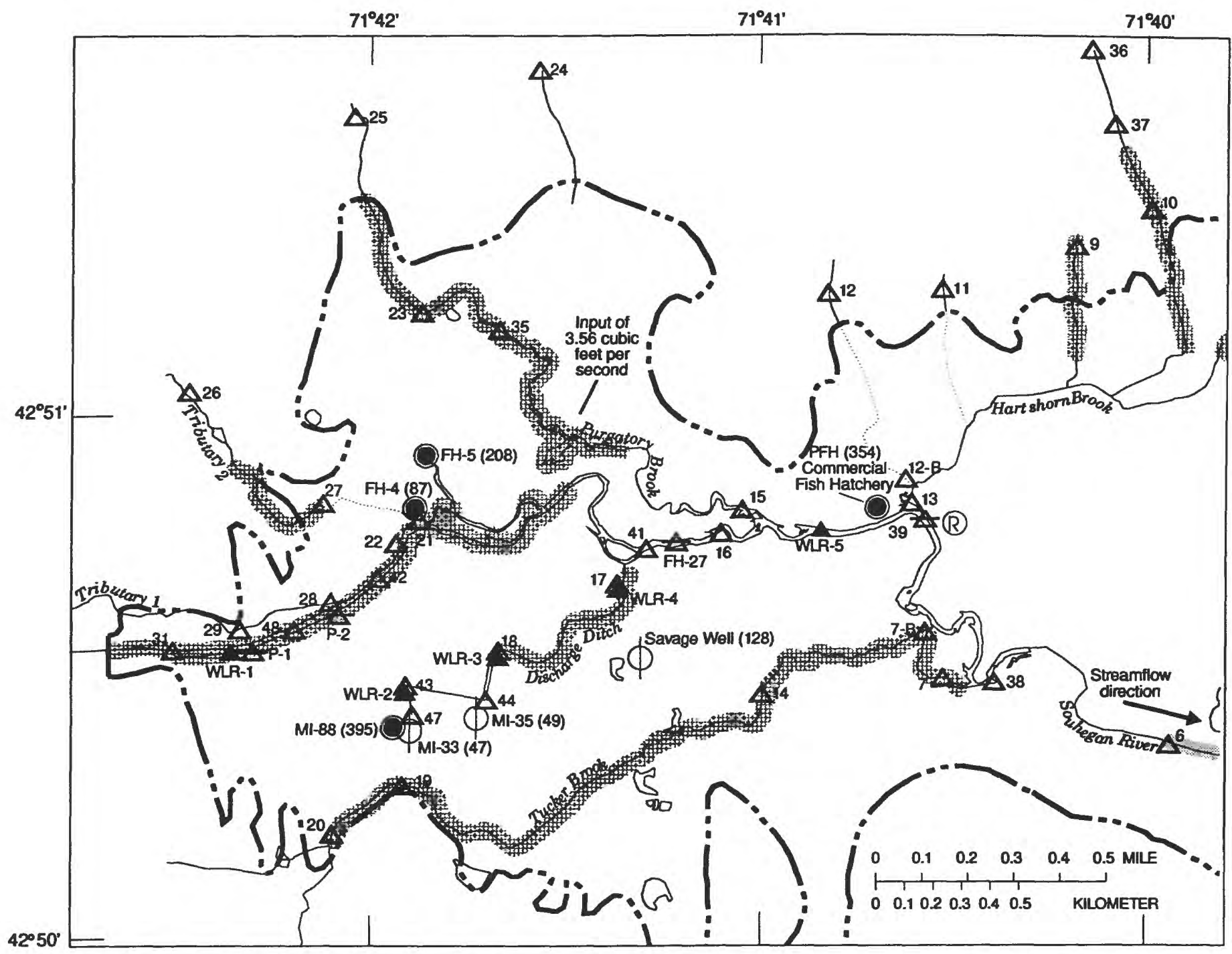

EXPLANATION

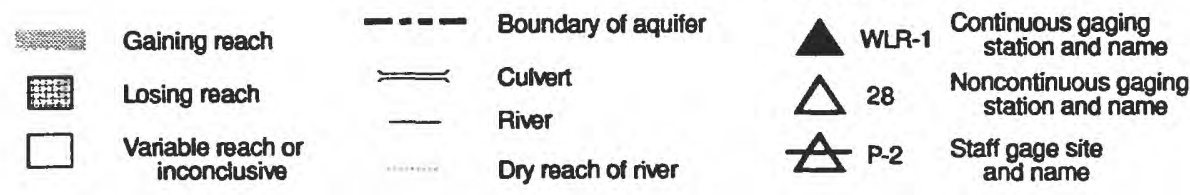

(R) Bedrock Outcrop

DMI-35 (49) Well name and number for

FH-4 (87) Well name and withdrawal wolls

Figure 13a. Patterns of change in streamflow-discharge in Milford, New Hampshire from low-fiow conditions, October 1988. (Note: During June 1988, streamfiow gains were measured between stations 16 and 6)

of ground-water withdrawals (table 7; appendixes 3 and 4). A maximum fluctuation of $16.47 \mathrm{ft}$ was measured at an observation well (FH-5-OBS1; well number 240) adjacent to the State Fish Hatchery withdrawal well, FH-5 (fig. 7; well number 208). Fluctuations of this magnitude are caused by the expansion and contraction of the cone of depression around the withdrawal well. The expansion and contraction of the cone of depression is caused by variations in withdrawals and in ground-water recharge. Observations of water levels in well FH-5 during withdrawals show quick response to recharge from precipitation (Tom Givetz, New Hampshire Fish and Game, oral commun., 1997). Most ground-water levels fluctuated between 2 and $5 \mathrm{ft}$ ( 60 out of 87 wells). Ground-water levels fluctuated the least, less than $2 \mathrm{ft}$, in wells located in the central part of 


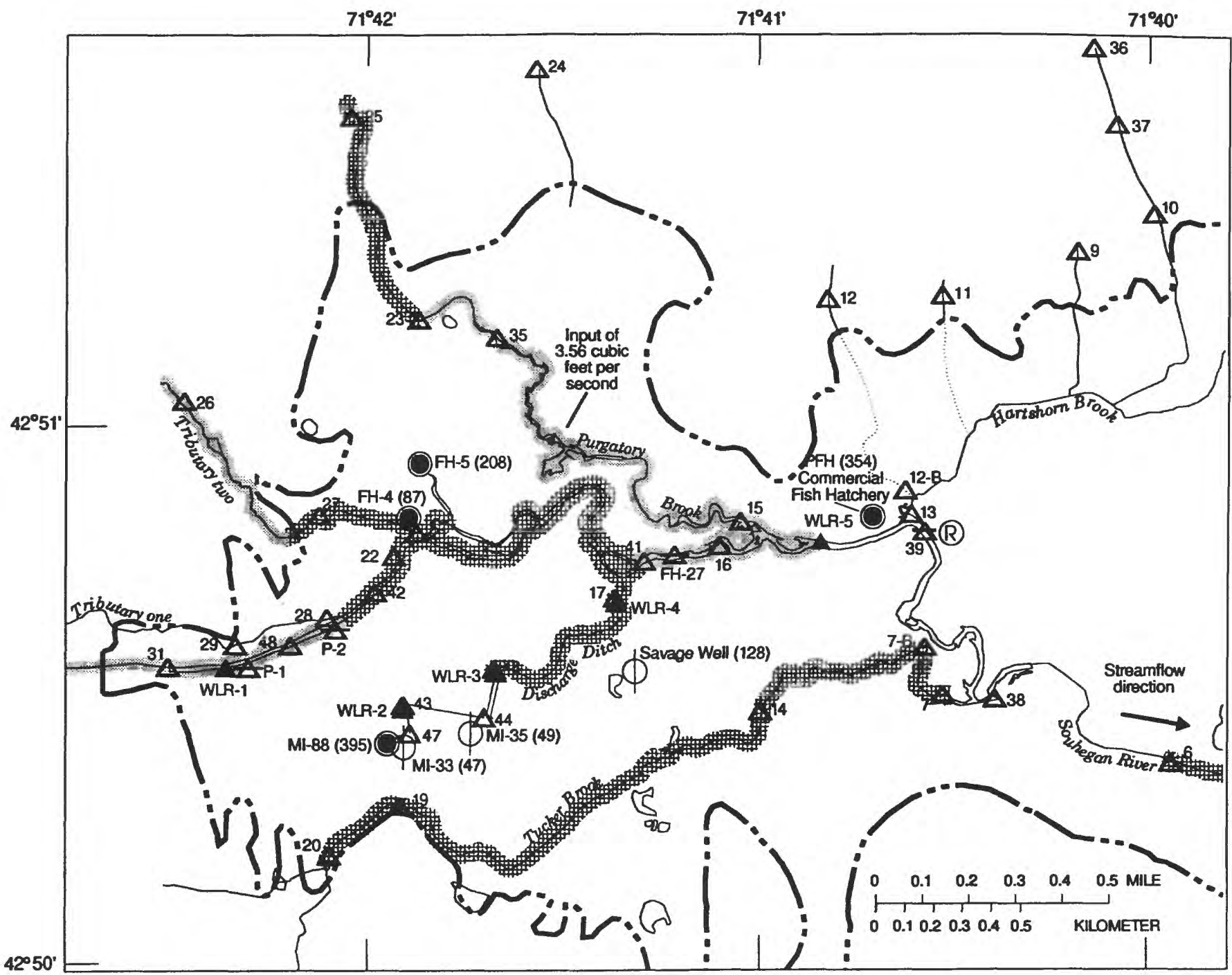

EXPLANATION

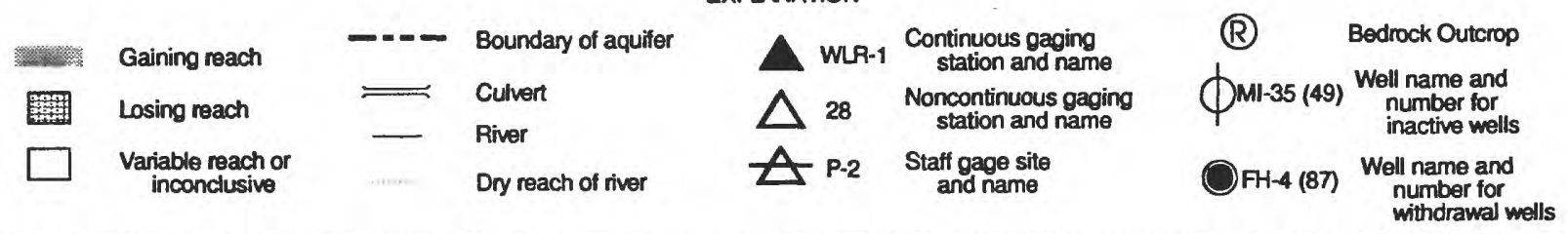

Figure 13b. Patterns of change in streamflow-discharge in Milford, New Hampshire from medium-flow conditions, October 1990.

the MSGD plume (fig. 2). The central part of the contaminant plume is centrally located between a recharge zone at the upper reaches of the Souhegan River and a discharge zone at the middle reaches of the Souhegan River. The central zones of a flow system typically have the least fluctuations of water levels (Toth, 1962). In recharge zones, ground-water levels are affected by variations in recharge to the aquifer from river leakage and precipitation recharge. In discharge zones, ground-water levels are affected by the amount of river-stage fluctuations; therefore, where river-stage fluctuations increase, so will fluctuations increase in ground-water levels.

Vertical hydraulic gradients seem to be relatively constant throughout the year. Water levels at well clusters (wells grouped together and screened at different depths) closely followed each other (appendix 

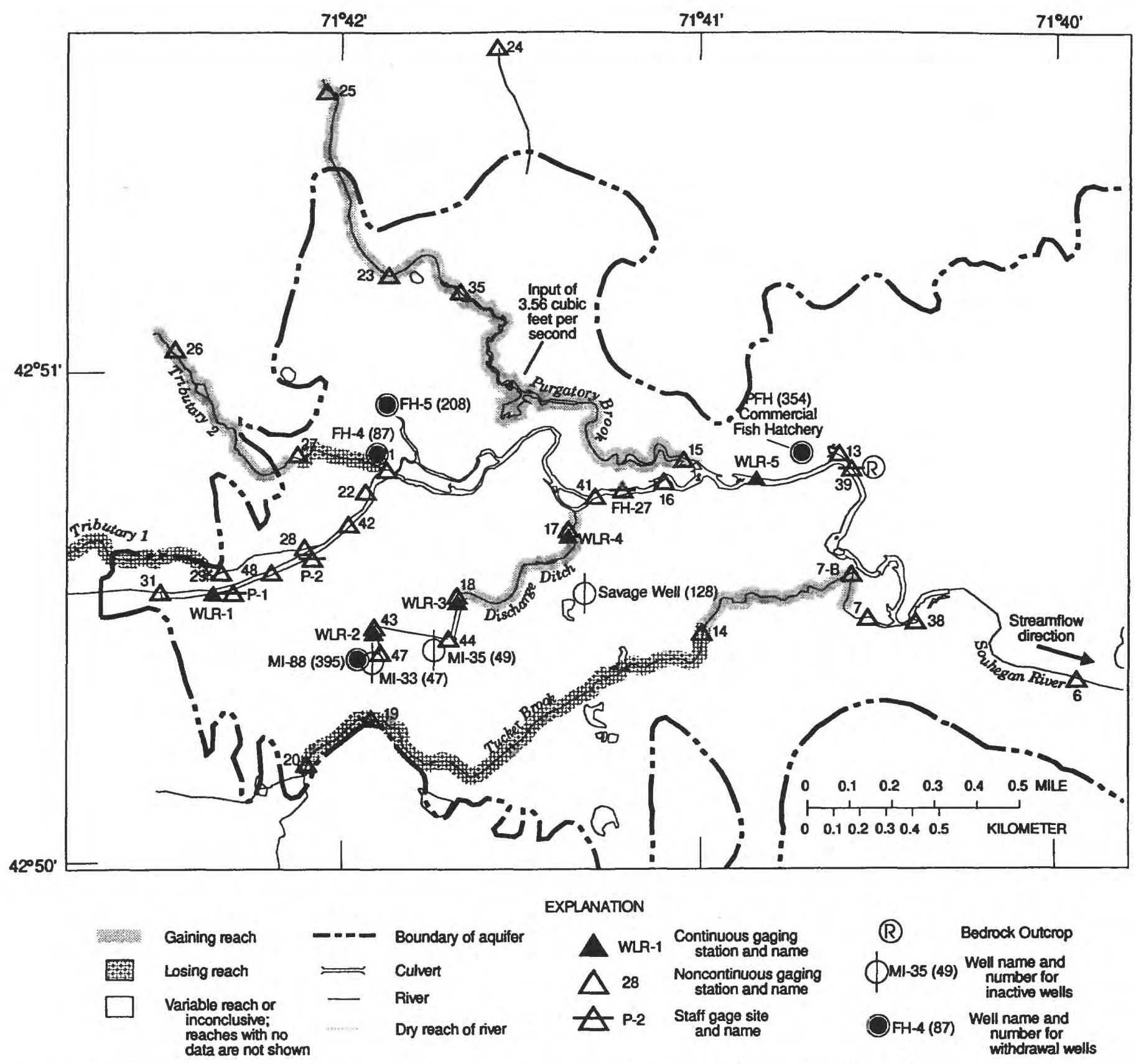

EXPLANATION

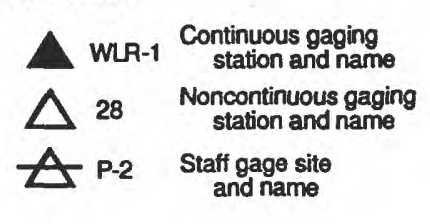

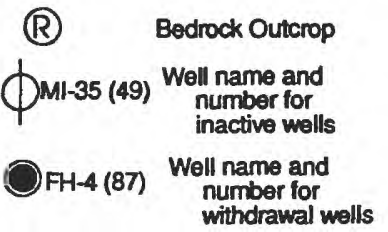

Figure 13c. Patterns of change in streamflow-dlscharge in Milford, New Hampshire from high-flow conditions, April 1994.

4), and generally maintain a consistent head difference.

Apparent hydraulic gradients computed along transects from biweekly measurements of water levels show transient variations in gradients throughout the period of measurement (June 1994 to June 1995). Gradients along some transects varied more than others (fig. 15). Transects that extend closest to the till-aquifer boundary (fig. 7, B'-B, and C-C'), showed larger ranges in hydraulic gradients than other transects. Hydraulic gradients along E-E', which correspond to the longitudinal axis of the plume, were fairly constant $(0.075 \mathrm{ft} / \mathrm{ft})$ except in December 1994. Hydraulic gradients along transects parallel to the plume were appreciably less but varied more than longitudinal hydraulic gradients. The variation in transverse hydraulic gradients from seasonal variations throughout 


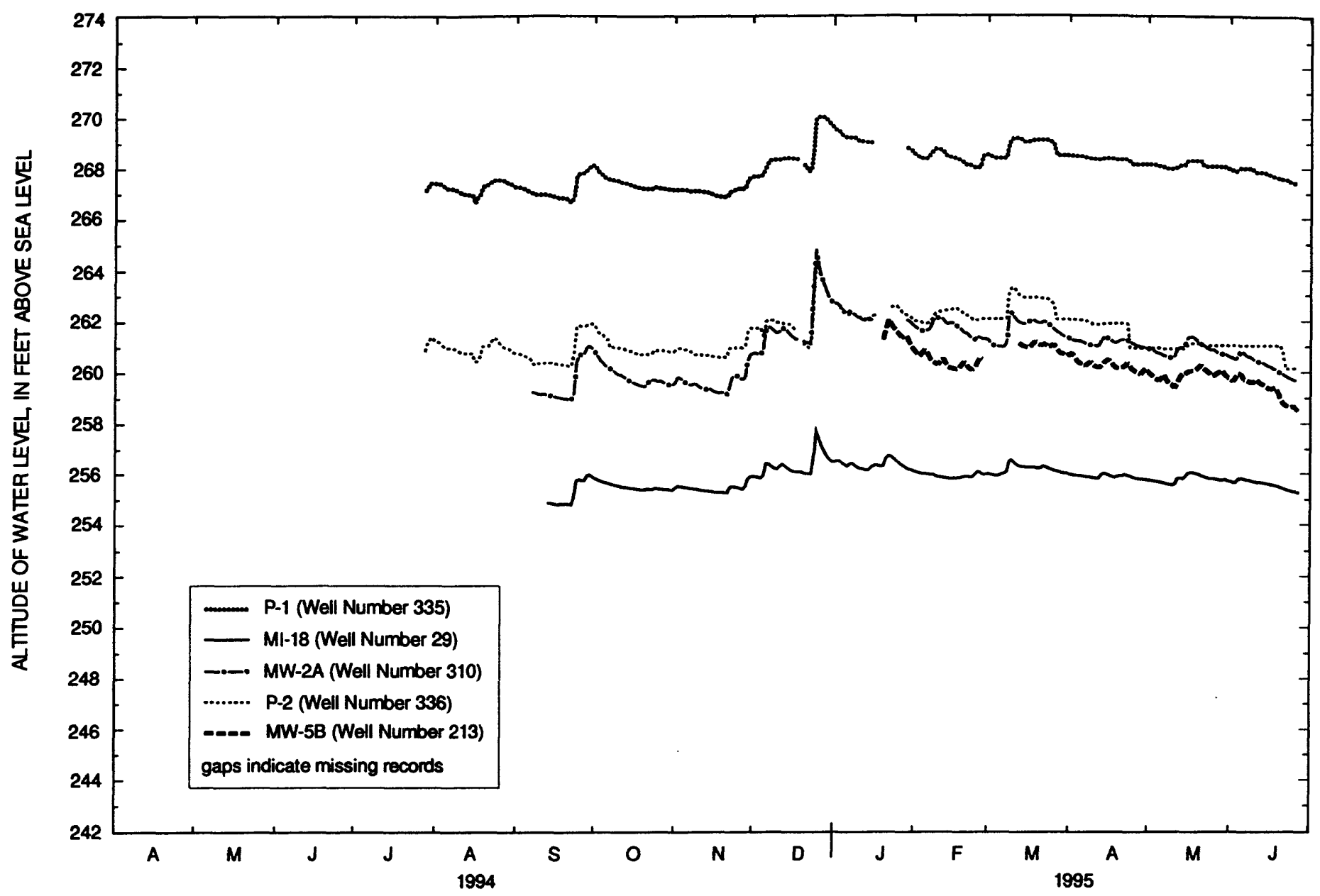

Figure 14. Continuous dally mean ground-water levels for wells P-1, P-2, MI-18, MW-2A, and MW-5B In Milford, New Hampshire.

the year has probably enhanced lateral disbursement of contaminants.

The fluctuation in direction of hydraulic gradients along F'-F between MW-33 and FH-27, near the confluence of Purgatory Brook and the Souhegan River, may partly explain distribution of contaminants in this area (fig. 2). The direction of hydraulic gradients changed direction with gradients sloping toward Purgatory Brook most of the year. For the remaining part of the year, gradients sloped toward the Souhegan River. The contaminant plume appears to be affected by the predominant direction of the gradient and is heading northeasterly toward Purgatory Brook (fig. 2).

Maximum ground-water hydraulic gradients (table 8) from triangular grouping of wells, or three-point planar solution of water levels, showed the largest seasonal variability in the direction of maximum gradient and magnitude of slope in areas adjacent to losing river reaches by the contaminant source area (fig. 16; triangles $A, B$, and $C$ ), by ground-water withdrawals (fig. 16; triangles $D$ and $M$ ), and by the leading edge of the contaminant plume (fig. 16; triangles $\mathrm{J}$ and $\mathrm{E}$ ). Most variability is attributed to areal and temporal differences in river fluctuations and variations in source areas to withdrawal wells as the result of variations in withdrawals and seasonal recharge. River-stage fluctuations adjacent to well P-2 (well number 336) were $0.5 \mathrm{ft}$ greater than river-stage fluctuations adjacent to well P-1 (well number 335) over the same time period; this difference in fluctuation caused directional changes in maximum gradients for triangles $\mathrm{A}$ and $\mathrm{B}$. Seasonal variations in ground-water withdrawals and recharge caused the expansion and contraction of the cone of depression around the withdrawal wells. Maximum gradient changes resulted in triangle $D$, which contains the State Fish Hatchery withdrawal wells (well numbers 208 and 87). 
Table 7. Ground-water-level fluctuations for wells measured biweekly (June 1994June 1995), Milford, New Hampshire

[Fluctuations in feet; incomplete data for wells: MW-16R, P-2, MI-19, MW-15A, MW-15B, HM-1, MI-32, MI-21A, MI-27, MW-21, MI-20A, PZ1003, MW-2A, P-16. Well locations are shown on plate 1]

\begin{tabular}{|c|c|c|c|c|c|}
\hline Well Number & Well name & Fluctuation & Well Number & Well name & Fluctuation \\
\hline \multicolumn{3}{|c|}{ Water-level fluctuations greater than 5 feet } & \multicolumn{3}{|c|}{ Water-level fluctuations between 3 and 4 feet } \\
\hline 240 & FH-5-OBS1 & 16.47 & 322 & MW-17B & 3.18 \\
\hline 86 & FH-13-OBS1 & 13.52 & 323 & MW-17C & 3.16 \\
\hline 348 & MW-6A & 5.10 & 285 & SPZ-1 & 3.97 \\
\hline \multicolumn{6}{|c|}{ Water-level fiuctuations between 4 and 5 feet } \\
\hline $\begin{array}{r}228 \\
23 \\
306 \\
318 \\
311 \\
366\end{array}$ & $\begin{array}{l}\text { MW-3 } \\
\text { MI-10 } \\
\text { FH-27 } \\
\text { MW-11A } \\
\text { MW-2R } \\
\text { MW-30 }\end{array}$ & $\begin{array}{l}4.02 \\
4.31 \\
4.06 \\
4.16 \\
4.10 \\
4.59\end{array}$ & $\begin{array}{l}279 \\
296 \\
297\end{array}$ & $\begin{array}{l}\text { SPZ-2 } \\
\text { MW-32A } \\
\text { MW-32B }\end{array}$ & $\begin{array}{l}3.42 \\
3.07 \\
3.08\end{array}$ \\
\hline \multicolumn{3}{|c|}{ Water-tevel fiuctuations between 3 and 4 feet } & \multicolumn{3}{|c|}{ Water-level fluctuations between 2 and 3 feet } \\
\hline $\begin{array}{r}307 \\
209 \\
25 \\
212 \\
312\end{array}$ & $\begin{array}{l}\text { MW-1A } \\
\text { MW-1C } \\
\text { Ml-12 } \\
\text { MW-4B } \\
\text { MW-4A }\end{array}$ & $\begin{array}{l}3.23 \\
3.27 \\
3.71 \\
3.85 \\
3.86\end{array}$ & $\begin{array}{r}309 \\
21 \\
169 \\
30 \\
31\end{array}$ & $\begin{array}{l}\text { MW-1B } \\
\text { Ml-7 } \\
\text { Ml-4 } \\
\text { MI-19 } \\
\text { Ml-20 }\end{array}$ & $\begin{array}{l}2.16 \\
2.41 \\
2.27 \\
2.90 \\
2.48\end{array}$ \\
\hline $\begin{array}{l}347 \\
292 \\
214 \\
314 \\
215\end{array}$ & $\begin{array}{l}\text { MW-4R } \\
\text { FH-30 } \\
\text { MW-6B } \\
\text { MW-7A } \\
\text { MW-7B }\end{array}$ & $\begin{array}{l}3.86 \\
3.10 \\
3.76 \\
3.71 \\
3.49\end{array}$ & $\begin{array}{r}216 \\
351 \\
41 \\
352 \\
217\end{array}$ & $\begin{array}{l}\text { MW-8B } \\
\text { MW-9A } \\
\text { MI-26 } \\
\text { MW-9B } \\
\text { MW-9C }\end{array}$ & $\begin{array}{l}2.91 \\
2.64 \\
2.25 \\
2.42 \\
2.41\end{array}$ \\
\hline $\begin{array}{r}315 \\
35 \\
38 \\
40 \\
42\end{array}$ & $\begin{array}{l}\text { MW-8A } \\
\text { Ml-22 } \\
\text { Ml-24 } \\
\text { Ml-25 } \\
\text { MI-27 }\end{array}$ & $\begin{array}{l}3.06 \\
3.99 \\
3.41 \\
3.90 \\
3.78\end{array}$ & $\begin{array}{l}220 \\
320 \\
349 \\
341 \\
281\end{array}$ & $\begin{array}{l}\text { MW-12A } \\
\text { MW-12B } \\
\text { MW-14A } \\
\text { MW-14B } \\
\text { MW-34 }\end{array}$ & $\begin{array}{l}2.04 \\
2.04 \\
2.24 \\
2.37 \\
2.34\end{array}$ \\
\hline $\begin{array}{r}43 \\
316 \\
203 \\
317 \\
218\end{array}$ & $\begin{array}{l}\text { MI-28 } \\
\text { MW-10A } \\
\text { MI-63 } \\
\text { MW-10B } \\
\text { MW-10C }\end{array}$ & $\begin{array}{l}3.78 \\
3.22 \\
3.62 \\
3.21 \\
3.00\end{array}$ & $\begin{array}{l}222 \\
326 \\
327 \\
293 \\
294\end{array}$ & $\begin{array}{l}M W-14 R \\
M W-19 A \\
M W-19 B \\
M W-22 A \\
M W-22 B\end{array}$ & $\begin{array}{l}2.01 \\
2.36 \\
2.17 \\
2.63 \\
2.63\end{array}$ \\
\hline 218 & & & \multicolumn{3}{|c|}{ Water-level fluctuations less than 2 feet } \\
\hline $\begin{array}{l}210 \\
319 \\
219 \\
233 \\
321\end{array}$ & $\begin{array}{l}M W-2 B \\
M W-11 B \\
M W-11 R \\
M W-16 A \\
M W-16 B\end{array}$ & $\begin{array}{l}3.71 \\
3.92 \\
3.61 \\
3.59 \\
3.58\end{array}$ & $\begin{array}{l}308 \\
221 \\
225 \\
306 \\
264\end{array}$ & $\begin{array}{l}\text { MW-13A } \\
\text { MW-13B } \\
\text { MW-28 } \\
\text { MW-33 } \\
\text { MW-20A }\end{array}$ & $\begin{array}{l}1.66 \\
1.64 \\
1.64 \\
1.79 \\
1.49\end{array}$ \\
\hline $\begin{array}{l}344 \\
288 \\
258\end{array}$ & $\begin{array}{l}\text { MW-16C } \\
\text { PFH (OBS6) } \\
\text { MW-17A }\end{array}$ & $\begin{array}{c}3.47 \\
3.01 \\
3.17\end{array}$ & $\begin{array}{l}328 \\
255 \\
333\end{array}$ & $\begin{array}{l}M W-20 B \\
M W-24 A \\
M W-24 B\end{array}$ & $\begin{array}{l}1.50 \\
1.78 \\
1.75\end{array}$ \\
\hline
\end{tabular}




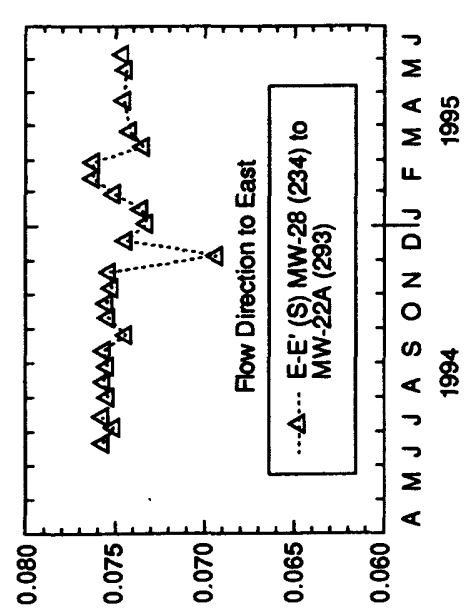

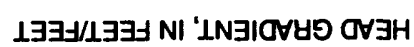

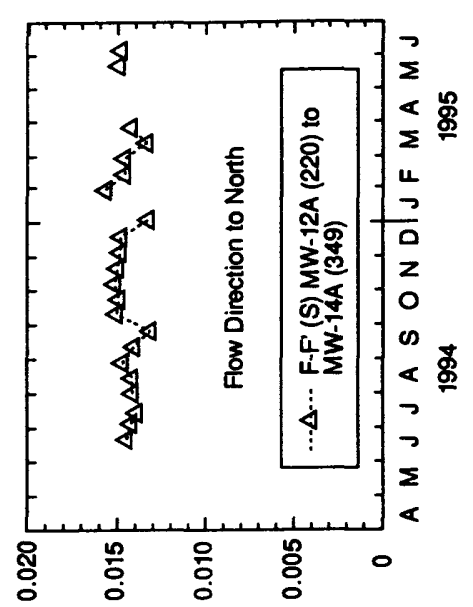

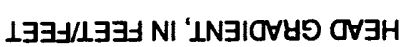

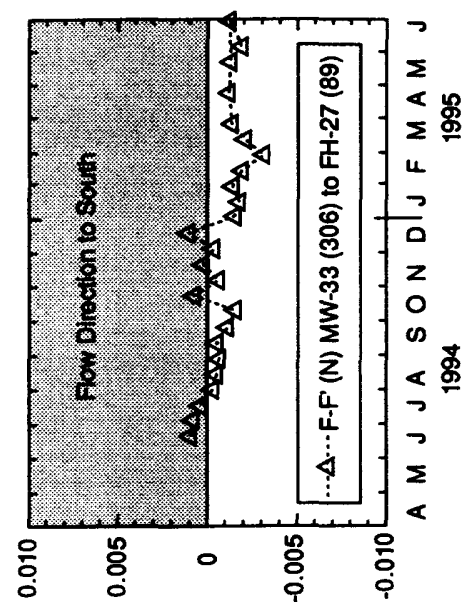

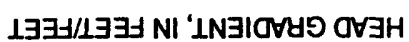

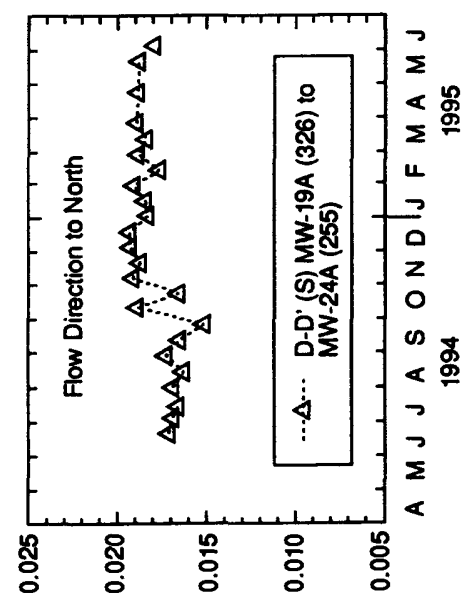

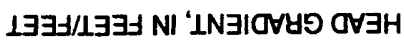

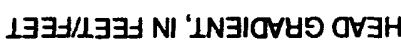

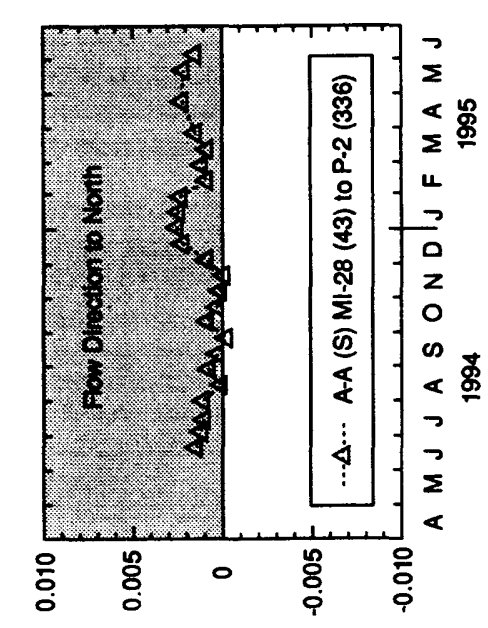

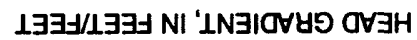

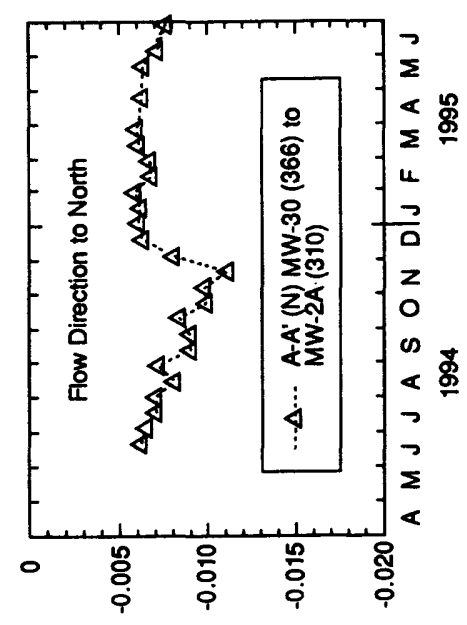

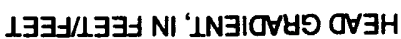

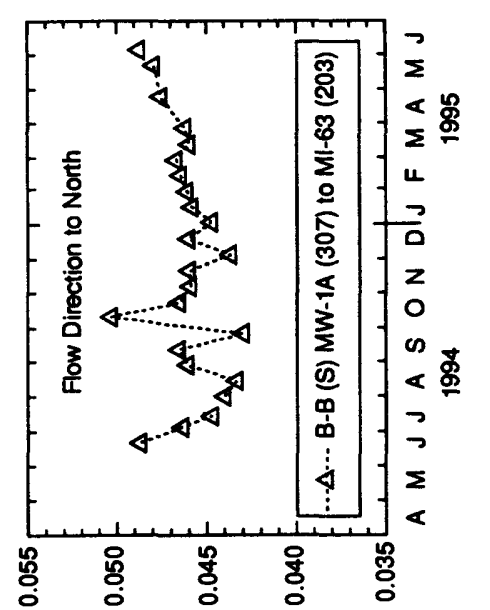

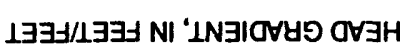

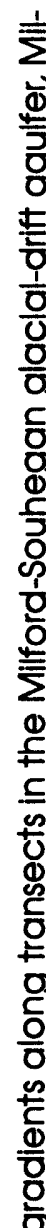

$\frac{0}{3}$

항

I

(1)

3

드

ㅇ

ธิ

步

을

응 으

주노

เ 3

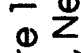

宁

क्ष" 
Table 8. Summary statistics on direction of maximum ground-water hydraulic gradients, and magnitude of slope of gradient from triangular grouping of wells, Milford, New Hampshire

[Triangles listed from maximum to minimum changes in direction and slope. Triangle locations are shown in figure 16.]

\begin{tabular}{|c|c|c|c|c|c|}
\hline \multicolumn{3}{|c|}{ Direction of maximum ground-water gradient } & \multicolumn{3}{|c|}{ Slope of maximum ground-water gradient } \\
\hline Triangle & $\begin{array}{l}\text { Mean direction, in } \\
\text { degrees from true } \\
\text { north }\end{array}$ & $\begin{array}{l}\text { Standard } \\
\text { deviation }\end{array}$ & Triangle & $\begin{array}{c}\text { Mean slope, In } \\
\text { feet per feet }\end{array}$ & $\begin{array}{l}\text { Standard } \\
\text { deviation }\end{array}$ \\
\hline $\mathbf{M}$ & 86.3 & 50.9 & D & 0.537 & 0.113 \\
\hline $\mathbf{J}$ & 77.2 & 33.9 & B & .429 & .084 \\
\hline B & 131.5 & 4.3 & $\mathbf{M}$ & .206 & .078 \\
\hline D & 11.0 & 9.4 & $\mathbf{A}$ & .401 & .056 \\
\hline $\mathbf{H}$ & 52.3 & 5.6 & $\mathbf{J}$ & .131 & .032 \\
\hline E & 86.8 & 5.1 & E & .207 & .026 \\
\hline $\mathrm{C}$ & 75.5 & 4.3 & $\mathbf{N}$ & .223 & .020 \\
\hline $\mathbf{A}$ & 125.4 & 4.1 & $\mathbf{H}$ & .258 & .018 \\
\hline $\mathbf{N}$ & 82.0 & 3.2 & $\mathbf{K}$ & .184 & .011 \\
\hline G & 67.9 & 2.9 & G & .142 & .008 \\
\hline 1 & 31.2 & 2.5 & I & .177 & .007 \\
\hline K & 52.8 & 2.2 & $\mathbf{F}$ & .196 & .007 \\
\hline $\mathbf{F}$ & 48.9 & 2.1 & L & .191 & .006 \\
\hline L & 53.8 & 1.6 & C & .273 & .003 \\
\hline
\end{tabular}

Changes in altitude of the water-table surface appear largest near the edges of the till-aquifer boundary between low-flow (figs. 17a and 17b) and high-flow synoptic (fig. 17c) measurements. Groundwater levels for synoptic events are given in appendix 5 . Water-table surface increased by more than $5 \mathrm{ft}$ along edges of the aquifer, as noted by the position of the 260foot contour (fig. 17). These results support results of computed gradients from biweekly wells that show greater variability along the edges of the aquifer.

The average difference between ground-water levels from the three synoptic events is shown in table 9 and indicates that the ground-water levels for high-flow conditions average $4 \mathrm{ft}$ higher than ground-water levels for low-flow conditions. Differences in water level were at a maximum at FH-5-OBS1 (well number 240) adjacent to the State Fish Hatchery withdrawal well (well number 208).

Comparison of biweekly (June 1994 to June 1995) and continuous water-level (June 1994 to July 1995) data with water levels measured during synoptic events provide some understanding of hydrologic conditions at the time of measurement of each data set. High water levels were observed during the April 1994 synoptic event, exceeding those measured during biweekly measurements (June 1994 to June 1995) and previous synoptic water levels in October 1988 and 1990. The mean water level for biweekly measurements is about $1 \mathrm{ft}$ higher than the October 1988 synoptic (tables 9 and 10) and about $0.5 \mathrm{ft}$ higher than the October 1990 synoptic (table 10). The October 1988 synoptic values are comparable to minimum water levels from biweekly measurements (appendix 3).

\section{Surface-Water and Ground-Water Interactions}

River stages and ground-water levels similarly respond to seasonal climatic trends but slightly differ in response to individual climatic events, such as rainstorms. River stage at gaging station WLR-1 and ground-water levels at nearby well P-1 (well number 


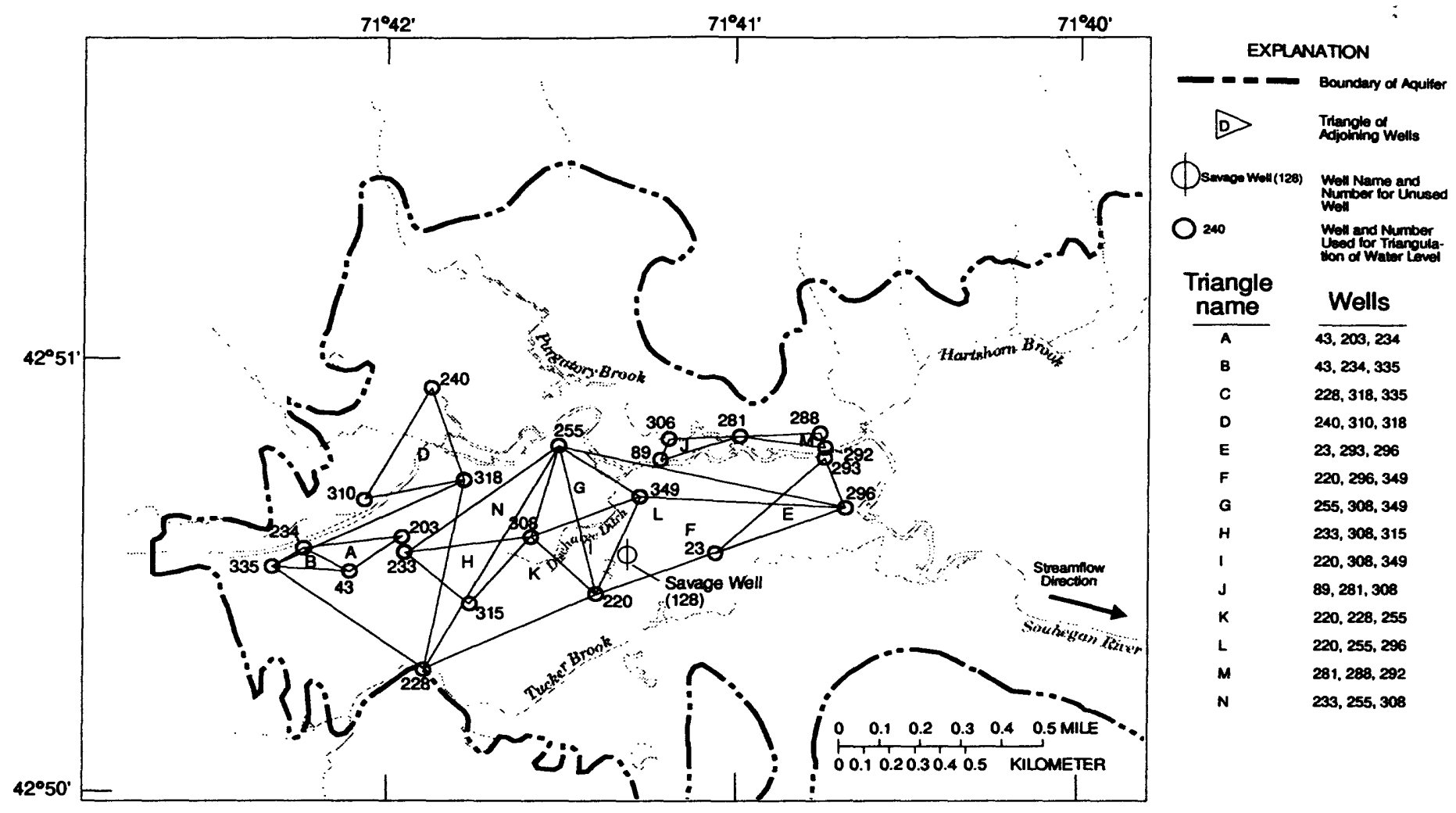

Figure 16. Triangular grouping of biweekly measured wells for determination of true ground-water-hydraulic gradients, Milford, New Hampshire.

335) show similar responses (fig. 18). Ground-water levels fluctuated slightly less and were less sensitive to short-term (few days) climate changes than river stage on the Souhegan River.

It is difficult to determine whether ground-water levels are responding to river-stage fluctuations or are responding to the same climatic event that caused river stage changes. Precipitation events, which cause increases in stage and ground-water levels, or dry periods, which cause decreases in stage and water levels, may simultaneously affect river stage and ground-water levels. Therefore, it is unclear if ground water levels are responding to changes in river stage or the precipitation event. However, ground-water levels are probably responding to the climatic event or seasonal period itself, as well as fluctuations in river stage. On several occasions, hydroelectric operations upstream of the study area caused short-term river-stage fluctuations over several hours during dry periods. Continuous recordings of ground-water levels at wells adjacent to the river showed a 10 percent change in ground-water levels relative to change in river stage during periods of change in river stage from upstream hydroelectric operations.
Directions in hydraulic gradients between river stages and adjacent ground-water levels were fairly constant (fig. 19). Sites where ground-water levels are lower than surface-water levels have negative hydraulic gradients and, conversely, sites where ground-water levels are more than river stage have positive hydraulic gradients. Negative gradients indicate a potential recharge to the aquifer. Either negative or positive gradients are maintained at all sites for the period measured (fig. 19).

At locations where the river loses water to the aquifer ( $\mathrm{P}-1, \mathrm{P}-2$, and $\mathrm{MW}-2 \mathrm{~A})$, gradients were at a maximum $(0.04 \mathrm{ft} / \mathrm{ft})$ in November and December 1994 and at a minimum value $(0.004 \mathrm{ft} / \mathrm{ft})$ in April 1995. At most locations where the river gains ground water (MW-22A, FH-27, and SPZ-2), maximum gradients $(0.045 \mathrm{ft} / \mathrm{ft})$ occurred in September 1994 and minimum gradients $(0.0 \mathrm{ft} / \mathrm{ft})$ in October-November 1994 . The variability of hydraulic gradients at losing or gaining sections of the river is attributed to differences in response times of surface and ground waters to inputs of water from precipitation or snowmelt. At river losing locations, river stages can rise more quickly than ground waters and cause an increase in surface to 


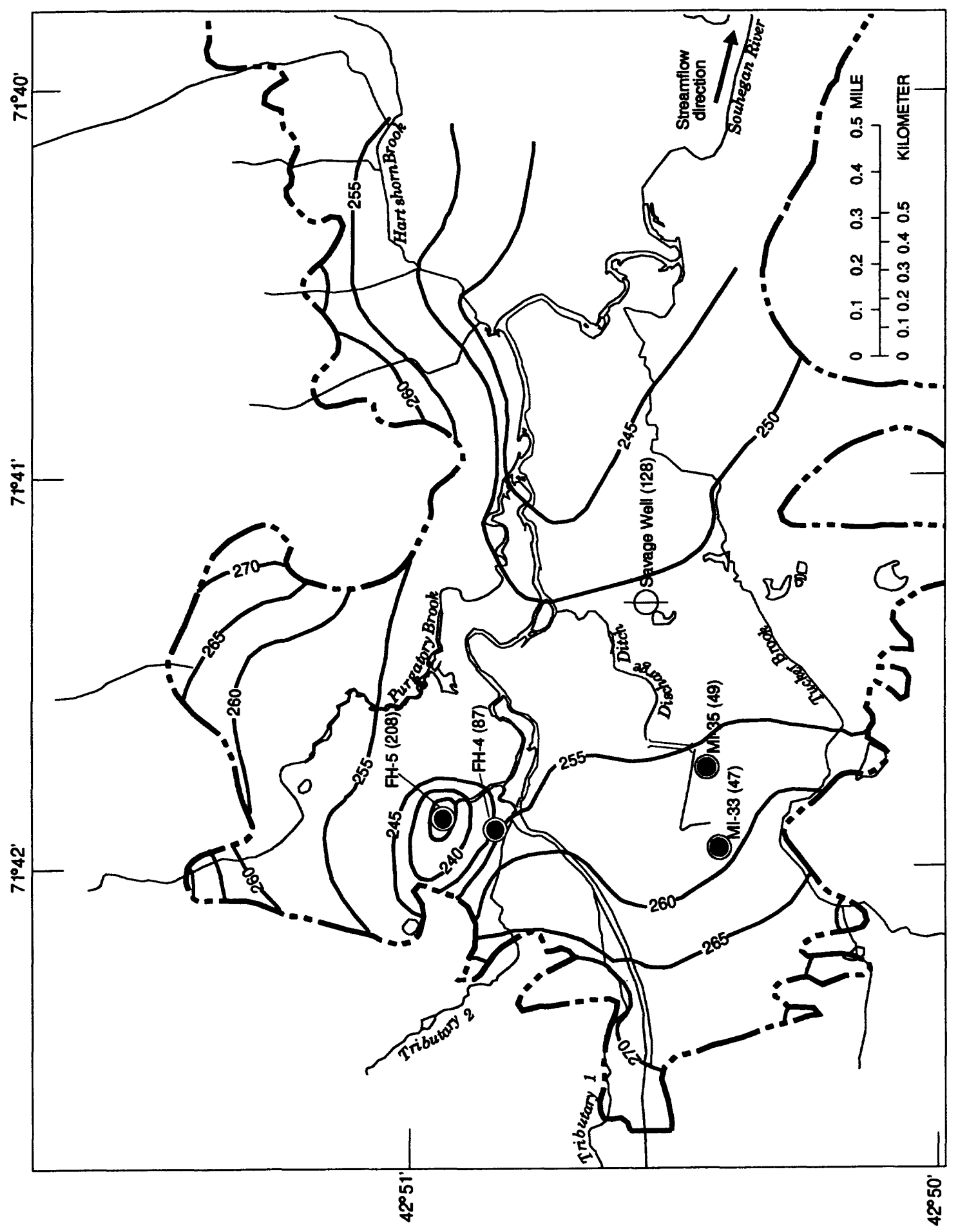

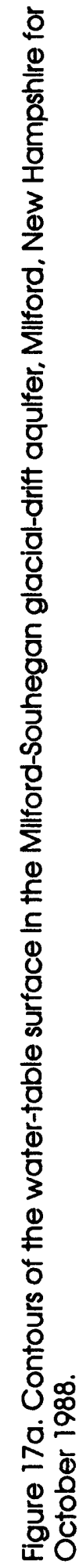




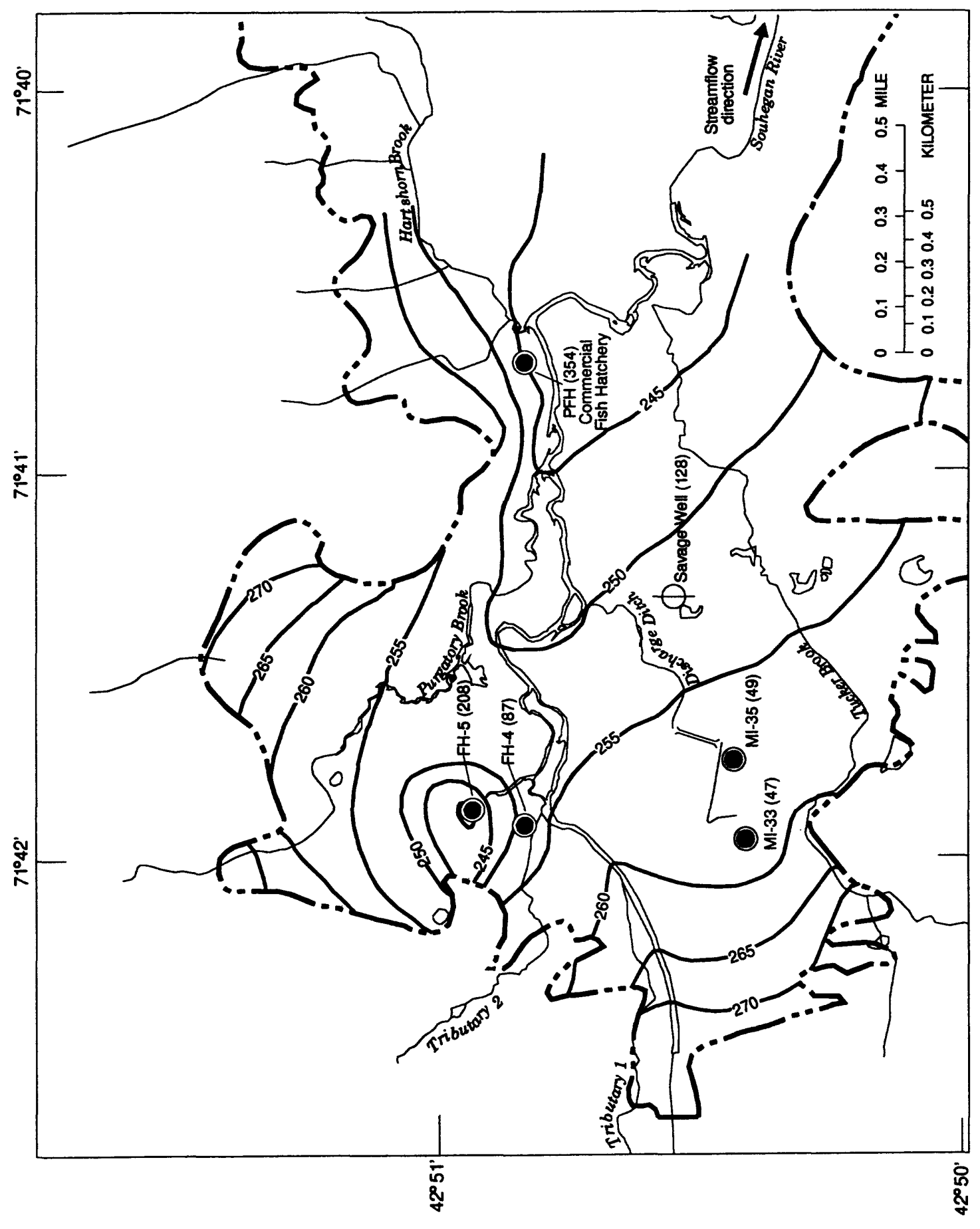

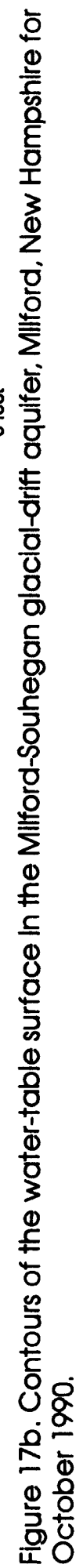




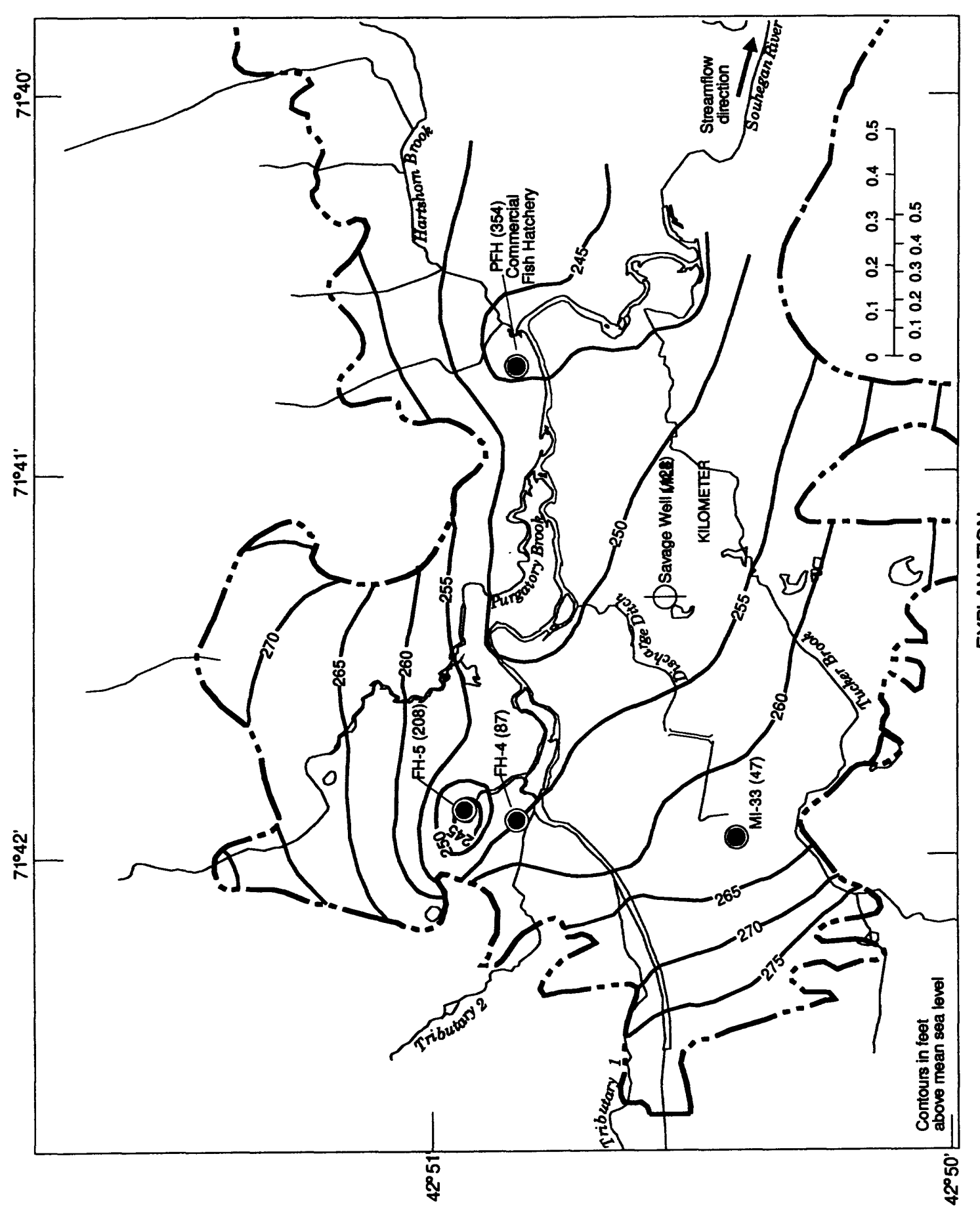

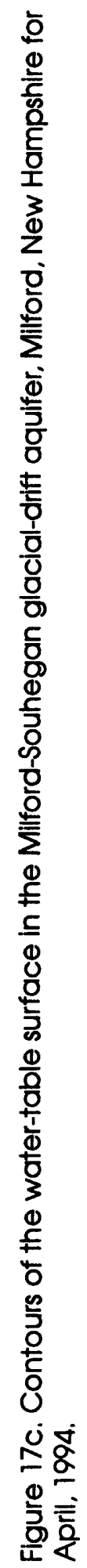


Table 9. Summary of differences in ground-water levels between synoptic events in October 1988, October 1990, and April 1994, Milford, New Hampshire

[All units in feet. Negative value indicates water level is greater than previous water level]

\begin{tabular}{lccc}
\hline & \multicolumn{3}{c}{ Difference in ground-water levels between } \\
\cline { 2 - 4 } & $\begin{array}{c}\text { October } 1988 \text { and October } \\
1990\end{array}$ & $\begin{array}{c}\text { October } 1988 \text { and } \\
\text { April } 1994\end{array}$ & $\begin{array}{c}\text { October } 1990 \text { and } \\
\text { April } 1994\end{array}$ \\
\hline Number of wells & 28 & 29 & 75 \\
Mean difference of water levels & -.82 & -3.97 & -2.65 \\
$\begin{array}{l}\text { Standard deviation of water } \\
\text { levels }\end{array}$ & 1.60 & 3.08 & 1.45 \\
$\begin{array}{l}\text { Minimum water-level } \\
\text { difference }\end{array}$ & 3.18 & & \\
$\begin{array}{l}\text { Maximum water-level } \\
\text { difference }\end{array}$ & (at FH-13-OBS) & -.49 & -.6 \\
\hline & -7.26 & $($ at MI-19) & $($ at MI-19) \\
& (at FH-5-OBS1) & -15.23 & -7.97 \\
(at FH-5-OBS1) & (at FH-5-OBS1) \\
\hline
\end{tabular}

ground-water hydraulic gradients during periods of heavy precipitation or snowmelt such as in December 1994. At locations where the river gains ground water, surface waters recede more quickly than ground waters and, therefore, increase surface to ground water hydraulic gradients during dry periods following precipitation; this took place in October 1994 after a rainstorm in September 1994.

Variations in hydraulic gradients between surface and ground water were largest at river gage $\mathrm{FH}-27$ (fig. 4). Large gradient changes are supported by ground water hydraulic gradients in this area that show large directional movement of maximum hydraulic gradients.

Hydraulic gradients provide important insight into river-aquifer interactions and data can show patterns of aquifer recharge and discharge from and to rivers. The direction of hydraulic gradients for the MSGD study area are fairly constant throughout the year. Therefore, estimates of streamflow gains and losses from coupled discharge measurements of gaging stations are not affected by changes in the direction of ground-water flow between surface and ground waters but are possibly affected by changes in the magnitude of aquifer recharge or discharge and factors such as (1) accuracies in measurements of discharge, (2) the relative magnitude of streamflow, and (3) climatic/seasonal changes in streamflow processes (interflow and surface runoff).

Base flow composed 71 percent of total streamflow at WLR-5 from July 1994 to September 1995 based on estimates of base flow from hydrograph separation techniques (Albert Rutledge, U.S.

Geological Survey, written commun., 1994). The average rate of base flow or ground-water contribution to streamflow can be used to interpret percent of aquifer discharge from average streamflow gains reported on the Souhegan River between stations WLR-5 and station 39 (fig. 11). The average aquifer discharge between WLR-5 and station 39 is $4.8 \mathrm{ft}^{3} / \mathrm{s}$ or 71 percent of the average measured gain of $6.8 \mathrm{ft}^{3} / \mathrm{s}$. Whereas, the base-flow component of streamflow must be factored in to interpret the amount of aquifer discharge from measured streamflow gains, the base flow is not a factor in losing reaches in interpreting the amount of aquifer recharge from measured streamflow losses. In the latter, all streamflow loss contributes to aquifer recharge because flow reversals from temporary bank storage were not detected.

\section{RESULTS OF PHYSICAL WATER- PROPERTY DATA COLLECTION}

Graphs of daily mean specific conductance and water temperature from continuously measured sites are presented in this report. Instantaneous readings of 
Table 10. Difference between October 1990 synoptic ground-water levels and the arithmetic mean of ground-water levels from biweekly measurements (June 1994-June 1995), Milford, New Hampshire

[All units are in feet; altitude of water level in feet above sea level; positive value indicates 1990 water level is higher than the mean water level]

\begin{tabular}{|c|c|c|c|c|}
\hline \multirow[t]{2}{*}{$\begin{array}{c}\text { Well name } \\
\text { (plate 1) }\end{array}$} & \multirow[t]{2}{*}{$\begin{array}{c}\text { Well } \\
\text { number }\end{array}$} & \multirow[t]{2}{*}{$\begin{array}{l}\text { Altitude of ground- } \\
\text { water level from } \\
\text { October } 1990\end{array}$} & $\begin{array}{l}\text { Arithmetlc mean of ground- } \\
\text { water level from biweekly } \\
\text { measurements }\end{array}$ & $\begin{array}{l}\text { Difference in ground-water } \\
\text { level between October } 1990 \\
\text { and blweekly mean }\end{array}$ \\
\hline & & & \multicolumn{2}{|c|}{ June 1994-95 } \\
\hline MW-IB & 309 & 272.09 & 271.62 & 0.47 \\
\hline MI-7 & 21 & 250.78 & 250.77 & .01 \\
\hline MI-4 & 165 & 251.99 & 251.98 & .01 \\
\hline MW-3 & 228 & 261.04 & 261.43 & -.39 \\
\hline MI-10 & 23 & 249.12 & 248.90 & .22 \\
\hline MI-12 & 25 & 247.46 & 247.50 & -.04 \\
\hline$M W-4 A$ & 312 & 260.56 & 261.63 & -1.07 \\
\hline MW-4B & 212 & 260.69 & 261.79 & -1.10 \\
\hline FH-5obsl & 240 & 240.13 & 244.64 & -4.51 \\
\hline FH-13obsl & 86 & 249.88 & 252.65 & -2.77 \\
\hline$M W-6 A$ & 348 & 258.81 & 260.00 & -1.19 \\
\hline FH-27 & 306 & 245.90 & 247.64 & -1.74 \\
\hline MW-6B & 214 & 258.83 & 259.82 & -.99 \\
\hline MW-7A & 314 & 258.38 & 259.18 & -.79 \\
\hline MW-7B & 215 & 258.34 & 259.27 & -.93 \\
\hline MW-8A & 315 & 257.56 & 258.29 & -.73 \\
\hline MW-8B & 216 & 257.53 & 258.13 & -.60 \\
\hline MI-28 & 43 & 261.23 & 262.24 & -1.01 \\
\hline$M W-10 A$ & 316 & 256.86 & 257.72 & -.86 \\
\hline$M W-10 B$ & 317 & 256.49 & 257.34 & -.85 \\
\hline MW-10C & 218 & 257.17 & 258.01 & -.84 \\
\hline MW11A & 318 & 255.98 & 255.98 & 0 \\
\hline$M W-2 B$ & 210 & 260.06 & 260.54 & -.48 \\
\hline MW-11B & 319 & 255.88 & 255.87 & .01 \\
\hline MW-11R & 219 & 254.72 & 254.90 & -.18 \\
\hline$M W-16 A$ & 233 & 258.48 & 259.34 & -.86 \\
\hline MW-16B & 321 & 258.57 & 259.46 & -.89 \\
\hline MW-12A & 220 & 253.51 & 253.70 & -.19 \\
\hline MW-12B & 320 & 253.31 & 253.70 & -.39 \\
\hline MW-16C & 344 & 258.67 & 259.50 & -.83 \\
\hline MW-13A & 308 & 252.84 & 252.93 & -.09 \\
\hline MW-13B & 221 & 254.45 & 254.79 & -.34 \\
\hline MW-28 & 225 & 264.80 & 266.89 & -2.09 \\
\hline$M W-14 B$ & 341 & 248.78 & 249.42 & -.64 \\
\hline MW-33 & 306 & 246.54 & 247.37 & -.83 \\
\hline MW-34 & 281 & 245.53 & 245.67 & -.14 \\
\hline MW-17A & 258 & 257.72 & 258.53 & -.81 \\
\hline MW-17B & 322 & 257.76 & 258.53 & -.77 \\
\hline MW-17C & 323 & 257.69 & 258.46 & -.77 \\
\hline SPZ-1 & 285 & 252.55 & 253.35 & -.80 \\
\hline MW-19A & 326 & 255.90 & 255.94 & -.04 \\
\hline MW-19B & 327 & 255.87 & 255.99 & -.12 \\
\hline MW-20A & 264 & 254.98 & 255.13 & -.15 \\
\hline MW-20B & 328 & 254.73 & 255.11 & -.38 \\
\hline MW-22A & 293 & 243.82 & 243.53 & .29 \\
\hline MW-22B & 294 & 243.82 & 243.50 & .32 \\
\hline MW-24A & 255 & 250.56 & 250.93 & -.39 \\
\hline MW-24B & 333 & 250.62 & 250.95 & -.33 \\
\hline MW-32A & 296 & 243.60 & 242.71 & .89 \\
\hline MW-32B & 297 & 243.67 & 242.79 & .88 \\
\hline TOTAL & - & - & - & -.59 \\
\hline
\end{tabular}




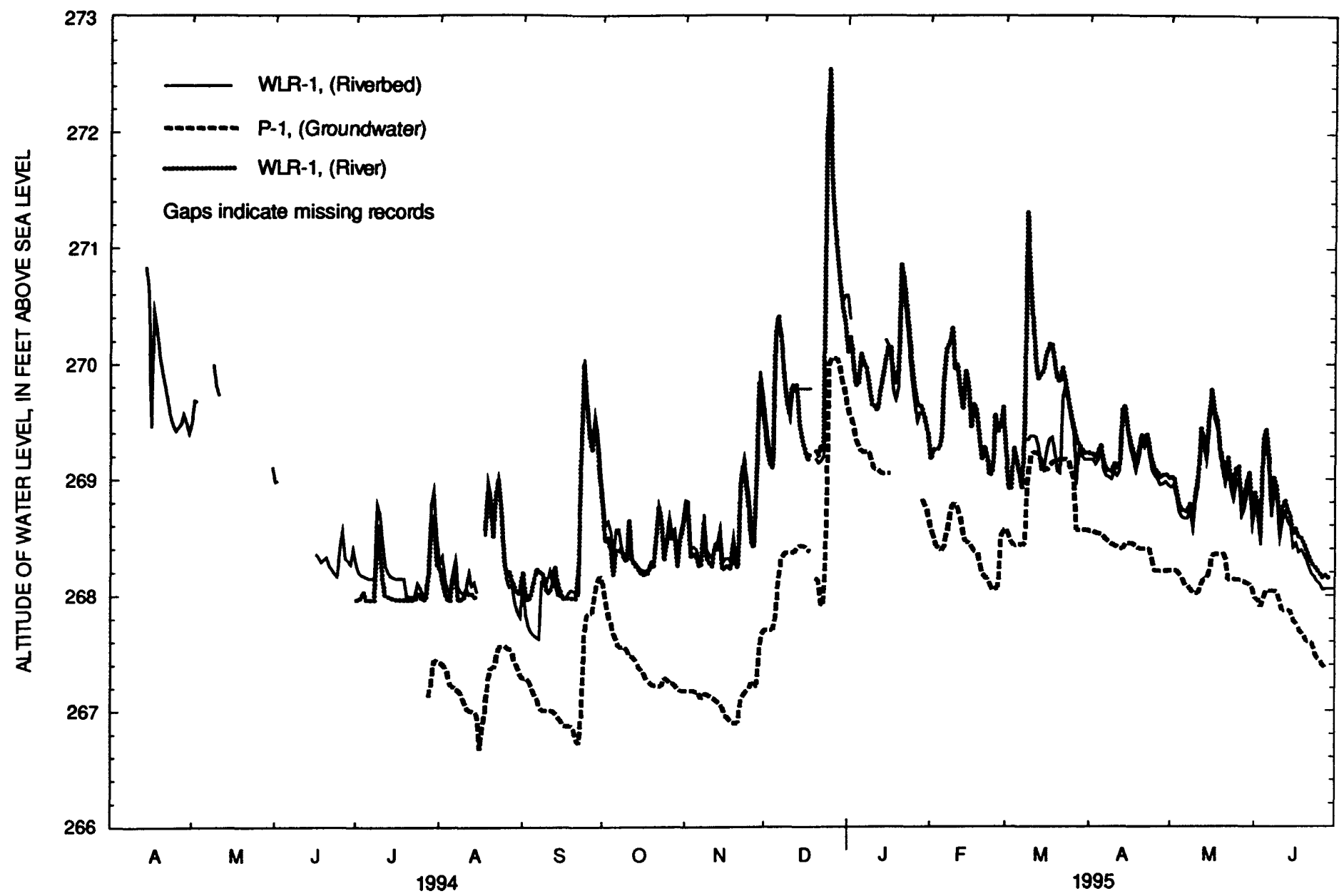

Figure 18. Continuous daily mean river stage and riverbed water levels for streamflow-gaging station WLR-1, and ground-water level for well P-1, Milford, New Hampshire.

continuous data are not reported but are available upon request.

\section{Surface Water}

Specific conductance and water temperature were measured for surface water at streamflow-gaging stations WLR-1 and WLR-5 on the Souhegan River and WLR-4 on the discharge ditch. The range in data are plotted in hydrographs and for riverbed waters in figure 20.

Specific conductances of river water range from 50 to $500 \mu \mathrm{S} / \mathrm{cm}$ on the Souhegan River and 300 to $600 \mu \mathrm{S} / \mathrm{cm}$ on the discharge ditch. Specific conductance of riverbed water was less variable; however, trends in specific conductances of riverbed water generally followed trends of river water. At WLR-5, upward and downward inflections of changes in specific conductance of riverbed water appear to lag about a day behind river water (fig. 20).
Water temperatures of the Souhegan River ranged from $0^{\circ} \mathrm{C}$ in winter to $24^{\circ} \mathrm{C}$ in summer. Temperatures of water in the discharge ditch were higher on average than water in the Souhegan River. The discharge ditch carries primarily processed waters from two industrial facilities. Riverbed water temperatures varied less than those of river waters.

Water temperatures of the discharge ditch showed greater variation in daily means than on the Souhegan River. This could be because of variations in processed waters from manufacturing discharges to the ditch.

\section{Ground Water}

Specific conductance and water temperature were measured for ground water at stations P-1, P-2, and MW-2A, in western part of the MSGD by the Souhegan River (fig. 21). Both physical properties are affected by the location and depth of well screens. 

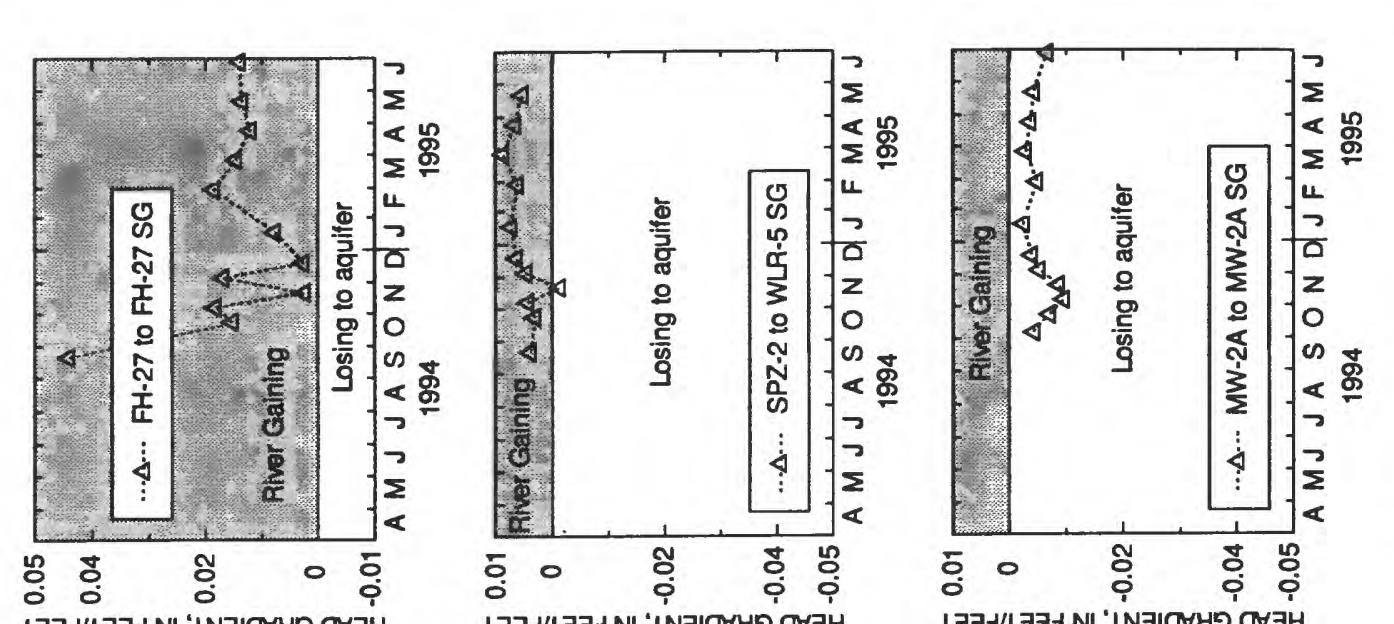

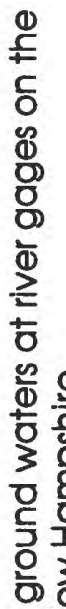

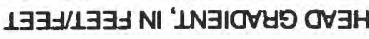

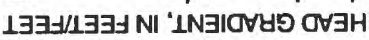

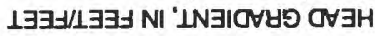
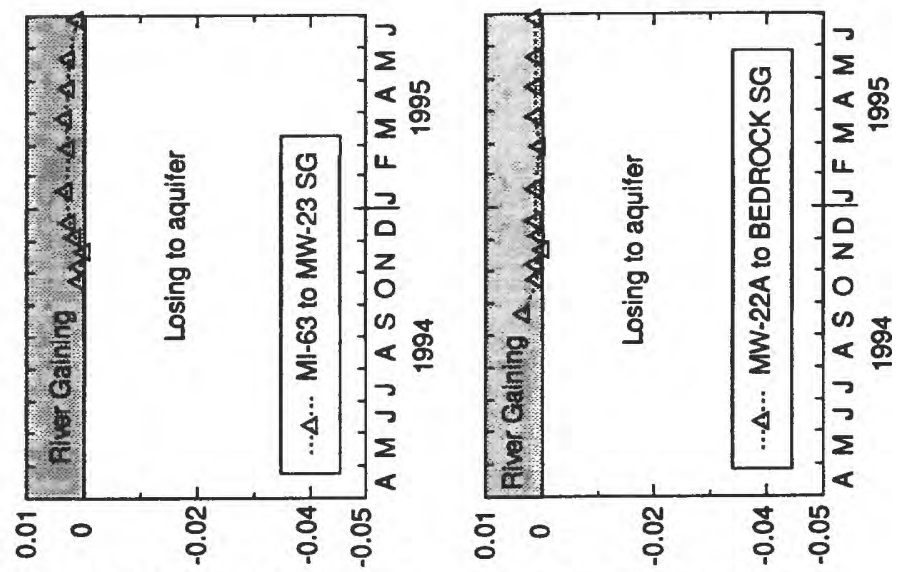

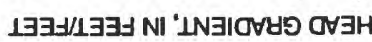

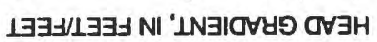

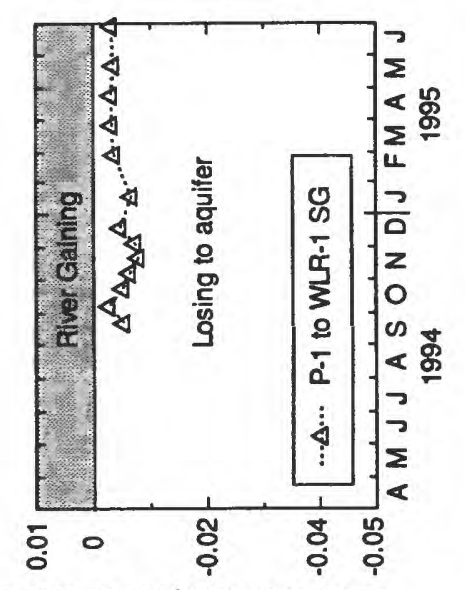

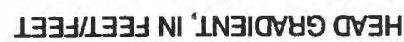

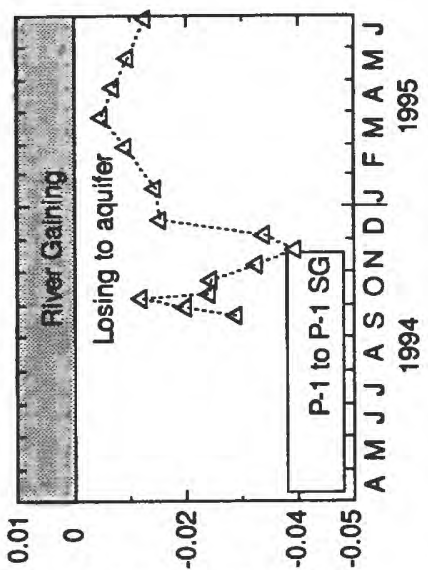

1

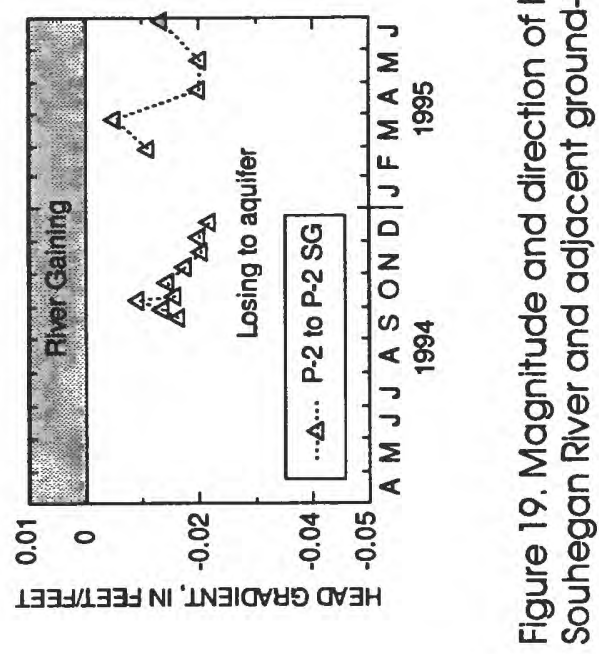



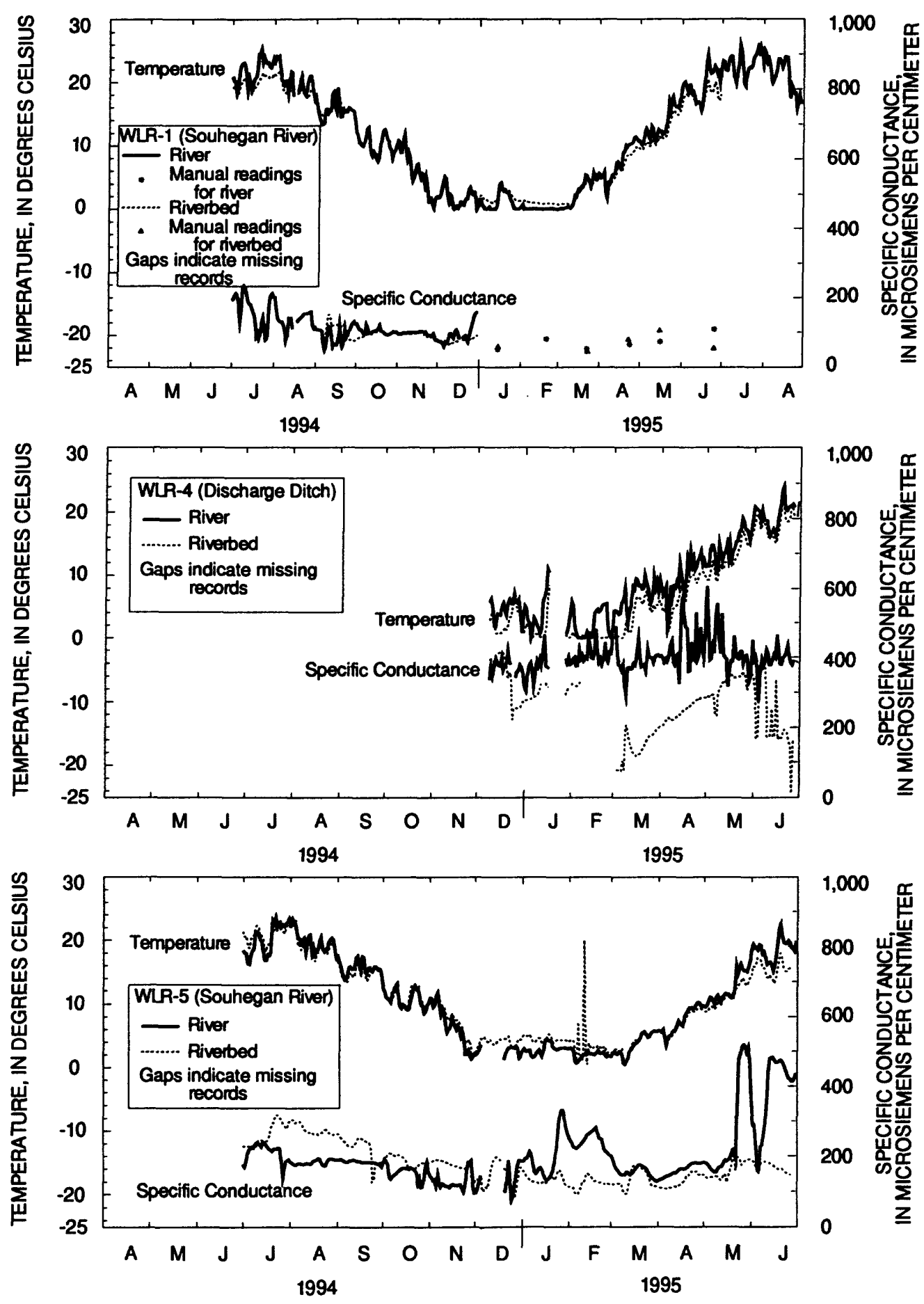

Figure 20. Daily mean speciffc conductance and temperature of waters for streamflow-gaging stations WLR-1. WLR-4, and WLR-5, Milford. New Hampshire. 
Specific conductances of ground water ranged from 75 to $200 \mu \mathrm{S} / \mathrm{cm}$ at wells P-1 (well number 335), P-2 (well number 336), and MW-2A (well number 310) (fig. 21). Specific conductance values at well P-1 showed greater variability and higher values in winter than wells P-2 and MW-2A. Well P-1 is adjacent to Route $101 \mathrm{~A}$ and is probably affected by runoff of road de-icing chemicals.

Water temperatures ranged from $8^{\circ} \mathrm{C}$ to $16^{\circ} \mathrm{C}$. Water temperatures fluctuate as the result of seasonal differences in air temperature and follow a cosine curve function. Differences in maximum and minimum temperatures at sites are the result of different probe locations and the depth of the well screen interval below land surface. At the shallowest well (P-1), the screen interval was 13.9 to $14.9 \mathrm{ft}$ below land surface, and maximum and minimum water temperatures were recorded earliest in the year, late August and April, respectively. At the middle well depth (P-2), the screen interval was 17.0 to $18.0 \mathrm{ft}$ below land surface, and maximum and minimum water temperatures were recorded about 1 month later than P-1. At the deepest well (MW-2A), the screen interval was 29.0 to $39.0 \mathrm{ft}$ below land surface, and maximum and minimum water temperatures were recorded last, about 3 months after P-1. In addition to increased lag time, the amplitude or difference between maximum and minimum temperatures decreased with depth.

\section{Surface-Water and Ground-Water Interactions}

Graphs of specific conductance and water temperatures are shown for gaging station WLR-1 on the Souhegan River with adjacent ground-water wells (fig. 21). These wells were compared to gain some understanding of the effect of surface and ground-water interactions.

By comparing the specific conductance of surface and ground water, an apparent relation emerges between surface water at gaging station WLR-1 and ground water at well P-2 but not between WLR-1 and P. 1. For example, water at both WLR-1 and P-2 show a small decline in specific conductances in March 1995 followed by a rise in specific conductances in April 1995; however, specific conductances at P-1 react independently from WLR-1 and P-2. Water at well P-1 appears to be affected by periodic road de-icing chemicals in cold months, whereas, water at WLR-1 and P-2 were apparently unaffected by road de-icing chemicals. The similarity in specific conductance of water at WLR-1 and P-2 and dissimilarity at WLR-1 and $P-1$ suggest waters from $P-2$ are recharged from the Souhegan River near WLR-1 but waters from P-1 are probably recharged further upstream given the predominant ground-water hydraulic gradients in the area, which are 30 to 45 degrees from the tangent line of the river.

A comparison of water temperatures for surface and ground water shows approximately a 6-month lag between frequency of maximum and minimum water temperatures (fig. 21). The lag time between surface and ground water is beneficial in mapping areas of ground-water discharge to the Souhegan River. In the summer, cool ground water discharges to the river and decreases the river temperatures. In the winter, the converse is true. Spot measurements of river-water temperatures along the Souhegan River on June 30, 1995, (unpublished data available upon request from the USGS) showed a drop in temperature between gaging station 22 and station 41 (fig. 4). The reach of the Souhegan River between these two stations is a transition zone between losing streamflow and gaining streamflow.

\section{SUMMARY AND CONCLUSIONS}

This report summarizes one and a half years of surface and ground-water data that was collected from. April 1994 to September 1995 during a period that represented near normal rates of precipitation and streamflow in Milford, N.H. These data were collected to understand the temporal variability of hydrologic conditions in the Milford-Souhegan glacial-drift (MSGD) aquifer. Data collected and presented in this report include river stages, riverbed water levels, streamflow, ground-water levels, and temperature and specific conductance. This report is part of a 3-year study by the U.S. Geological Survey and the U.S. Environmental Protection Agency to help understand the temporal variability of ground-water flow in the MSGD aquifer and the effect of flow on contaminant transport.

The MSGD aquifer is typical of other permeable, glacial-drift aquifers with a good hydraulic connection between surface and ground water. Data on river stages, riverbed water levels, and ground-water levels adjacent to rivers indicate that the hydrologic system acts in 

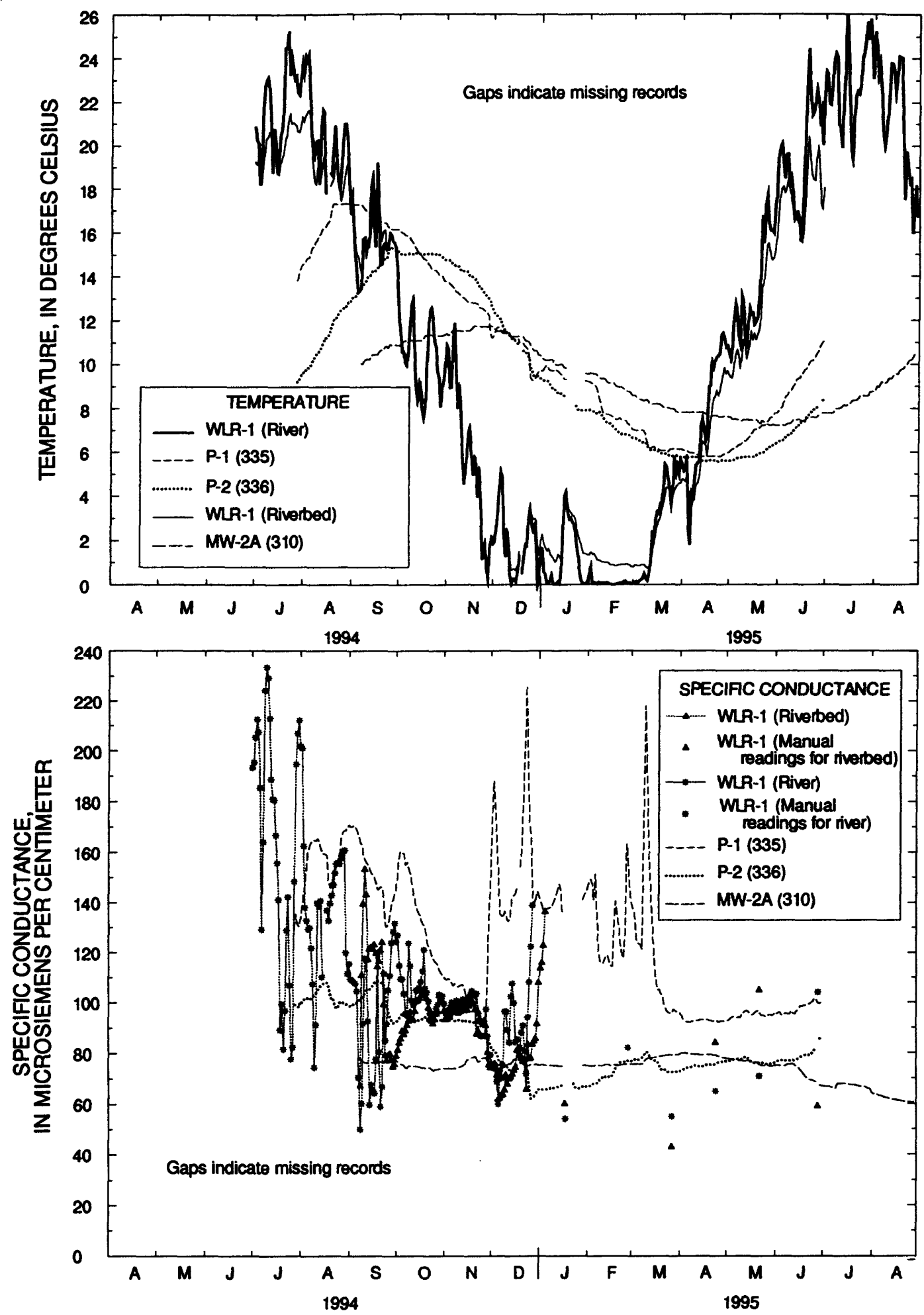

Figure 21. Daily mean specific conductance and temperature of waters for streamflow-gaging station WLR-1 and observation wells P-1, P-2, and MW-2A, Milford, New Hampshire. 
unison because of the good hydraulic connection between surface and ground water and because soil and water-table conditions allow precipitation to quickly infiltrate and recharge the water table.

River stages fluctuated nonuniformly on the Souhegan River and its tributaries. River stage fluctuated between 5 and $7 \mathrm{ft}$ on the Souhegan River. Riverbed water levels mimic river stages.

Streamflow varied from 15 to $1,500 \mathrm{ft}^{3} / \mathrm{s}$ in the Souhegan River but discharge did not exceed $100 \mathrm{ft}^{3} / \mathrm{s}$ in the tributaries. Base flow composes about 71 percent of total streamflow. Streamflow was relatively constant ranging from 0.14 to $0.8 \mathrm{ft}^{3} / \mathrm{s}$ in the industrial discharge ditch that is fed by industrial processed waters.

On the Souhegan River, streamflow gains and loses water as determined from differences in streamflow at reaches between two successive gaging stations, called reaches. The upstream reach averaged a $4.8 \mathrm{ft}^{3} / \mathrm{s}$ loss $\left(0.0045 \mathrm{ft}^{3} / \mathrm{s}\right.$ per length in stream $)$ with a maximum loss of $23 \mathrm{ft}^{3} / \mathrm{s}$. The downstream reach averaged $6.8 \mathrm{ft}^{3} / \mathrm{s}$ gain $\left(0.0063 \mathrm{ft}^{3} / \mathrm{s}\right.$ per length in stream) with a maximum gain of $21 \mathrm{ft}^{3} / \mathrm{s}$. Streamflow losses were greater in the fall and winter than in the spring and summer and gains were greater in the winter and spring. Compared to previous studies that investigated streamflow gains/losses during low-flow conditions (streamflow duration greater than 70 percent), this study showed large gains/losses when flow streamflow duration was less than 70 percent.

Ground-water levels generally fluctuated less than $5 \mathrm{ft}$ at most wells, which corresponds to the range of river-stage fluctuations found along much of the Souhegan River. Maximum fluctuations of up to $16.47 \mathrm{ft}$ were found at observation wells near the State Fish Hatchery withdrawal wells. The combined effect of seasonal patterns in withdrawals and recharge caused a large expansion and contraction of the cone of depression around the withdrawal well.

Apparent ground-water hydraulic gradients from shallow wells along transects through the plume showed a fairly constant longitudinal gradient that averaged $0.0757 \mathrm{ft} / \mathrm{ft}$ with a standard deviation of 0.0014 . Seasonal variations in apparent ground-water hydraulic gradients varied when perpendicular to the plume. Ground-water hydraulic gradients averaged 0.0176 with a standard deviation of 0.0027 , almost twice the standard deviation of the longitudinal gradient.
Computations of maximum ground-water gradients from three-point planar solutions, which differ in orientation from apparent gradients, showed the largest variability near rivers and withdrawal wells. Directional changes in maximum gradients were largest and ranged by 144 degrees near the confluence of two rivers (Souhegan River and Purgatory Brook) where the contaminant plume has migrated, abetted by the large directional change in this area. Other areas of large directional change include (1) near the upstream reach of the Souhegan River by the contaminant source area, ranged by 51 degrees, and (2) near the State Fish Hatchery withdrawal wells, ranged by 49 degrees. Remaining areas ranged from 5 to 28 degrees. The largest change in slope of maximum gradients occurred near State Fish Hatchery wells and ranged from 0.202 to $0.723 \mathrm{ft} / \mathrm{ft}$. Other areas of large change in slope of maximum gradients include same areas where large directional changes resulted in maximum gradients. Near the source area of the plume, gradients ranged from 0.313 to $0.567 \mathrm{ft} / \mathrm{ft}$. Near the confluence of the Souhegan River and Purgatory Brook, gradients ranged from 0.113 to $0.423 \mathrm{ft} / \mathrm{ft}$. Most other areas had less than a 40-percent change in maximum gradients.

Transient variations in ground-water gradients are also evident when comparing water-table maps from two low-flow and one high-flow synoptic. During a high precipitation and high ground-water recharge in April 1994 (high-flow synoptic), water-table contours shifted northward on the southern flank of the plume compared to low recharge periods. This indicates a partial shifting of flow from a easterly direction during low precipitation and low ground-water recharge periods to a more northward direction during high recharge periods. Some northward shifting must be caused by long-term variations in ground-water withdrawals in the aquifer. These withdrawals have decreased at the two industrial wells, from $0.83 \mathrm{ft}^{3} / \mathrm{s}$ in October 1988 to $0.38 \mathrm{ft}^{3} / \mathrm{s}$ in April 1994. Withdrawals have increased at the commercial state fish hatcheries, from $3.41 \mathrm{ft}^{3} / \mathrm{s}$ in October 1988 to $4.06 \mathrm{ft}^{3} / \mathrm{s}$ in April 1994.

Hydraulic gradients between river stages and adjacent shallow ground-water levels were consistent in maintaining either positive (potential streamflow loss) or negative (potential streamflow gain) gradients. This indicates that direction of flow between surface and ground waters is consistent throughout the year. Gradients varied by one order of magnitude from 0.004 
to $0.04 \mathrm{ft} / \mathrm{ft}$. The relative quickness of response of the aquifer and river to climatic events dictated the occurrence of maximum and minimum gradients. At locations where the river lost water to the aquifer, maximum gradients occurred during rising river stages because the river reacts more quickly to climatic events like precipitation or snowmelt than do ground-water levels in the aquifer. At locations where the river gained water, maximum gradients occurred during declining river stages again because the river reacts more quickly to the absence of precipitation or snowmelt.

Physical data collected at three surface-water stations and three ground-water wells show that specific conductance was highest on the discharge ditch ranging from 300 to $600 \mu \mathrm{S} / \mathrm{cm}$ and the least in ground-water wells ranging from 75 to $200 \mu \mathrm{S} / \mathrm{cm}$. Specific conductances were highest in winter and spring and lowest in the fall. Water temperatures varied from 0 to $24^{\circ} \mathrm{C}$ at the three surface-water sites and 8 to $16^{\circ} \mathrm{C}$ at the three ground-water wells. Water temperature showed a lag time associated with heating and cooling of waters from surface to ground water at depth probably from thermal conduction.

The data collected on transient hydrologic conditions in Milford was used to describe the dynamics of ground-water flow in glacial-drift rivervalley aquifers. Understanding surface and groundwater interactions is important in evaluating groundwater recharge and discharge patterns at Milford and other similar sites. In this study, directions of hydraulic gradients did not change at seven coupled surface and ground-water measurement sites; however, near a confluence between two rivers, fluctuations in river stage between the two rivers produced variations in ground-water discharge patterns. Variations in groundwater hydraulic gradients from seasonal recharge and river-stage fluctuations may explain the distribution of volatile organic contaminants found in the aquifer. Additional data collection, in conjunction with a single measurement of ground-water levels, allows for a more thorough understanding of the effect of physical-flow processes on contaminant distribution. Lastly, groundwater flow is most variable near ground-water recharge and discharge boundaries, such as rivers and withdrawal wells and, therefore, it is important to collect transient data in those areas.

\section{SELECTED REFERENCES}

Coakley, M.F., Keirstead, Chandlee, Brown, R.O., and Hilgendorf, G.S., 1997, Water resources data New Hampshire and Vermont water year 1996:U.S. Geological Survey Water-Data Report NH-VT-96-1, 189 p.

Hammond, R.E., Coakley, M.F., Keirstead, Chandlee, and Kiah, R.G., 1995, Water resources data New Hampshire and Vermont water year 1994: U.S. Geological Survey Water-Data Report NH-VT-95-1, 205 p.

Harte, P.T., and Mack, T.J., 1992, Geohydrology of, and simulation of ground-water flow in the Milford-Souhegan glacial-drift aquifer, Milford, New Hampshire: U.S. Geological Survey Water-Resources Investigations Report 91-4177, 90 p.

HMM Associates, Inc., 1989, Draft remedial investigation, Savage well site, Milford, New Hampshire: Concord, Mass., no. $2176 \mathrm{HAZ} / 2880,218 \mathrm{p}$.

1991, Remedial investigation, Savage well site, Milford, New Hampshire: Concord, Mass., no. 2176 $\mathrm{HAZ} / 4814,800 \mathrm{p}$.

Koteff, Carl, 1970, Surficial geologic map of the Milford quadrangle, Hillsborough County, New Hampshire: U.S. Geological Survey Geologic Quadrangle Map GQ881 , scale 1:62,500.

Marschak, Stephen, and Mitra, Gautain, 1988, Basic methods in structural geology: Prentice-Hall, Englewood Cliffs, N.J., p. 47-49.

New Hampshire Department of Environmental Services, 1985, Hydrogeological investigation of the Savage well site, Milford, New Hampshire: New Hampshire Water Supply and Pollution Control Division, Report 145, $91 \mathrm{p}$.

Olimpio, J.R., and Harte, P.T., 1994, Reassessment of geohydrologic data and refinement of a regional ground-water flow-model of the Milford-Souhegan glacial-drift aquifer, Milford, New Hampshire: U.S. Geological Survey Water-Resources Investigations Report 95-281, 40 p.

Rantz, S.E., 1982a, Measurement and computation of streamflow--Methods of measurement: U.S. Geological Survey Water-Supply Paper 2175, v. 1, p. 1-284.

$1982 \mathrm{~b}$, Measurement and computation of streamflow-Computation of discharge: U.S. Geological Survey Water-Supply Paper 2175, v. 2, p. 285-631. 
Rutledge, A.T., 1993, Computer programs for describing the recession of ground-water discharge and for estimating mean ground-water recharge and discharge from streamflow records: U.S. Geological Survey WaterResources Investigations Report 93-412, 45. p.

Stevens, H.H., Ficke, J.F., and Smoot, G.F., 1975, Water temperature--Influential factors, field measurement, and data presentation: U.S. Geological Survey Techniques of Water-Resources Investigations, chap. D1, book 1, p. 1-65.

Toth, J. 1962, A theory of groundwater motion in small drainage basins in Central Alberta, Canada: Journal of Geophysical Research, v. 67, no. 11, p. 4375-4387.

Toppin, K.W., Coakley, M.F., Keirstead, Chandlee, and Flanagan, S.M., 1994, water resources data New Hampshire and Vermont water year 1994: U.S. Geological Survey Water-Data Report NH-VT-91-1, 210 p.

Wilcoxon, F., 1945, Individual comparisons by ranking methods: Biometrics, 1, p. 80-83. 
APPENDIX 1 
Appendix 1. Information on well construction for selected wells in Milford, New Hampshire [altitude in feet above sea level; depth in feet below land surface; - , no data]

\begin{tabular}{|c|c|c|c|c|c|c|c|c|}
\hline \multirow{2}{*}{$\begin{array}{c}\text { well } \\
\text { number } \\
\text { on plate }\end{array}$} & \multirow[t]{2}{*}{ Well name } & \multicolumn{2}{|c|}{ Altitude of } & \multicolumn{5}{|c|}{ Depth } \\
\hline & & $\begin{array}{l}\text { measurement } \\
\text { point }\end{array}$ & $\begin{array}{c}\text { land } \\
\text { surface }\end{array}$ & of well & $\begin{array}{l}\text { to top of } \\
\text { screen }\end{array}$ & $\begin{array}{l}\text { to bottom } \\
\text { of screen }\end{array}$ & $\begin{array}{c}\text { to } \\
\text { refusal }\end{array}$ & $\begin{array}{c}\text { to } \\
\text { bedrock }\end{array}$ \\
\hline 1 & KEYES - 1 & 250.71 & 248.7 & 55.0 & 53.0 & 55.0 & - & 85.00 \\
\hline 2 & KEYES - 2D & 248.61 & 246.6 & 56.5 & 54.5 & 56.5 & - & -- \\
\hline 3 & KEYES - 3D & 246.84 & 244.8 & 50.7 & 48.7 & 50.7 & -- & $\cdots$ \\
\hline 4 & KEYES - 4D & 245.28 & 243.3 & 51.9 & 49.9 & 51.9 & $\cdots$ & $\cdots$ \\
\hline 5 & $L W-01 D$ & - & 264.8 & 110.0 & 100.0 & 110.0 & $\cdots$ & 114.30 \\
\hline 6 & $L W-02 D$ & 245.66 & 243.1 & 55.0 & 45.0 & 55.0 & -- & 62.50 \\
\hline 7 & $L W-03 D$ & 251.14 & 247.3 & 54.5 & 44.5 & 54.5 & $\cdots$ & 80.20 \\
\hline 8 & $L W-04 D$ & 246.43 & 243.4 & 50.0 & 40.0 & 50.0 & $\cdots$ & 80.00 \\
\hline 9 & MOW-33 & -- & 260.0 & 70.0 & 60.0 & 70.0 & -- & 56.00 \\
\hline 10 & GW-02D & -- & 255.4 & 29.0 & 19.0 & 29.0 & -- & 34.00 \\
\hline 11 & GW- 03D & -- & 252.4 & 38.0 & 28.0 & 38.0 & $\cdots$ & 23.50 \\
\hline 12 & GW-04D & -- & 255.6 & 31.5 & 21.5 & 31.5 & -- & 19.00 \\
\hline 13 & GW- 05D & $\cdots$ & 261.0 & 33.0 & 23.0 & 33.0 & $\cdots$ & 33.00 \\
\hline 14 & RFW-1 & - & 255.7 & 28.0 & 8.0 & 28.0 & 28.00 & - \\
\hline 15 & RFW - 2 & 253.87 & 253.8 & 35.0 & 10.0 & 35.0 & 35.00 & -- \\
\hline 16 & RFW-3 & 253.51 & 253.5 & 43.0 & 13.0 & 43.0 & 43.00 & -- \\
\hline 17 & RFW - 4 & 252.15 & 251.6 & 16.0 & 6.0 & 16.0 & 16.00 & $\cdots$ \\
\hline 18 & PA-1 & - & 255.1 & 8.7 & - & 8.7 & -- & -- \\
\hline 19 & $P A-2$ & $\cdots$ & 254.9 & 8.7 & $\cdots$ & 8.7 & $\cdots$ & $\cdots$ \\
\hline 20 & $P A-3$ & $\cdots$ & 255.3 & 7.8 & - & 7.8 & - & -- \\
\hline 21 & MI - 7 & 256.68 & 253.2 & 37.8 & -- & 31.0 & -- & - \\
\hline 22 & MI - 8 & 265.95 & 262.6 & - & - & - - & - & - - \\
\hline 23 & MI - 10 & 255.12 & 252.2 & 45.8 & 44.0 & 47.0 & - & 58.50 \\
\hline 24 & MI-11 & 254.52 & 252.1 & 55.5 & 40.0 & 56.0 & 63.00 & - \\
\hline 25 & $M I-12$ & 253.26 & 251.5 & 38.1 & 43.0 & 49.0 & 50.00 & -- \\
\hline 26 & MI - 15 & 265.17 & 264.7 & - & - & - & - & $\cdots$ \\
\hline 27 & $M I-16$ & $\cdots$ & 269.1 & $\cdots$ & $-\cdot$ & - & - & - \\
\hline 29 & $M I-18$ & 264.42 & 262.4 & -- & - & 11.0 & $\cdots$ & - \\
\hline 30 & MI-19 (Bedrock) & 277.50 & 275.6 & 80.0 & 65.0 & 80.0 & $\cdots$ & 63.50 \\
\hline 31 & $M I-20$ & 277.47 & 275.6 & 40.0 & 10.0 & 40.0 & $\cdots$ & 63.50 \\
\hline 32 & $M I-20 A$ & - & 274.7 & 14.8 & -- & 14.8 & $-\cdot$ & -- \\
\hline 33 & $M I-21$ & -- & 273.0 & 40.0 & 15.0 & 40.0 & $\cdots$ & 53.00 \\
\hline 34 & $M I-21 A$ & - - & 270.0 & $-\cdot$ & - & $\cdots$ & - & - \\
\hline 35 & $M I-22$ & 272.34 & 270.0 & 114.0 & 99.0 & 114.0 & -- & 94.00 \\
\hline 36 & $M I-22 A$ & - & 270.1 & 11.7 & - - & 11.7 & $-\cdot$ & - - \\
\hline 37 & $M I-23$ & - & 270.0 & 75.0 & 10.0 & 75.0 & $\cdots$ & 94.00 \\
\hline 38 & $M I-24$ & 273.41 & 270.7 & 85.0 & 10.0 & 85.0 & -- & 96.00 \\
\hline 39 & $M I-24 A$ & $\cdots$ & 272.0 & 14.0 & - & 14.0 & - & - \\
\hline 40 & MI - 25 & 272.35 & 270.1 & 111.0 & 101.8 & 111.0 & $\cdots$ & 105.00 \\
\hline 41 & $M I-26$ & 272.35 & 270.1 & 88.0 & 8.0 & 88.0 & -- & 105.00 \\
\hline 42 & $M I-27$ & 273.43 & 270.7 & 78.0 & 13.0 & 78.0 & - & 88.00 \\
\hline 43 & $M I-28$ & 271.85 & 270.3 & 55.0 & 35.0 & 55.0 & 56.00 & $\cdots$ \\
\hline 44 & MI - 30 & 269.35 & 265.7 & 72.0 & 27.0 & 72.0 & 75.00 & -- \\
\hline 45 & MI - 31 & 267.23 & 266.1 & 54.0 & 36.0 & 54.0 & - & - \\
\hline 46 & MI - 32 & 273.36 & 270.2 & 75.0 & 30.0 & 75.0 & - & 95.00 \\
\hline 47 & MI - 33 & 265.90 & 268.2 & 60.0 & 50.0 & 60.0 & 60.00 & - \\
\hline 49 & $M I-35$ & 263.20 & 262.2 & 55.0 & - & 55.0 & - & - \\
\hline 50 & MI - 36 & 270.51 & 269.9 & 12.7 & $\cdots$ & 12.5 & $\cdots$ & -- \\
\hline
\end{tabular}


Appendix 1. Information on well construction for selected wells in Milford, New Hampshire--Continued [altitude in feet above sea level; depth in feet below land surface; -., no data]

\begin{tabular}{|c|c|c|c|c|c|c|c|c|}
\hline \multirow{2}{*}{$\begin{array}{c}\text { Well } \\
\text { number } \\
\text { on plate }\end{array}$} & \multirow[t]{2}{*}{ Well name } & \multicolumn{2}{|c|}{ Altitude of } & \multicolumn{5}{|c|}{ Depth } \\
\hline & & $\begin{array}{l}\text { measurement } \\
\text { point }\end{array}$ & $\begin{array}{c}\text { Iand } \\
\text { surface }\end{array}$ & of well & $\begin{array}{l}\text { to top of } \\
\text { screen }\end{array}$ & $\begin{array}{l}\text { to bottom } \\
\text { of screen }\end{array}$ & $\begin{array}{c}\text { to } \\
\text { refusal }\end{array}$ & $\begin{array}{c}\text { to } \\
\text { bedrock }\end{array}$ \\
\hline 51 & MI - 37 & 272.60 & 270.4 & 12.8 & $\cdots$ & 12.5 & $\cdots$ & $\cdots$ \\
\hline 52 & MI - 38 & $\cdots$ & 270.0 & 11.9 & $\cdots$ & - & $\cdots$ & $\cdots$ \\
\hline 54 & $M I-41$ & 260.12 & 258.7 & 20.0 & $\cdots$ & 20.0 & $\cdots$ & $\cdots$ \\
\hline 55 & $M I-42$ & 258.51 & 257.2 & 20.0 & - & 20.0 & $\cdots$ & -- \\
\hline 56 & $M I-43$ & 258.82 & 257.3 & 20.0 & - & 20.0 & $\cdots$ & $\cdots$ \\
\hline 57 & MOW- 63 & $\cdots$ & 270.0 & 62.0 & 53.0 & 62.0 & 65.00 & $\cdots$ \\
\hline 58 & $M I-44$ & 260.60 & 259.2 & 20.0 & - & 20.0 & - & $-\cdot$ \\
\hline 59 & MI - 45 & - & 264.9 & $\cdots$ & $\cdots$ & - & - & $\cdots$ \\
\hline 60 & MI - 46 & -- & 267.3 & -- & $\cdots$ & $\cdots$ & $\cdots$ & $\cdots$ \\
\hline 61 & MI - 47 & $\cdots$ & 270.0 & $\cdots$ & $\cdots$ & $\cdots$ & $\cdots$ & $\cdots$ \\
\hline 62 & MI - 48 & $\cdots$ & 264.1 & $\cdots$ & - & -- & -- & $\cdots$ \\
\hline 63 & - & $\cdots$ & 282.4 & -- & $\cdots$ & -- & -- & $\cdots$ \\
\hline 64 & - & - & 265.3 & $\cdots$ & -- & $\cdots$ & $\cdots$ & $\cdots$ \\
\hline 65 & $P-03$ & 263.27 & 261.3 & -- & $\cdots$ & $\cdots$ & -- & -- \\
\hline 66 & - & - & 270.0 & $\cdots$ & $\cdots$ & $\cdots$ & $\cdots$ & $\cdots$ \\
\hline 67 & -- & -- & 250.0 & -- & -- & $\cdots$ & -- & $\cdots$ \\
\hline 68 & - & $\cdots$ & 267.9 & -- & $\cdots$ & $\cdots$ & -- & $\cdots$ \\
\hline 69 & $\cdots$ & -- & 266.3 & -- & -- & -- & -- & $\cdots$ \\
\hline 70 & $\cdots$ & $\cdots$ & 264.1 & -- & $\cdots$ & -- & $\cdots$ & $\cdots$ \\
\hline 71 & $\cdots$ & $\cdots$ & 264.0 & $\cdots$ & $\cdots$ & $\cdots$ & -- & - \\
\hline 72 & MI - 62 & $\cdots$ & 260.0 & 58.0 & 17.0 & 58.0 & -- & 60.70 \\
\hline 73 & MI - 64 & $\cdots$ & 259.9 & - & $\cdots$ & - & - & - \\
\hline 74 & MOW-35 & $\cdots$ & 260.0 & $\cdots$ & -- & -- & 59.00 & $\cdots$ \\
\hline 75 & MOA - 1 & $\cdots$ & 239.5 & $\cdots$ & $\cdots$ & $\cdots$ & 74.00 & $\cdots$ \\
\hline 76 & MOA- 2 & $\cdots$ & 244.6 & -- & $\cdots$ & $\cdots$ & - & $\cdots$ \\
\hline 77 & MOA- 3 & $\cdots$ & 241.1 & - & - & - & 52.00 & $\cdots$ \\
\hline 78 & MOA - 4 & $\cdots$ & 249.5 & 38.0 & 33.0 & 38.0 & 54.00 & $\cdots$ \\
\hline 79 & $\cdots$ & $\cdots$ & 350.0 & - & $\cdots$ & - & - - & $\cdots$ \\
\hline 80 & $\cdots$ & $\cdots$ & $\cdots$ & $\cdots$ & $\cdots$ & $\cdots$ & $\cdots$ & - \\
\hline 81 & $\cdots$ & $-\cdot$ & 239.2 & - & $\cdots$ & $\cdots$ & $\cdots$ & 26.00 \\
\hline 82 & $\cdots$ & - & 240.0 & $\cdots$ & $\cdots$ & $\cdots$ & $\cdots$ & 23.00 \\
\hline 83 & - & $\cdots$ & 240.9 & -- & $\cdots$ & $\cdots$ & $\cdots$ & - \\
\hline 84 & \#226insurv & 262.51 & 261.7 & 66.0 & 51.0 & 66.0 & $\cdots$ & 60.00 \\
\hline 85 & FH - 15 & 265.72 & 265.1 & 38.0 & 18.0 & 38.0 & $\cdots$ & $\cdots$ \\
\hline 86 & FH -13 & 269.03 & 260.0 & 43.0 & 33.0 & 43.0 & $\cdots$ & $\cdots$ \\
\hline 87 & FH - 14 & 263.53 & 262.2 & 42.0 & 32.0 & 42.0 & $\cdots$ & $\cdots$ \\
\hline 88 & FH - 16 & 262.99 & 261.0 & 26.0 & $\cdots$ & $\cdots$ & $\cdots$ & $\cdots$ \\
\hline 89 & FH -27 & 251.45 & 251.3 & 41.0 & 36.0 & 41.0 & -- & $\cdots$ \\
\hline 90 & FH - 22 & 252.64 & 253.1 & 29.0 & 24.0 & 29.0 & $-\cdot$ & $\cdots$ \\
\hline 91 & $F H-24$ & 253.27 & 251.6 & 29.0 & 24.0 & 29.0 & $\cdots$ & $\cdots$ \\
\hline 92 & $F H-25$ & 251.63 & 252.1 & 28.0 & 23.0 & 28.0 & $\cdots$ & $\cdots$ \\
\hline 93 & FH - 23 & 253.70 & 252.0 & 25.0 & 22.0 & 25.0 & $\cdots$ & $\cdots$ \\
\hline 94 & $F H-21$ & 251.63 & 252.1 & 26.0 & 21.0 & 26.0 & $\cdots$ & $\cdots$ \\
\hline 95 & FH85-8A & - & 260.0 & 26.0 & 20.0 & 26.0 & $\cdots$ & $\cdots$ \\
\hline 96 & FH1974 & $\cdots$ & 254.5 & - & -- & $\cdots$ & $\cdots$ & $\cdots$ \\
\hline 97 & B1 & $\cdots$ & 269.9 & 43.0 & $\cdots$ & $\cdots$ & 43.0 & $\cdots$ \\
\hline 98 & B3 & $\cdots$ & 269.3 & 33.8 & $\cdots$ & $\cdots$ & 33.8 & $\cdots$ \\
\hline 99 & B4 & $\cdots$ & 270.0 & 54.5 & $\cdots$ & $\cdots$ & 54.5 & $\cdots$ \\
\hline
\end{tabular}


Appendix 1. Information on well construction for selected wells in Milford, New Hampshire--Continued [altitude in feet above sea level; depth in feet below land surface; -., no data]

\begin{tabular}{|c|c|c|c|c|c|c|c|c|}
\hline \multirow{2}{*}{$\begin{array}{c}\text { Well } \\
\text { number } \\
\text { on plate }\end{array}$} & \multirow[t]{2}{*}{ Well name } & \multicolumn{2}{|c|}{ Altitude of } & \multicolumn{5}{|c|}{ Depth } \\
\hline & & $\begin{array}{l}\text { measurement } \\
\text { point }\end{array}$ & $\begin{array}{c}\text { 1and } \\
\text { surface }\end{array}$ & of well & $\begin{array}{l}\text { to top of } t \\
\text { screen o }\end{array}$ & $\begin{array}{l}\text { to bottom } \\
\text { of screen }\end{array}$ & $\begin{array}{c}\text { to } \\
\text { refusal }\end{array}$ & $\begin{array}{c}\text { to } \\
\text { bedrock }\end{array}$ \\
\hline 100 & B6 & $\cdots$ & 269.0 & 26.2 & $\cdots$ & $\cdots$ & -- & 26.20 \\
\hline 101 & B8 & $\cdots$ & 269.7 & 26.0 & - & - & $\cdots$ & $\ldots$ \\
\hline 102 & B9 & $\cdots$ & 275.3 & 40.3 & - & - & $\cdots$ & - \\
\hline 103 & B11 & $\cdots$ & 275.0 & 38.0 & -- & $\cdots$ & $\cdots$ & -- \\
\hline 104 & B12 & $\cdots$ & 275.4 & 48.4 & - & - & - & - \\
\hline 105 & - & $\cdots$ & - & $\cdots$ & $\cdots$ & $-\cdot$ & $-\cdot$ & $\cdots$ \\
\hline 106 & $\cdots$ & $\cdots$ & - & $\cdots$ & - & - & - & $\cdots$ \\
\hline 107 & - & $\cdots$ & 349.2 & $\cdots$ & -- & $-\cdot$ & $-\cdot$ & -- \\
\hline 108 & -- & $\cdots$ & - & -- & -- & -- & -- & $\cdots$ \\
\hline 109 & - & $\cdots$ & 349.3 & $\cdots$ & $\cdots$ & $\cdots$ & -- & $\cdots$ \\
\hline 110 & $\cdots$ & $\cdots$ & - - & -- & $\cdots$ & $\cdots$ & - & $\cdots$ \\
\hline 111 & $\cdots$ & $\cdots$ & - & -- & -- & - & -- & $\cdots$ \\
\hline 113 & $\cdots$ & $\cdots$ & - & - & $\cdots$ & $-\cdot$ & $\cdots$ & -- \\
\hline 115 & -- & $\cdots$ & 295.9 & -- & -- & -- & $\cdots$ & $\cdots$ \\
\hline 117 & $\cdots$ & - & - & -- & $\cdots$ & $\cdots$ & $\cdots$ & $\cdots$ \\
\hline 118 & -- & - & $\cdots$ & $\cdots$ & $\cdots$ & $\cdots$ & -- & $\cdots$ \\
\hline 119 & $\cdots$ & $\cdots$ & -- & - & $\cdots$ & - & $\cdots$ & - \\
\hline 120 & $\cdots$ & $\cdots$ & -- & - & - & $\cdots$ & $\cdots$ & - \\
\hline 121 & $\cdots$ & $\cdots$ & - & - & $\cdots$ & - & - & -- \\
\hline 122 & $W W-125$ & $\cdots$ & 269.0 & - & $\cdots$ & $\cdots$ & $\cdots$ & $\cdots$ \\
\hline 123 & GW-01s & $\cdots$ & 256.1 & 26.0 & 6.0 & 16.0 & $\cdots$ & - \\
\hline 124 & GW-01D & $\cdots$ & 256.5 & 76.4 & 60.0 & 70.0 & -- & 56.00 \\
\hline 125 & GW- 01M & $\cdots$ & 256.7 & 41.0 & 30.0 & 40.0 & $\cdots$ & - \\
\hline 126 & KEYES & $\cdots$ & 240.1 & 60.0 & 50.0 & 60.0 & $\cdots$ & $\cdots$ \\
\hline 127 & HAYWOOD & $\cdots$ & 256.3 & $\cdots$ & - & - & $\cdots$ & $\cdots$ \\
\hline 128 & Savage Well & $\cdots$ & 261.0 & 45.0 & 35.0 & 45.0 & -- & $\cdots$ \\
\hline 129 & KEYES 1 & $\cdots$ & 241.7 & 50.0 & 41.0 & 50.0 & $\cdots$ & 50.00 \\
\hline 130 & KEYES 2 & $\cdots$ & 240.5 & 60.0 & 52.0 & 60.0 & $\cdots$ & 65.00 \\
\hline 131 & KEYES 3 & $\cdots$ & 240.3 & 50.0 & 42.0 & 50.0 & $\cdots$ & 52.00 \\
\hline 132 & POTTER 1D & 253.75 & 251.8 & 57.0 & 55.0 & 57.0 & 80.00 & - \\
\hline 133 & POTTER 2D & 255.77 & 253.8 & 58.0 & 56.0 & 58.0 & $\cdots$ & -- \\
\hline 134 & POTTER 3D & 255.67 & 253.7 & 58.0 & 56.0 & 58.0 & - & $\cdots$ \\
\hline 135 & FORD 34 & - & 241.4 & 50.0 & 40.0 & 50.0 & 50.00 & - \\
\hline 136 & FORDobs 3 & 249.06 & 247.1 & 46.0 & 46.0 & 46.0 & - & 46.00 \\
\hline 137 & FORD 33 & - & 240.0 & 40.0 & 40.0 & 40.0 & -- & 42.00 \\
\hline 138 & FORD 32 & $\cdots$ & 240.0 & 42.0 & 32.0 & 42.0 & - & 42.00 \\
\hline 139 & FORD 1 & $\cdots$ & 239.8 & 50.0 & 35.0 & 50.0 & -- & 50.00 \\
\hline 140 & FORD 5 & $\cdots$ & 241.7 & 35.0 & 35.0 & 35.0 & $\cdots$ & 35.00 \\
\hline 141 & FORD 4 & - & 245.3 & 45.0 & 45.0 & 45.0 & $\cdots$ & 47.00 \\
\hline 142 & KEYES $2 S$ & 248.45 & 246.1 & 20.0 & 18.0 & 20.0 & -- & - \\
\hline 143 & KEYES 35 & 247.67 & 246.0 & 18.6 & 16.6 & 18.6 & $\cdots$ & - \\
\hline 144 & KEYES $4 S$ & 245.28 & 244.3 & 16.4 & 14.4 & 16.4 & - & 53.00 \\
\hline 145 & POTTER 1S & 253.76 & 252.0 & 17.0 & 16.0 & 17.0 & 80.00 & - - \\
\hline 146 & POTTER 2S & 255.79 & 253.7 & 20.0 & 18.0 & 20.0 & $\cdots$ & $\cdots$ \\
\hline 147 & POTTER 35 & 255.66 & 253.7 & 19.0 & 17.0 & 19.0 & - & - \\
\hline 148 & $L W-01 M$ & $\cdots$ & 265.1 & 52.6 & 42.6 & 52.6 & - & $-\cdot$ \\
\hline 149 & $L W-01 S$ & $\cdots$ & 265.2 & 35.6 & 25.6 & 35.6 & $\cdots$ & $\cdots$ \\
\hline
\end{tabular}


Appendix 1. Information on well construction for selected wells in Milford, New Hampshire--Continued [altitude in feet above sea level; depth in feet below land surface; -., no data]

\begin{tabular}{|c|c|c|c|c|c|c|c|c|}
\hline \multirow{2}{*}{$\begin{array}{c}\text { Well } \\
\text { number } \\
\text { on plate }\end{array}$} & \multirow[t]{2}{*}{ Well name } & \multicolumn{2}{|c|}{ Altitude of } & \multicolumn{5}{|c|}{ Depth } \\
\hline & & $\begin{array}{l}\text { measurement } \\
\text { point }\end{array}$ & $\begin{array}{l}\text { Iand } \\
\text { surface }\end{array}$ & of well & $\begin{array}{l}\text { to top of } \\
\text { screen }\end{array}$ & $\begin{array}{l}\text { to bottom } \\
\text { of screen }\end{array}$ & $\begin{array}{c}\text { to } \\
\text { refusal }\end{array}$ & $\begin{array}{c}\text { to } \\
\text { bedrock }\end{array}$ \\
\hline 150 & $L W-02 S$ & 245.91 & 243.4 & 14.0 & 4.0 & 14.0 & -- & $\cdots$ \\
\hline 151 & $L W-03 S$ & 250.44 & 250.0 & 19.0 & 9.0 & 19.0 & $\cdots$ & $\cdots$ \\
\hline 152 & $L W-04 S$ & 246.46 & 244.8 & 15.0 & 5.0 & 15.0 & - & -- \\
\hline 153 & MOW- 38 & $\cdots$ & 262.7 & 40.0 & 30.0 & 40.0 & 41.00 & $\cdots$ \\
\hline 154 & MOW-32 & $\cdots$ & 261.8 & 16.0 & 6.0 & 16.0 & 20.00 & $\cdots$ \\
\hline 155 & $\mathrm{GW}-02 \mathrm{~S}$ & $\cdots$ & 255.1 & 16.0 & 6.0 & 16.0 & $\cdots$ & $\cdots$ \\
\hline 156 & $G W-03 S$ & $\cdots$ & 252.4 & 18.4 & 8.4 & 18.4 & $-\cdot$ & $-\cdot$ \\
\hline 157 & $G W-04 S$ & $\cdots$ & 255.6 & 15.4 & 5.4 & 15.4 & $\cdots$ & $-\cdot$ \\
\hline 158 & GW-05S & -- & 264.2 & 17.0 & 7.0 & 17.0 & -- & $\cdots$ \\
\hline 160 & HAMP B1 & $\cdots$ & 266.3 & 20.0 & 10.0 & 20.0 & $\cdots$ & $\cdots$ \\
\hline 161 & HAMPB - 2 & $\cdots$ & 271.1 & 20.0 & 10.0 & 20.0 & -- & $\cdots$ \\
\hline 162 & HAMPB3 & - & 258.9 & 30.0 & 20.0 & 30.0 & -- & -- \\
\hline 163 & $M I-2$ & 253.94 & 252.9 & 49.0 & 42.0 & 47.0 & -- & $\cdots$ \\
\hline 164 & MI - 3 & 257.28 & 254.5 & 49.0 & 44.0 & 49.0 & - & $\cdots$ \\
\hline 165 & MI - 4 & 257.49 & 255.0 & 48.0 & 39.0 & 49.0 & -- & $\cdots$ \\
\hline 166 & MI - 5 & 255.89 & 255.2 & 49.0 & 39.0 & 49.0 & $\cdots$ & $\cdots$ \\
\hline 167 & MI - 6 & 255.66 & 255.1 & - & $\cdots$ & - & $\cdots$ & $\cdots$ \\
\hline 168 & $M I-6 A$ & - & 259.5 & $\cdots$ & $\cdots$ & - & $\cdots$ & $\cdots$ \\
\hline 169 & MI - 9 & 265.05 & 263.8 & $\cdots$ & -- & - & -- & $\cdots$ \\
\hline 170 & MI - 14 & $\cdots$ & 260.0 & $\cdots$ & - & - & $\cdots$ & $\cdots$ \\
\hline 171 & MI - 29 & 269.63 & 268.5 & 51.5 & 31.5 & 51.5 & 51.50 & $\cdots$ \\
\hline 172 & MI - 40 & 257.40 & 256.1 & - & - & - & - & $\cdots$ \\
\hline 173 & H12 - 71 & - & 250.0 & 36.0 & 36.0 & 36.0 & $-\cdot$ & 36.00 \\
\hline 174 & H11-71 & $\cdots$ & 241.6 & 35.0 & 25.0 & 35.0 & $\cdots$ & 39.00 \\
\hline 175 & H9 - 71 & $\cdots$ & 250.8 & 25.0 & 20.0 & 25.0 & $\cdots$ & 28.50 \\
\hline 176 & Н8 - 71 & $\cdots$ & 250.0 & 25.0 & 20.0 & 25.0 & $\cdots$ & 32.00 \\
\hline 177 & H6- 71 & - & 249.5 & 16.0 & 16.0 & 16.0 & -- & 16.00 \\
\hline 178 & H7-71 & - & 246.9 & 15.0 & 15.0 & 15.0 & - & 15.00 \\
\hline 179 & H10-71 & $\cdots$ & 250.9 & 28.0 & 18.0 & 28.0 & -- & 34.00 \\
\hline 180 & H5-71 & $\cdots$ & 250.5 & 28.0 & 23.0 & 28.0 & $\cdots$ & 31.00 \\
\hline 181 & - & $\cdots$ & 247.2 & - & - & - & $\cdots$ & 25.00 \\
\hline 182 & $\cdots$ & $\cdots$ & 266.9 & $\cdots$ & $\cdots$ & $\cdots$ & -- & 20.00 \\
\hline 183 & B- 61 & $\cdots$ & 239.9 & -- & $\cdots$ & -- & -- & 23.00 \\
\hline 184 & - & $\cdots$ & 260.7 & - & -- & $\cdots$ & $\cdots$ & - \\
\hline 185 & -- & $\cdots$ & 229.6 & $\cdots$ & $\cdots$ & $\cdots$ & $\cdots$ & $\cdots$ \\
\hline 186 & $\cdots$ & $\cdots$ & 230.1 & $\cdots$ & $\cdots$ & $\cdots$ & $\cdots$ & -- \\
\hline 187 & - & $\cdots$ & 220.0 & - & - & - & - & $\cdots$ \\
\hline 188 & MOA- 25 & $\cdots$ & 262.0 & 60.0 & 50.0 & 60.0 & 72.00 & $\cdots$ \\
\hline 189 & MOA- 35 & -- & 265.2 & - & $\cdots$ & - & 12.00 & $\cdots$ \\
\hline 190 & MOA- 37 & -- & 260.0 & $\cdots$ & -- & $\cdots$ & 13.00 & $\cdots$ \\
\hline 191 & MOA- 38 & $\cdots$ & 270.0 & $\cdots$ & $\cdots$ & - & 14.00 & - \\
\hline 192 & - & -- & 266.7 & -- & $\cdots$ & -- & - & 12.00 \\
\hline 193 & MOW- 15 & - & 260.0 & $\cdots$ & $\cdots$ & - & $\cdots$ & $\cdots$ \\
\hline 194 & MOW- 58 & $\cdots$ & 268.7 & 63.0 & 54.0 & 63.0 & 76.00 & $\cdots$ \\
\hline 195 & MOW- 64 & $\cdots$ & 260.0 & 49.0 & 41.0 & 49.0 & 76.00 & $\cdots$ \\
\hline 196 & MOW- 65 & $\cdots$ & 260.0 & 62.0 & 54.0 & 62.0 & 73.00 & $\cdots$ \\
\hline 197 & MOW- 66 & -- & 252.8 & 33.0 & 27.0 & 33.0 & 37.00 & $\cdots$ \\
\hline
\end{tabular}


Appendix 1. Information on well construction for selected wells in Milford, New Hampshire--Continued [altitude in feet above sea level; depth in feet below land surface; - ., no data]

\begin{tabular}{|c|c|c|c|c|c|c|c|c|}
\hline \multirow{2}{*}{$\begin{array}{c}\text { Well } \\
\text { number } \\
\text { on plate }\end{array}$} & \multirow[t]{2}{*}{ well name } & \multicolumn{2}{|c|}{ Altitude of } & \multicolumn{5}{|c|}{ Depth } \\
\hline & & $\begin{array}{l}\text { measurement } \\
\text { point }\end{array}$ & $\begin{array}{c}\text { land } \\
\text { surface }\end{array}$ & of well & $\begin{array}{l}\text { to top of } \\
\text { screen }\end{array}$ & $\begin{array}{l}\text { to bottom } \\
\text { of screen }\end{array}$ & $\begin{array}{c}\text { to } \\
\text { refusal }\end{array}$ & $\begin{array}{c}\text { to } \\
\text { bedrock }\end{array}$ \\
\hline 198 & MOW- 67 & $\cdots$ & 249.8 & 43.0 & 37.0 & 43.0 & 45.00 & -- \\
\hline 199 & MOW- 68 & -- & 245.0 & 42.0 & 36.0 & 42.0 & 53.00 & -- \\
\hline 200 & MOW - 25 & $\cdots$ & 259.7 & $\cdots$ & - & $\cdots$ & 4.00 & - \\
\hline 201 & MOW-26 & -- & 260.0 & -- & $\cdots$ & $\cdots$ & 14.00 & $\cdots$ \\
\hline 202 & MOW-19 & -- & 260.8 & - & $\cdots$ & $\cdots$ & $\ldots$ & $\cdots$ \\
\hline 203 & MI - 63 & 267.64 & 266.6 & 64.0 & 24.0 & 64.0 & - & $\cdots$ \\
\hline 204 & MI - 13 & 251.42 & 249.6 & 18.0 & 12.0 & 18.0 & 33.00 & $\cdots$ \\
\hline 205 & HAMP - GW4 & - & 270.5 & - & - & $\cdots$ & - & $\cdots$ \\
\hline 206 & RB - 39 & $\cdots$ & 262.5 & $\cdots$ & - & $\cdots$ & $\cdots$ & - \\
\hline 207 & $R B-38$ & - & 259.7 & 13.0 & -- & $\cdots$ & -- & $\cdots$ \\
\hline 208 & FH- 5 & 263.00 & 268.0 & 65.0 & 50.0 & 65.0 & - & - \\
\hline 209 & $M W-1 C$ & 281.28 & 279.5 & 61.1 & 51.1 & 61.1 & $\cdots$ & 62.00 \\
\hline 210 & $M W-2 B$ & 269.19 & 266.4 & 80.7 & 70.7 & 80.7 & -- & - - \\
\hline 212 & $M W-4 B$ & 268.59 & 266.7 & 55.8 & 45.8 & 55.8 & - & 43.20 \\
\hline 213 & $M W-5 B$ & 269.61 & 267.6 & 60.4 & 50.4 & 60.4 & $\cdots$ & 61.35 \\
\hline 214 & $M W-6 B$ & 268.95 & 267.1 & 66.8 & 56.8 & 66.8 & $\cdots$ & 69.40 \\
\hline 215 & $M W-7 B$ & 264.29 & 262.5 & 55.6 & 45.6 & 55.6 & - & 58.60 \\
\hline 216 & $M W-8 B$ & 263.80 & 261.8 & 67.0 & 57.0 & 67.0 & -- & 90.00 \\
\hline 217 & $M W-9 C$ & 268.09 & 266.3 & 90.0 & 79.0 & 90.0 & - & 94.00 \\
\hline 218 & $M W-10 C$ & 264.74 & 262.8 & 91.5 & 81.5 & 91.5 & - & 91.60 \\
\hline 219 & $M W-11 R$ & 262.47 & 261.0 & 64.0 & 52.0 & 64.0 & -- & 65.00 \\
\hline 220 & $M W-12 A$ & 265.96 & 264.0 & 34.8 & 25.0 & 35.0 & -- & - - \\
\hline 221 & $M W-13 B$ & 259.35 & 257.9 & 58.0 & 48.0 & 58.0 & - & 64.00 \\
\hline 222 & $M W-14 R$ & 255.50 & 253.8 & 108.8 & 50.0 & 60.0 & - & 60.00 \\
\hline 223 & $M W-15 A$ & 258.53 & 256.8 & 27.5 & 12.5 & 27.5 & $\cdots$ & - - \\
\hline 225 & $M W-26$ & 271.11 & 268.7 & 13.0 & 3.0 & 13.0 & - & -- \\
\hline 226 & $M W-25$ & 273.12 & 270.5 & 12.0 & 4.0 & 12.0 & $\cdots$ & - - \\
\hline 228 & $M W-3$ & 270.54 & 268.7 & 34.1 & 11.5 & 21.5 & -- & 21.50 \\
\hline 231 & $M W-18 A$ & 269.78 & 267.9 & 82.0 & 44.5 & 54.5 & - & - \\
\hline 233 & $M W-16 A$ & 270.12 & 267.5 & 26.9 & 16.9 & 26.9 & $\cdots$ & $\cdots$ \\
\hline 234 & $M W-28$ & 275.42 & 276.0 & 15.0 & 5.0 & 15.0 & $\therefore$ & $\ldots$ \\
\hline 235 & MW - 27 & 275.78 & 273.8 & 15.3 & 5.0 & 15.0 & - & 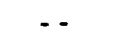 \\
\hline 237 & $M W-23 A$ & 267.51 & 265.4 & 30.0 & 20.0 & 30.0 & - & - \\
\hline 240 & $\mathrm{FH}-10(\mathrm{FH}-5-\mathrm{OBS} 1)$ & 268.01 & 267.3 & 63.0 & 58.0 & 63.0 & -- & $\cdots$ \\
\hline 242 & FH - 9 & 269.83 & 268.3 & 52.0 & - & 52.0 & - & $\cdots$ \\
\hline 244 & RW6 & -- & - & $\cdots$ & $\cdots$ & $\cdots$ & $-\cdot$ & $\cdots$ \\
\hline 245 & RW3 & - & -2.0 & 420.0 & 111.0 & 420.0 & $\cdots$ & -- \\
\hline 247 & RW1 & - & -2.0 & 340.0 & 59.0 & 340.0 & $\cdots$ & - \\
\hline 248 & RW2 & - & - & - - & $\cdots$ & $\cdots$ & $\cdots$ & $\cdots$ \\
\hline 249 & CASSSARINO & $\cdots$ & 267.9 & 12.5 & $\cdots$ & 12.5 & $\cdots$ & - \\
\hline 250 & SPZ - 1 & 259.17 & 257.4 & 7.0 & 2.0 & 7.0 & - & - \\
\hline 251 & SP- 7 & 258.66 & 258.2 & 9.5 & 4.5 & 9.5 & $\cdots$ & $\cdots$ \\
\hline 252 & SP- 6 & 261.05 & 260.0 & 8.0 & 3.0 & 8.0 & $\cdots$ & - \\
\hline 255 & $M W-24 A$ & 259.67 & 257.1 & 29.5 & 19.5 & 29.5 & -- & $\cdots$ \\
\hline 258 & $M W-17 A$ & 267.05 & 264.4 & 29.8 & 19.8 & 29.8 & -- & - \\
\hline 262 & MW-29 & 260.90 & 260.4 & 14.5 & 2.5 & 12.5 & - & - \\
\hline 264 & $M W-20 A$ & 263.23 & 260.8 & 25.2 & 15.2 & 25.2 & -- &.- \\
\hline
\end{tabular}


Appendix 1. Information on well construction for selected wells in Milford, New Hampshire--Continued [altitude in feet above sea level; depth in feet below land surface; -., no data]

\begin{tabular}{|c|c|c|c|c|c|c|c|c|}
\hline \multirow{2}{*}{$\begin{array}{c}\text { Well } \\
\text { number } \\
\text { on plate }\end{array}$} & \multirow[t]{2}{*}{ Well name } & \multicolumn{2}{|c|}{ Altitude of } & \multicolumn{5}{|c|}{ Depth } \\
\hline & & $\begin{array}{l}\text { measurement } \\
\text { point }\end{array}$ & $\begin{array}{c}\text { land } \\
\text { surface }\end{array}$ & of well & $\begin{array}{l}\text { to top of } \\
\text { screen }\end{array}$ & $\begin{array}{l}\text { to bottom } \\
\text { of screen }\end{array}$ & $\begin{array}{c}\text { to } \\
\text { refusal }\end{array}$ & $\begin{array}{c}\text { to } \\
\text { bedrock }\end{array}$ \\
\hline 267 & $S P-4$ & 258.63 & 257.1 & 7.5 & 2.5 & 7.5 & -- & -- \\
\hline 268 & SP- 3 & 256.30 & 255.3 & 9.5 & 4.5 & 9.5 & $\cdots$ & $\cdots$ \\
\hline 269 & $P-9 A$ & 254.73 & 253.1 & 8.0 & 7.0 & 8.0 & $\cdots$ & $\cdots$ \\
\hline 270 & P-9B & 255.01 & 252.6 & 10.2 & 9.2 & 10.2 & $\cdots$ & $\cdots$ \\
\hline 271 & P - 15 & 252.08 & 251.4 & 8.0 & 7.0 & 8.0 & -- & $\cdots$ \\
\hline 273 & HP - 1 & 254.51 & 252.3 & 6.0 & 1.0 & 6.0 & -- & -- \\
\hline 274 & HP - 2 & 253.24 & 251.0 & 6.5 & 1.5 & 6.5 & -- & -- \\
\hline 275 & HP - 3 & 253.53 & 251.1 & 6.5 & 1.5 & 6.5 & $\cdots$ & -- \\
\hline 276 & $P-10$ & 252.70 & 250.4 & 8.5 & 7.5 & 8.5 & -- & $\cdots$ \\
\hline 277 & P-11 & 254.54 & 252.5 & 8.5 & 7.5 & 8.5 & -- & -- \\
\hline 278 & $M W-21 A$ & 261.27 & 259.2 & 13.8 & 3.8 & 13.8 & -- & -- \\
\hline 279 & SP- 2 & 251.94 & 249.9 & 6.0 & 1.0 & 6.0 & $\cdots$ & -- \\
\hline 280 & $P-16$ & 260.43 & 258.3 & 13.0 & 12.0 & 13.0 & $\cdots$ & - \\
\hline 281 & MW - 34 & 260.91 & 258.5 & 19.6 & 9.5 & 19.5 & $\cdots$ & 20.50 \\
\hline 282 & P-17A & 252.54 & 250.6 & 9.0 & 8.0 & 9.0 & - & - \\
\hline 283 & $P-17 B$ & 253.66 & 252.6 & 13.0 & 12.0 & 13.0 & - & $\cdots$ \\
\hline 284 & FERGUSON & 280.08 & 278.3 & 23.0 & - & 23.0 & $-\cdot$ & $\cdots$ \\
\hline 285 & SPZ-2 & 252.23 & 250.2 & 8.5 & 3.5 & 8.5 & -- & -- \\
\hline 287 & GORMAN & 271.45 & 270.4 & 22.0 & -- & 22.0 & $-\cdot$ & -- \\
\hline 288 & FH - $28 \quad($ PFH -OBS 6$)$ & 248.81 & 248.1 & 23.0 & $\cdots$ & 23.0 & -- & -- \\
\hline 289 & FH - 29 & 250.07 & 247.8 & 33.9 & -- & 33.9 & $-\cdot$ & -- \\
\hline 290 & $S P-18$ & 250.17 & 248.2 & 7.5 & 4.5 & 7.5 & $\cdots$ & $\cdots$ \\
\hline 291 & SP-11 & 249.67 & 247.7 & 9.5 & 8.5 & 9.5 & $\cdots$ & $\cdots$ \\
\hline 292 & FH - 30 & 250.69 & 248.3 & 23.0 & -- & 23.0 & $\cdots$ & $\cdots$ \\
\hline 293 & $M W-22 A$ & 252.52 & 250.2 & 23.3 & 13.8 & 23.8 & $\cdots$ & - \\
\hline 294 & $M W-22 B$ & 252.77 & 250.1 & 43.7 & 33.5 & 43.5 & $\cdots$ & 47.00 \\
\hline 295 & $P-13$ & 250.84 & 248.3 & 8.5 & 7.5 & 8.5 & $\cdots$ & - \\
\hline 296 & $M W-32 A$ & 250.46 & 247.9 & 17.7 & 7.0 & 17.0 & $\cdots$ & - - \\
\hline 297 & $M W-32 B$ & 251.23 & 248.3 & 41.3 & 31.8 & 41.8 & - & 43.50 \\
\hline 299 & HM - 1 & 262.88 & 269.2 & 62.3 & 52.3 & 62.3 & $\cdots$ & - \\
\hline 301 & FH - 11 & 268.08 & 267.4 & 62.0 & - & 62.0 & - & -- \\
\hline 302 & FH - 19 & 256.17 & $-\cdot$ & $\cdots$ & $\cdots$ & -- & $\cdots$ & $\cdots$ \\
\hline 304 & SP- 5 & 257.07 & 255.3 & 7.5 & 2.5 & 7.5 & $-\cdot$ & $\cdots$ \\
\hline 305 & FH - 18 & 255.01 & $-\cdot$ & $\cdots$ & - & $\cdots$ & - & $\cdots$ \\
\hline 306 & MW - 33 & 253.89 & 251.8 & 53.1 & 41.5 & 51.5 & $\cdots$ & 52.50 \\
\hline 307 & $M W-1 A$ & 281.26 & 279.7 & 17.0 & 5.0 & 17.0 & $-\cdot$ & - \\
\hline 308 & $M W-13 A$ & 258.04 & 257.9 & 33.9 & 23.9 & 33.9 & $\cdots$ & $\cdots$ \\
\hline 309 & $M W-1 B$ & 281.38 & 279.5 & 45.4 & 35.4 & 45.4 & $\cdots$ & $\cdots$ \\
\hline 310 & $M W-2 A$ & 269.32 & 266.6 & 41.0 & 29.0 & 39.0 & - & $\cdots$ \\
\hline 311 & $M W-2 R$ & 268.95 & 266.2 & 164.0 & 134.0 & 164.0 & -- & 115.50 \\
\hline 312 & $M W-4 A$ & 268.34 & 266.5 & 29.7 & 19.7 & 29.7 & -- & -- \\
\hline 313 & $M W-5 A$ & 269.71 & 267.6 & 40.0 & 28.0 & 38.0 & $\cdots$ & $\cdots$ \\
\hline 314 & $M W-7 A$ & 264.40 & 262.3 & 13.2 & 3.2 & 13.2 & $\cdots$ & $\cdots$ \\
\hline 315 & $M W-8 A$ & 263.91 & 262.0 & 20.0 & 4.5 & 16.5 & - & $\cdots$ \\
\hline 316 & $M W-10 A$ & 263.77 & 262.2 & 29.0 & 19.0 & 29.0 & -- & -- \\
\hline 317 & $M W-10 B$ & 263.55 & 262.2 & 54.0 & 44.0 & 54.0 & $\cdots$ & $\cdots$ \\
\hline 318 & $M W-11 A$ & 262.78 & 260.9 & 30.5 & 20.5 & 30.5 & $\cdots$ & $\cdots$ \\
\hline
\end{tabular}


Appendix 1. Information on well construction for selected wells in Milford, New Hampshire--Continued [altitude in feet above sea level; depth in feet below land surface; - - no data]

\begin{tabular}{|c|c|c|c|c|c|c|c|c|}
\hline \multirow[t]{2}{*}{$\begin{array}{c}\text { Well } \\
\text { number } \\
\text { on plate }\end{array}$} & \multirow[t]{2}{*}{ Well name } & \multicolumn{2}{|c|}{ Altitude of } & \multicolumn{5}{|c|}{ Depth } \\
\hline & & $\begin{array}{l}\text { measurement } \\
\text { point }\end{array}$ & $\begin{array}{l}\text { land } \\
\text { surface }\end{array}$ & of well & $\begin{array}{l}\text { to top of } \\
\text { screen }\end{array}$ & $\begin{array}{l}\text { to bottom } \\
\text { of screen }\end{array}$ & $\begin{array}{c}\text { to } \\
\text { refusal }\end{array}$ & $\begin{array}{c}\text { to } \\
\text { bedrock }\end{array}$ \\
\hline 319 & MW - 11B & 262.83 & 261.0 & 64.3 & 52.3 & 64.3 & -- & -- \\
\hline 320 & $M W-12 B$ & 265.61 & 264.0 & 66.0 & 56.0 & 66.0 & $\cdots$ & 66.00 \\
\hline 321 & $M W-16 B$ & 269.87 & 267.6 & 49.6 & 39.6 & 49.6 & $-\cdot$ & - \\
\hline 322 & $M W-17 B$ & 267.06 & 264.6 & 62.7 & 52.4 & 62.4 & $\cdots$ & - - \\
\hline 323 & $M W-17 C$ & 267.28 & 264.7 & 95.0 & 85.0 & 95.0 & -- & 99.30 \\
\hline 324 & $M W-18 B$ & 270.30 & 268.0 & 90.8 & 72.0 & 82.0 & - & 82.00 \\
\hline 326 & $M W-19 A$ & 263.68 & 261.6 & 33.5 & 23.5 & 33.5 & $\cdots$ & - \\
\hline 327 & $M W-19 B$ & 263.44 & 260.9 & 49.0 & 39.0 & 49.0 & -- & 35.00 \\
\hline 328 & $M W-20 B$ & 263.03 & 260.7 & 61.5 & 35.0 & 45.0 & $\cdots$ & 47.50 \\
\hline 329 & $M W-21 B$ & 261.77 & 259.3 & 30.0 & 20.0 & 30.0 & $\cdots$ & - - \\
\hline 330 & $M W-21 C$ & 261.34 & 259.4 & 54.4 & 44.1 & 54.1 & $\cdots$ & 63.75 \\
\hline 331 & $M W-23 B$ & 267.40 & 265.3 & 99.0 & 48.0 & 58.0 & $\cdots$ & - \\
\hline 332 & $M W-23 C$ & 267.34 & 265.3 & 99.0 & 84.3 & 94.3 & - & 106.00 \\
\hline 333 & $M W-24 B$ & 259.39 & 256.8 & 41.0 & 31.0 & 41.0 & $\cdots$ & 40.50 \\
\hline 334 & $M W-31$ & 251.87 & 250.1 & - - & - & - - & - & - \\
\hline 335 & P-1 & 279.26 & 276.6 & 14.9 & 13.9 & 14.9 & - & -- \\
\hline 336 & P-2 & 271.32 & 268.6 & 18.0 & 17.0 & 18.0 & - & - \\
\hline 337 & WLR4 & 257.38 & 251.3 & 4.4 & 4.0 & 5.0 & $\cdots$ & $\cdots$ \\
\hline 338 & $P-14$ & 248.69 & 246.7 & 8.0 & 7.0 & 8.0 & - & - \\
\hline 339 & SP-9 & 261.16 & 259.4 & 6.5 & 1.5 & 6.5 & $\cdots$ & $\cdots$ \\
\hline 340 & $S P-10$ & 263.92 & 262.4 & 6.0 & 1.0 & 6.0 & $\cdots$ & $\cdots$ \\
\hline 341 & $M W-14 B$ & 255.13 & 253.3 & 59.6 & 50.0 & 60.0 & $\cdots$ & - \\
\hline 342 & $M W-15 B$ & 258.61 & 257.0 & 39.4 & 29.4 & 36.4 & $\cdots$ & 27.50 \\
\hline 344 & $M W-16 C$ & 269.74 & 267.4 & 83.2 & 73.2 & 83.2 & $\cdots$ & 87.50 \\
\hline 345 & $M W-16 R$ & - & - - & - & - & - & $\cdots$ & 87.50 \\
\hline 347 & MW4R & 267.94 & 266.4 & 98.0 & 64.0 & 98.0 & $\cdots$ & 45.00 \\
\hline 348 & $M W-6 A$ & 269.11 & 267.0 & 20.0 & 8.0 & 20.0 & - & - \\
\hline 349 & $M W-14 A$ & 254.65 & 253.4 & 29.0 & 19.0 & 29.0 & $\cdots$ & $\cdots$ \\
\hline 351 & MW-9A & 267.76 & 266.1 & 40.7 & 30.7 & 40.7 & $\cdots$ & -- \\
\hline 352 & MW-9B & 267.87 & 266.1 & 68.2 & 58.2 & 68.2 & $\cdots$ & -- \\
\hline 353 & $\mathrm{FH}-17$ & 272.44 & $\cdots$ & $\cdots$ & - & -- & $\cdots$ & $\cdots$ \\
\hline 354 & PFH production Well & 251.68 & 249.2 & 40.0 & 30.0 & 40.0 & $\cdots$ & -- \\
\hline 356 & $-\cdot$ & 250.05 & 247.4 & - & -- & -- & $\cdots$ & $\cdots$ \\
\hline 357 & $\cdots$ & 249.97 & 247.4 & $\cdots$ & $\cdots$ & $\cdots$ & $\cdots$ & $\cdots$ \\
\hline 358 & -- & 250.03 & 247.2 & $\cdots$ & $-\cdot$ & $\cdots$ & $\cdots$ & $-\cdot$ \\
\hline 359 & $\cdots$ & 249.86 & 248.5 & 24.8 & -- & 24.8 & $\cdots$ & -- \\
\hline 360 & - & 251.03 & 247.1 & 34.5 & $\cdots$ & 34.5 & $\cdots$ & -- \\
\hline 361 & P- 12 & - & -2.0 & 10.0 & 9.0 & 10.0 & $\cdots$ & $\cdots$ \\
\hline 362 & USGS-DISK & 250.02 & -- & $\cdots$ & $\cdots$ & - & $\cdots$ & $\cdots$ \\
\hline 364 & $\cdots$ & 264.93 & 262.5 & - & $\cdots$ & -- & $\cdots$ & $\cdots$ \\
\hline 365 & MW - 15R & -- & $\ldots$ & - & $\cdots$ & $\cdots$ & $\cdots$ & $\cdots$ \\
\hline 366 & MW - 30 & $\cdots$ & $\cdots$ & $\cdots$ & $\cdots$ & $\cdots$ & $\cdots$ & -- \\
\hline 367 & M261942 & $\cdots$ & $\cdots$ & -- & -- & $\cdots$ & $\cdots$ & $\cdots$ \\
\hline 368 & BMc821934 & $\cdots$ & $\cdots$ & $-\cdot$ & $-\cdot$ & $\cdots$ & $\cdots$ & $\cdots$ \\
\hline 369 & FHwoods & 266.46 & 266.1 & $-\cdot$ & $\cdots$ & $\cdots$ & $\cdots$ & $\cdots$ \\
\hline 374 & $\mathrm{FH}-26$ & $\cdots$ & - - & $\cdots$ & $\cdots$ & $\cdots$ & $\cdots$ & $-\cdot$ \\
\hline 375 & We11 near FH19 & -- & $\cdots$ & $-\cdot$ & $\cdots$ & -- & $\cdots$ & - \\
\hline
\end{tabular}


APPENDIX 2 
Appendix 2. River stage from staff gages on the Souhegan River and tributaries in Milford, New Hampshire

[Positive gage readings greater than measuring point; negative values less than measuring point; observed means are from all water surface elevations shown; water surface elevations are instantaneous; $M . P .$. measuring point; ft, feet; Elev.., elevation]

\begin{tabular}{|c|c|c|c|c|c|c|c|c|c|c|c|}
\hline $\begin{array}{l}\text { Well } \\
\text { Number }\end{array}$ & $\begin{array}{l}\text { M.P. } \\
\text { Elev. } \\
\text { (ft) }\end{array}$ & $\begin{array}{l}\text { Gage } \\
\text { Read- } \\
\text { ing }\end{array}$ & $\begin{array}{c}\text { Water } \\
\text { Surface } \\
\text { Elev. (ft) }\end{array}$ & $\begin{array}{c}\text { Measure } \\
\text { Date }\end{array}$ & $\begin{array}{l}\text { Observed } \\
\text { Mean } \\
\text { (ft) }\end{array}$ & $\begin{array}{l}\text { Well } \\
\text { Numbe }\end{array}$ & $\begin{array}{l}\text { M.P. } \\
\text { Elev. } \\
\text { (ft) }\end{array}$ & $\begin{array}{r}\text { Gage } \\
\text { Readi } \\
\text { (ft) }\end{array}$ & $\begin{array}{l}\text { Wat } \\
\text { Surf } \\
\text { Elev }\end{array}$ & $\begin{array}{lc}\text { er } & \text { Measure } \\
\text { ace } & \text { Date } \\
\text {. (ft) } & \end{array}$ & $\begin{array}{l}\text { Observed } \\
\text { Mean } \\
\text { (ft) }\end{array}$ \\
\hline $\begin{array}{l}\text { WLR - } 1 \\
(391)\end{array}$ & $\begin{array}{l}269.23 \\
269.23 \\
269.23 \\
269.23 \\
269.23 \\
269.23 \\
269.23 \\
269.23 \\
269.23 \\
269.23 \\
269.23 \\
269.23 \\
269.23 \\
269.2 \\
269.23 \\
269.23 \\
269.23 \\
269.23 \\
269.23 \\
269.23 \\
269.23 \\
269.23 \\
269.23 \\
269.23 \\
269.23 \\
269.23 \\
269.23 \\
269.23 \\
269.23 \\
269.23 \\
272.41 \\
272.41 \\
272.41 \\
272.41 \\
272.41 \\
272.41 \\
272.41 \\
272.41\end{array}$ & $\begin{array}{r}-0.30 \\
-0.20 \\
1.88 \\
1.83 \\
1.35 \\
1.28 \\
1.66 \\
0.22 \\
1.21 \\
0.24 \\
-0.86 \\
-1.20 \\
\\
-1.15 \\
-1 \\
-0.96 \\
\\
-0.63 \\
-0.89 \\
-0.89 \\
-0.49 \\
-0.89 \\
-0.17 \\
0.36 \\
1.30 \\
1.24 \\
0.09 \\
1.20 \\
0.58 \\
0.22 \\
0.24 \\
0.72 \\
0.18 \\
-3.25 \\
-3.24 \\
-4.34 \\
-4.45 \\
-4.27 \\
-4.46 \\
4.60 \\
4.51\end{array}$ & $\begin{array}{l}268.93 \\
269.03 \\
271.11 \\
271.06 \\
270.58 \\
270.51 \\
270.89 \\
269.45 \\
270.44 \\
269.47 \\
268.37 \\
268.03 \\
268.08 \\
\\
268.26 \\
268.56 \\
268.34 \\
268.74 \\
268.34 \\
269.06 \\
269.59 \\
270.53 \\
270.47 \\
269.32 \\
270.43 \\
269.81 \\
269.45 \\
269.47 \\
269.95 \\
269.41 \\
269.16 \\
269.17 \\
268.07 \\
267.96 \\
268.14 \\
267.95 \\
267.81 \\
267.90\end{array}$ & $\begin{array}{l}10 / 18 / 90 \\
10 / 19 / 90 \\
04 / 05 / 94 \\
04 / 05 / 94 \\
04 / 12 / 94 \\
04 / 13 / 94 \\
04 / 14 / 94 \\
05 / 04 / 94 \\
05 / 09 / 94 \\
05 / 14 / 94 \\
06 / 16 / 94 \\
07 / 20 / 94 \\
08 / 24 / 94 \\
09 / 21 / 94 \\
09 / 29 / 94 \\
10 / 07 / 94 \\
10 / 11 / 94 \\
10 / 24 / 94 \\
11 / 07 / 94 \\
11 / 08 / 94 \\
11 / 21 / 94 \\
11 / 22 / 94 \\
12 / 05 / 94 \\
12 / 06 / 94 \\
10 \\
12 / 19 / 94 \\
01 / 18 / 95 \\
01 / 26 / 95 \\
02 / 27 / 95 \\
02 / 27 / 95 \\
03 / 22 / 95 \\
03 / 27 / 95 \\
04 / 24 / 95 \\
05 / 22 / 95 \\
06 / 28 / 95 \\
08 / 01 / 95 \\
08 / 03 / 95 \\
08 / 29 / 95 \\
09 / 29 / 95 \\
09 / 27 / 95\end{array}$ & 269.29 & $\begin{array}{l}\text { WLR2 } \\
(392)\end{array}$ & $\begin{array}{l} \\
262.85 \\
262.85 \\
262.85 \\
262.85\end{array}$ & $\begin{array}{l} \\
-0.40 \\
-0.39 \\
-0.39 \\
-0.40\end{array}$ & $\begin{array}{l} \\
262.45 \\
262.46 \\
262.46 \\
262.45\end{array}$ & $\begin{array}{l}10 / 18 / 90 \\
10 / 19 / 90 \\
04 / 05 / 94 \\
04 / 05 / 94 \\
04 / 12 / 94 \\
04 / 13 / 94 \\
04 / 14 / 94 \\
05 / 04 / 94 \\
05 / 09 / 94 \\
05 / 14 / 94 \\
06 / 16 / 94 \\
07 / 20 / 94 \\
08 / 24 / 94 \\
09 / 21 / 94 \\
09 / 29 / 94 \\
10 / 07 / 94 \\
10 / 11 / 94 \\
10 / 24 / 94 \\
11 / 07 / 94 \\
11 / 08 / 94 \\
11 / 21 / 94 \\
11 / 22 / 94 \\
12 / 05 / 94 \\
12 / 06 / 94 \\
10 \\
12 / 19 / 94 \\
01 / 18 / 95 \\
01 / 26 / 95 \\
02 / 27 / 95 \\
02 / 27 / 95 \\
03 / 22 / 95 \\
03 / 27 / 95 \\
04 / 24 / 95 \\
05 / 22 / 95 \\
06 / 28 / 95 \\
08 / 01 / 95 \\
08 / 03 / 95 \\
08 / 29 / 95 \\
09 / 14 / 95 \\
09 / 27 / 95\end{array}$ & 262.47 \\
\hline $\begin{array}{l}\text { WLR3 } \\
(65)\end{array}$ & $\begin{array}{l}255.16 \\
255.16 \\
255.16 \\
255.16 \\
255.16 \\
255.16 \\
255.16 \\
255.16 \\
255.16 \\
255.16 \\
255.16 \\
255.16 \\
255.16 \\
255.16 \\
255.16 \\
255.16 \\
255.16\end{array}$ & $\begin{array}{l}0.86 \\
0.85 \\
0.53 \\
0.54 \\
0.52 \\
0.58 \\
0.54 \\
0.50 \\
0.44 \\
0.50 \\
0.88 \\
0.88 \\
0.78 \\
0.76 \\
0.72 \\
0.78 \\
0.94\end{array}$ & $\begin{array}{l}256.02 \\
256.01 \\
255.69 \\
255.70 \\
255.68 \\
255.74 \\
255.70 \\
255.66 \\
255.60 \\
255.66 \\
256.04 \\
256.04 \\
255.94 \\
255.92 \\
255.88 \\
255.94 \\
256.10\end{array}$ & $\begin{array}{l}02 / 02 / 89 \\
02 / 03 / 89 \\
04 / 14 / 89 \\
04 / 21 / 89 \\
04 / 28 / 89 \\
05 / 12 / 89 \\
06 / 16 / 89 \\
08 / 24 / 89 \\
09 / 28 / 89 \\
10 / 16 / 89 \\
04 / 12 / 94 \\
04 / 13 / 94 \\
06 / 16 / 94 \\
07 / 20 / 94 \\
08 / 24 / 94 \\
09 / 29 / 94 \\
10 / 11 / 94 \\
12 / 19 / 94 \\
01 / 18 / 95 \\
01 / 26 / 95 \\
02 / 27 / 95 \\
02 / 27 / 95 \\
03 / 22 / 95 \\
03 / 27 / 95 \\
04 / 24 / 95 \\
05 / 22 / 95 \\
06 / 28 / 95\end{array}$ & 255.87 & $\begin{array}{l}\text { WLR4 } \\
\text { (337) }\end{array}$ & $\begin{array}{l}250.78 \\
250.78 \\
250.78 \\
250.78 \\
250.78 \\
250.78 \\
250.78 \\
250.78 \\
250.78 \\
250.78 \\
250.78 \\
250.78 \\
250.78 \\
250.78 \\
250.78 \\
250.78 \\
250.78 \\
250.78 \\
250.78 \\
250.78 \\
250.78 \\
250.78 \\
250.78 \\
250.78 \\
250.78\end{array}$ & $\begin{array}{l}0.54 \\
0.47 \\
0.54 \\
0.42 \\
0.63 \\
0.45 \\
0.40 \\
0.26 \\
0.32 \\
0.81 \\
0.30 \\
1.27 \\
0.53 \\
0.66 \\
0.58 \\
0.75 \\
0.84 \\
0.86 \\
0.61 \\
0.66 \\
0.78 \\
0.68 \\
0.70 \\
0.56 \\
0.34\end{array}$ & $\begin{array}{l}251.32 \\
251.25 \\
251.32 \\
251.20 \\
251.41 \\
251.23 \\
251.18 \\
251.04 \\
251.10 \\
251.59 \\
251.08 \\
252.05 \\
251.31 \\
251.44 \\
251.36 \\
251.53 \\
251.62 \\
251.64 \\
251.39 \\
251.44 \\
251.56 \\
251.46 \\
251.48 \\
251.34 \\
251.12\end{array}$ & $\begin{array}{l}02 / 02 / 89 \\
02 / 03 / 89 \\
04 / 14 / 89 \\
04 / 21 / 89 \\
04 / 28 / 89 \\
05 / 12 / 89 \\
06 / 16 / 89 \\
08 / 24 / 89 \\
09 / 28 / 89 \\
10 / 16 / 89 \\
04 / 12 / 94 \\
04 / 13 / 94 \\
06 / 16 / 94 \\
07 / 20 / 94 \\
08 / 24 / 94 \\
09 / 29 / 94 \\
10 / 11 / 94 \\
12 / 19 / 94 \\
01 / 18 / 95 \\
01 / 26 / 95 \\
02 / 27 / 95 \\
02 / 27 / 95 \\
03 / 22 / 95 \\
03 / 27 / 95 \\
04 / 24 / 95 \\
05 / 22 / 95 \\
06 / 28 / 95\end{array}$ & 251.34 \\
\hline
\end{tabular}


Appendix 2. River stage from staff gages on the Souhegan River and tributaries in Milford, New Hampshire - - Continued

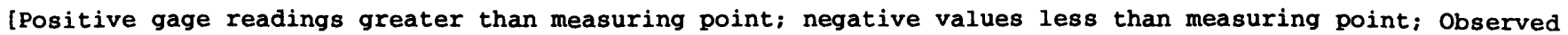
means are from all water surface elevations shown; Water surface elevations are instantaneous; $M . P .$, measuring point; ft, feet; Elev., elevation]

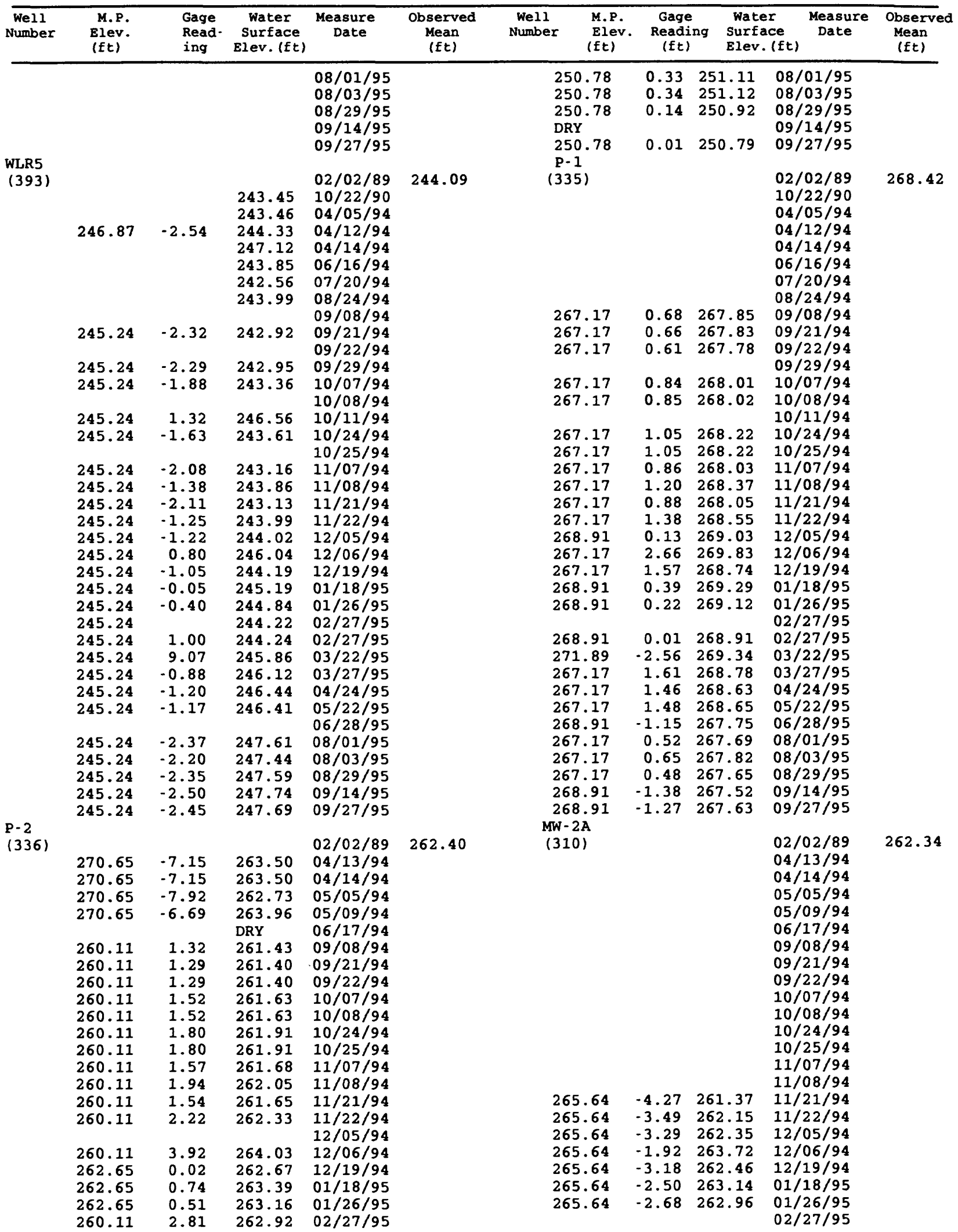


Appendix 2. River stage from staff gages on the Souhegan River and tributaries in Milford, New Hampshire.-Continued

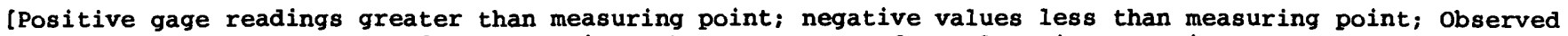
means are from all water surface elevations shown; Water surface elevations are instantaneous; $M . P$. measuring point; ft, feet; Elev., elevation]

\begin{tabular}{|c|c|c|c|c|c|c|c|c|c|c|c|}
\hline $\begin{array}{l}\text { WelI } \\
\text { Number }\end{array}$ & $\begin{array}{l}\text { M.P. } \\
\text { EIev. } \\
\text { (ft) }\end{array}$ & $\begin{array}{l}\text { Gage } \\
\text { Read- } \\
\text { ing }\end{array}$ & $\begin{array}{c}\text { water } \\
\text { Surface } \\
\text { Elev. (ft) }\end{array}$ & $\begin{array}{c}\text { Measure } \\
\text { Date }\end{array}$ & $\begin{array}{l}\text { Observed } \\
\text { Mean } \\
(f t)\end{array}$ & $\begin{array}{l}\text { Well } \\
\text { Number }\end{array}$ & $\begin{array}{l}\text { M.P. } \\
\text { Elev. } \\
(f t)\end{array}$ & $\begin{array}{r}\text { Gage } \\
\text { Readi } \\
(f t)\end{array}$ & $\begin{array}{l}\text { Wat } \\
\text { Surf } \\
\text { Elev }\end{array}$ & $\begin{array}{ll}r & \text { Measure } \\
\text { ce } & \text { Date } \\
(f t) & \end{array}$ & $\begin{array}{l}\text { Observed } \\
\text { Mean } \\
(f t)\end{array}$ \\
\hline & $\begin{array}{l}260.11 \\
260.11 \\
262.65 \\
260.11 \\
260.11 \\
260.11 \\
260.11 \\
260.11 \\
260.11 \\
260.11 \\
260.11\end{array}$ & $\begin{array}{r}2.82 \\
3.28 \\
-0.08 \\
2.41 \\
2.43 \\
1.48 \\
1.33 \\
1.56 \\
1.29 \\
1.12 \\
1.28\end{array}$ & $\begin{array}{l}262.93 \\
263.39 \\
262.57 \\
262.52 \\
262.54 \\
261.59 \\
261.44 \\
261.67 \\
261.40 \\
261.23 \\
261.39\end{array}$ & $\begin{array}{l}02 / 27 / 95 \\
03 / 22 / 95 \\
03 / 27 / 95 \\
04 / 10 / 95 \\
04 / 24 / 95 \\
05 / 22 / 95 \\
06 / 28 / 95 \\
08 / 01 / 95 \\
08 / 03 / 95 \\
08 / 29 / 95 \\
09 / 14 / 95 \\
09 / 27 / 95\end{array}$ & & & $\begin{array}{l}.64 \\
.64 \\
.64 \\
.64 \\
.64 \\
.64 \\
.64 \\
.64\end{array}$ & $\begin{array}{r}-3.30 \\
-3.27 \\
-4.00 \\
-4.36 \\
-4.08 \\
-4.27 \\
-4.46 \\
4.29\end{array}$ & $\begin{array}{l}262.34 \\
262.37 \\
261.64 \\
261 \cdot 28 \\
261.56 \\
261.37 \\
261.18 \\
261 \cdot 35\end{array}$ & $\begin{array}{l}02 / 27 / 95 \\
03 / 22 / 95 \\
03 / 27 / 95 \\
04 / 10 / 95 \\
04 / 24 / 95 \\
05 / 22 / 95 \\
06 / 28 / 95 \\
08 / 01 / 95 \\
08 / 03 / 95 \\
08 / 29 / 95 \\
09 / 14 / 95 \\
09 / 27 / 95\end{array}$ & \\
\hline $\begin{array}{r}M W-23 \\
(237)\end{array}$ & $\begin{array}{l}261 \cdot 18 \\
261 \cdot 18 \\
261.18 \\
261.18 \\
261.18 \\
261.18 \\
261.18 \\
257.83\end{array}$ & $\begin{array}{r}-3.13 \\
-2.65 \\
-2.56 \\
-2.60 \\
-2.88 \\
-2.23 \\
-2.25 \\
2.30\end{array}$ & $\begin{array}{l}258.05 \\
258.53 \\
258.62 \\
258.57 \\
258.29 \\
258.95 \\
258.93 \\
260.13\end{array}$ & $\begin{array}{c}02 / 02 / 89 \\
09 / 21 / 94 \\
10 / 24 / 94 \\
11 / 07 / 94 \\
11 / 08 / 94 \\
11 / 21 / 94 \\
11 / 22 / 94 \\
12 / 05 / 94 \\
12 / 06 / 94 \\
\ldots\end{array}$ & 258.56 & $\begin{array}{c}\text { FH - } 27 \\
(89)\end{array}$ & $\begin{array}{l}.57 \\
.57 \\
.57 \\
.57 \\
.57\end{array}$ & $\begin{array}{l}0.66 \\
0.83 \\
0.82 \\
1.52 \\
3.34\end{array}$ & $\begin{array}{l}246.23 \\
246.40 \\
245.57 \\
246.39 \\
247.09 \\
245.57 \\
248.91 \\
245.57\end{array}$ & $\begin{array}{c}02 / 02 / 89 \\
09 / 21 / 94 \\
10 / 24 / 94 \\
11 / 07 / 94 \\
11 / 08 / 94 \\
11 / 21 / 94 \\
11 / 22 / 94 \\
12 / 05 / 94 \\
12 / 06 / 94 \\
\ldots\end{array}$ & 247.15 \\
\hline $\begin{array}{l}39-B \\
(390)\end{array}$ & $\begin{array}{l}239.39 \\
239.39 \\
239.39 \\
239.39 \\
239.39 \\
239.39 \\
239.39 \\
239.39 \\
239.39 \\
239.39 \\
239.39 \\
239.39 \\
239.39 \\
239.39 \\
239.39 \\
239.39 \\
239.39 \\
239.39 \\
239.39 \\
239.39\end{array}$ & $\begin{array}{l}1.17 \\
1.86 \\
1.88 \\
1.51 \\
1.46 \\
2.46 \\
2.47 \\
2.40 \\
2.56 \\
3.44 \\
3.18 \\
2.88 \\
3.52 \\
2.80 \\
2.49 \\
2.51 \\
1.10 \\
1.30 \\
0.94 \\
1.03\end{array}$ & $\begin{array}{l}240.56 \\
241.25 \\
241.27 \\
240.90 \\
240.85 \\
241.85 \\
241.86 \\
243.79 \\
241.95 \\
242.83 \\
242.57 \\
242.27 \\
242.91 \\
242.19 \\
241.88 \\
241.90 \\
240.49 \\
240.69 \\
240.33 \\
240.42\end{array}$ & $\begin{array}{l}12 / 19 / 94 \\
01 / 18 / 95 \\
01 / 26 / 95 \\
02 / 27 / 95 \\
03 / 13 / 95 \\
03 / 22 / 95 \\
03 / 27 / 95 \\
04 / 10 / 95 \\
04 / 24 / 95 \\
05 / 22 / 95 \\
06 / 28 / 95 \\
08 / 01 / 95 \\
08 / 03 / 95 \\
09 / 14 / 95 \\
09 / 27 / 95 \\
02 / 03 / 89 \\
04 / 14 / 89 \\
09 / 21 / 94 \\
10 / 11 / 94 \\
10 / 24 / 94 \\
11 / 07 / 94 \\
11 / 21 / 94 \\
11 / 22 / 94 \\
12 / 05 / 94 \\
12 / 06 / 94 \\
12 / 19 / 94 \\
01 / 18 / 95 \\
01 / 26 / 95 \\
02 / 27 / 95 \\
03 / 22 / 95 \\
03 / 27 / 95 \\
04 / 24 / 95 \\
05 / 22 / 95 \\
08 / 01 / 95 \\
08 / 03 / 95 \\
09 / 14 / 95 \\
09 / 27 / 95\end{array}$ & & & $\begin{array}{l}.57 \\
.57 \\
.57 \\
.57 \\
.57 \\
.57 \\
.57 \\
.57 \\
.57 \\
.57 \\
.57 \\
.57 \\
.57 \\
.57\end{array}$ & $\begin{array}{l}1.78 \\
2.76 \\
2.30 \\
1.93 \\
2.33 \\
2.55 \\
1.88 \\
1.62 \\
1.64 \\
0.70 \\
0.66 \\
0.76 \\
0.55 \\
0.60\end{array}$ & $\begin{array}{l}247.35 \\
248.33 \\
247.87 \\
247.50 \\
247.90 \\
248.12 \\
247.45 \\
247.19 \\
247.21 \\
\\
246.27 \\
246.23 \\
246.33 \\
246.12 \\
246.17\end{array}$ & $\begin{array}{l}12 / 19 / 94 \\
01 / 18 / 95 \\
01 / 26 / 95 \\
02 / 27 / 95 \\
03 / 13 / 95 \\
03 / 22 / 95 \\
03 / 27 / 95 \\
04 / 10 / 95 \\
04 / 24 / 95 \\
05 / 22 / 95 \\
06 / 28 / 95 \\
08 / 01 / 95 \\
08 / 03 / 95 \\
09 / 14 / 95 \\
09 / 27 / 95\end{array}$ & \\
\hline
\end{tabular}


APPENDIX 3 
Appendix 3. Ground-water Levels from biweekly measurements of wells, Milford, New Hampshire

[ft, feet; ... no data; Meas.., measuring; Elev.., elevation]

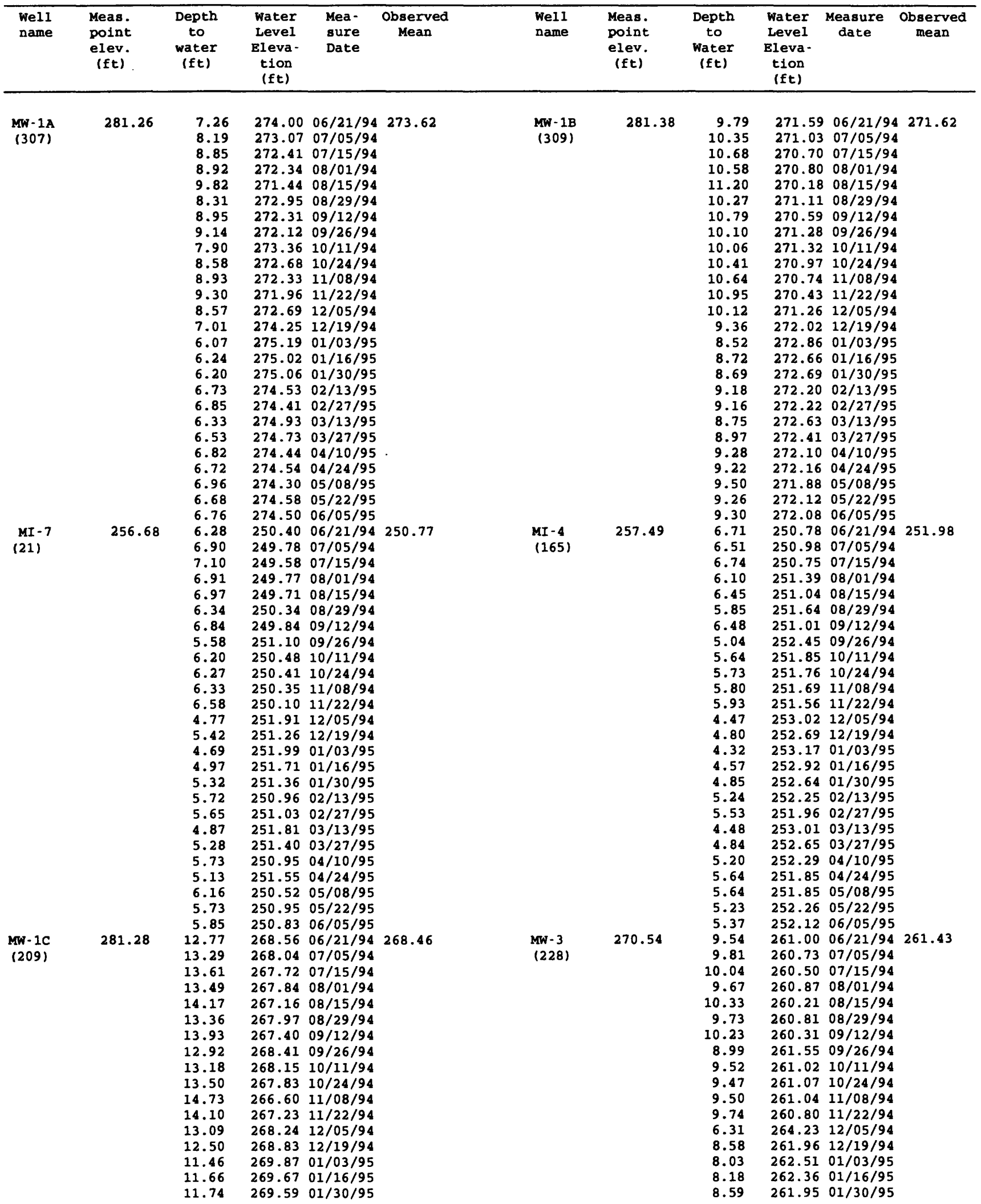


Appendix 3. Ground-water Levels from biweekly measurements of wells, Milford, New Hampshire--Continued

[ft, feet; ..., no data; Meas., measuring; Elev., elevation]

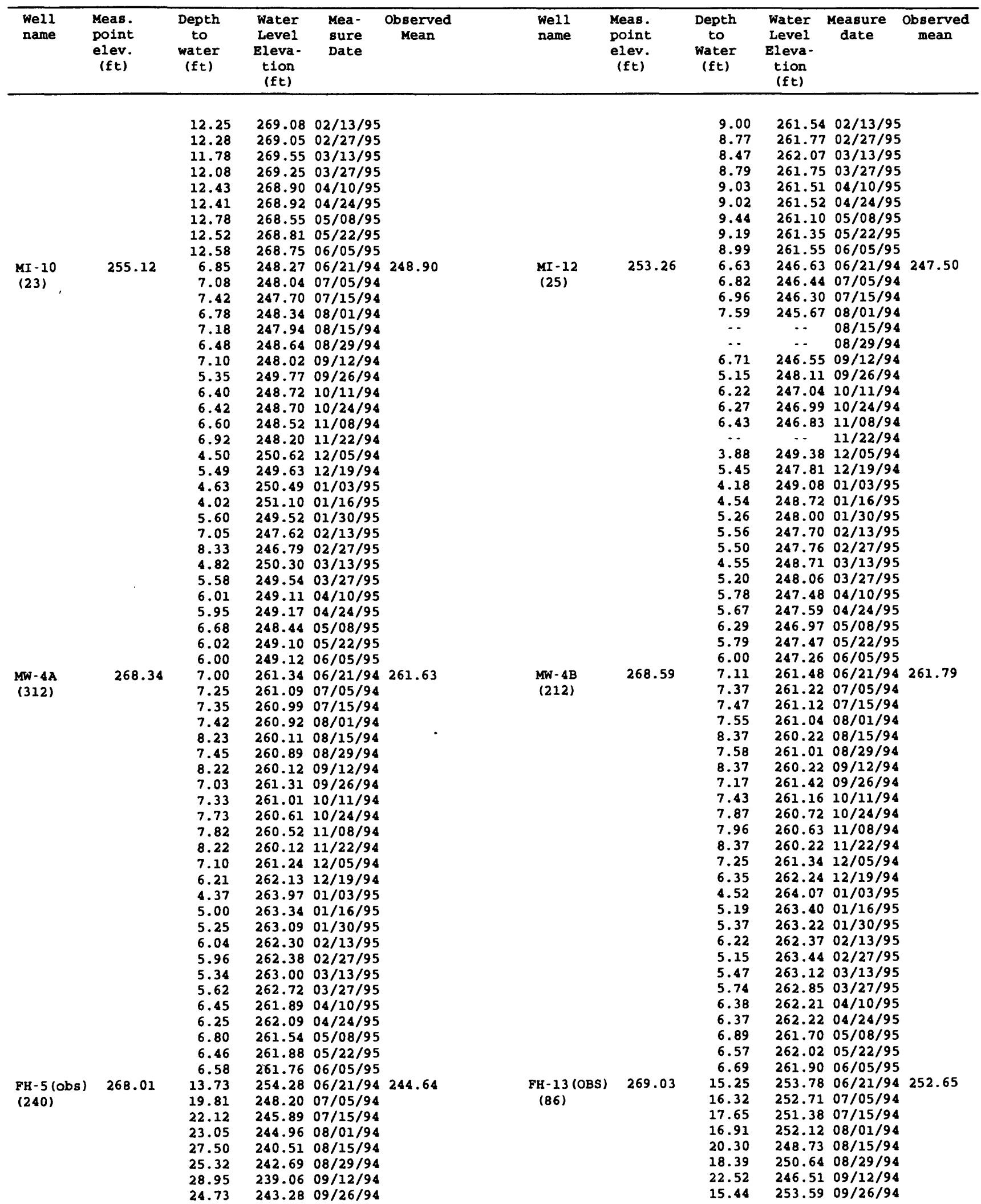


Appendix 3. Ground-water Levels from biweekly measurements of wells, Milford, New Hampshire--Continued [ft, feet; ..., no data; Meas.., measuring; Elev., elevation]

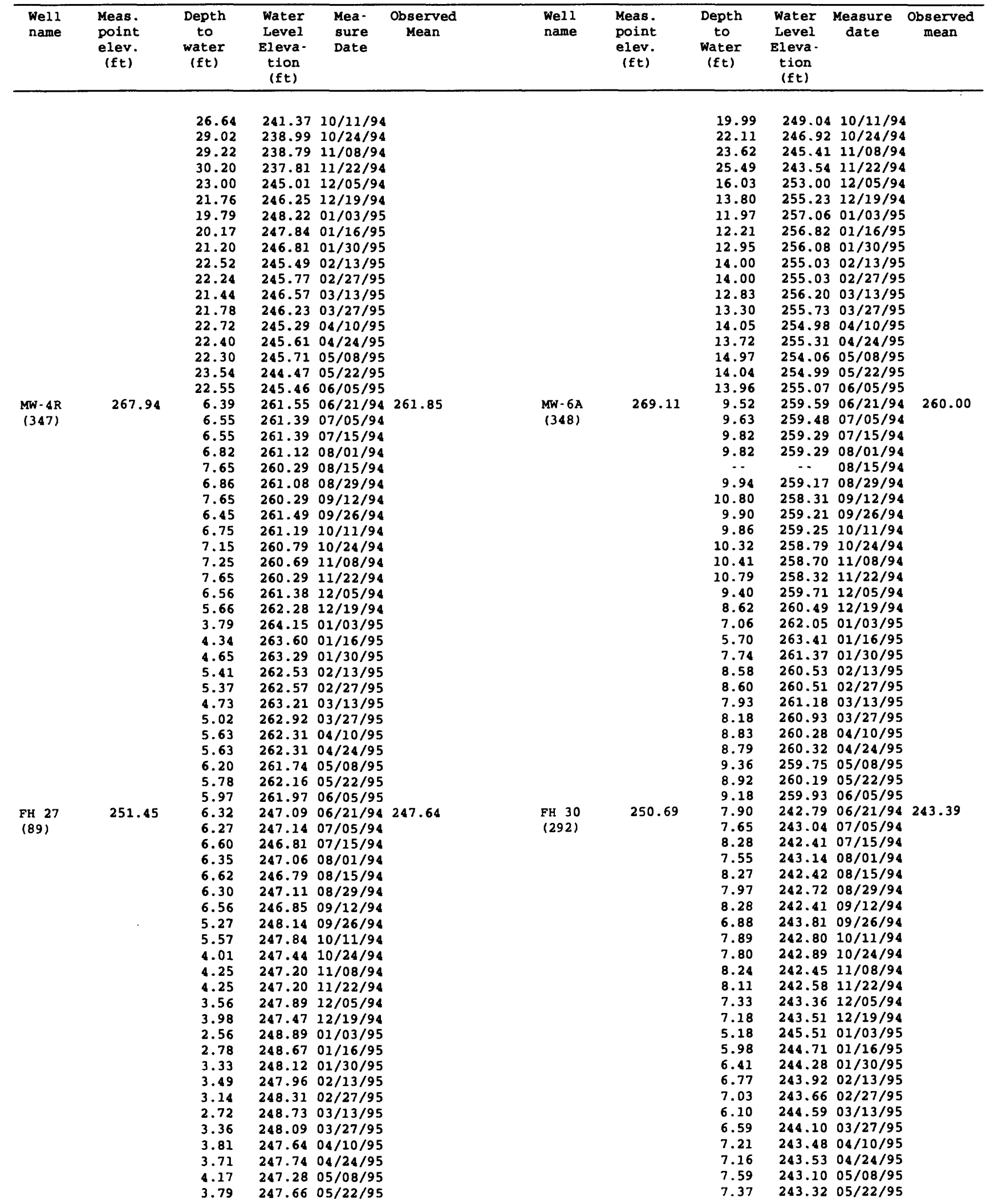


Appendix 3. Ground-water Levels from biweekly measurements of wells, Milford, New hampshire--Continued

[ft. feet; - - no data; Meas., measuring; Elev., elevation]

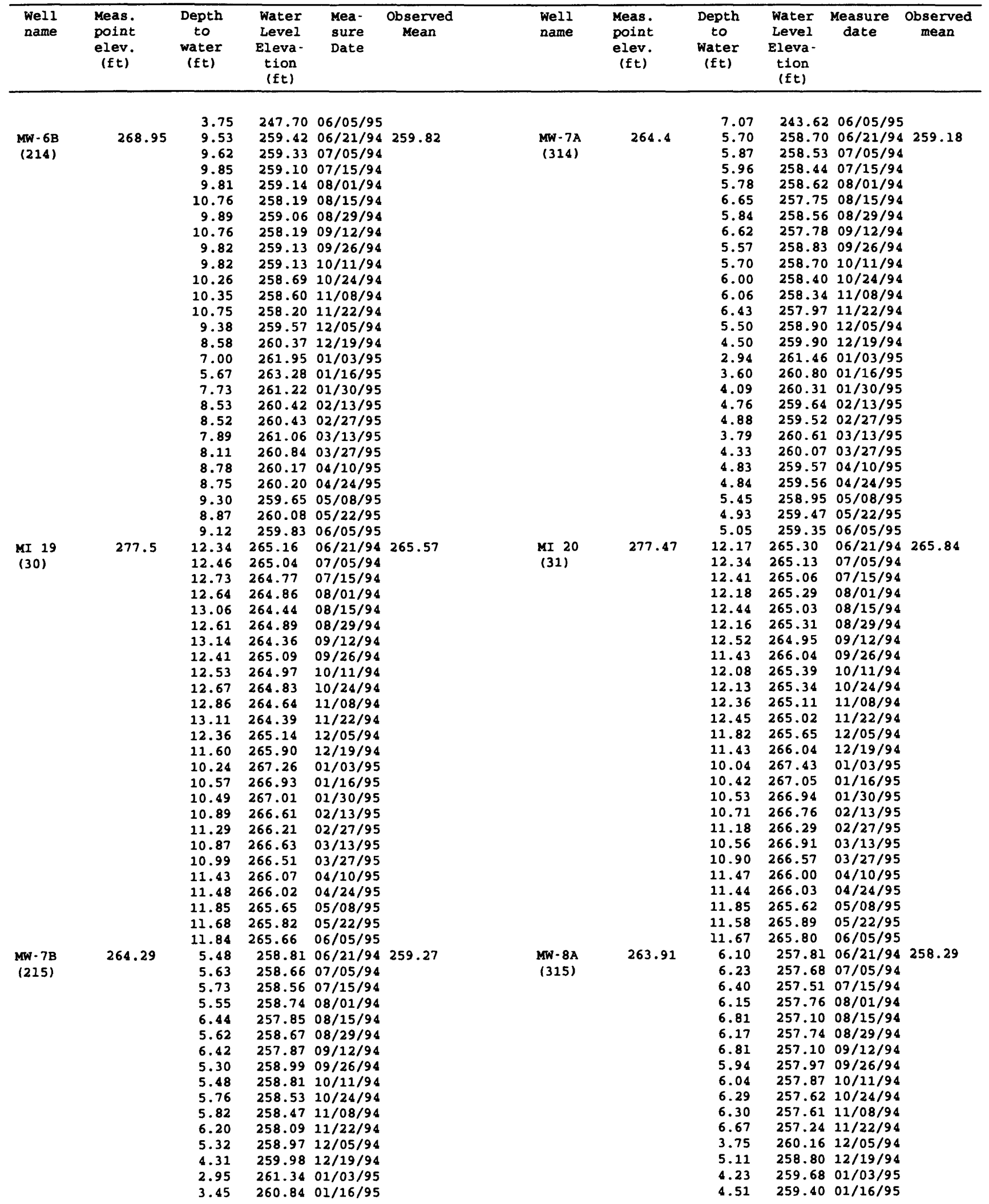


Appendix 3. Ground-water Levels from biweekly measurements of wells, Milford, New Hampshire--Continued

[ft, feet; ... no data; Meas., measuring; Elev., elevation]

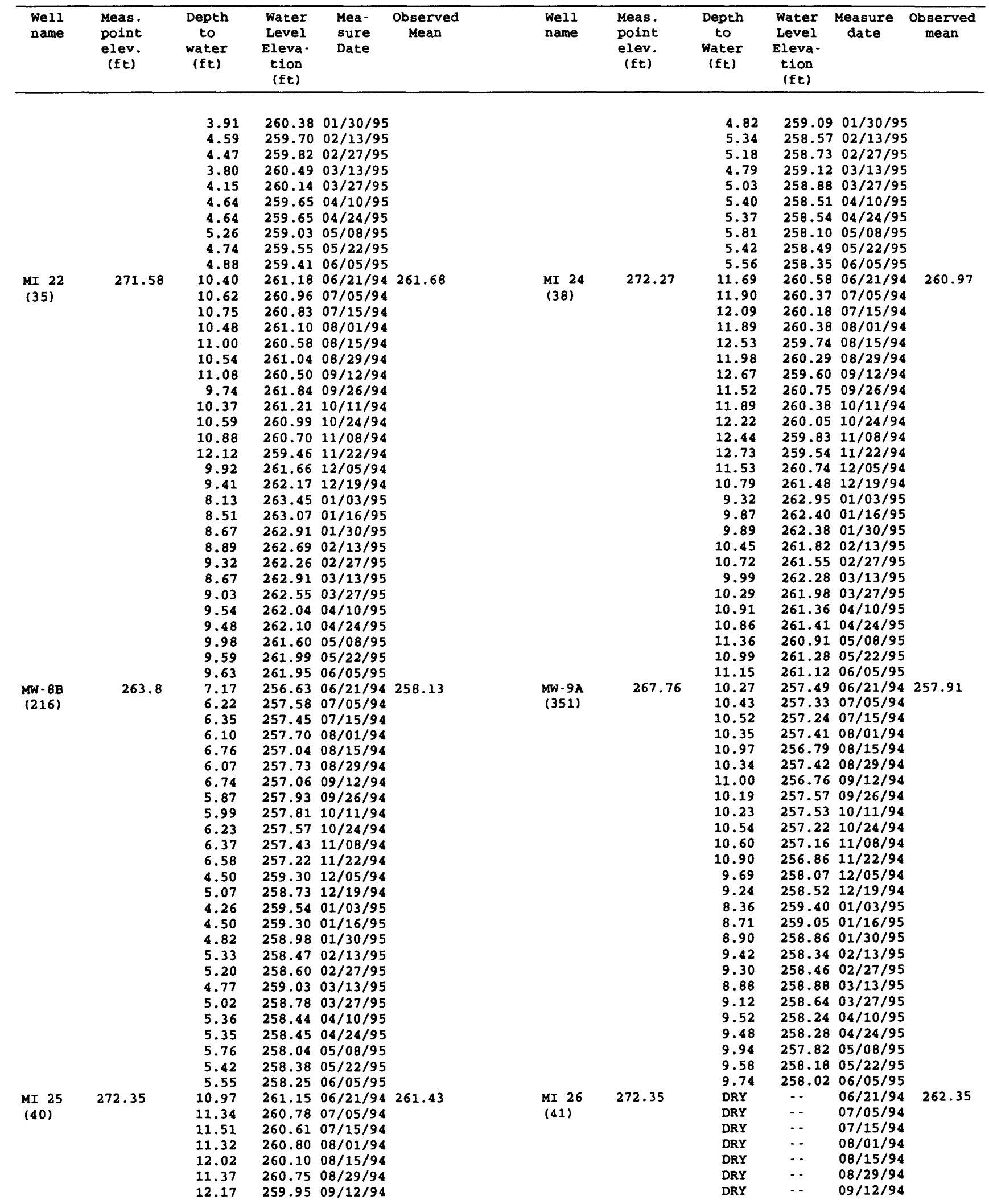


Appendix 3. Ground-water Levels from biweekly measurements of wells, Milford, New Hampshire--Continued

[ft, feet; ... no data; Meas... measuring; Elev., elevation]

\begin{tabular}{|c|c|c|c|c|c|c|c|c|c|c|c|}
\hline $\begin{array}{l}\text { We11 } \\
\text { name }\end{array}$ & $\begin{array}{l}\text { Meas. } \\
\text { point } \\
\text { elev. } \\
(f t)\end{array}$ & $\begin{array}{c}\text { Depth } \\
\text { to } \\
\text { water } \\
(f t)\end{array}$ & $\begin{array}{l}\text { Water } \\
\text { Leve1 } \\
\text { Eleva- } \\
\text { tion } \\
\text { (ft) }\end{array}$ & $\begin{array}{l}\text { Mea- } \\
\text { sure } \\
\text { Date }\end{array}$ & $\begin{array}{l}\text { Observed } \\
\text { Mean }\end{array}$ & $\begin{array}{l}\text { Wel1 } \\
\text { name }\end{array}$ & $\begin{array}{l}\text { Meas. } \\
\text { point } \\
\text { elev. } \\
(f t)\end{array}$ & $\begin{array}{c}\text { Depth } \\
\text { to } \\
\text { water } \\
(f t)\end{array}$ & $\begin{array}{l}\text { Water } \\
\text { Level } \\
\text { Eleva- } \\
\text { tion } \\
\text { (ft) }\end{array}$ & $\begin{array}{c}\text { Measure } \\
\text { date }\end{array}$ & $\begin{array}{c}\text { Observed } \\
\text { mean }\end{array}$ \\
\hline
\end{tabular}

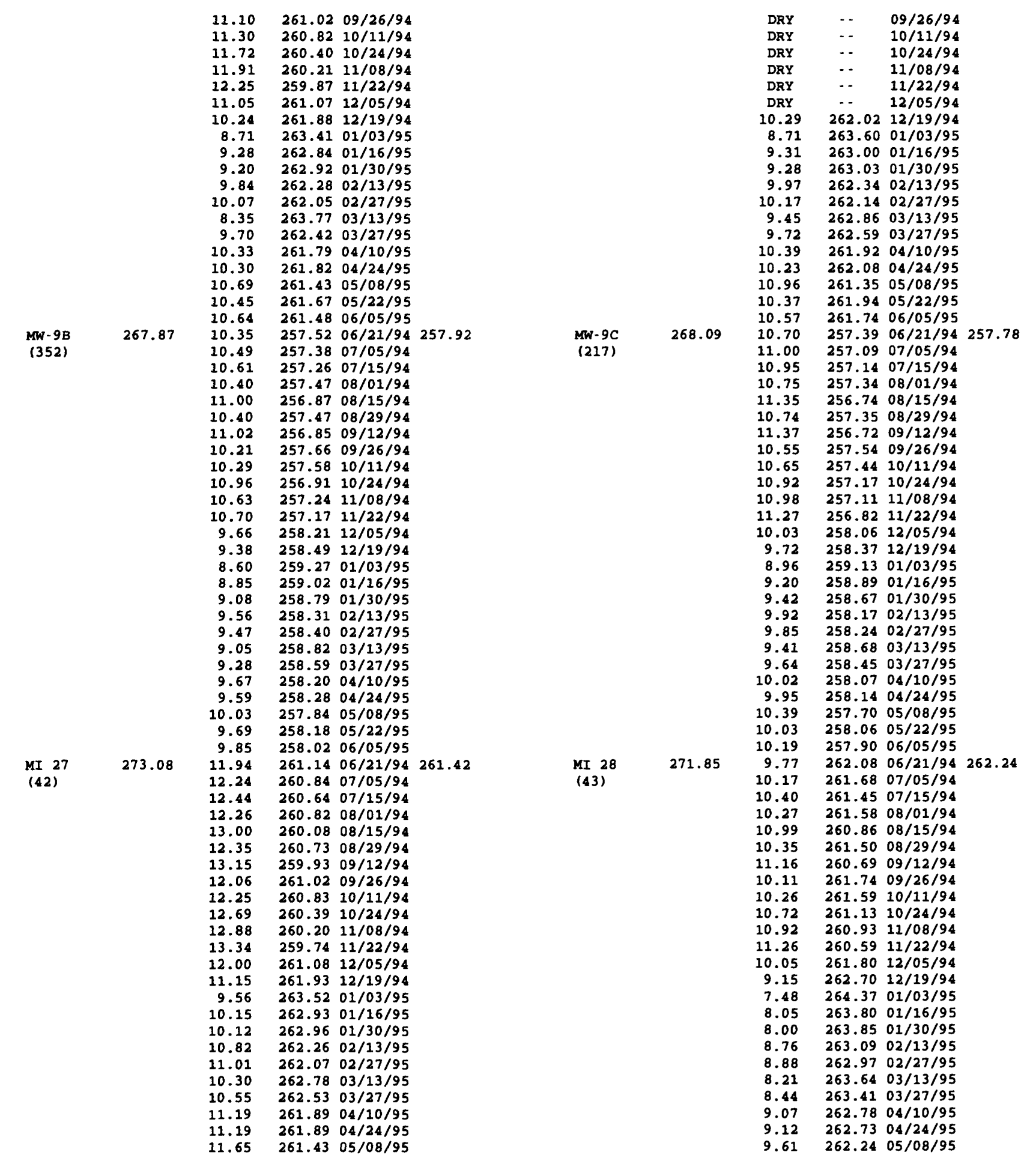


Appendix 3. Ground-water Levels from biweekly measurements of wells, Milford, New Hampshire--Continued

[ft, feet; --, no data; Meas.., measuring; Elev.., elevation]

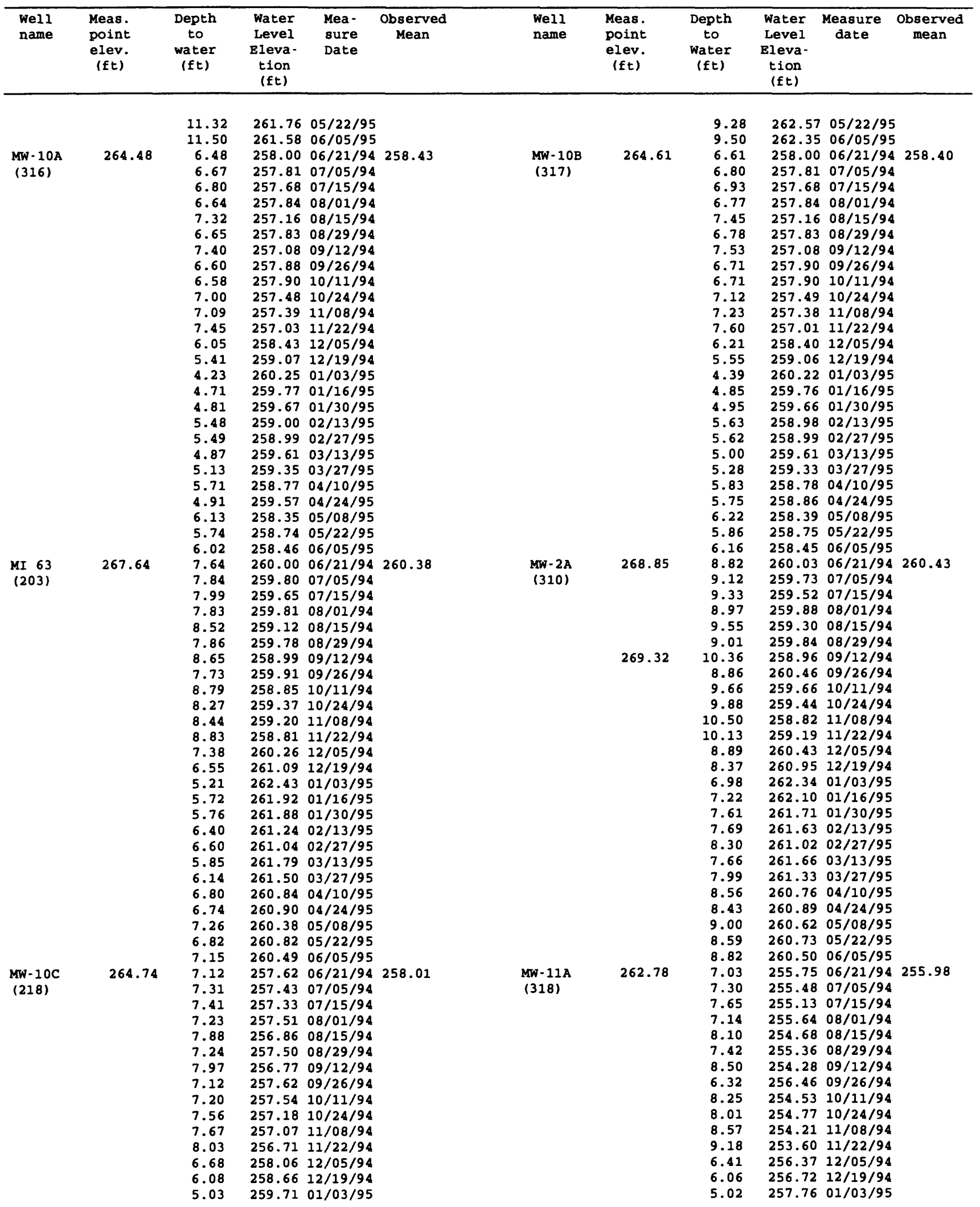


Appendix 3. Ground-water Levels from biweekly measurements of wells, Milford, New Hampshire--Continued

[ft, feet; .., no data; Meas.., measuring; Elev.., elevation]

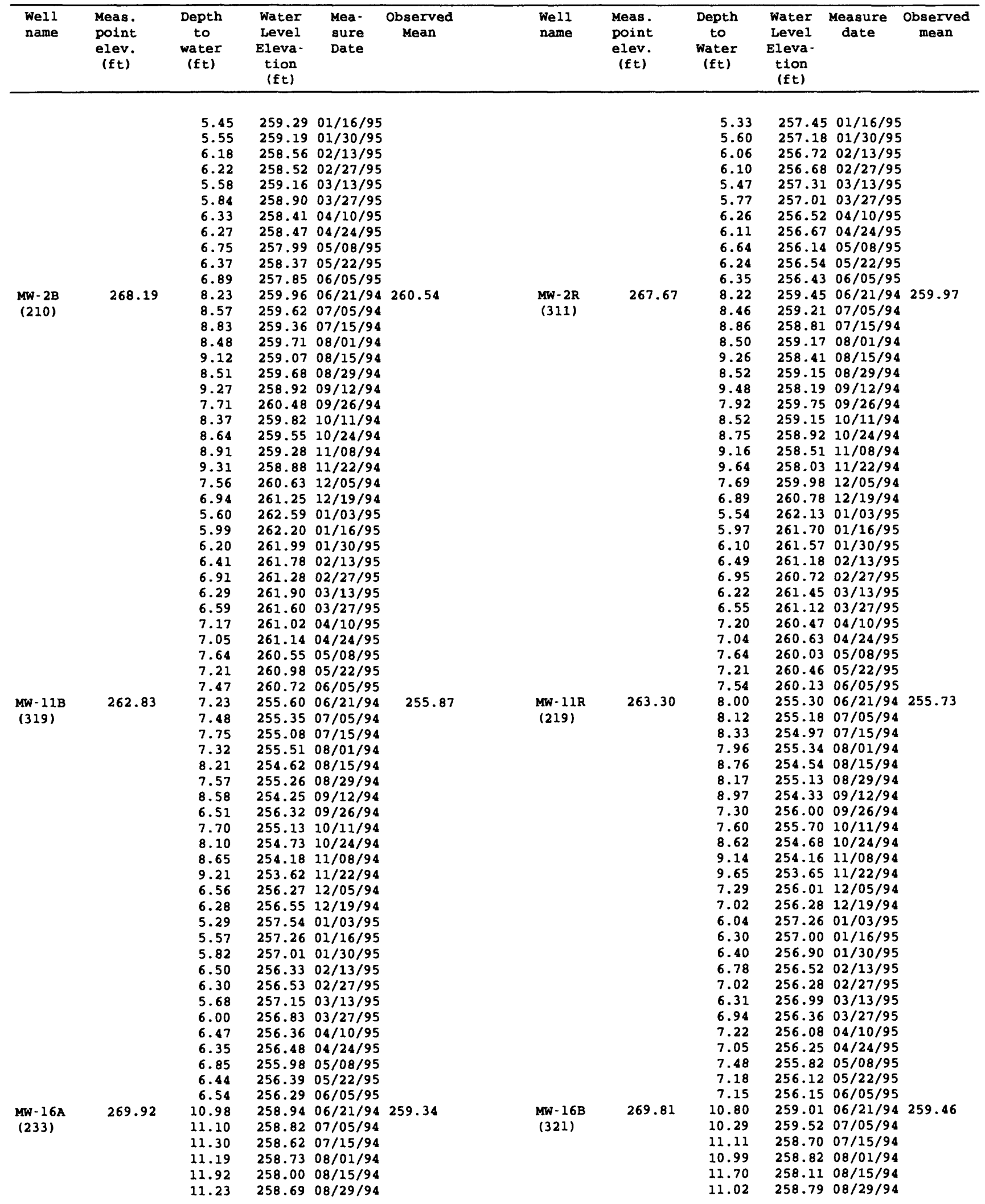


Appendix 3. Ground-water Levels from biweekly measurements of wells, Milford, New Hampshire--Continued [ft, feet; ..., no data; Meas.. measuring; Elev.. elevation]

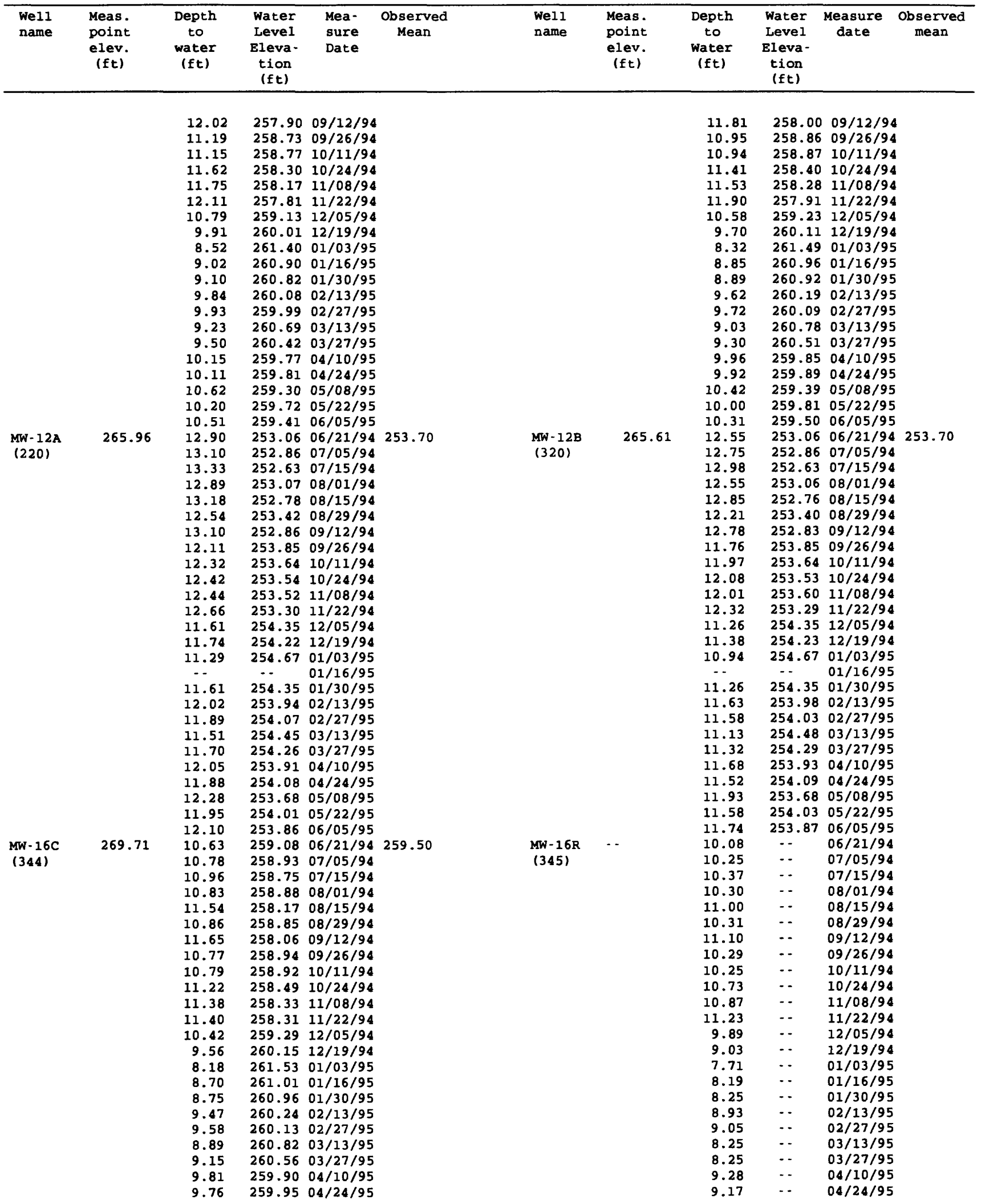


Appendix 3. Ground-water Levels from biweekly measurements of wells, Milford, New Hampshire--Continued

[ft, feet; ... no data; Meas., measuring; Elev., elevation]

\begin{tabular}{|c|c|c|c|c|c|c|c|c|c|c|c|}
\hline $\begin{array}{l}\text { Well } \\
\text { name }\end{array}$ & $\begin{array}{l}\text { Meas. } \\
\text { point } \\
\text { elev. } \\
\text { (ft) }\end{array}$ & $\begin{array}{c}\text { Depth } \\
\text { to } \\
\text { water } \\
\text { (ft) }\end{array}$ & $\begin{array}{l}\text { water } \\
\text { Level } \\
\text { Eleva- } \\
\text { tion } \\
\text { (ft) }\end{array}$ & $\begin{array}{l}\text { Mea- } \\
\text { sure } \\
\text { Date }\end{array}$ & $\begin{array}{l}\text { Observed } \\
\text { Mean }\end{array}$ & $\begin{array}{l}\text { We11 } \\
\text { name }\end{array}$ & $\begin{array}{l}\text { Meas. } \\
\text { point } \\
\text { elev. } \\
\text { (ft) }\end{array}$ & $\begin{array}{l}\text { Depth } \\
\text { to } \\
\text { water } \\
\text { (ft) }\end{array}$ & $\begin{array}{l}\text { Water } \\
\text { Level } \\
\text { Eleva- } \\
\text { tion } \\
\text { (ft) }\end{array}$ & $\begin{array}{l}\text { Measure } \\
\text { date }\end{array}$ & $\begin{array}{l}\text { Observed } \\
\text { mean }\end{array}$ \\
\hline
\end{tabular}

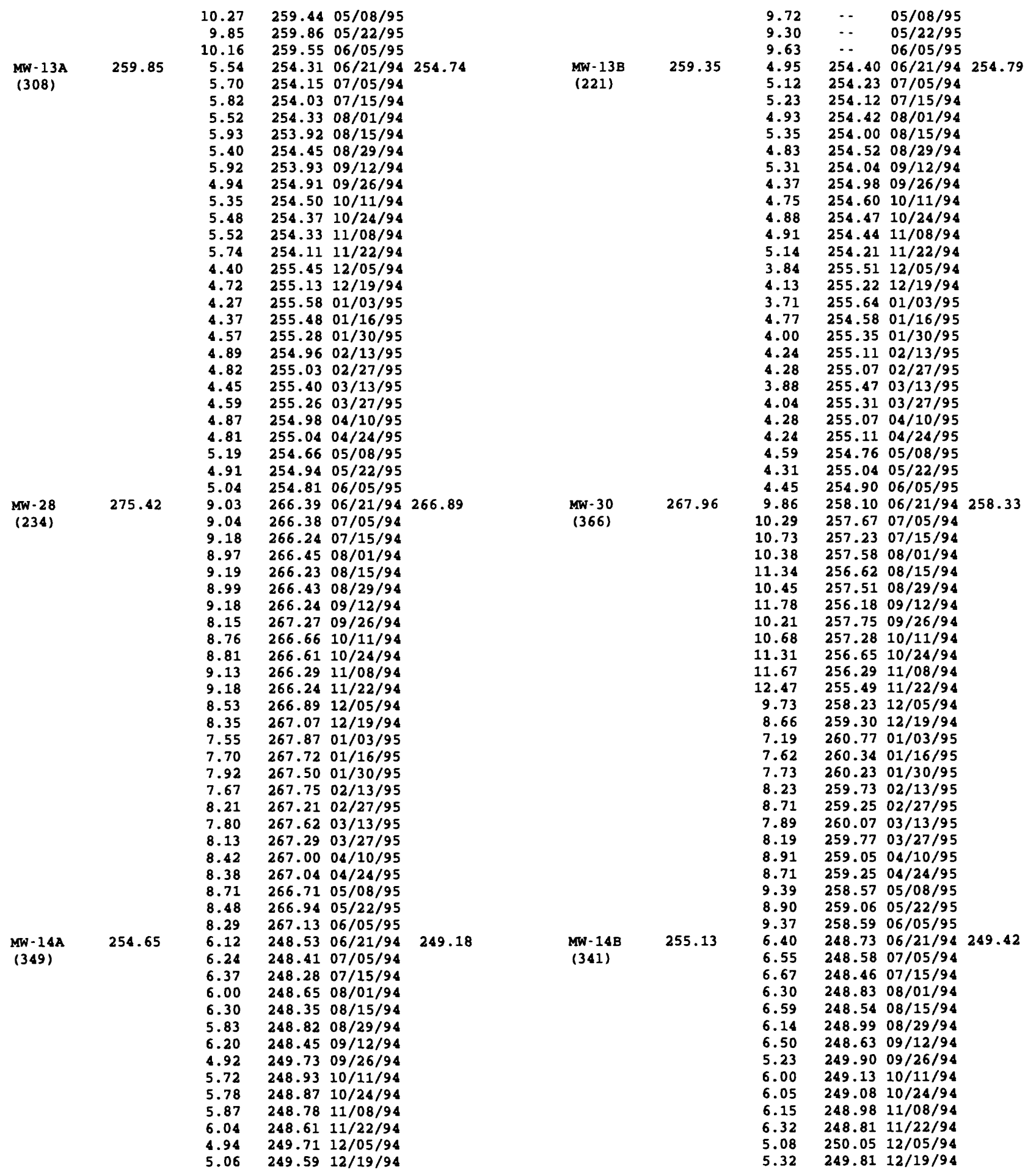


Appendix 3. Ground-water Levels from biweekly measurements of wells, Milford, New Hampshire--Continued

[ft, feet; ..., no data; Meas.., measuring; Elev., elevation]

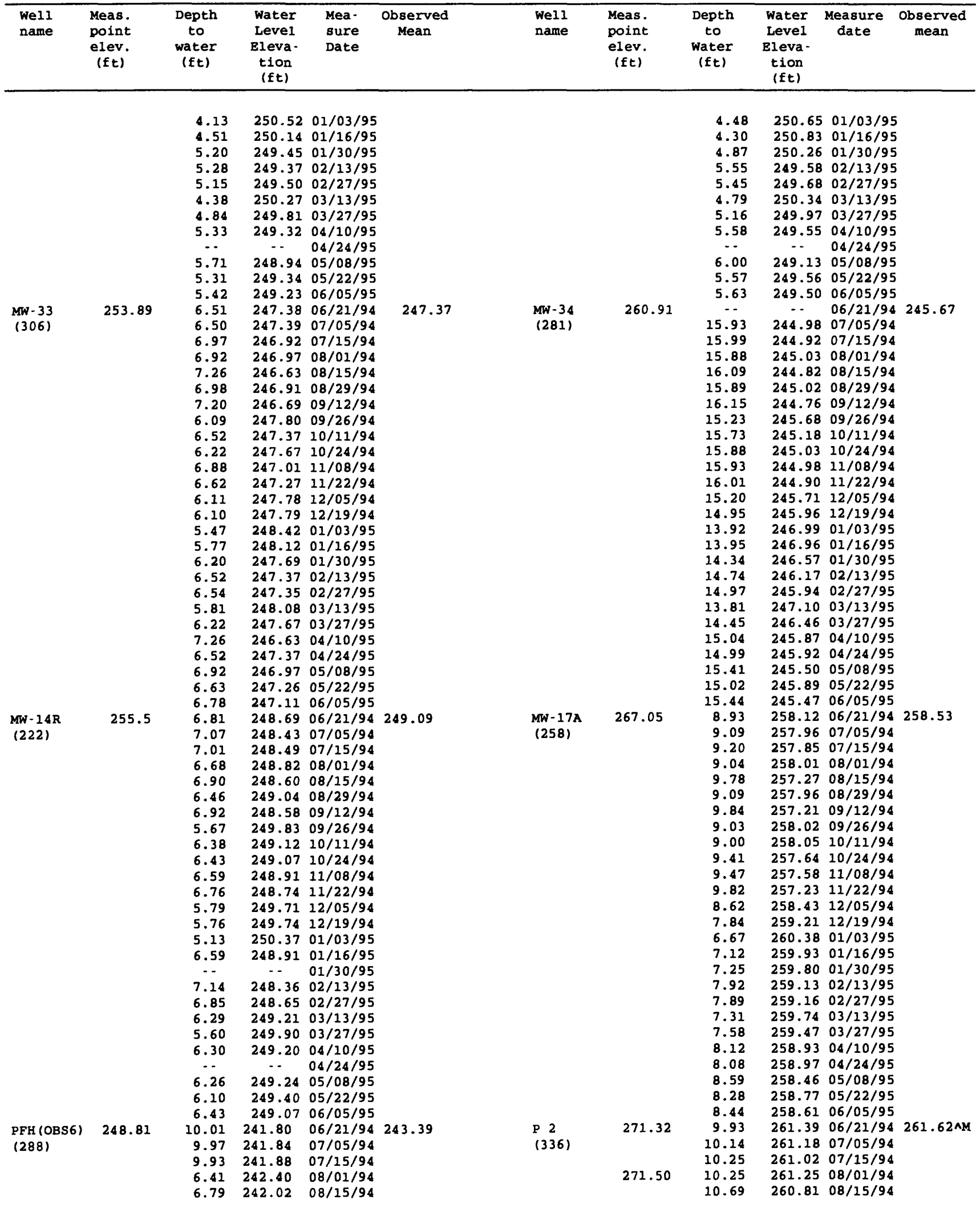


Appendix 3. Ground-water Levels from biweekly measurements of wells, Milford, New Hampshire--Continued

[ft, feet; ..., no data; Meas., measuring; Elev., elevation]

\begin{tabular}{|c|c|c|c|c|c|c|c|c|c|c|c|}
\hline $\begin{array}{l}\text { Wel1 } \\
\text { name }\end{array}$ & $\begin{array}{l}\text { Meas. } \\
\text { point } \\
\text { elev. } \\
\text { (ft) }\end{array}$ & $\begin{array}{l}\text { Depth } \\
\text { to } \\
\text { water } \\
\text { (ft) }\end{array}$ & $\begin{array}{l}\text { Water } \\
\text { Level } \\
\text { Eleva- } \\
\text { tion } \\
\text { (ft) }\end{array}$ & $\begin{array}{l}\text { Mea- } \\
\text { sure } \\
\text { Date }\end{array}$ & $\begin{array}{c}\text { Observed } \\
\text { Mean }\end{array}$ & $\begin{array}{l}\text { Well } \\
\text { name }\end{array}$ & $\begin{array}{l}\text { Meas. } \\
\text { point } \\
\text { elev. } \\
\text { (ft) }\end{array}$ & $\begin{array}{l}\text { Depth } \\
\text { to } \\
\text { water } \\
\text { (ft) }\end{array}$ & $\begin{array}{l}\text { Water } \\
\text { Level } \\
\text { Eleva- } \\
\text { tion } \\
\text { (ft) }\end{array}$ & $\begin{array}{l}\text { Measure } \\
\text { date }\end{array}$ & $\begin{array}{l}\text { Observed } \\
\text { mean }\end{array}$ \\
\hline & & $\begin{array}{l}6.56 \\
6.85 \\
5.69 \\
6.50 \\
5.87 \\
5.95 \\
5.89 \\
5.50 \\
5.56 \\
4.07 \\
4.00 \\
4.14 \\
4.16 \\
4.48 \\
4.01 \\
4.64 \\
4.54 \\
4.57 \\
4.48 \\
4.52 \\
4.82\end{array}$ & $\begin{array}{l}242.25 \\
241.96 \\
243.12 \\
242.31 \\
242.94 \\
242.86 \\
242.92 \\
243.31 \\
243.25 \\
244.74 \\
244.81 \\
244.67 \\
244.65 \\
244.33 \\
244.80 \\
244.17 \\
244.27 \\
244.24 \\
244.33 \\
244.292 \\
243.992\end{array}$ & $\begin{array}{l}08 / 29 / 94 \\
09 / 12 / 94 \\
09 / 26 / 94 \\
10 / 11 / 94 \\
10 / 24 / 94 \\
11 / 08 / 94 \\
11 / 22 / 94 \\
12 / 05 / 94 \\
12 / 19 / 94 \\
01 / 03 / 95 \\
01 / 16 / 95 \\
01 / 30 / 95 \\
02 / 13 / 95 \\
02 / 27 / 95 \\
03 / 13 / 95 \\
03 / 27 / 95 \\
04 / 10 / 95 \\
04 / 24 / 95 \\
05 / 08 / 95 \\
05 / 22 / 95 \\
06 / 05 / 95\end{array}$ & 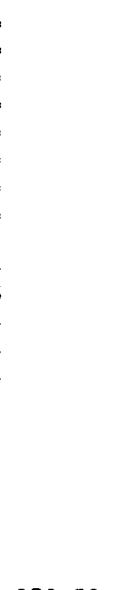 & & & $\begin{array}{r}10.53 \\
11.07 \\
9.62 \\
10.50 \\
10.60 \\
10.64 \\
10.55 \\
10.34 \\
10.35 \\
8.89 \\
9.41 \\
7.14 \\
7.22 \\
9.33 \\
8.46 \\
9.12 \\
9.60 \\
10.34 \\
10.56 \\
10.33 \\
10.45\end{array}$ & $\begin{array}{l}260.97 \\
260.43 \\
261.88 \\
261.00 \\
260.90 \\
260.86 \\
260.95 \\
261.16 \\
261.15 \\
262.61 \\
262.09 \\
264.36 \\
264.28 \\
262.17 \\
263.04 \\
262.38 \\
261.90 \\
261.16 \\
260.94 \\
261.17 \\
261.05\end{array}$ & 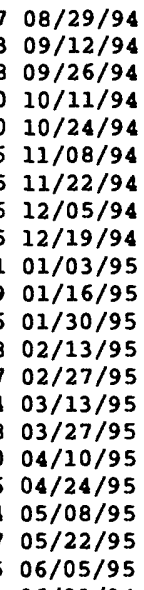 & \\
\hline $\begin{array}{c}M W-17 B \\
(322)\end{array}$ & 267.06 & $\begin{array}{l}8.94 \\
9.10 \\
9.21 \\
9.07 \\
9.79 \\
9.10 \\
9.85 \\
9.03 \\
9.01 \\
9.42 \\
9.49 \\
9.85 \\
8.62 \\
7.85 \\
6.67 \\
7.14 \\
7.25 \\
7.93 \\
7.91 \\
7.33 \\
7.58 \\
8.15 \\
8.08 \\
8.69 \\
8.19 \\
8.45\end{array}$ & $\begin{array}{l}258.12 \\
257.96 \\
257.85 \\
257.99 \\
257.27 \\
257.96 \\
257.21 \\
258.03 \\
258.05 \\
257.64 \\
257.57 \\
257.21 \\
258.44 \\
259.21 \\
260.39 \\
259.92 \\
259.81 \\
259.13 \\
259.15 \\
259.73 \\
259.48 \\
258.91 \\
258.98 \\
258.37 \\
258.87 \\
258.61\end{array}$ & $\begin{array}{l}06 / 21 / 94 \\
07 / 05 / 94 \\
07 / 15 / 94 \\
08 / 01 / 94 \\
08 / 15 / 94 \\
08 / 29 / 94 \\
09 / 12 / 94 \\
09 / 26 / 94 \\
10 / 11 / 94 \\
10 / 24 / 94 \\
11 / 08 / 94 \\
11 / 22 / 94 \\
12 / 05 / 94 \\
12 / 19 / 94 \\
01 / 03 / 95 \\
01 / 16 / 95 \\
01 / 30 / 95 \\
02 / 13 / 95 \\
02 / 27 / 95 \\
03 / 13 / 95 \\
03 / 27 / 95 \\
04 / 10 / 95 \\
04 / 24 / 95 \\
05 / 08 / 95 \\
05 / 22 / 95 \\
06 / 05 / 95\end{array}$ & 258.53 & $\begin{array}{c}\text { MW-17C } \\
(323)\end{array}$ & 列 & $\begin{array}{r}9.25 \\
9.40 \\
9.53 \\
9.39 \\
10.07 \\
9.39 \\
10.15 \\
9.33 \\
9.32 \\
9.73 \\
9.80 \\
10.16 \\
8.86 \\
8.15 \\
7.00 \\
7.45 \\
7.57 \\
8.23 \\
8.21 \\
7.64 \\
7.89 \\
8.43 \\
8.38 \\
8.89 \\
8.48 \\
8.73\end{array}$ & $\begin{array}{l}258.03 \\
257.88 \\
257.75 \\
257.89 \\
257.21 \\
257.89 \\
257.13 \\
257.95 \\
257.96 \\
257.55 \\
257.48 \\
257.12 \\
258.42 \\
259.13 \\
260.28 \\
259.83 \\
259.71 \\
259.05 \\
259.07 \\
259.64 \\
259.39 \\
258.85 \\
258.90 \\
258.39 \\
258.80 \\
258.55\end{array}$ & $\begin{array}{l}06 / 21 / 94 \\
07 / 05 / 94 \\
07 / 15 / 94 \\
08 / 01 / 94 \\
08 / 15 / 94 \\
08 / 29 / 94 \\
09 / 12 / 94 \\
09 / 26 / 94 \\
10 / 11 / 94 \\
10 / 24 / 94 \\
11 / 08 / 94 \\
11 / 22 / 94 \\
12 / 05 / 94 \\
12 / 19 / 94 \\
01 / 03 / 95 \\
01 / 16 / 95 \\
01 / 30 / 95 \\
02 / 13 / 95 \\
02 / 27 / 95 \\
03 / 13 / 95 \\
03 / 27 / 95 \\
04 / 10 / 95 \\
04 / 24 / 95 \\
05 / 08 / 95 \\
05 / 22 / 95 \\
06 / 05 / 95\end{array}$ & 258.46 \\
\hline $\begin{array}{l}\text { P } 16 \\
(280)\end{array}$ & 260.43 & $\begin{array}{c}\text { DRY } \\
\text { DRY } \\
\text { DRY } \\
\text { DRY } \\
\text { DRY } \\
\text { DRY } \\
\text { DRY } \\
\text { DRY } \\
\text { DRY } \\
\text { DRY } \\
\text { DRY } \\
\text { DRY } \\
\text { DRY } \\
14.51 \\
13.48 \\
13.51 \\
13.90 \\
14.29 \\
14.54 \\
13.37 \\
14.01 \\
14.62\end{array}$ & 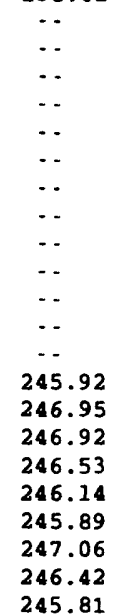 & $\begin{array}{l}06 / 21 / 94 \\
07 / 05 / 94 \\
07 / 15 / 94 \\
08 / 01 / 94 \\
08 / 15 / 94 \\
08 / 29 / 94 \\
09 / 12 / 94 \\
09 / 26 / 94 \\
10 / 11 / 94 \\
10 / 24 / 94 \\
11 / 08 / 94 \\
11 / 22 / 94 \\
12 / 05 / 94 \\
12 / 19 / 94 \\
01 / 03 / 95 \\
01 / 16 / 95 \\
01 / 30 / 95 \\
02 / 13 / 95 \\
02 / 27 / 95 \\
03 / 13 / 95 \\
03 / 27 / 95 \\
04 / 10 / 95\end{array}$ & 246.31 & $\begin{array}{l}\text { SPZ 1 } \\
(250)\end{array}$ & 259.17 & $\begin{array}{l}5.68 \\
5.89 \\
6.27 \\
6.13 \\
6.85 \\
6.50 \\
7.20 \\
6.16 \\
6.85 \\
6.94 \\
7.24 \\
7.55 \\
6.59 \\
7.88 \\
3.91 \\
3.64 \\
4.15 \\
4.94 \\
4.88 \\
4.25 \\
4.49 \\
5.16\end{array}$ & $\begin{array}{l}253.49 \\
253.28 \\
252.90 \\
253.04 \\
252.32 \\
252.67 \\
251.97 \\
253.01 \\
252.32 \\
252.23 \\
251.93 \\
251.62 \\
252.58 \\
251.29 \\
255.26 \\
255.53 \\
255.02 \\
254.23 \\
254.29 \\
254.92 \\
254.68 \\
254.01\end{array}$ & $\begin{array}{l}06 / 21 / 94 \\
07 / 05 / 94 \\
07 / 15 / 94 \\
08 / 01 / 94 \\
08 / 15 / 94 \\
08 / 29 / 94 \\
09 / 12 / 94 \\
09 / 26 / 94 \\
10 / 11 / 94 \\
10 / 24 / 94 \\
11 / 08 / 94 \\
11 / 22 / 94 \\
12 / 05 / 94 \\
12 / 19 / 94 \\
01 / 03 / 95 \\
01 / 16 / 95 \\
01 / 30 / 95 \\
02 / 13 / 95 \\
02 / 27 / 95 \\
03 / 13 / 95 \\
03 / 27 / 95 \\
04 / 10 / 95\end{array}$ & 253.35 \\
\hline
\end{tabular}


Appendix 3. Ground-water Levels from biweekly measurements of wells, Milford, New Hampshire--Continued

[Et, feet; ..., no data; Meas.., measuring; Elev., elevation]

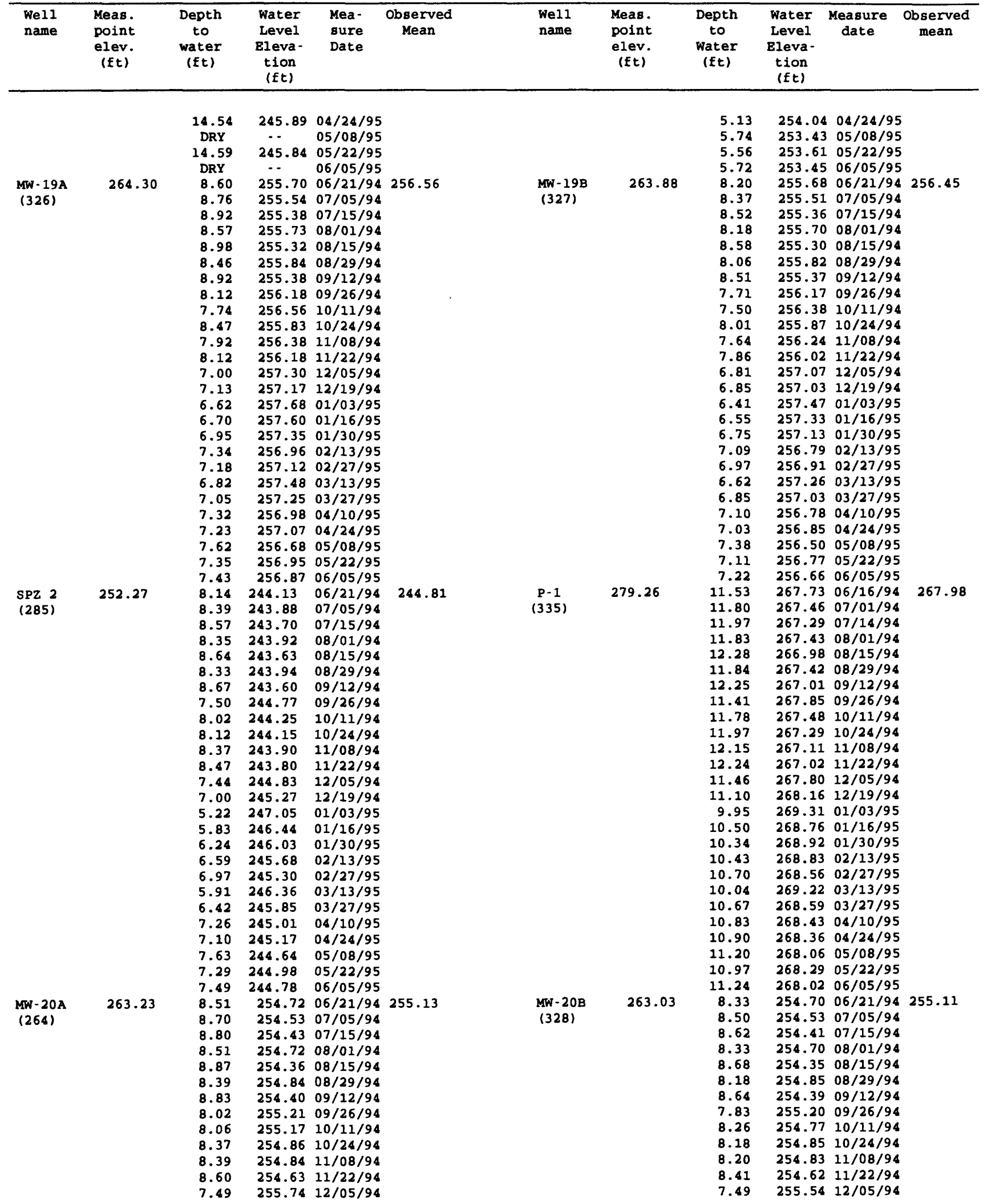


Appendix 3. Ground-water Levels from biweekly measurements of wells, Milford, New Hampshire--Continued

[ft, feet; -., no data; Meas., measuring; Elev.., elevation]

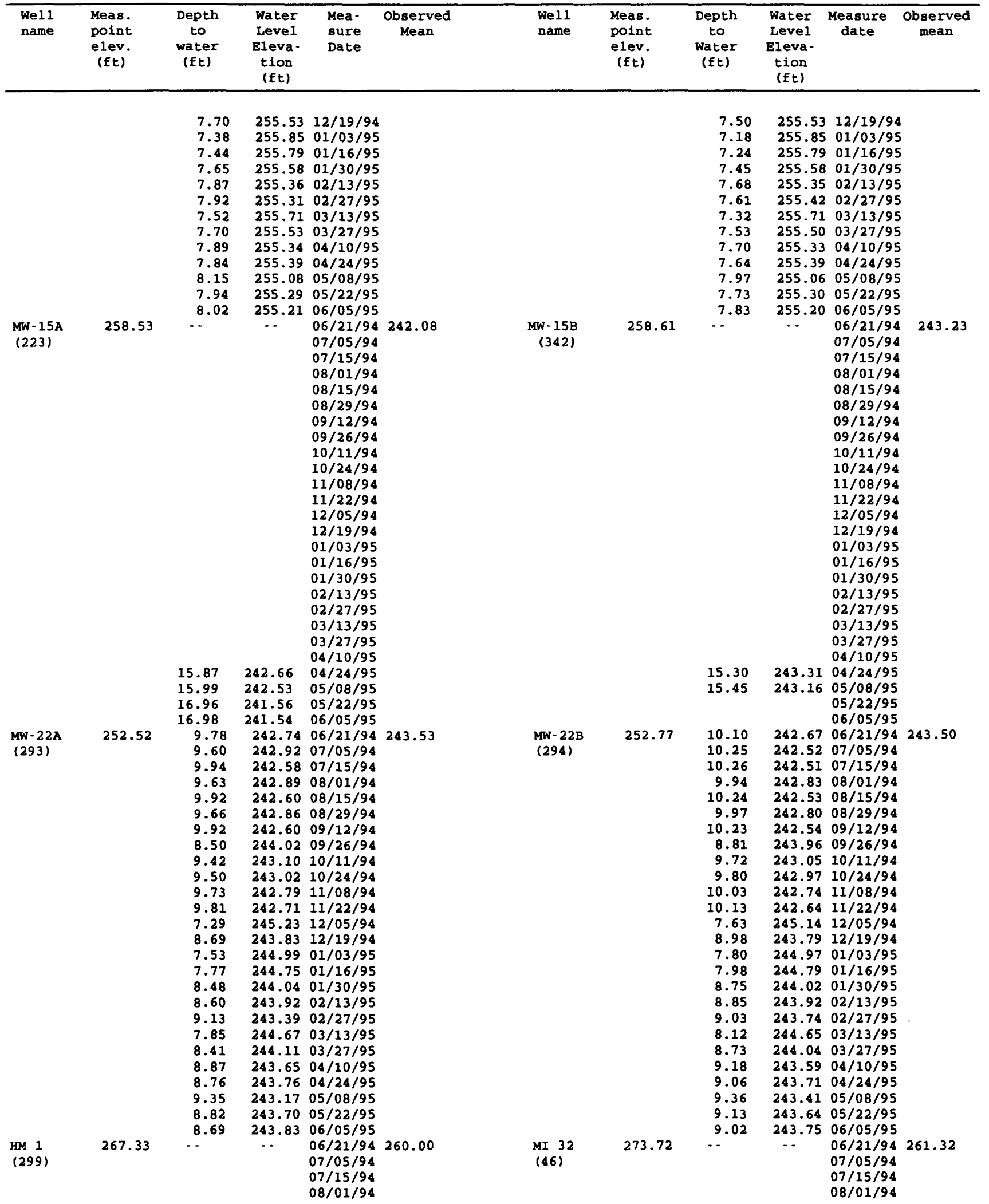


Appendix 3. Ground-water Levels from biweekly measurements of wells, Milford, New Hampshire--Continued

[ft, feet; ..., no data; Meas., measuring; Elev.., elevation]

\begin{tabular}{|c|c|c|c|c|c|c|c|c|c|c|c|}
\hline $\begin{array}{l}\text { Wel1 } \\
\text { name }\end{array}$ & $\begin{array}{l}\text { Meas. } \\
\text { point } \\
\text { elev. } \\
\text { (ft) }\end{array}$ & $\begin{array}{l}\text { Depth } \\
\text { to } \\
\text { water } \\
\text { (ft) }\end{array}$ & $\begin{array}{c}\text { Water } \\
\text { Level } \\
\text { Eleva- } \\
\text { tion } \\
\text { (tt) }\end{array}$ & $\begin{array}{l}\text { Mea- } \\
\text { sure } \\
\text { Date }\end{array}$ & $\begin{array}{l}\text { Observed } \\
\text { Mean }\end{array}$ & $\begin{array}{l}\text { Well } \\
\text { name }\end{array}$ & $\begin{array}{c}\text { Meas. } \\
\text { point } \\
\text { elev. } \\
(f t)\end{array}$ & $\begin{array}{l}\text { Depth } \\
\text { to } \\
\text { water } \\
\text { (ft) }\end{array}$ & $\begin{array}{c}\text { Water } \\
\text { Level } \\
\text { Eleva- } \\
\text { tion } \\
\text { (ft) }\end{array}$ & $\begin{array}{l}\text { Measure } \\
\text { date }\end{array}$ & $\begin{array}{l}\text { Observed } \\
\text { mean }\end{array}$ \\
\hline
\end{tabular}

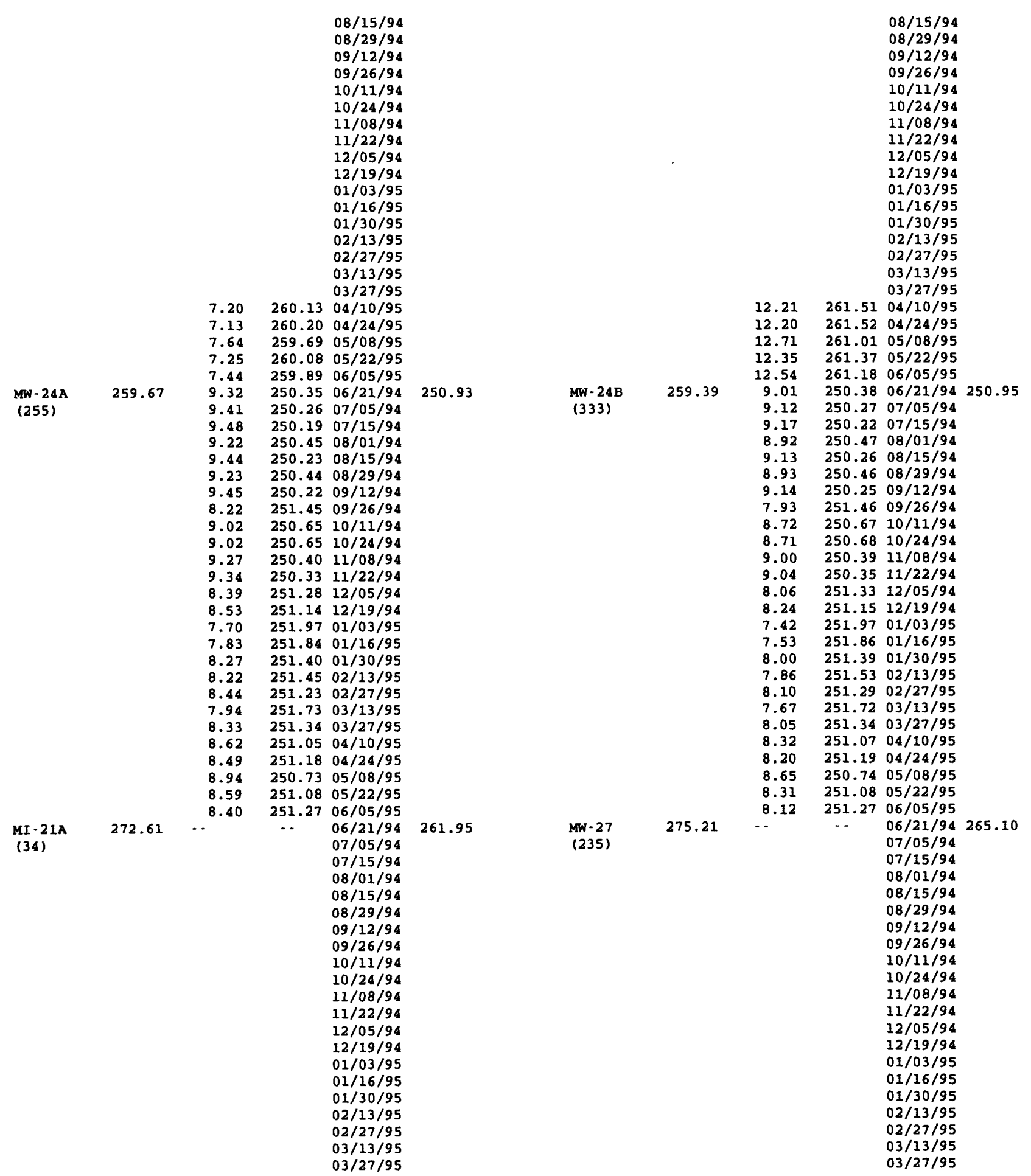


Appendix 3. Ground-water Levels from biweekly measurements of wells, Milford, New Hampshire--Continued [ft, feet; ..., no data; Meas., measuring; Elev.., elevation]

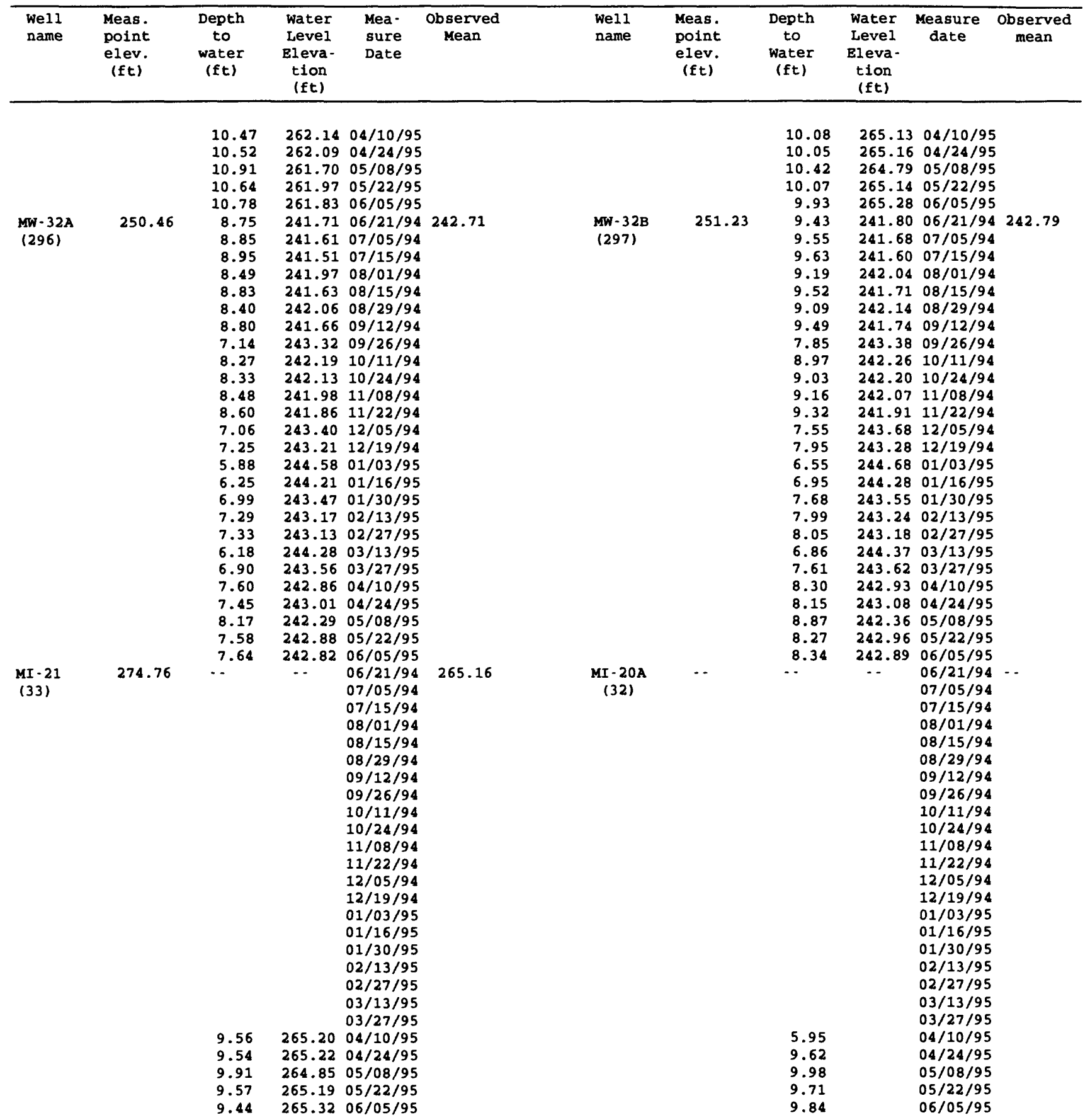


APPENDIX 4 


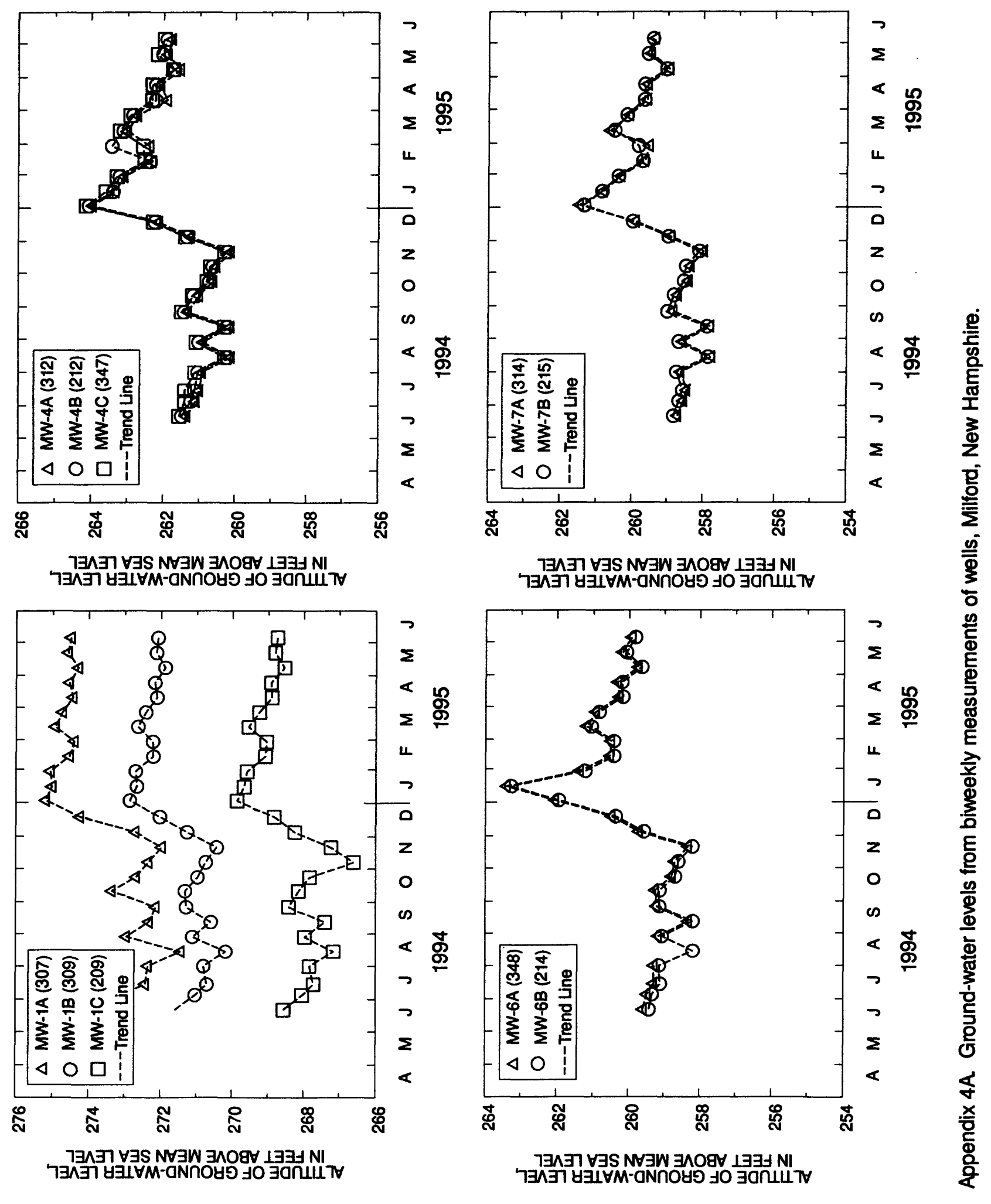



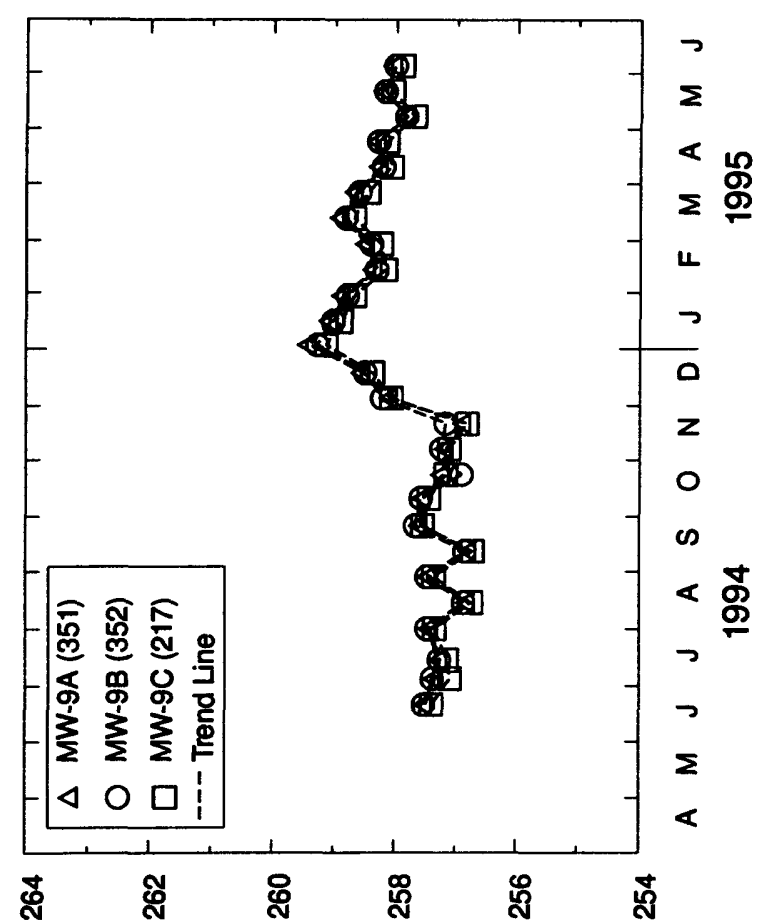

7스보 N N ว
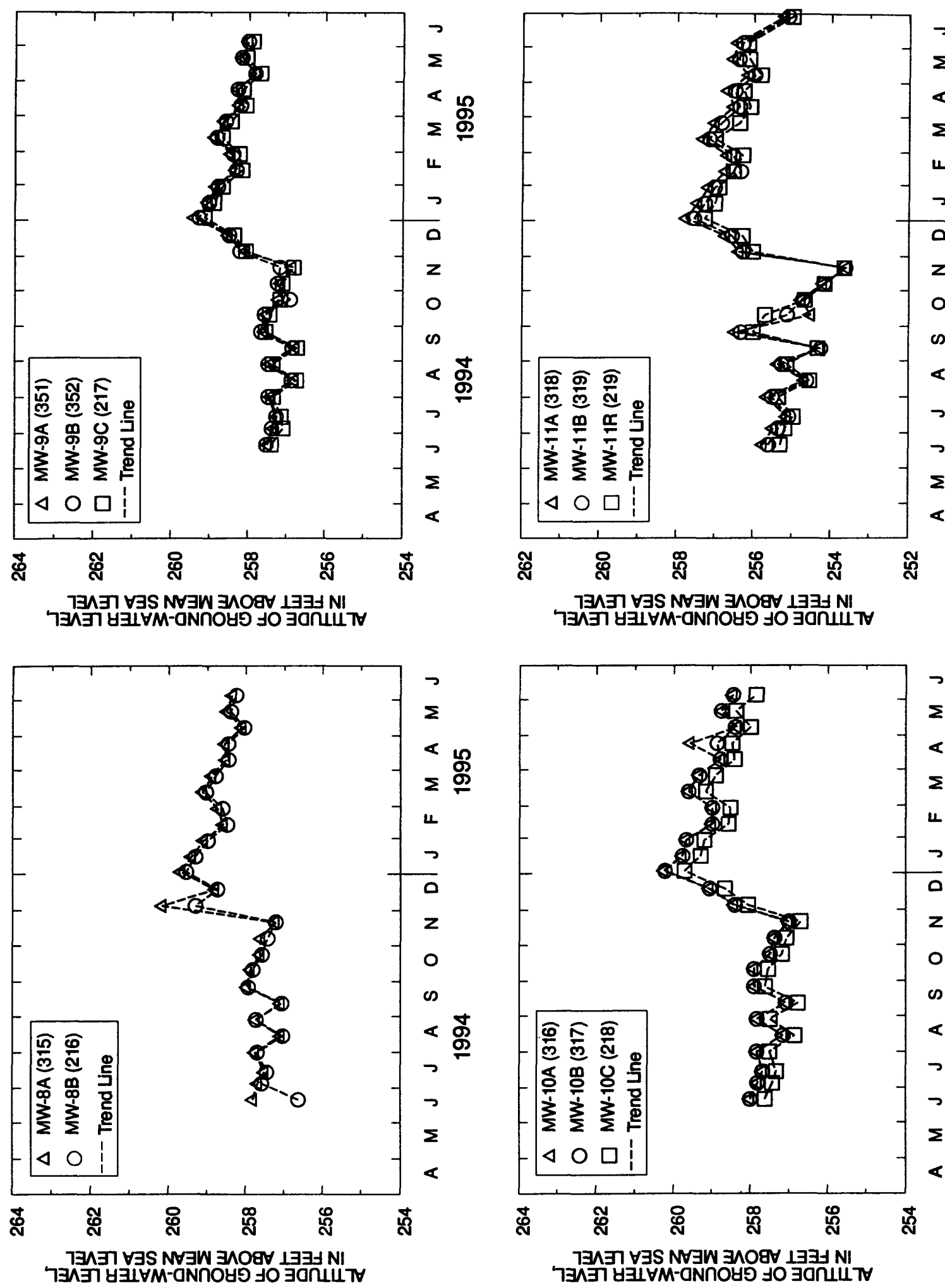

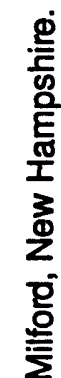

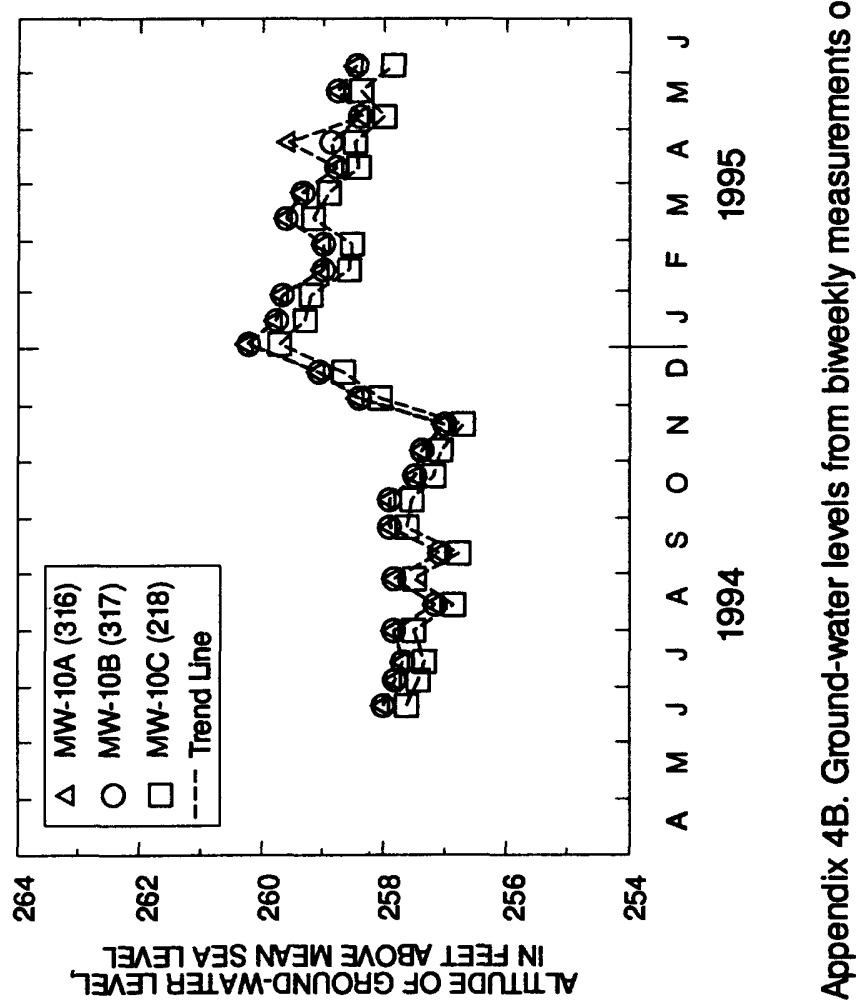



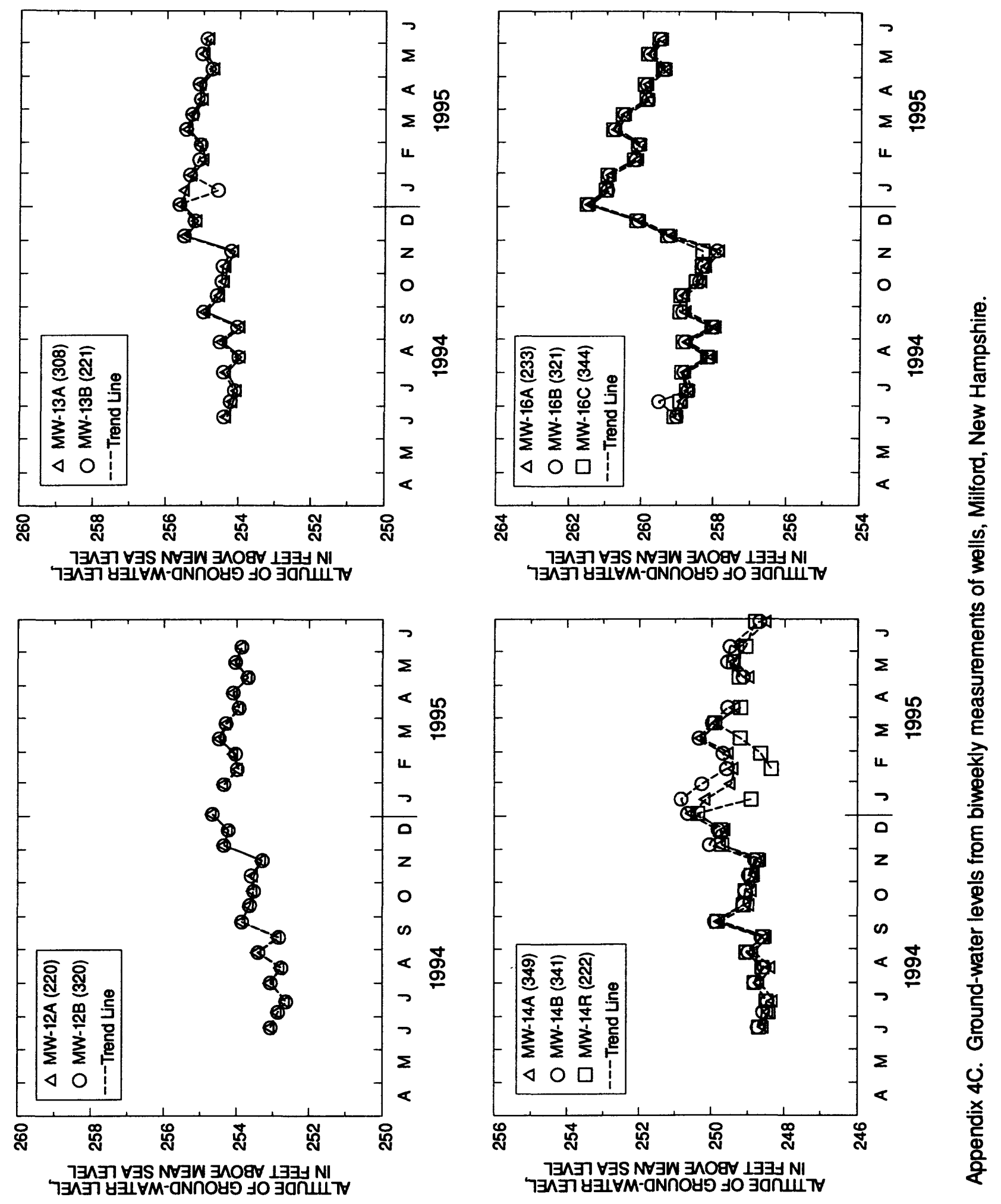


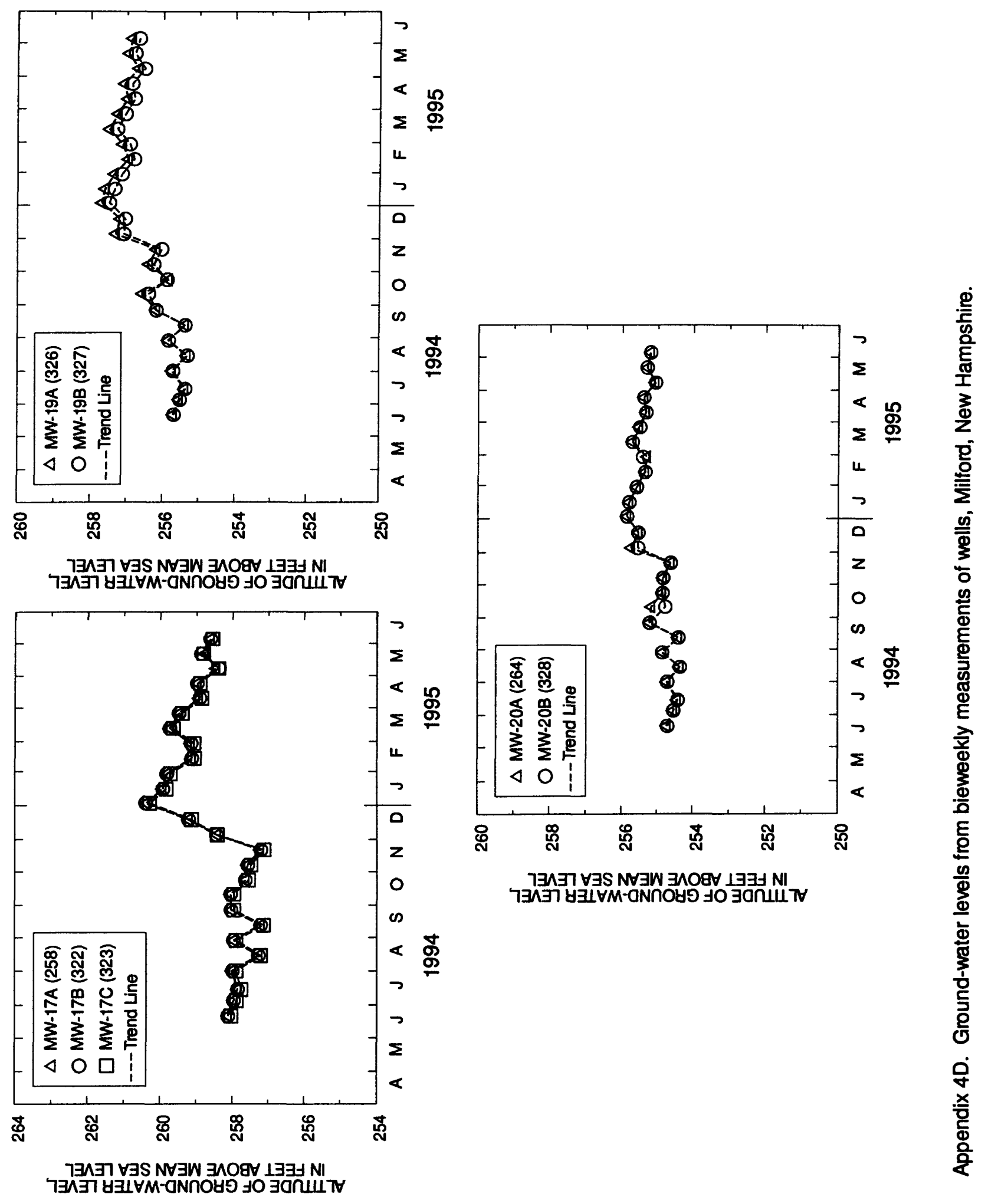




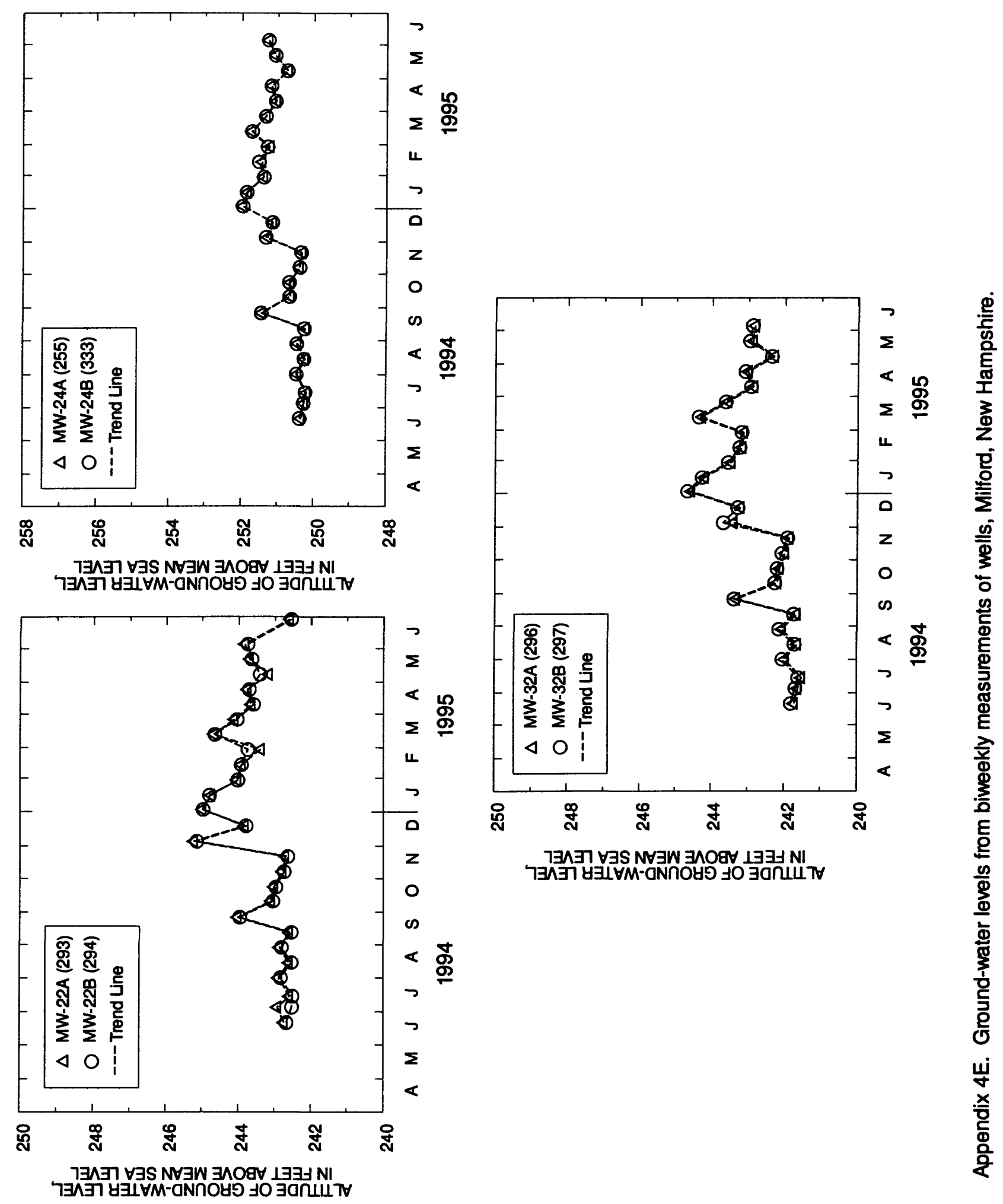



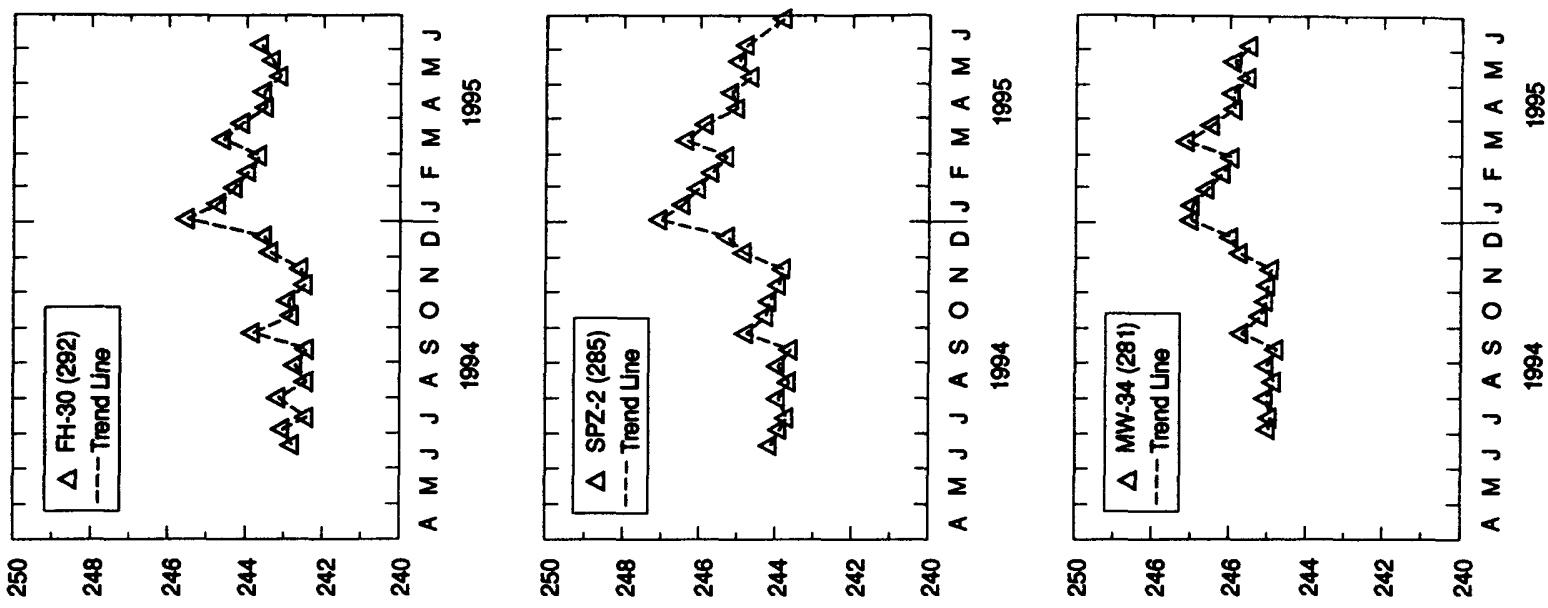

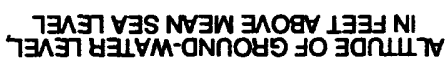

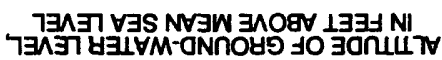

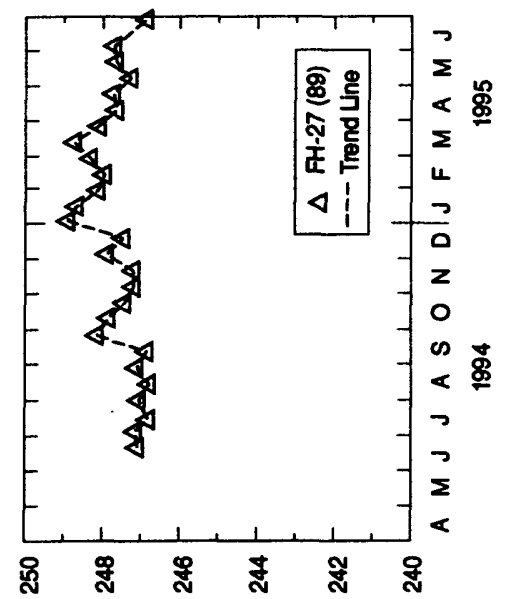

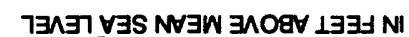
7ตนสำ

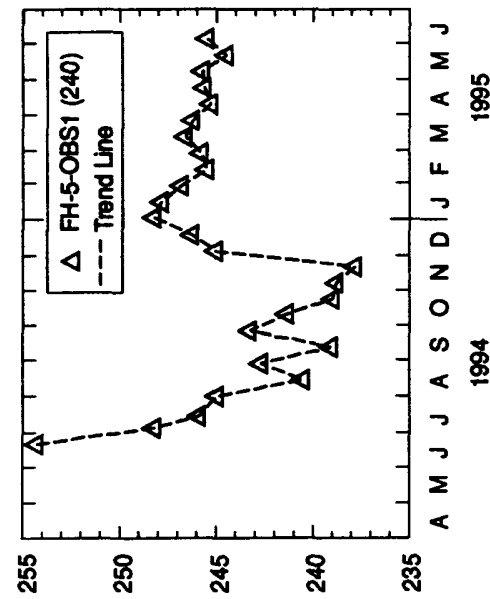

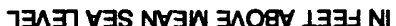
าำรัษ
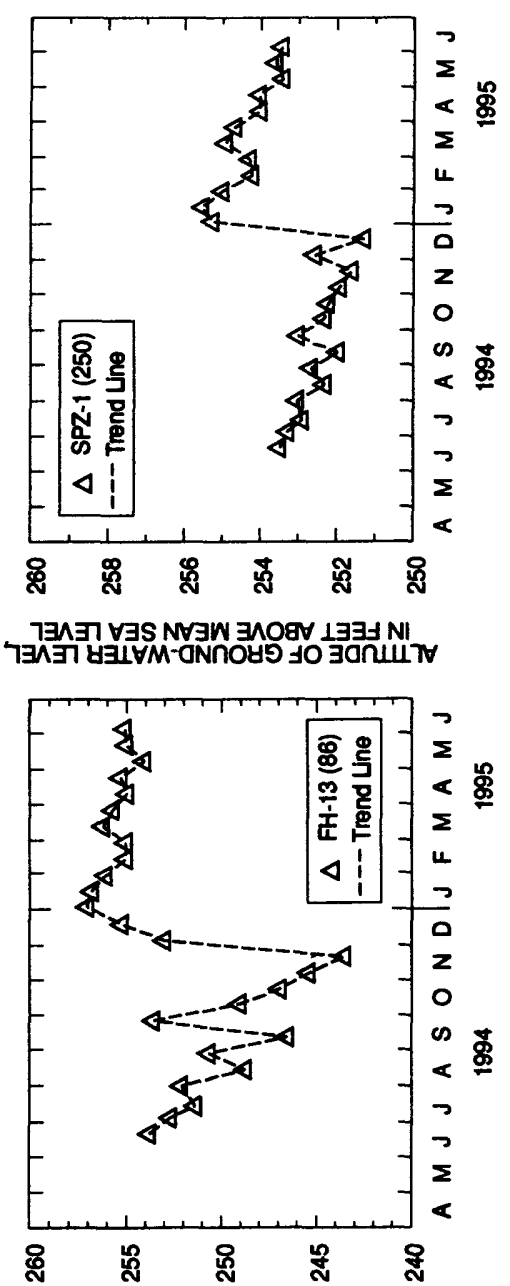

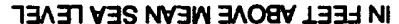
า
7ㅋㅋำ

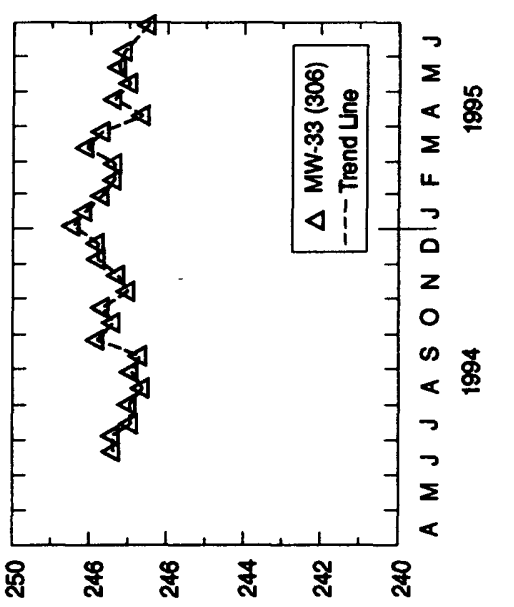

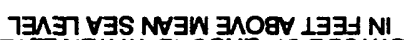
ำง ำ

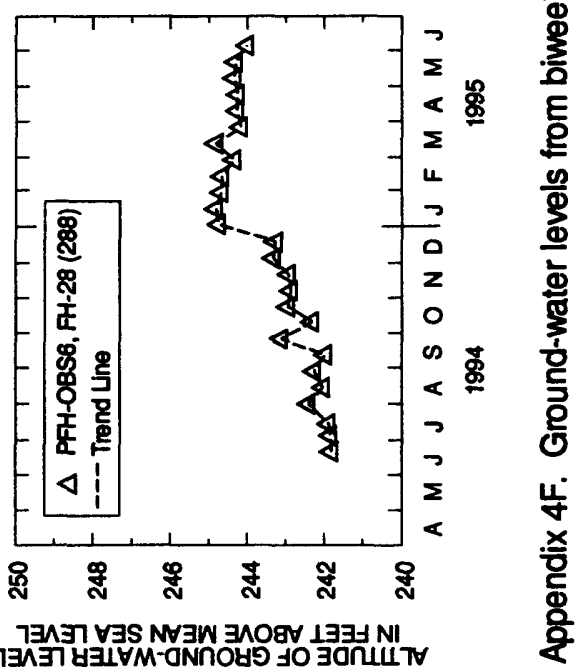




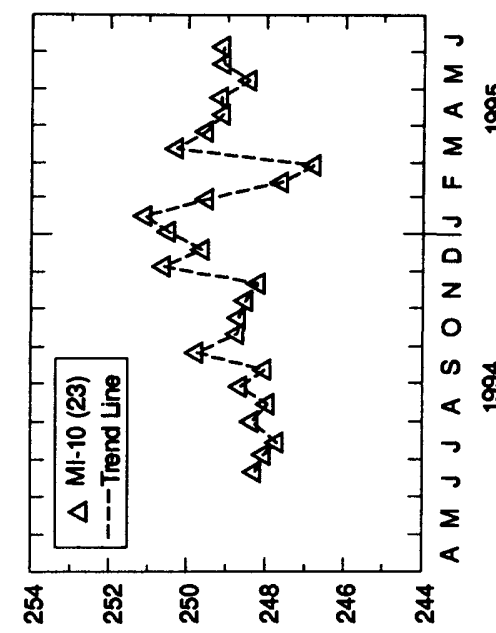

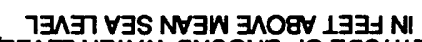
ㅋา

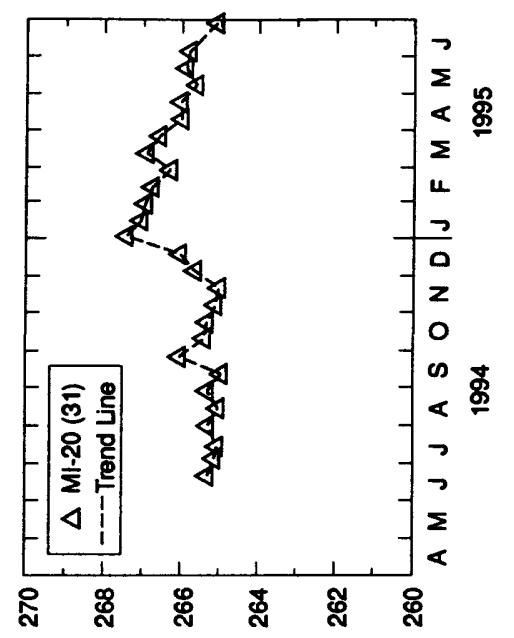

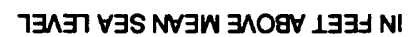
ᄀ

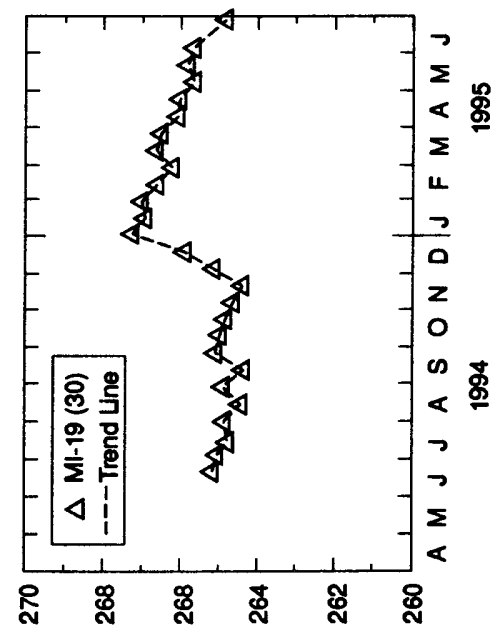

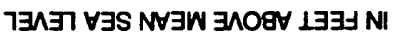
ᄀ

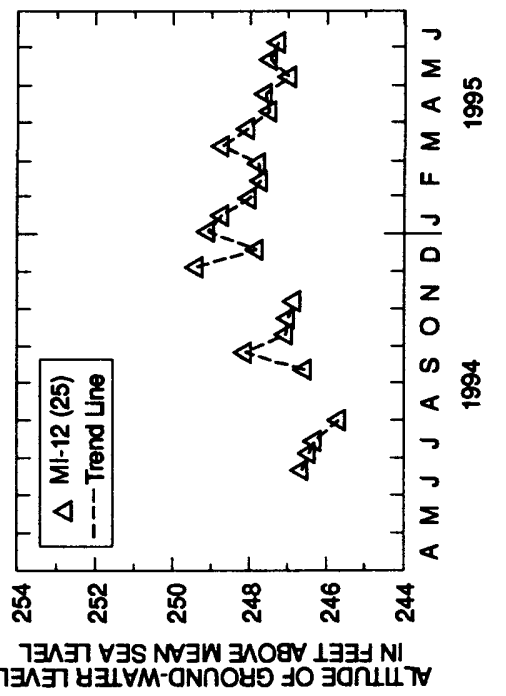

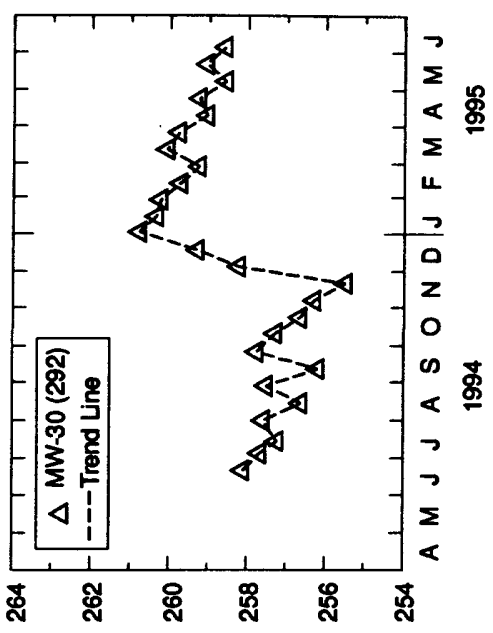

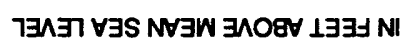

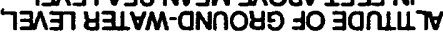
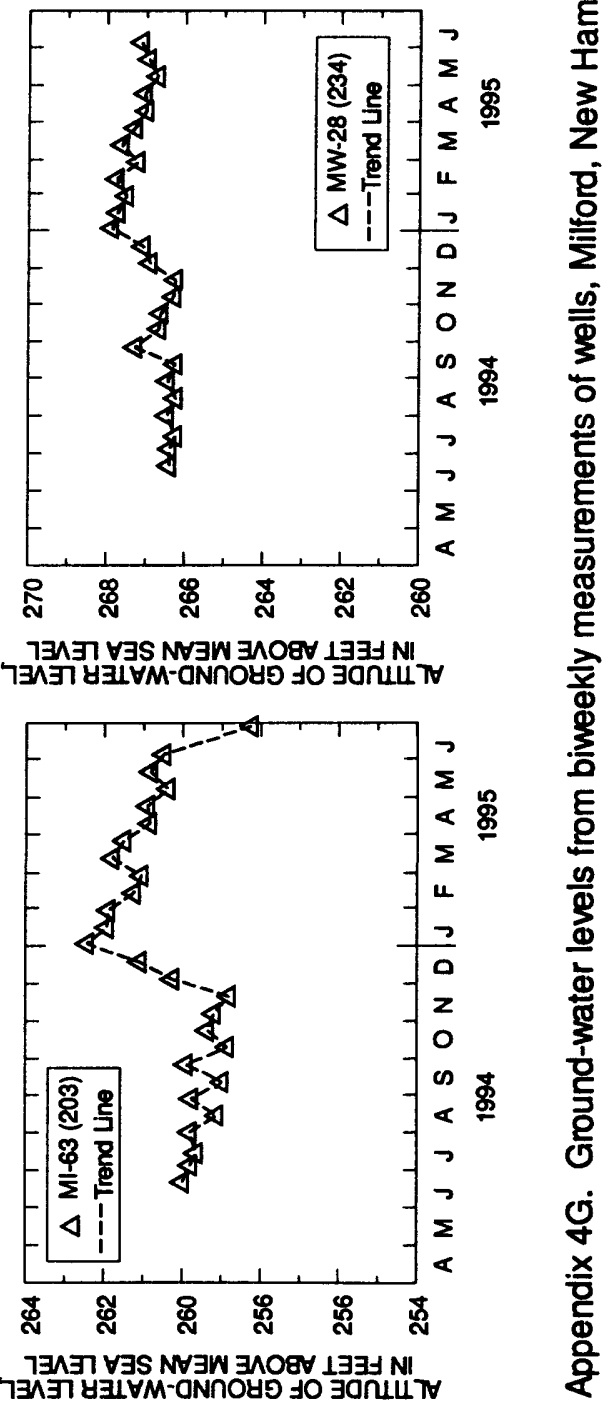


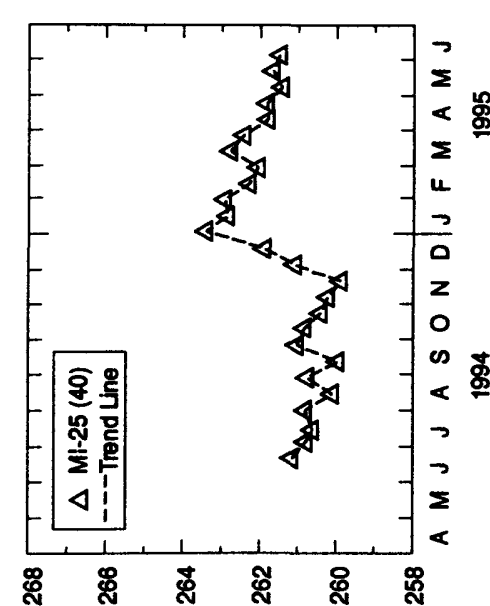

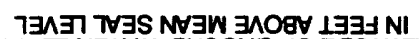

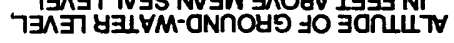
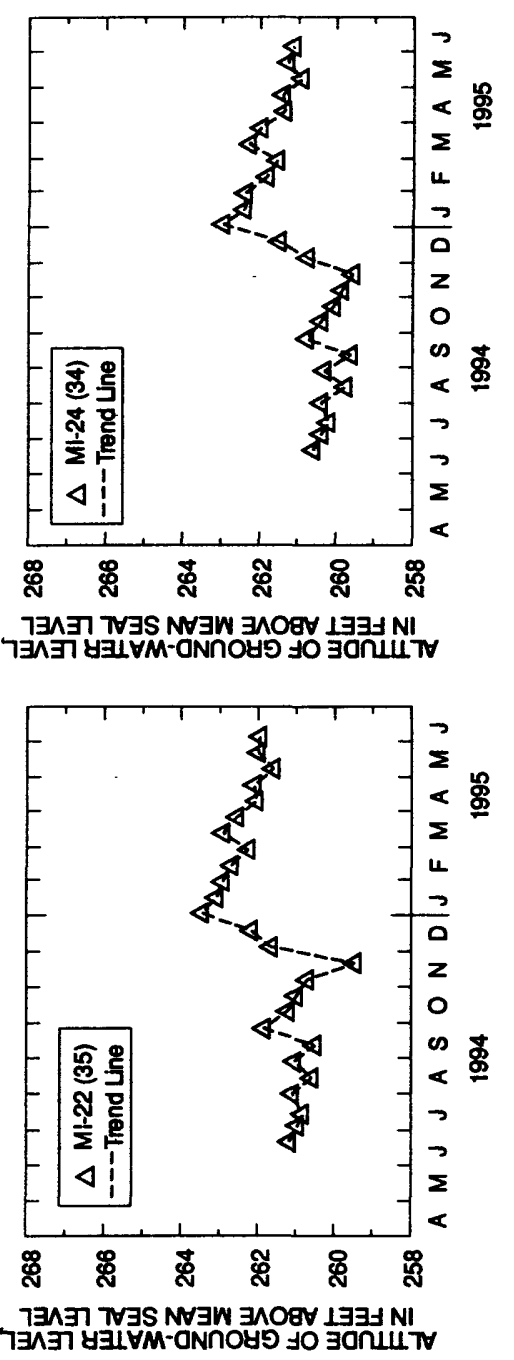

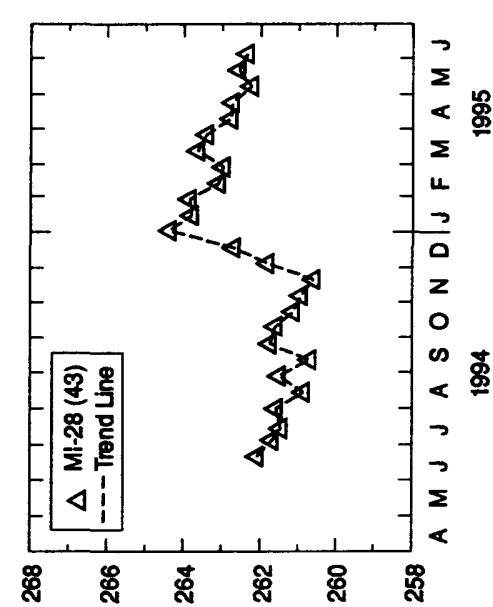

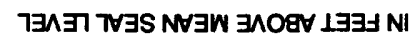
ר
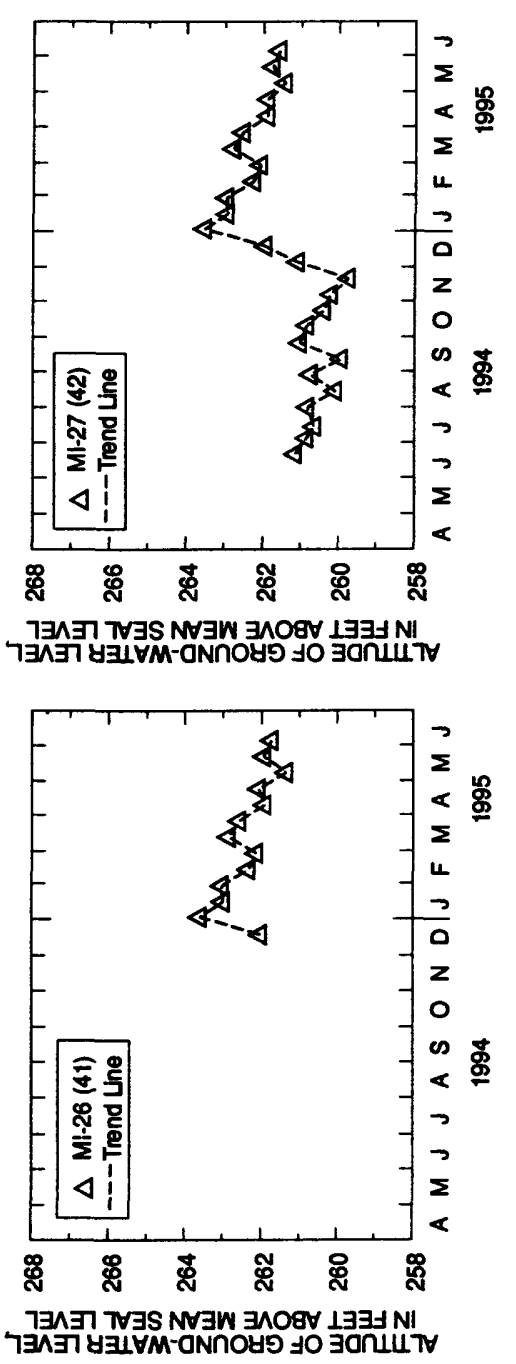

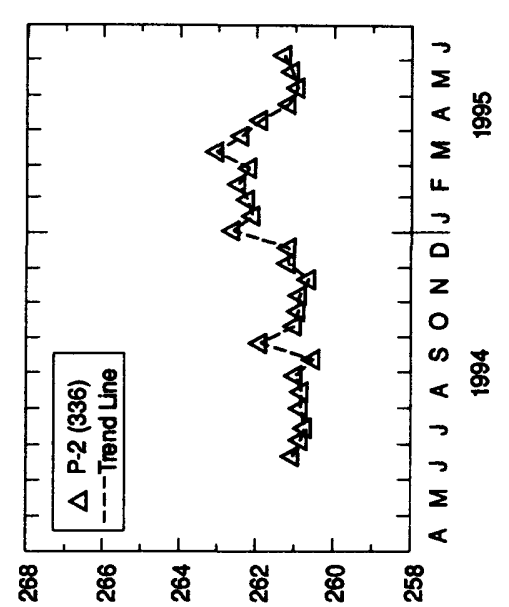

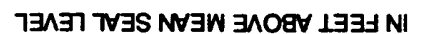
ר
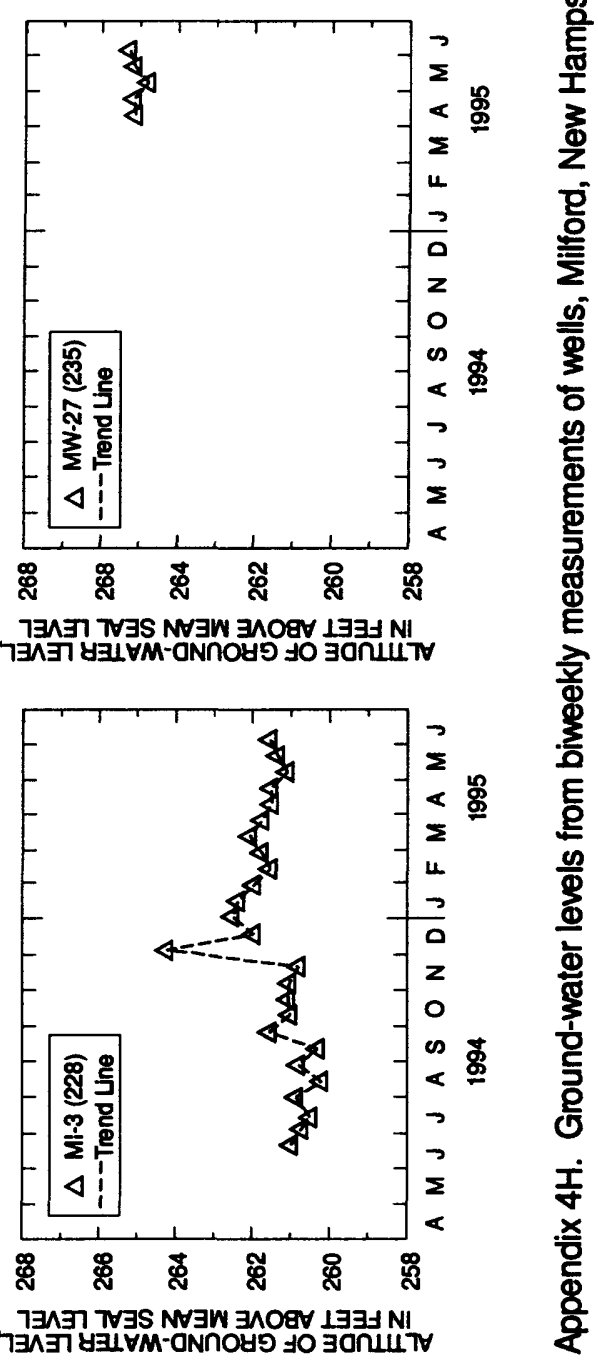
APPENDIX 5 


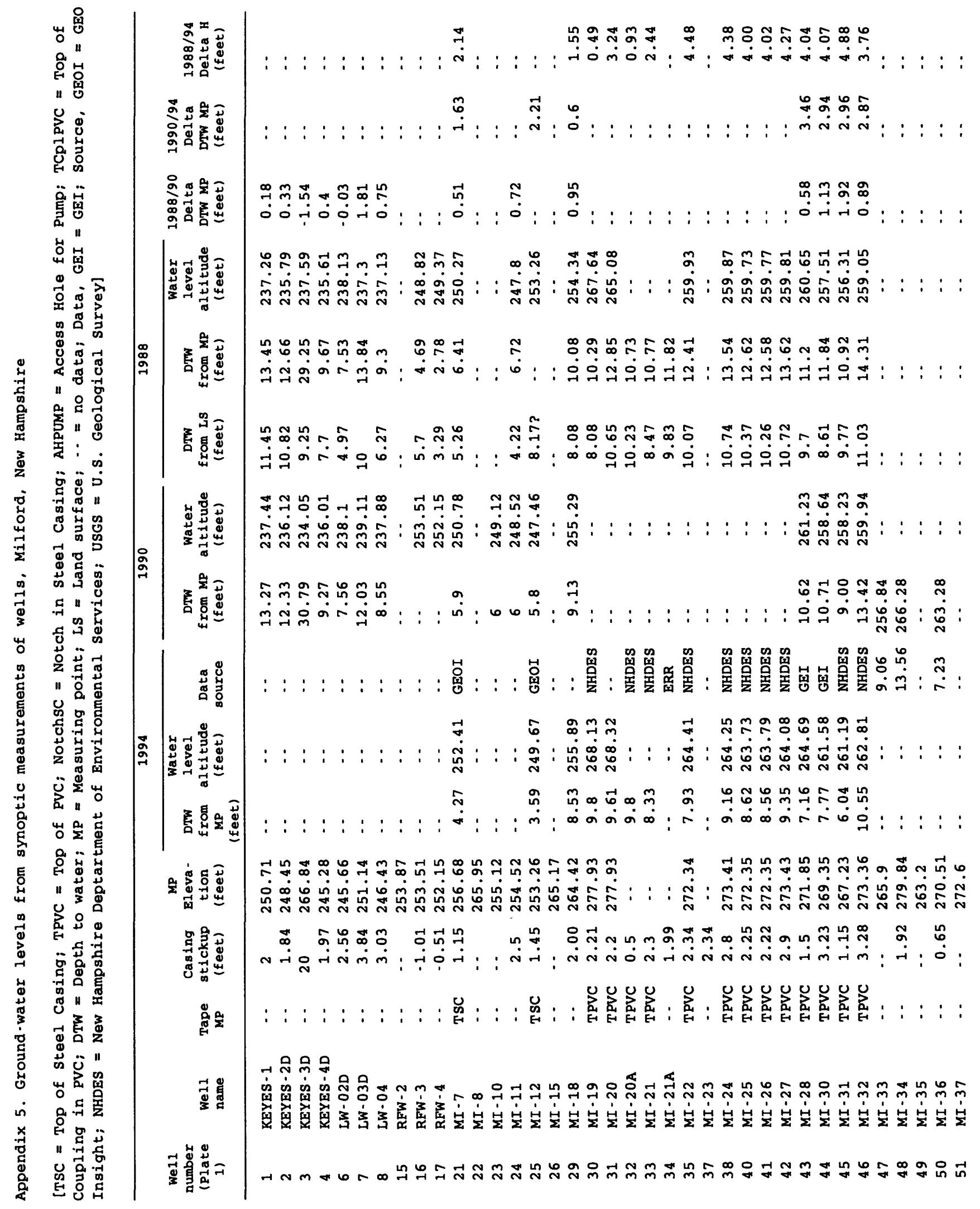




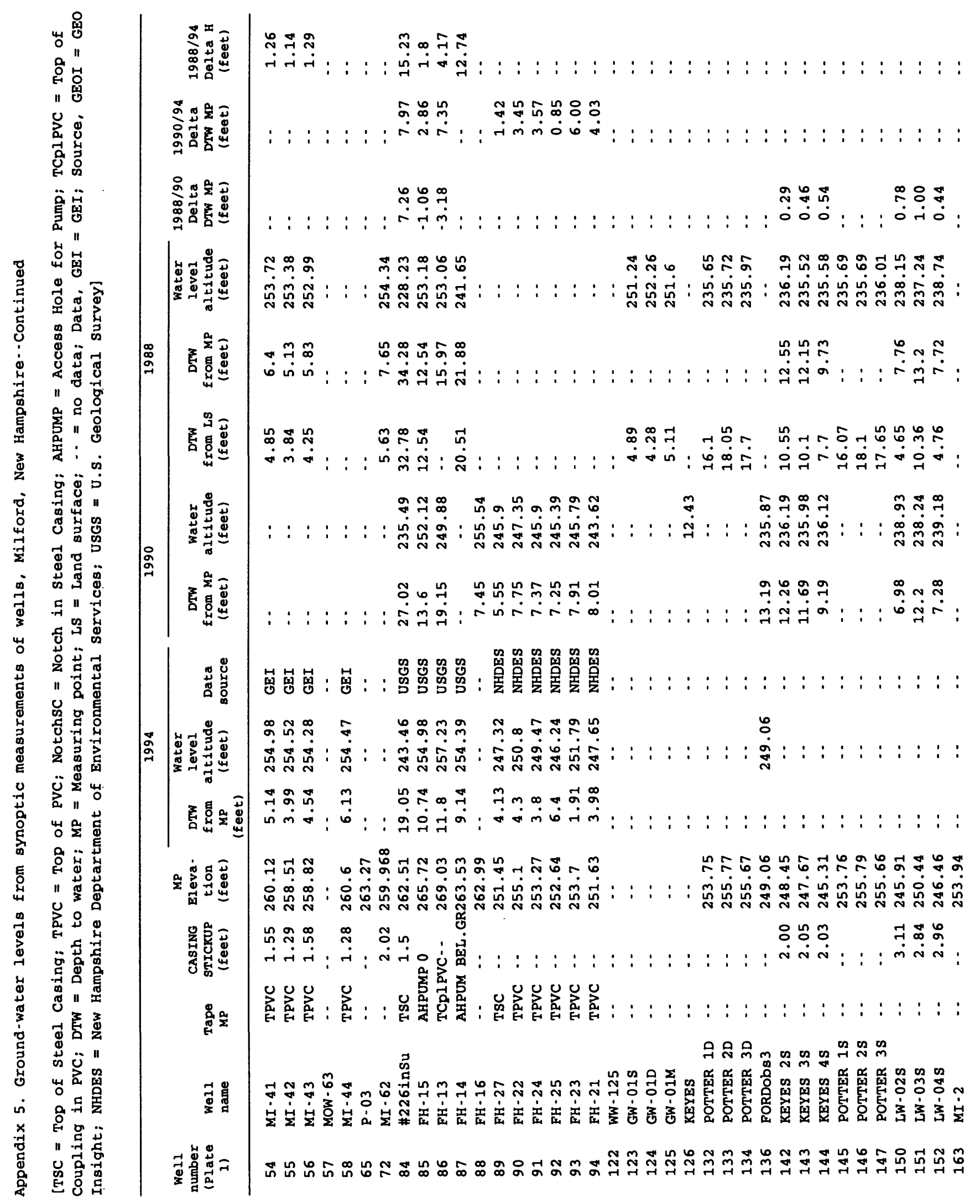




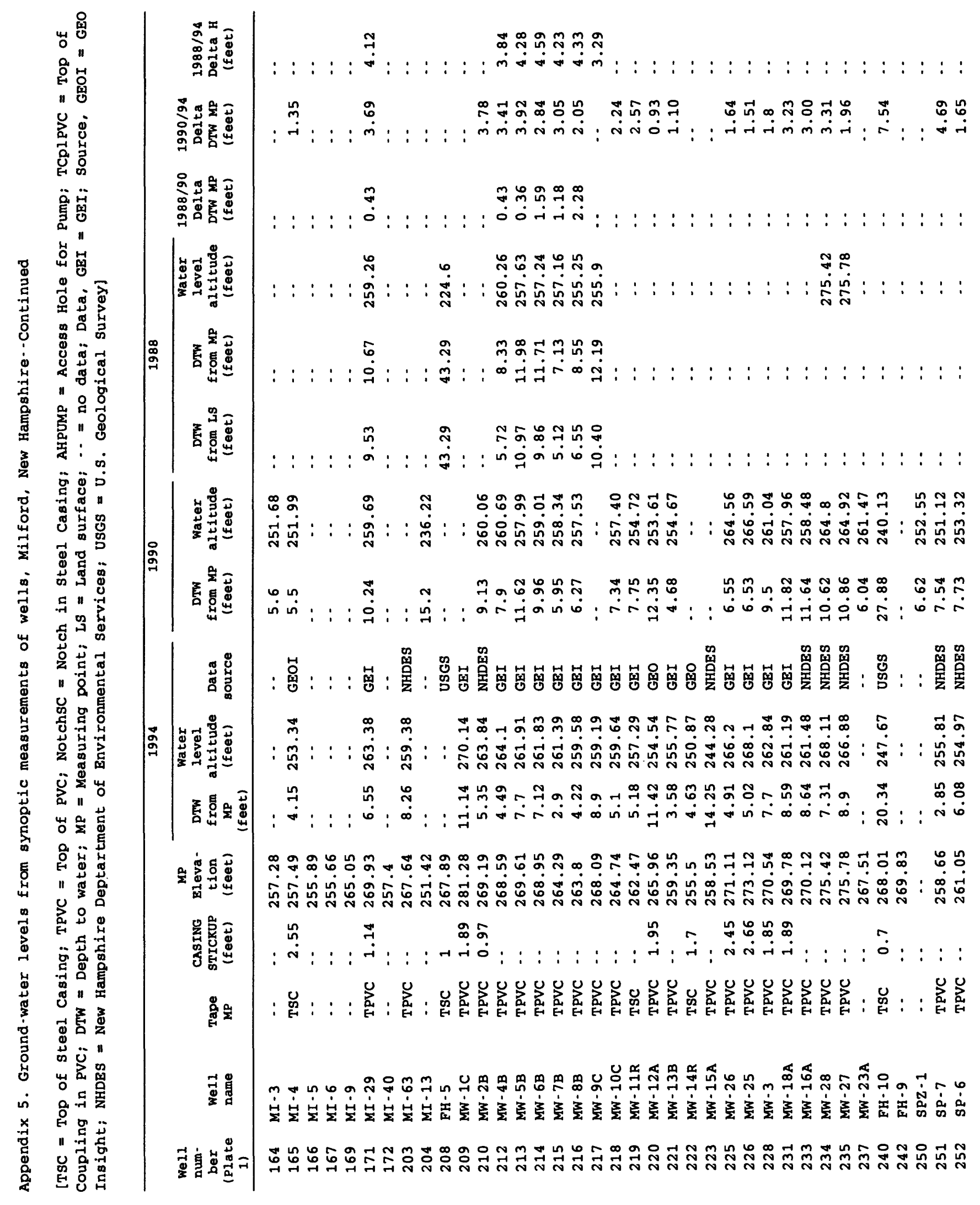




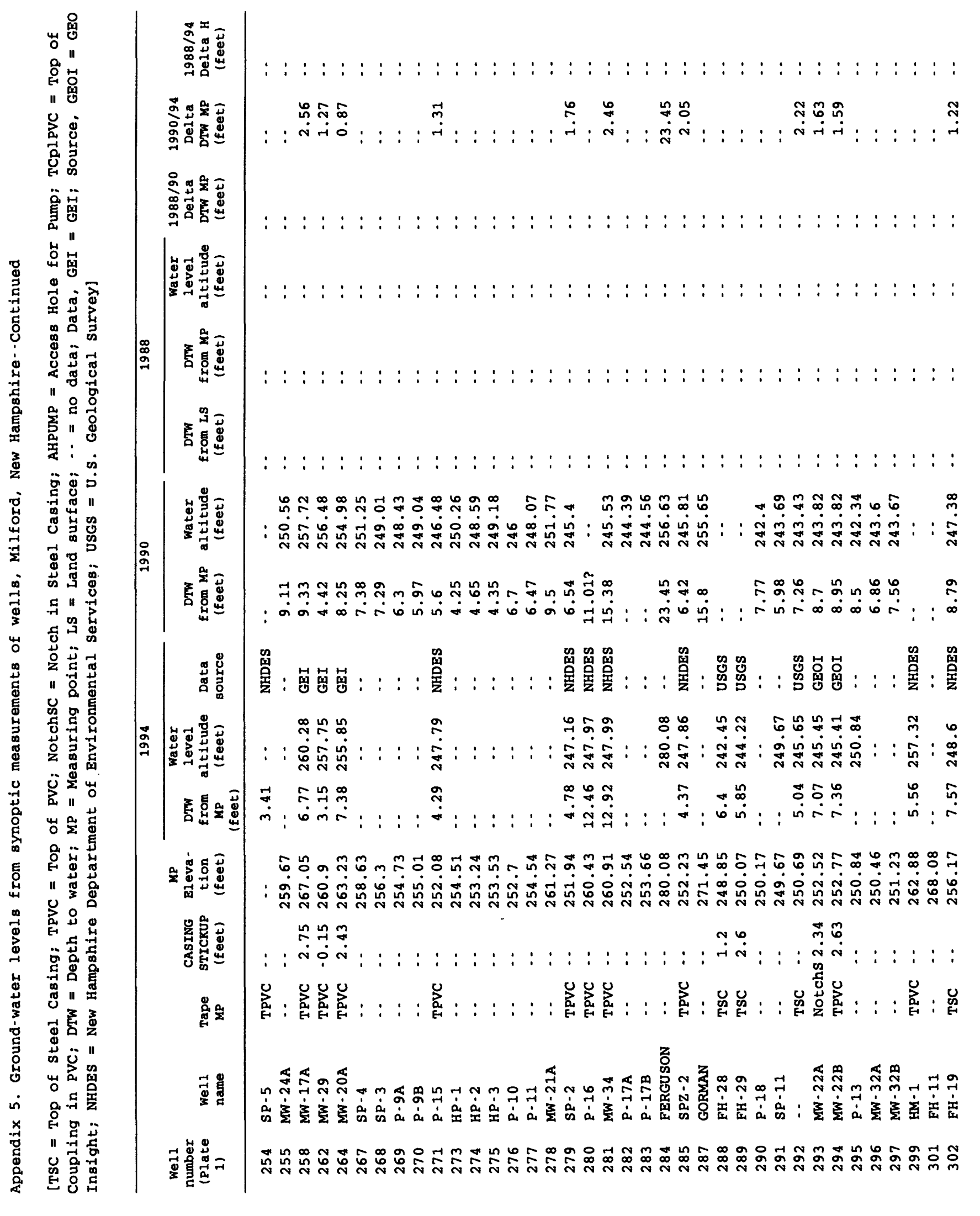




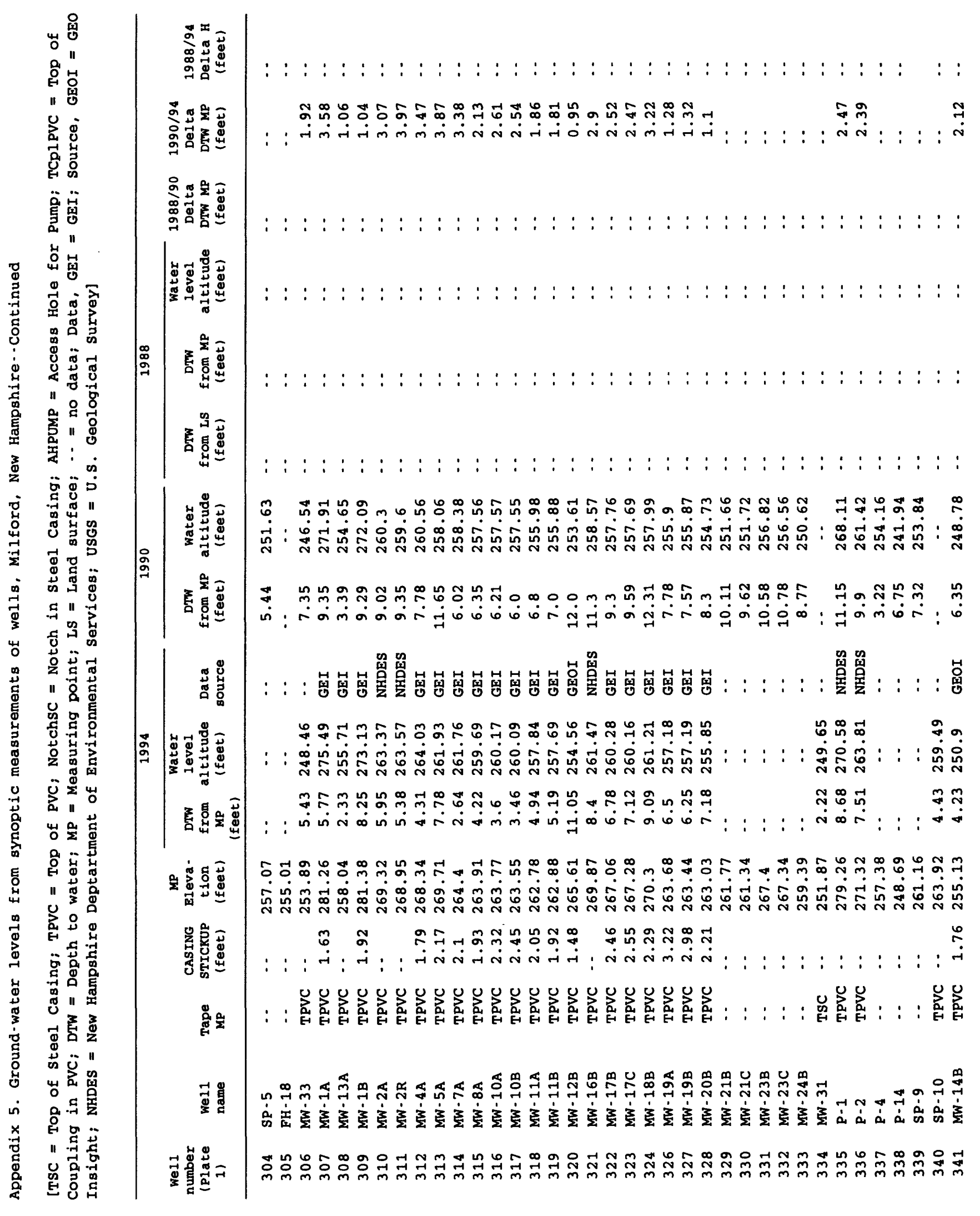




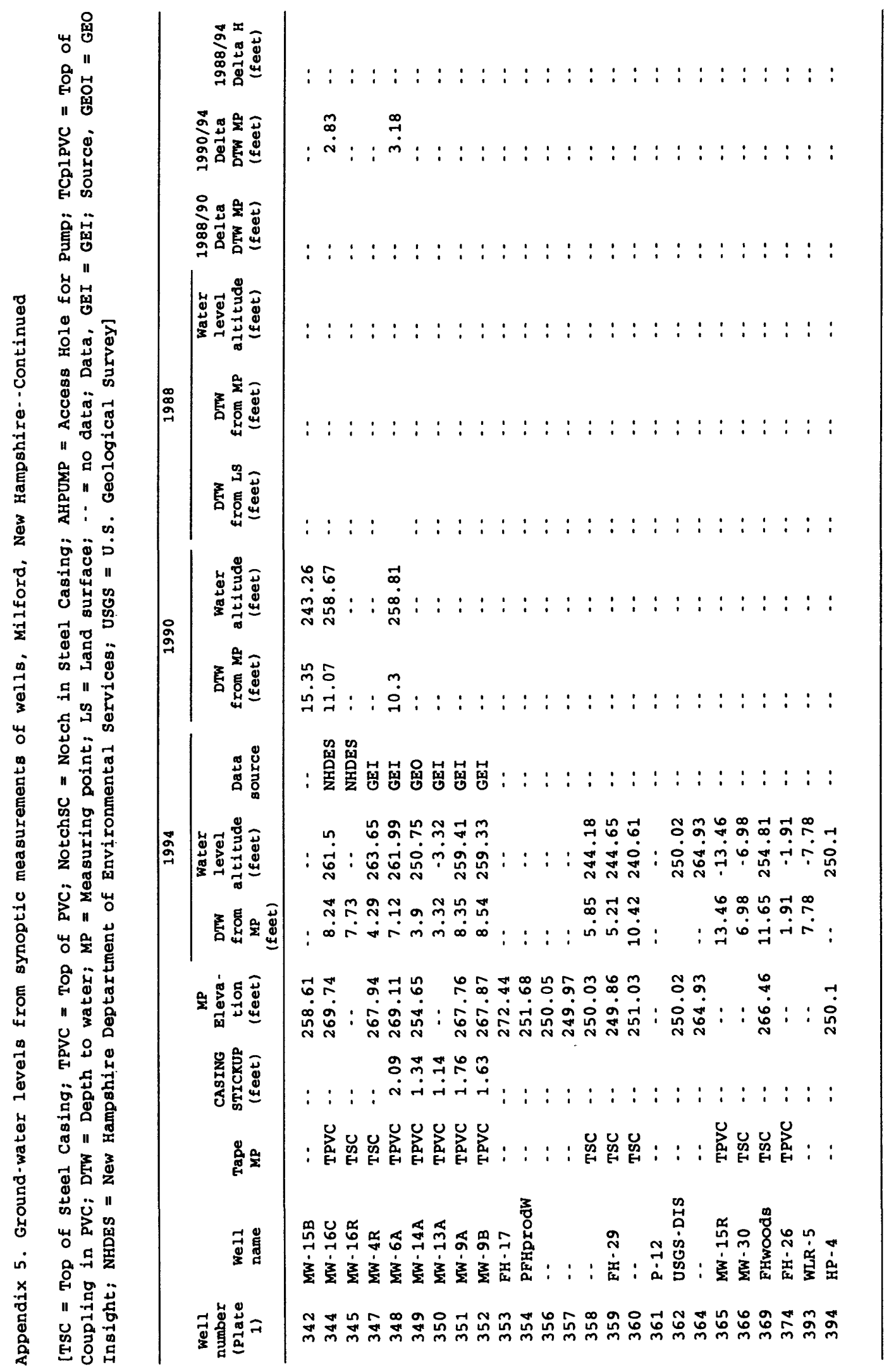


APPENDIX 6 
Appendix 6. Surface-water and ground-water hydraulic gradients determined from wells in the glacialdrift aquifer and staff gages on the Souhegan River, Milford, New Hampshire

[mm/dd/yr, month day year; P-1 (335), well name and (number); WLR-1 (SG), staff gage at or near well location; units in feet/feet, difference in head divided by horizontal distance; negative values indicate river stage is greater than ground-water level; BDRK, bedrock; -., no data; monitoring well locations shown on figure 7]

Hydraulic gradients between monitoring wells and staff gages (feet/feet)

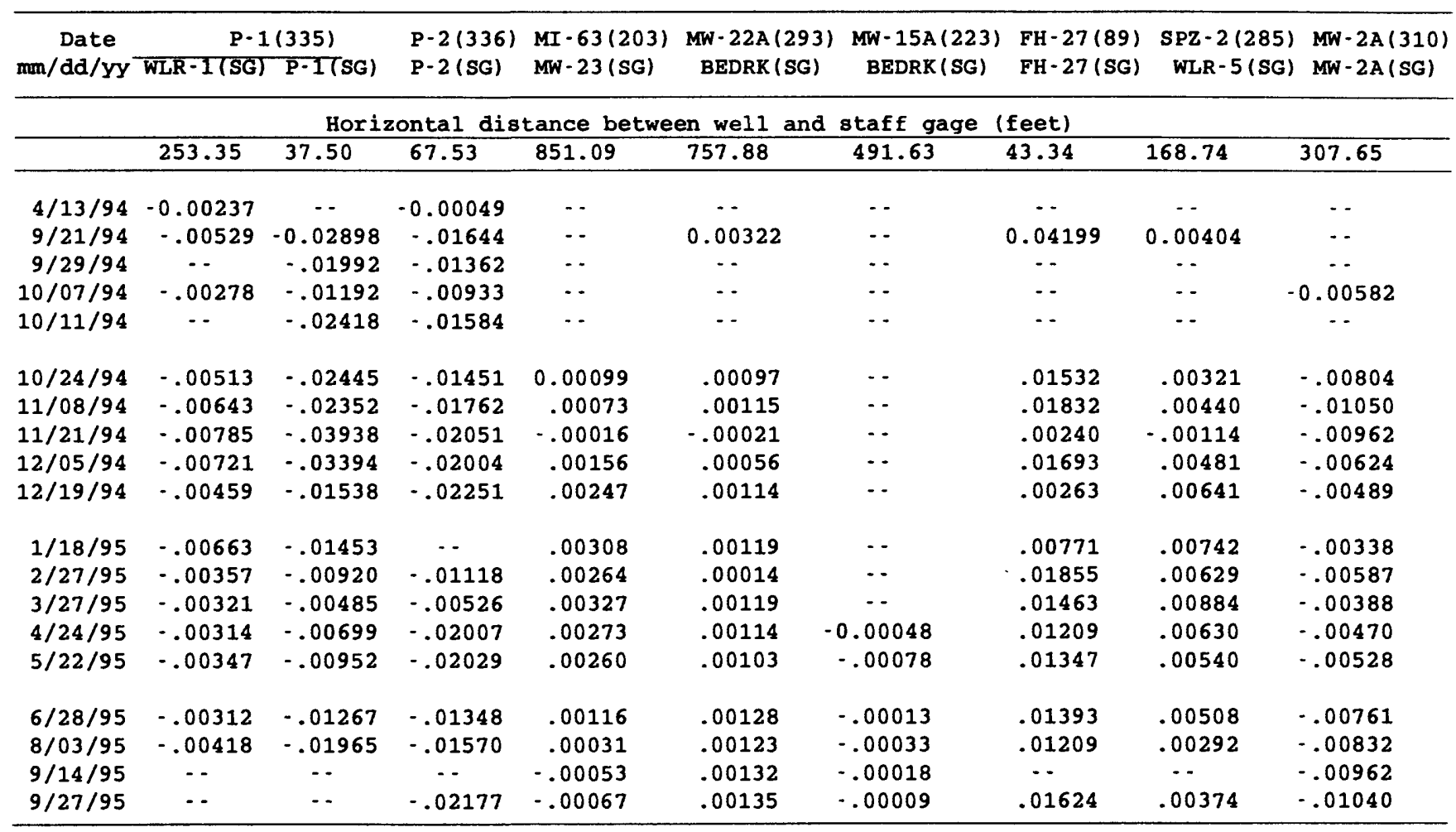

